\title{
Historical and Archaeological Investigations at the Site of Rivercenter Mall (Las Tiendas), San Antonio, Texas
}

Anne A. Fox

Center for Archaeological Research

Marcie Renner

Center for Archaeological Research

Follow this and additional works at: https://scholarworks.sfasu.edu/ita

Part of the American Material Culture Commons, Archaeological Anthropology Commons, Environmental Studies Commons, Other American Studies Commons, Other Arts and Humanities Commons, Other History of Art, Architecture, and Archaeology Commons, and the United States History Commons

Tell us how this article helped you.

This Article is brought to you for free and open access by the Center for Regional Heritage Research at SFA ScholarWorks. It has been accepted for inclusion in Index of Texas Archaeology: Open Access Gray Literature from the Lone Star State by an authorized editor of SFA ScholarWorks. For more information, please contact cdsscholarworks@sfasu.edu. 


\section{Historical and Archaeological Investigations at the Site of Rivercenter Mall (Las Tiendas), San Antonio, Texas}

\section{Creative Commons License}

\section{(c) (1) \&}

This work is licensed under a Creative Commons Attribution-NonCommercial 4.0 International License 


\section{Historical and Archaeological Investigations at the Site of Rivercenter Mall (Las Tiendas), San Antonio, Texas}

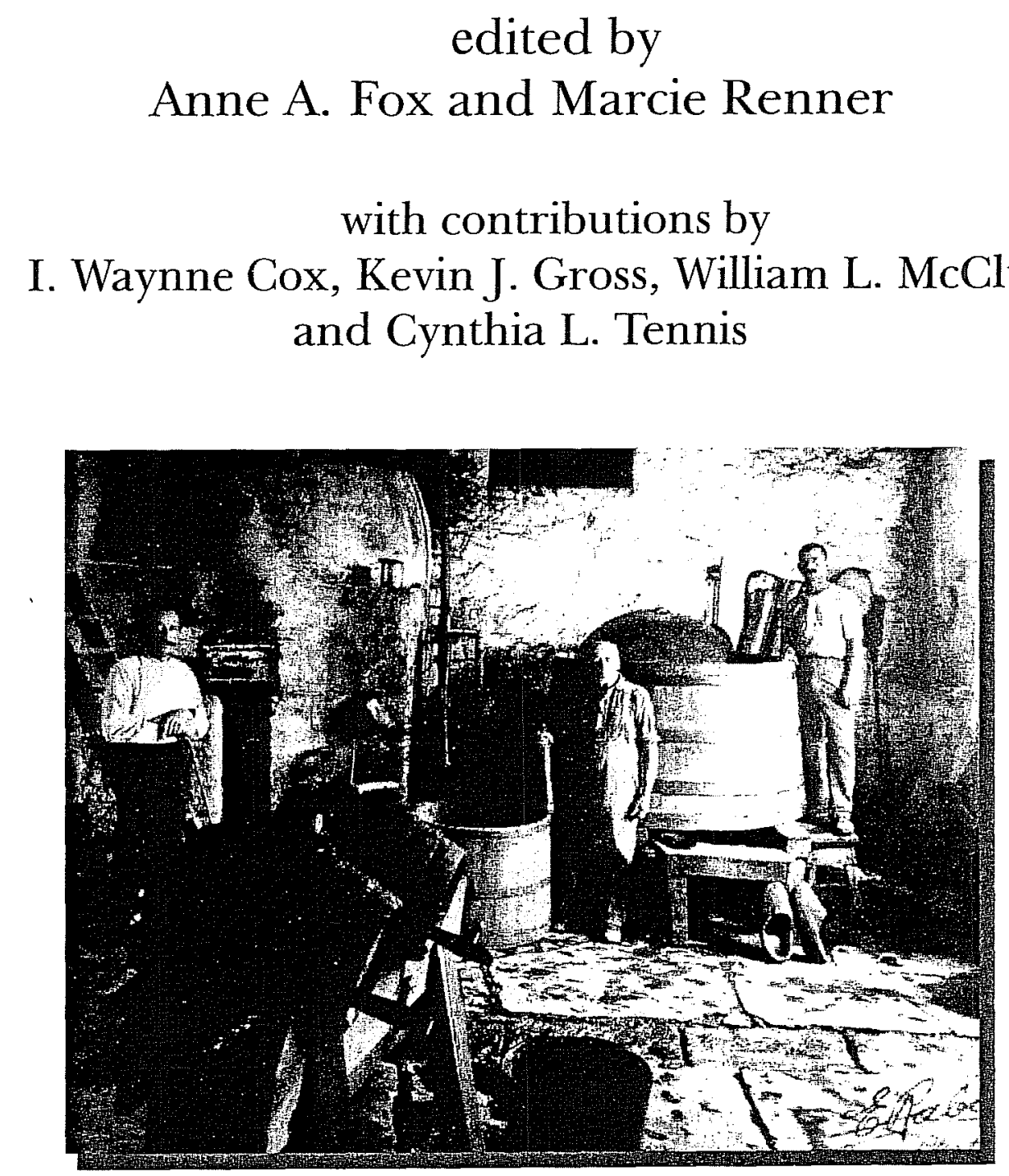

Archaeological Survey Report, No. 270

Center for Archaeological Research

The University of Texas at San Antonio 1999 



\title{
Historical and Archaeological Investigations at the Site of Rivercenter Mall (Las Tiendas), San Antonio, Texas
}

\author{
edited by Anne A. Fox and Marcie Renner \\ with contributions by \\ I. Waynne Cox, Kevin J. Gross, William L. McClure, \\ and Cynthia L. Tennis
}

Robert J. Hard, Jack D. Eaton, and Thomas R. Hester Prinicipal Investigators

Texas Antiquities Permit No. 433

Ccopyright 1999

Center for Archaeological Research

The University of Texas at San Antonio

Archaeological Survey Report, No. 270 
The following information is provided in accordance with the General Rules of Practice and Procedure, Chapter 41.11 (Investigative Reports), Texas Antiquities Committee:

1. Type of investigation: Testing and mitigation

2. Project name: Rivercenter Mall (Las Tiendas)

3. County: Bexar

4. Principal investigators: Robert J. Hard, Jack D. Eaton, and Thomas R. Hester

5. Name and location of sponsoring agency: City of San Antonio, P.O. Box 83996, San Antonio, Texas

6. Texas Antiquities Permit No.: 433

7. Published by the Center for Archaeological Research, The University of Texas at San Antonio, 6900 N. Loop 1604 W., San Antonio, Texas 78249-0658, 1999

A list of publications offered by the Center for Archaeological Research is available. Call (210) 458-4378; write to the Center for Archaeological Research, The University of Texas at San Antonio, 6900 N. Loop 1604 W., San Antonio, Texas 78249-0658; e-mail to car@lonestar.utsa.edu; or visit CAR's web site at http://www.csbs.utsa.edu/research/car/index.htm. 


\begin{abstract}
From October 1984 to July 1985, the Center for Archaeological Research of The University of Texas at San Antonio conducted testing and mitigation on a three-block area intended to become a shopping center in downtown San Antonio. The project was bounded on the north by Crockett Street, on the east by Bowie Street, on the south by Commerce Street, and on the west by Bonham Street. Information on the mapping and test excavations at 12 historic sites and total excavation of a well and a number of privies is reported in this publication. Analysis and description of the artifacts recovered and discussion of the architecture of the project area are also included.

This was the first large-scale archaeological project conducted in the downtown area, involving excavation of deep deposits of artifacts related to the late nineteenth century. Techniques evolved during this project for historical research, oral history interviews, and excavation of wells and privies would prove essential to the planning of similar projects elsewhere.
\end{abstract}




\section{Contents}

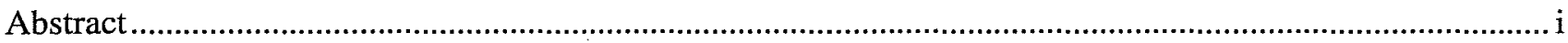

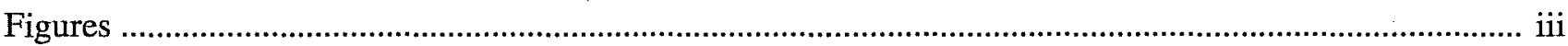

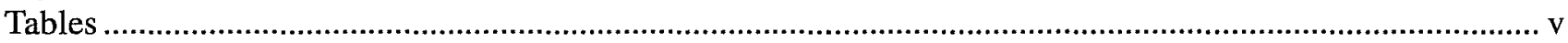

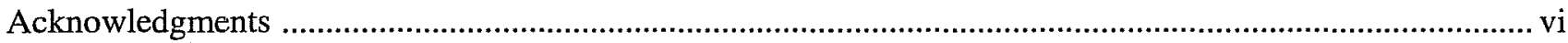

Part I: Project Background

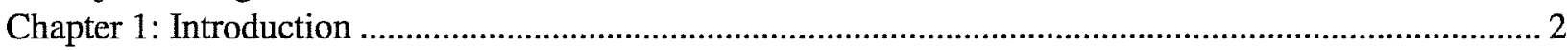

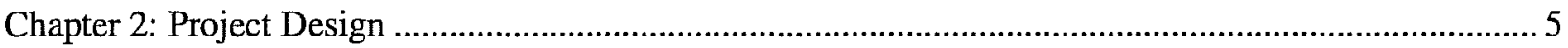

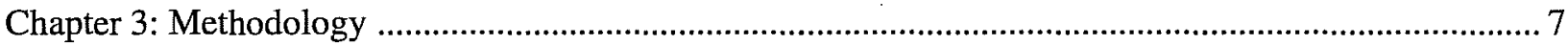

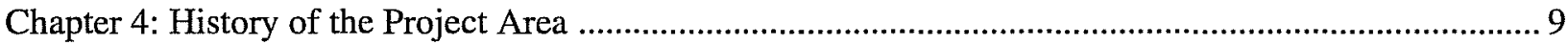

Part II: The Sites

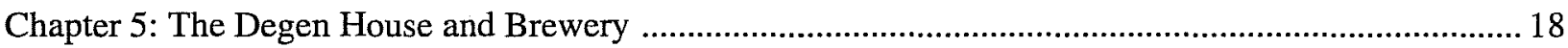

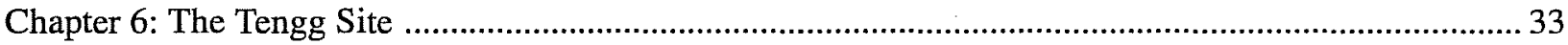

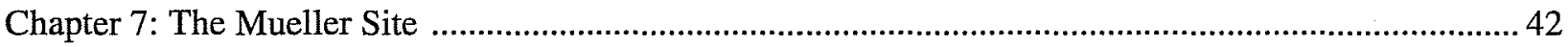

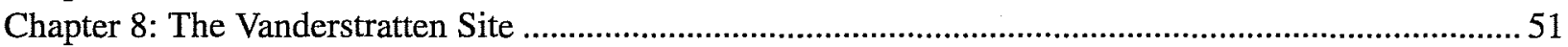

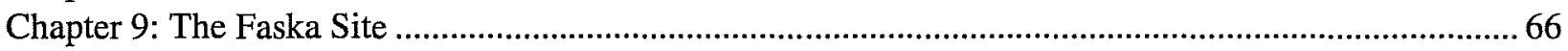

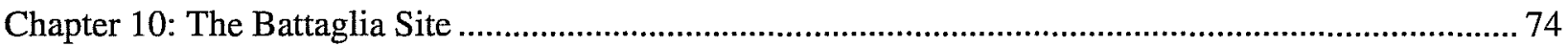

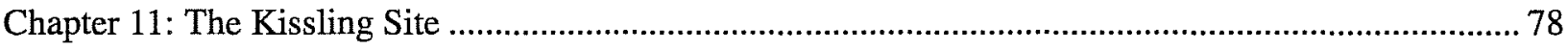

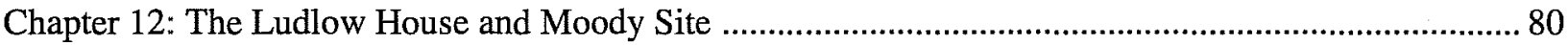

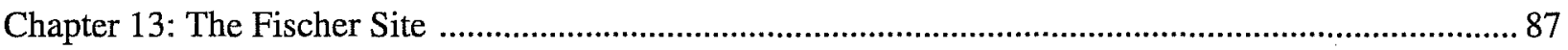

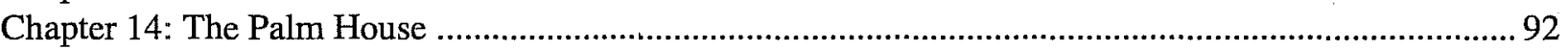

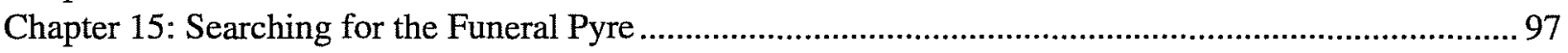

Chapter 16: Moving the Fairmount Hotel ........................................................................................ 103

Part III: Conclusions

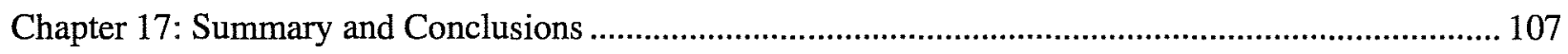

Part IV: References and Appendixes

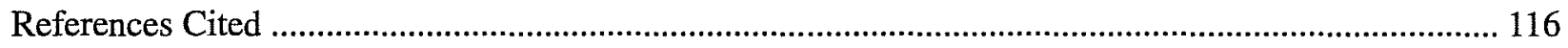

Appendix A: The Vertebrates of Las Tiendas

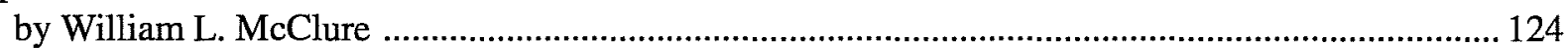

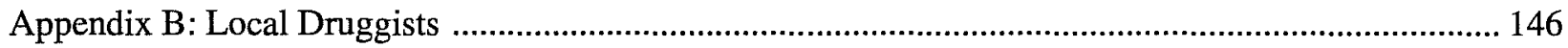

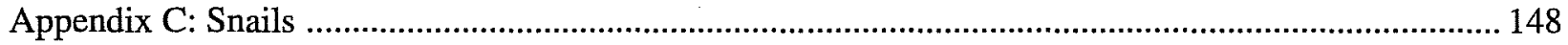

An Early Urban Record of Opeas pyrgula in San Antonio, Texas

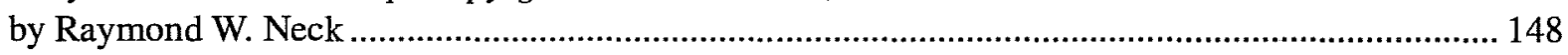

Appendix D: Skeletal Remains from the Funeral Pyre Area

by David M. Glassman, Ph.D. 


\section{Figures}

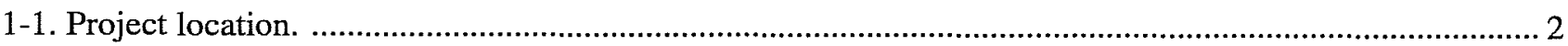

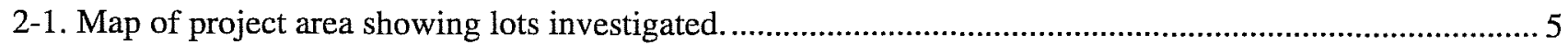

3-1. Structures and excavations on NCB 1010

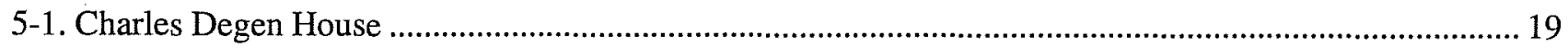

5-2. Location map of Degen and Mueller sites. ………….................................................................. 19

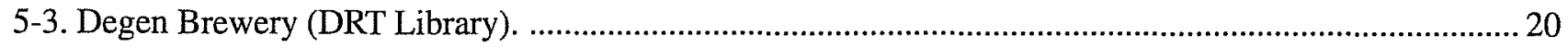

5-4. Interior basement of Degen Brewery ca. 1890 (DRT Library). …………………................................... 20

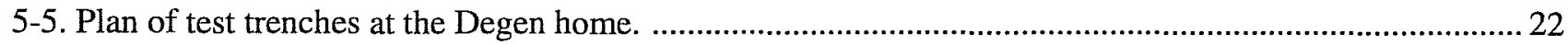

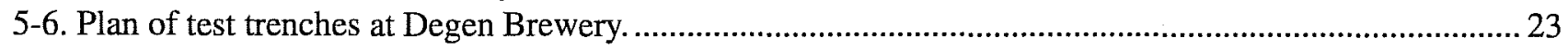

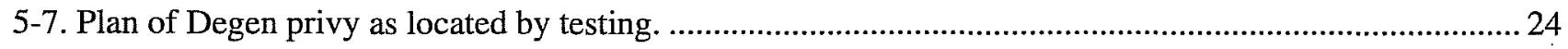

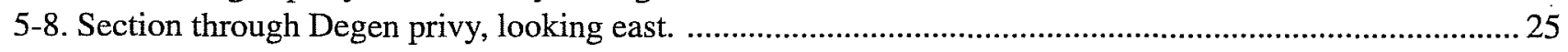

5-9. Chamber pot from Degen Privy ................................................................................................... 30

5-10. Sample of bottles from the Degen Privy. ............................................................................................... 31

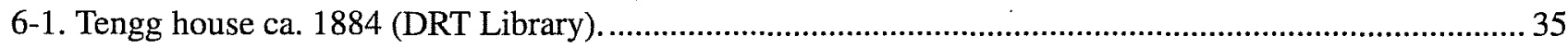

6-2. Tengg house with second floor addition (DRT Library), ....................................................................... 36

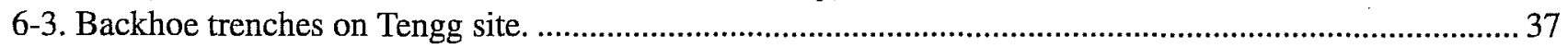

6-4. Portions of Tengg house exposed in trenches. .................................................................................... 38

6-5. Excavations at the back of the Tengg lot........................................................................................ 39

7-1. The Mueller house at 247 Blum Street ca. 1900 (DRT Library). ............................................................. 43

7-2. Test excavations at the Mueller house site. ....................................................................................... 44

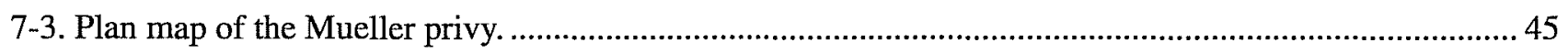

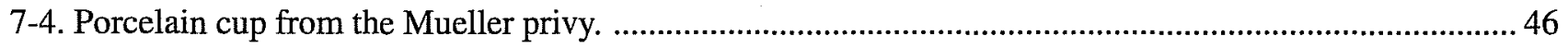

7-5. Semiporcelain plate from the Mueller privy. .................................................................................... 46

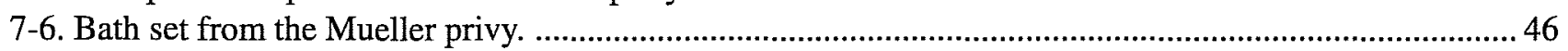

7-7. Representative bottles from the Mueller privy. ....................................................................................... 48

7-8. Drinking goblets from the Mueller privy. ......................................................................................... 48

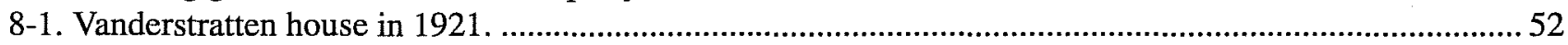

8-2. Location of Vanderstratten house on west end of NCB 166. ................................................................. 53

8-3. Plan (top) and profile (bottom) of Vanderstratten well. ........................................................................... 54

8-4. Porcelain dishes from the Vanderstratten well.

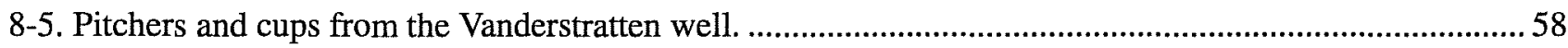

8-6. Ceramic spittoons from the Vanderstratten well ................................................................................... 58

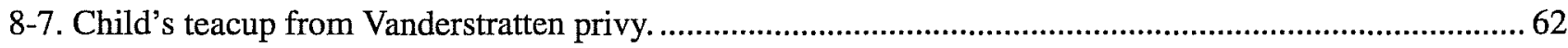

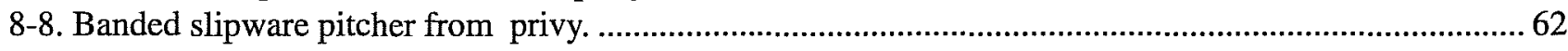

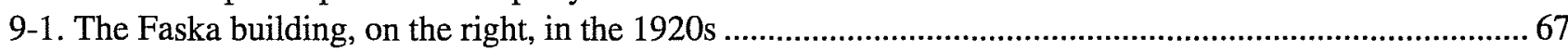

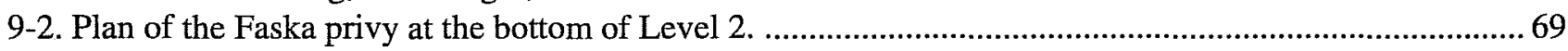

10-1. Plan of the back fifteen feet of the Battaglia lot. ................................................................................. 75

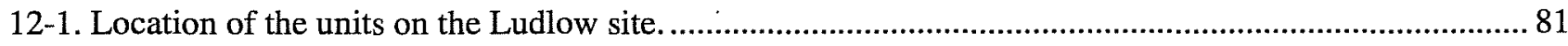

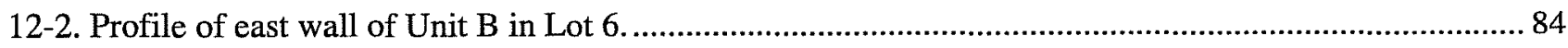

13-1. Location of the Fischer and Palm sites and the Fairmount Hotel. ........................................................ 87

13-2. East profile of Trench 1 across back of Fischer lot. .............................................................................. 88

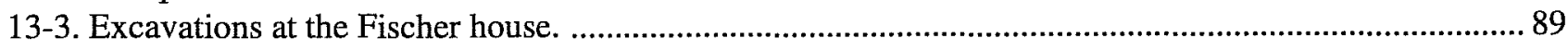

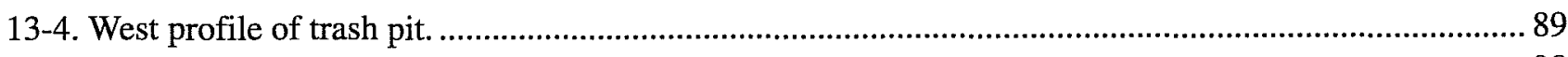

13-5. Small artifacts from the trash pit. ..................................................................................................... 90

13-6. Bottles and ceramics from the trash pit.............................................................................................. 91

14-1. Trench over front wall of the Palm house. ............................................................................................ 93 


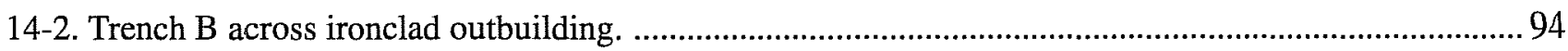

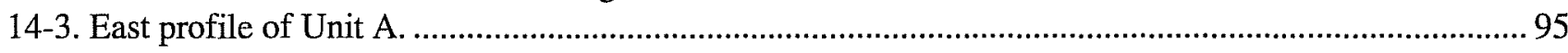

A-1. Chart for estimating live weight of chickens from the length of certain long bone ........................... 125

A-2. Estimated live weights of chickens from the Mueller Site .............................................................. 129

A-3. Estimated live weights of chickens from the Faska Site ............................................................... 132

A-4. Estimated live weights of chickens from the Vanderstratton Site ................................................. 141 


\section{Tables}

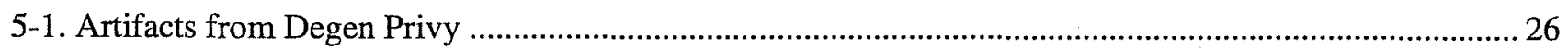

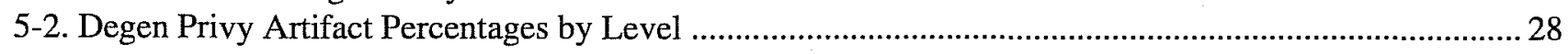

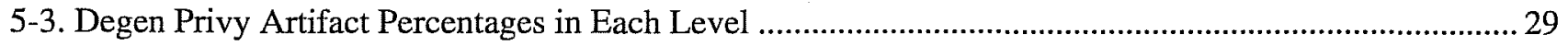

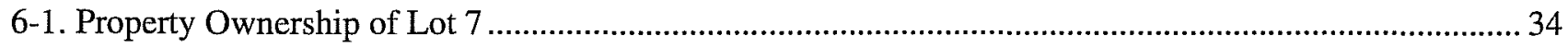

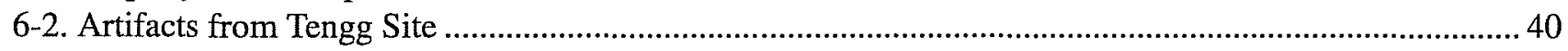

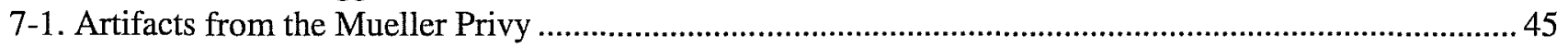

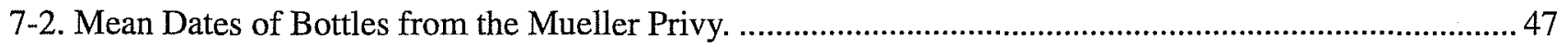

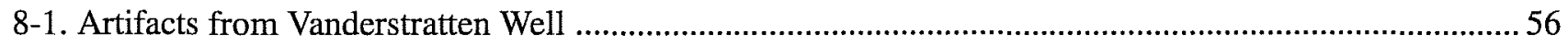

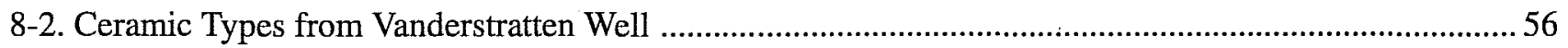

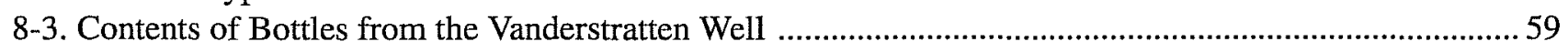

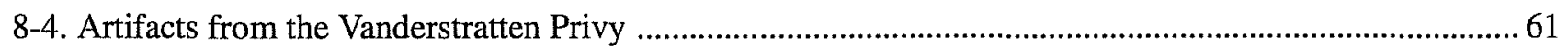

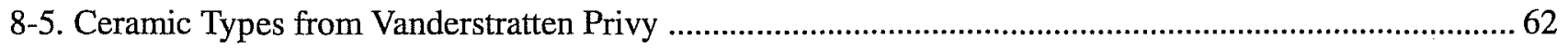

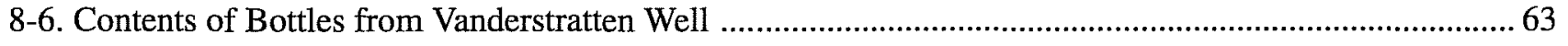

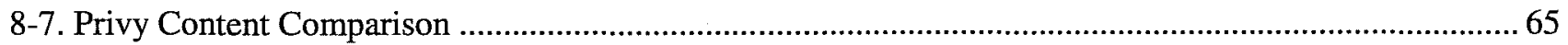

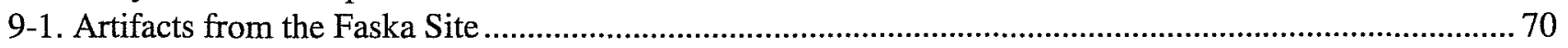

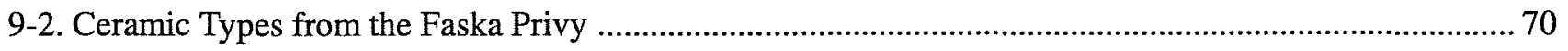

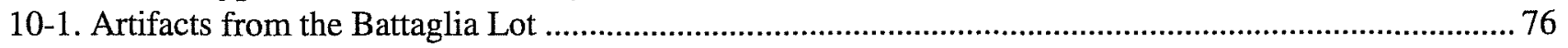

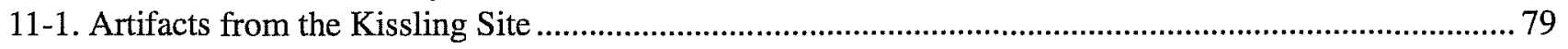

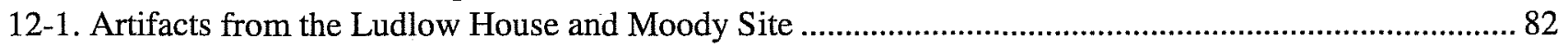

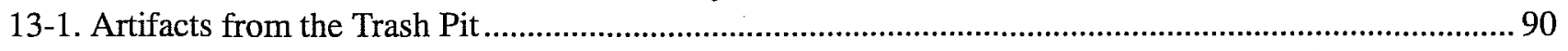

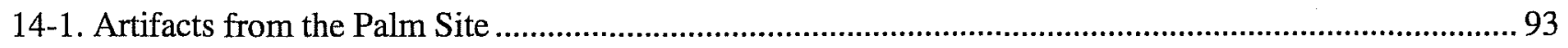

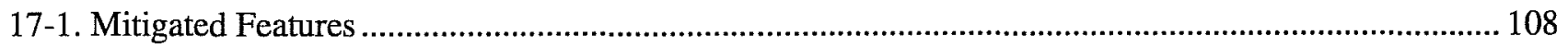

17-2. Stone House Construction in San Antonio, 1850-1890 .......................................................... 113

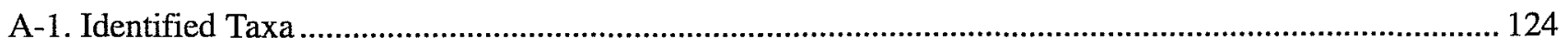

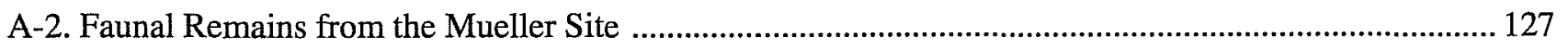

A-3. Faunal Remains from the Faska Site. .................................................................................. 131

A-4. Faunal Remains from the Vanderstratten Privy ........................................................................ 134

A-5. Faunal Remains from the Vanderstratten Well .................................................................................. 137

A-6. Faunal Remains from the Vanderstratten Yard ................................................................................... 140 


\section{Acknowledgments}

A project of this size requires the cooperation of many people. We are grateful for the help and cooperation of Frank Perry, special projects coordinator for the San Antonio City Manager's Office, and Pat Osborne, historic preservation officer for the city at that time. The advice and guidance of Dr. LaVerne Herrington, director of resource conservation at the Texas Historical Commission at that time, and Robert Fink, chief of the western division of Project Review at the Advisory Council on Historic Preservation were also much appreciated. Carol Wyant of Williams Realty served as liason with the Allied Stores/Williams Realty developers. A.E. Sanii, manager for the Southwest Region of Day and Zimmerman, the project managers was helpful in handling various problems.

The authors wish to thank Dr. Thomas R. Hester and Jack Eaton, who at that time were director and associate director of the Center for Archaeological Research, for serving as principal investigators and helping to manipulate a rather complex project through to a successful conclusion. The principal crew members who faithfully served throughout the project, in fair weather and foul, deserve special credit. Waynne Cox persevered as field director through the entire time, as well as doing a major part of the historical and archival research. He kept a detailed record of all the fieldwork, who was there, what we were doing, and why, which makes for interesting reading even today. Ray Smith did yoeman duty as recorder and commentator on the construction and architecture. Without his meticulous drawings and notes, much of the detail on the architecture could not have been written. Ralph Snavely became our backhoe operator, spending many hours carefully uncovering structures and digging test trenches. Beth Craig recorded the work with her camera, producing fine, clear pictures of the features we uncovered. Lynn Highley ran the laboratory work for the project, overseeing the washing, cataloging, and record keeping. Roger Johnson wrote the history of the Degen family. Kay Hindes did oral history interviews and archival research.

However, the people who made the whole project possible should have a generous share of the credit. The field crew varied somewhat over time, but a few faithful members showed up consistently throughout the entire project. Besides Cox, Smith, and Snavely, we wish to thank Roger Johnson, Marny Morgan, Kay Hindes, Frances Meskill, and Sylvia Reyna who contributed their talents and enthusiasm on a regular basis. In addition, when we sent out a call for help with the extensive excavations at the site of the funeral pyre, over 40 volunteers turned out to work over several weeks. They were not only from San Antonio but from as far away as Dallas and Houston, and we could not have done this work without them. The weather was generally awful-cold, windy, and rainy-and they stuck it out until the end, despite the fact that we never did find any indication that the Alamo heroes were burned in that location.

Final organization and composition of this manuscript could not have been accomplished without many hours of concentrated work by Kevin Gross, who did artifact descriptions and analyses for a number of the sites despite the fact that he did not participate in the fieldwork. This is due in great part to the detailed and accurate field records and drawings created by the excavation crew throughout the project.

Staff members at CAR have worked together to produce this report. The numerous drawings were drafted by Bruce Moses and Barbara Meissner. The artifact photographs were taken by Maureen Brown. Cindy Tennis, small-projects manager for CAR, assisted with preparation. 


\section{Part I: Project Background}

\section{Contents}

Chapter $1:$ Introduction

Chapter 2 : Project Design

Chapter 3 : Methodology

Chapter 4 : History of the Project Area 


\section{Chapter 1: Introduction}

\section{Introduction}

In September 1984, San Antonio Mayor Henry Cisneros announced to the public that a new hotel and shopping complex was to be constructed in the downtown area. The development was originally called Las Tiendas del Rio, then later renamed Rivercenter Mall. The complex is located just east of the San Antonio River, a few blocks south of the Alamo.

The Center for Archaeological Research (CAR) of The University of Texas at San Antonio was contracted to conduct archival research and on-site testing and mitigation prior to construction of the complex. The archaeological investigations were conducted under Texas Antiquities Committee permit number 433, with Jack D. Eaton serving as principal investigator. Anne Fox served as principal investigator for the analysis and reporting stages of the project.

\section{Setting}

The Rivercenter Mall project is located on a level plain, four city blocks from the east bank of the San Antonio River and one block south of Alamo Plaza (Figure 1-1). During the Spanish colonial period, the area was part of the irrigated agricultural fields for the Mission San Antoio de Valero (the Alamo). In the mid-nineteenth century, it became a residential neighborhood of small homes surrounded by trees and gardens. It then very gradually disintegrated into large parking lots interspersed with deteriorating commercial building. In this condition, it was in no way living up to its true potential and was, therefore, attractive to prospective commercial developers.

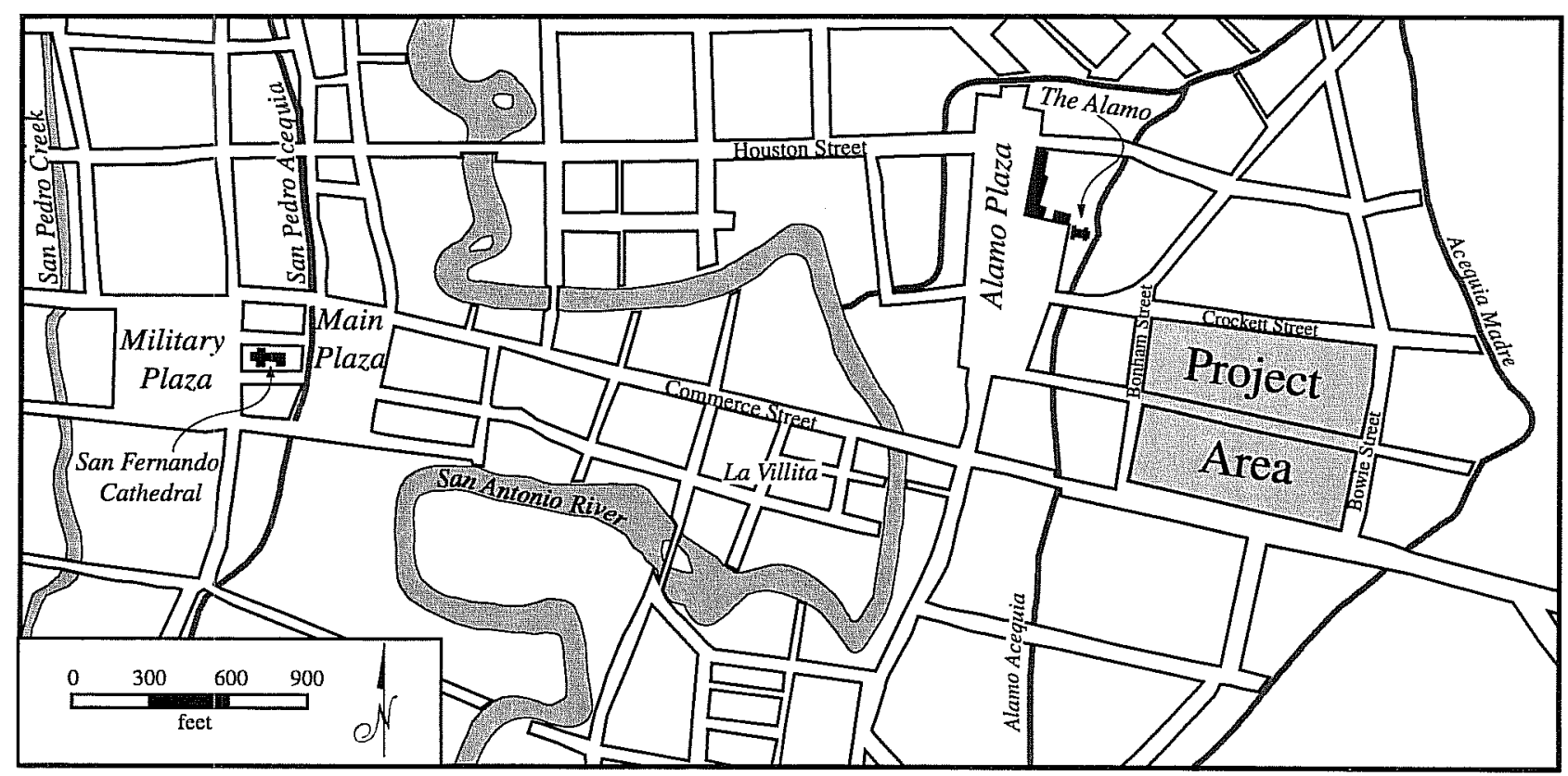

Figure 1-1. Project location. 


\section{The Rivercenter Mall Project}

Rivercenter Mall was to be constructed by private developers at a cost of $\$ 140$ million and would contain the city's largest hotel; $185,000 \mathrm{ft}^{2}$ of retail space; $300,000 \mathrm{ft}^{2}$ of office space; and 1,400 $\mathrm{ft}^{2}$ of parking garage. The city had acquired $\$ 15.7$ million in Urban Development Action Grants (UDAG) and would commit to extending the San Antonio River and the Riverwalk to the development, as well as widening Bowie, Crockett, and Houston streets to accomodate the expected increase in traffic (San Antonio ExpressNews [SAEN], 28 September 1984). This project would serve as a major factor in revitalizing the downtown sector and to stem the rush to the suburbs that had begun some two decades before.

Plans were presented to the city of San Antonio by Williams Realty Corporation, developer Edward J. DeBartolo, and Allied Stores to build the complex on the location of the parking lot owned by the downtown Joske's Department Store. The area involved included three designated city blocks (NCB152, 166, and 1010) and a portion of another (NCB 125) which was later excluded from the project. Included in the plans was an extension of the river channel beneath Commerce Street and into the new mall. The project area, as finally determined, was bounded on the north by Crockett Street, on the east by Bowie Street, on the south by Commerce Street, and on the west by Bonham Street (Figure 1-1).

In consultation with the State Historic Preservation Officer (SHPO), the city determined that implementation of the project would adversely affect the nearby Alamo Plaza Historic District, which is listed on the National Register of Historic Places. This required the comments of the Advisory Council on Historic Preservation. In consultation, representatives of the Advisory Council, the city, and the Texas SHPO reviewed plans for the project. They mutually agreed that an archaeological survey and mitigation would be done as stipulated in the proposal submitted to the city by the Center for Archaeological Research (CAR) of The University of Texas at San Antonio. The work was to be accomplished in orderly phases in a logical progression from research to testing to excavation, with the results to be published by CAR.

\section{Project Planning}

Phase I of the project consisted of a preliminary archival and literature search to determine the cultural resource potential for the development area. The resulting report (Markey 1981), dated November 10, 1981, was accepted by the city. Phase II consisted of an architectural review of the standing structures on the site (copy on file with the city of San Antonio), and was performed by a local architectural firm in contract with the city. Phase III, addressed by the CAR proposal, was designed to accomplish additional indepth research on individual lots to determine the areas of significant activity; machine and hand testing to determine the location and condition of resources; preparation of a data recovery plan with recommendations to the city for nomination of significant resources to the National Register; and finally, mitigation where deemed necessary. CAR was to monitor all building demolition and street and utilities relocation throughout the project. The results of Phase I research and Phase III testing and mitigation are included in this volume.

Plans were made to coordinate the archaeological field investigations with the project construction schedule, so as to clear areas needed for machine excavation before that work was due to begin. As anticipated, it became necessary to keep personnel available throughout the project for various details not involved with the actual excavations. Coordination with the contractors allowed selected crew members to monitor the demolition of buildings still standing on the site whenever needed, as this activity was ongoing throughout much of the project. An added complication was the fact that the use of the site as a parking lot continued throughout the Phase III testing operation. This required daily traffic control efforts and limitation of backhoe testing to one specific small area at a time, then immediate backfilling of all trenches before moving to another area.

Prior to 1982 , CAR had conducted several archaeological excavations in downtown San Antonio, but this was the largest in scope. Due to various delays-although the laboratory processing, artifact identification, and most of the analysis had been accomplished-the final report had not been completed when the city of San Antonio contracted 
with CAR to conduct an even larger project in advance of the construction of the Alamodome multi-use facility. The experience gained from the Rivercenter Mall project contributed substantially to the planning for the Alamodome project and helped immeasurably in anticipating what would be found during the archaeological excavations. Both projects have simultaneously arrived at the final stages of report production, allowing considerable cross-referencing between them. In the process, we feel both projects have benefited in scope and depth. 


\section{Chapter 2: Project Design}

\section{Urban Archaeology}

Dickens and Crimmins (1982:106) remark on the fact that up to the 1960s, American archaeologists had tended to neglect urban areas as a basis for research, concentrating instead on Colonial and early nineteenth-century sites. The first large-scale urban projects were initiated in Tucson, Arizona; Lowell, Massachusetts; and Patterson, New Jersey, in the late 1960s and early 1970s. These excavations sparked a growing interest in urban archaeology and the realization that the city can be studied as a "unified and significant body of cultural resources" (Dickens and Crimmins 1982:107). The additional realization that the city is "a complex and ever-evolving organism" (Dickens and Crimmins 1982:107) challenges archaeologists to determine how various neighborhoods relate to the city as a whole, and how their evolution reflects the growth of the entire city.

\section{Previous Archaeological Studies in the Project Area}

The Rivercenter Mall Project was the first large-scale urban project in San Antonio, and actually the first in the entire state. Previous local projects involved investigation of a lotby-lot basis, concerned with a single structure and its history (Fox 1977; Ivey 1978a, 1978b, 1982). The only previous project approaching this one in scope was the Arciniega Site Project (Katz 1978) which involved part of 1.5 blocks in downtown San Antonio. The scale of the Arciniega Site Project was modest, involving only a few families. The value of the project was that we were learning how to handle a multi-structural, multi-family situation. The Rivercenter Mall Project has benefited from this experience by teaching us how to find and trace structural foundations on an open lot with no surface clues. We also learned how to anticipate the location of outbuildings containing privies, how to safely and expeditiously excavate privies and other subterranean disturbances, and how to locate and recognize acequia laterals.

\section{Research Design for the Rivercenter Project}

\section{Test Site Selection}

Due to the magnitude of the project area (75 lots with a probability of at least 153 structures and outbuildings), it would not be practical or cost effective to test all components of the site. Therefore, adhering to the guidelines of the Handbook of the Advisory Council on Historic Preservation (1980), CAR proposed that testing of carefully selected units would give an adequate representative sample (Figure 2-1). These units were selected, based on archival research, with a view toward consideration of a diversity of data retrieval, i.e., date of construction, type of construction, type of occupation, historic value, and ethnicity. Yet

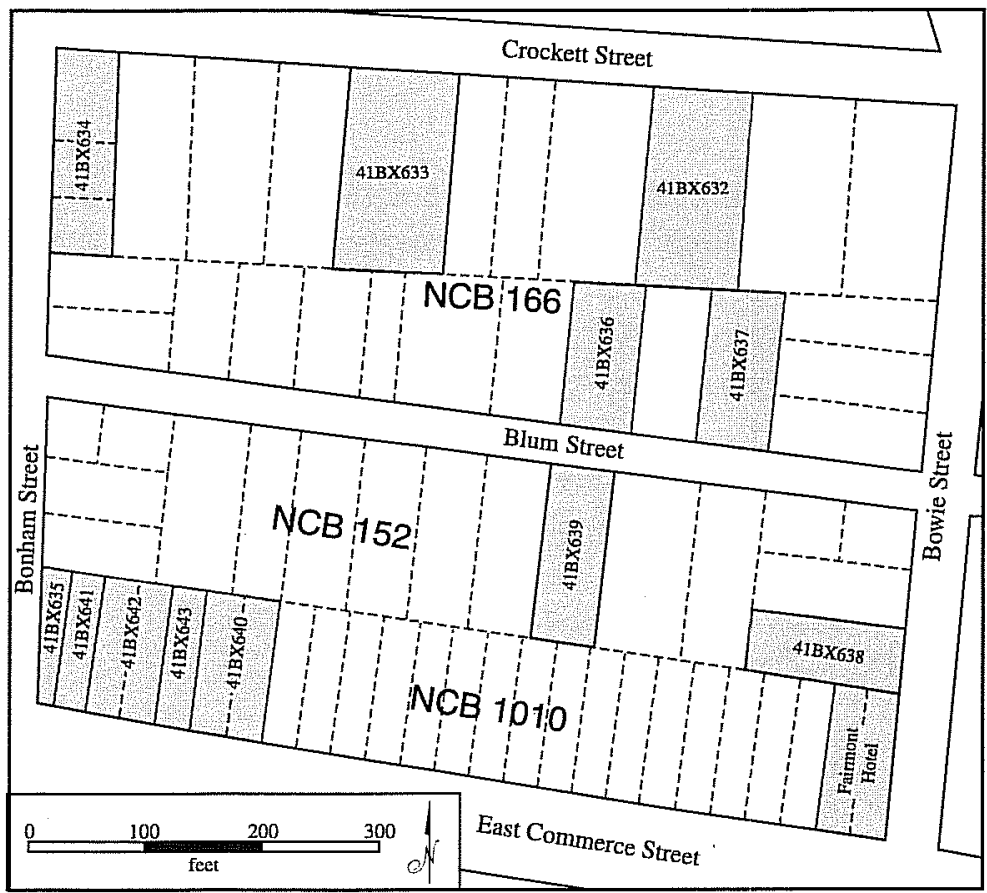

Figure 2-1. Map of project area showing lots investigated. 
the chosen areas maintain enough commonality to present a true picture of the essential character of the area as it changed through time.

\section{Research Questions to Be Addressed}

Numerous questions were formulated prior to the archival research and fieldwork.

1. Are discernible differences in social status, ethnic background, and economic status reflected in the archaeological remains?

2. What was the structural evolution in this neighborhood through time?

3. What differences exist in the artifacts between residential and commercial sites?

4. What historical or archival sources link the structures to their owners?

5. Are there records associated with the structures that would enhance their historical significance?

6. What support features (wells, cisterns, privies, etc.) are present, and how do they reflect cultural patterns?

7. Can structural placement within the lots predict locations for future excavations?

8. What diagnostic artifacts are present and what time periods are represented?

9. What cultural activities can be inferred from the results of this project?

10. What information can be retrieved from the acequia lateral within the area?

11. What conditions will be present under a parking lot surface?
12. What types of foundations will we find under "adobe" houses and how were they constructed?

13. Did nineteenth-century San Antonio houses usually have basements?

14. Can a house foundation tell us anything about the economic and social standing of the family for whom it was built?

\section{Priorities}

Since the questions of the evolution of the inner city and ethnic differences might best be answered by this study due to the number and variety of available sites concerned, these topics were given high priorities. Yet again, because of the scope of the project, the questions of lot usage patterns could yield information toward practical further investigations. Construction techniques could be compared with the results of work at other, similar sites within the city.

\section{Data Required}

Evolution of the inner city and of construction techniques may best be determined by the remaining physical evidence, with careful attention directed toward any change through time. The analysis of the artifact assemblage should be directed toward answering the questions of lot usage, use differences, and ethnicity. 


\section{Chapter 3: Methodology}

\section{Introduction}

Due to the high visibility of the project, there would be no problem of public awareness of the work to be done. There had already been a great deal of press interest indicated, with more promised for the future. There were also a number of requests from persons wishing to volunteer help, and a notification list was prepared. Also, in order to allow local amateur archaeological groups and others the greatest opportunity to participate, some excavations were planned for weekends. Public briefings were also available on the site on a continuing basis.

\section{Archival Research}

All available Sanborn Insurance Maps, plat maps from Bexar County deeds, and bird's eye maps covering the project area were studied before going into the field. Information was extracted from City Directories and family histories as well as from files at the San Antonio Public Library and the DRT Library. These studies resulted in an overall history of the project area (Chapter 4), and the detailed history of each site used in the site descriptions in Part II.

An oral history program was initiated in connection with the project. Interviews were conducted with members of the families who once lived there and individuals who worked on, visited, or were familiar with the site during their lifetime. Tapes and transcripts of the interviews are on file at CAR.

\section{Field Methods}

Initial testing was to be accomplished by machineassisted excavation to ascertain the extent and condition of the structures present and the location of outbuildings and additional features. The documentation of the results of these initial tests was intended to form the basis for later analysis of the construction techniques and materials used in San Antonio during the second half of the nineteenth century. Once these tests were documented, a reappraisal was made, and the most promising areas of each lot were targeted for further full or partial excavation as dictated by budget and time limitations.

As sometimes happens, these plans had to be altered somewhat in the southern part of the project area (NCB 1010) to coordinate with the schedule of the contractors. In that area, it was necessary to conduct testing and mitigation together, doing mechanical scraping, hand-excavating, and extensive testing over the entire lot within the same time period.

\section{Phase III Testing NCBs 166 and 152}

Since the entire area was paved for parking, it was possible to lay out the approximate location of most structures with spray paint on the asphalt surface, using 100 -meter tapes and measuring from curb and fence lines. We then dug backhoe trenches north-south and east-west across the structures to reveal wall footings and construction details. Trenches were indicated numerically and alphabetically. Careful cleaning of foundations was followed by detailed field drawings of what was found, with particular care to note construction methods and materials. Examination of bumps and hollows in the asphalt surface in several cases revealed the approximate location of wells, privy pits, and foundations which were then considered for mitigative excavations.

\section{Phase IV Mitigation NCBs 166 and 152}

Phase IV of the project consisted of excavation of selected features such as wells, privies, and trash pits which had been revealed during Phase III testing. Four privies and one well were excavated during the mitigation phase. Descriptions and analyses of these 
features are included in this report. Excavations were carried out in stratigraphic levels wherever possible, excavating one half of the deposit and leaving the other half in place to record the stratigraphy. When features were too small to allow this treatment, the entire content was excavated and careful notes were kept of stratigraphic changes.

Since the locations of test trenches were observable on the surface of the unpaved parking lot, we could easily return to the desired locality for mitigation. Excavation of deep privy pits and the well required advance planning to insure the safety of the crew and the recovery of sufficient information from the feature. The fact that the area had been an open parking lot for a number of years meant that there were no barriers or restrictions on the direction or extent of our excavations. In each case where the excavation would be deeper than the OSHA limit for open trenching, we planned in advance to approach the feature from one side with a wide backhoe trench, removing the wall of the feature and excavating half of the enclosed deposit, leaving a profile of the remaining content for recording. All removed deposits were screened through $1 / 4$-inch hardware cloth and bagged according to depth.

\section{Testing and Mitigation NCB 1010}

When the project began, this entire area was the site of Joske's Tire Store, a one-story building which stood on a concrete slab. The building was demolished in December 1984. Archaeologists from the testing crew monitored the slab removal and recorded the remains of commercial buildings which stood in this area before the Tire Store was built. It was determined that basements under the buildings on Lots 1 through 5 had destroyed any traces of earlier occupation. The disturbance caused by the basement construction, building demolition, and construction and demolition of the Tire Store had completely churned up the southern half of Lots 1 to 5 .
There was a relatively undisturbed strip along the north block line (Figure 3-1). Since we anticipated that privies and trash deposits would be located in this area, testing was concentrated there and in relatively undisturbed sections of Lots 6 and 7. The parking lot paving and underlying gravel base were removed by backhoe in an area approximately $15 \mathrm{ft}$. wide across the back sections of Lots $1-7$. The newly exposed surface was then shovel-scraped to search for evidence of subsurface disturbances. The cleared area was marked off with the original lot lines, and separate artifact collections were made from the surface of each lot. From this point, all lots were treated as individual sites.

In the same manner, the remainder of Lots 6 and 7 was cleaned off to allow us to search for possible traces of the funeral pyre of the Alamo heroes. The latter was rumored to be located in that general vicinity (see Chapter 15).

\section{Artifact Analysis and Curation}

All recovered artifacts were washed, air dried, and cataloged in the CAR laboratory. They were then identified, sorted by type, and studied on a site-bysite basis. Field records consisting of daily logs, level forms, drawings and photographs are all curated at the CAR laboratory.

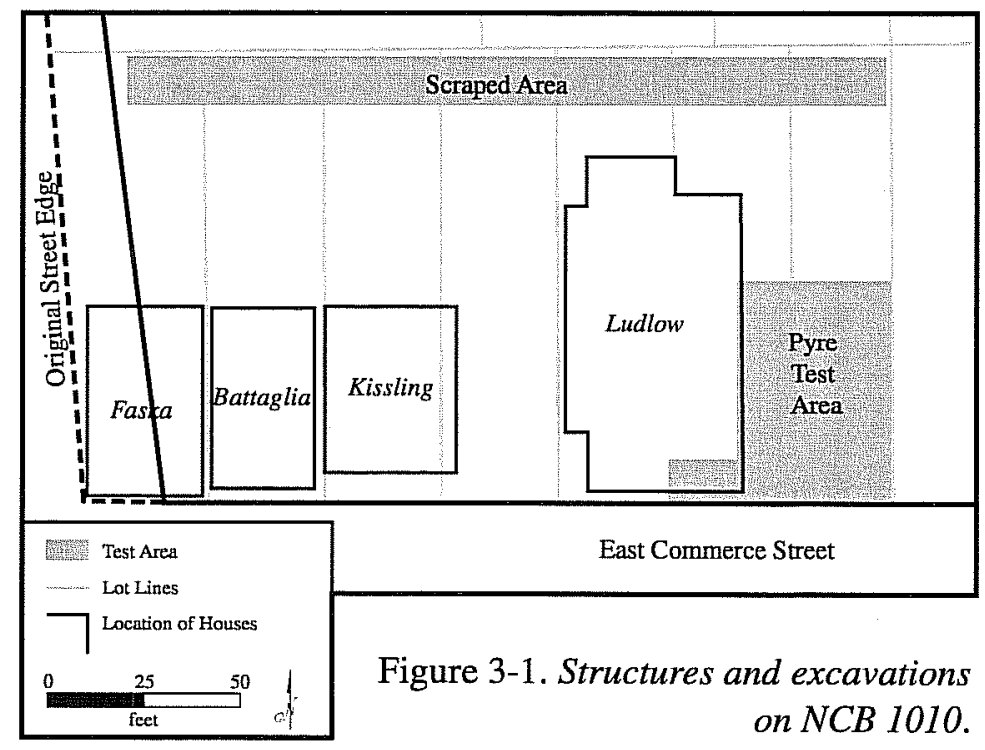




\section{Chapter 4: History of the Project Area}

\section{Early History}

In April 1709, Fray Isidro Felix de Espinosa and Fray Antonio de San Buenaventura Olivares, accompanying the entrada of Captain Pedro de Aquirre, departed Mission San Juan Bautista on the Rio Grande with the intent of establishing contact with the Tejas Indians of East Texas. On April 8, they arrived at the refreshing sight of a lush growth of greenery along a crystal-clear stream. Fray Espinosa noted in his diary that the lands along the river were capable of supporting "not only a village but a city, which could easily be founded here because of the good ground and the many conveniences, and because of the shallowness of said river" (de Espinosa 1709:5). They named the little stream San Antonio de Padua, for they had reached it upon the feast day of St. Anthony. Seven years later Fray Espinosa, while returning to the East Texas missions with the expedition of Captain Domingo Ramon, again praised the attributes of the area. "This river is very desirable and favorable for its pleasantness, location, abundance of water, and multitude of fish. It is surrounded by very tall nopals, poplars, elms, grapevines, black mulberry trees, laurels, strawberry vines and genuine fan-palms . . . Its luxuriance is enticing for the founding of missions and villages, for both its plains and its water encourage settlement" (de Espinosa 1716:9).

Espinosa's vision finally became a reality in 1718 , when Governor Martín de Alarcón founded the mission of San Antonio de Valero, later to be called the Alamo, near the San Antonio River. The mission was shortly thereafter relocated to the east bank of the river (Habig 1968:44) at the point of a large bend near an excellent ford. Mission San Antonio de Valero's acequia, or irrigation ditch, was begun in 1719. It began at a shallow ford below the springs that formed the headwaters of the river and progressed southward, following the contours of the land, to the east of the mission and provided water for the missions land to the south. This Acequia Madre, or "Mother Ditch," returned to the river just south of downtown San Antonio. A secondary branch was constructed from the Madre at a point several blocks north and progressed toward the west to pass through the mission compound. All of the lands between the acequia and the river were designated as the mission fields.

In 1720 Fray Antonio Margil de Jesús founded Mission San José y San Miguel de Aguayo south of Valero on the same side of the river. In 1731 three missions from east Texas were withdrawn to San Antonio and settled downstream from the town. For the next 50 years the missions grew in size and influence, then gradually declined.

\section{Secularization}

By 1778 Fray Juan Augustin Morfi, author of the first history of Texas, noted that since 1762 the number of Indians "has greatly reduced, and today the mission has scarcely enough of them to cultivate the fields" (Habig 1968:63). In 1788 Fray José Rafael de la Santisima Trinidad Oliva stated that " the decreasing number of the Indians increases the number of salaried workers, and the continuous maintenance of it all brings many cares to the Missionaries" (Leutenegger and Habig 1977:28). Noting the lack of further productivity to be achieved by the missionization program, in 1779 government officials issued orders to Governor Don Domingo Cabello to take action to close the missions and divide the lands among the Indians. However, due to resistance from the clergy and other factions, this was not carried out for some 13 years. Finally, on January 9, 1793, Governor Manuel Munoz ordered the suppression and secularization of the missions (Habig 1968:66).

The Valero lands were surveyed and subdivided and, on April 12, distributed to each of the remaining 14 heads of families and unmarried adults, granting each a tract of land large enough to plant one and threefifth bushels of seed. Similar plots were awarded to Pedro Huizar and Vincente Amador, the surveyor and his assistant (Habig 1968: 66-67). In addition, the Adaesaños, landless Spanish citizens relocated from 
East Texas and Louisiana after those lands were ceded to the French, were also given the opportunity to draw for a portion of the mission lands (Webb 1952:I:82).

The tracts of land within the project area were located between the two branches of the Alamo acequia to the immediate south and east of the mission proper. A broad park was established spanning across this area; this became a tree-lined boulevard known as the Alameda, a shaded walk. The area originally consisted of three tracts, or suertes, surveyed by Huizar; each tract varied in area due to the meanders of the river and acequia, and the land assigned was determined by drawn lots, the acreage received depending upon each persons suerte or "luck." The first tract, or northernmost suerte, lay within the branches of the acequia at the present-day intersection of Bonham and Bowie streets, and extended to just below today's Crockett Street. It was first granted to Juan Bautista de la Zerda, one of the displaced settlers for the Presidio of Los Adaes (Mission Records [MR], Bexar County Archives, Bexar County Courthouse, San Antonio, Texas, 1793, Book 2:17). The property later passed to his heirs, Antonio Milo and Josepha de la Zerda, and in turn to their heir, Cassaino Zerda. The second tract, now the lower half of New City Block (NCB) 166 and all of NCB 152, was granted to another Adaesaño, Manuel Losoya (Spanish Archives [SA], Bexar County Archives, Bexar County Courthouse, San Antonio, Texas, 1703, 3:302). It was then conveyed by Losoya to Leonicio Lopez (SA 3:143), who in turn sold it in 1806 to Antonio Martinez (Land Grants and Sales [LGS], Bexar County Archives, Bexar County Courthouse, San Antonio, Texas; 1806, No. 353). The final suerte, now NCB 1010, was granted to yet another Adaesaño, José Luis Hernandez (SA 3:229). His will of April 17, 1809, passed his estate jointly to his wife, Maria Barbara Sanchez, and his only son, José Antonio Hernandez (Wills and Estates [WE], Bexar County Archives, Bexar County Courthouse, San Antonio, Texas, No. 62). The property was later acquired by Pedro (Pierre) Longivilla (Chabot 1937:162).

There is no evidence of any substantial development within the area, outside of agricultural endeavors, during the early growth of San Antonio. In fact, the area east of the river was largely ignored after the secularization of the mission. The acequia system continued to serve the area serving as both drinking water and irrigation until the late 1890s, and even after that provided a channel for storm drainage until 1904. The state of Alamo Plaza in 1848 is vividly pictured in the description of the arrival of Dr. Ferdinand Herff and his wife to their new home. "Their entrance into Alamo Plaza was depressing after the delightful journey. The historic square lay muddy, covered with weeds, unkempt and neglected, its shrine standing gaunt and desolate" (Herff 1973:27). A further picture of the city in 1850 shows no substantial improvement, "Superficially prosperous, the city was undergoing an aftermath of depression related to the devastating cholera epidemic of 1849 . . Occasional attacks by hostile Indians and grossly inferior methods of sanitation further decimated the ranks of potential patients" (Herff 1973:34).

\section{The Republic and Statehood Periods}

The emergence of Texas as a Republic did not immediately correct its internal problems or its restricted growth. The challenges to its autonomy and territorial claims were to erupt into open warfare with Mexico throughout the decade of the existence of the financially troubled Republic. In August 1838, Vicente Cordova, a long-time opponent of the Anglo-American settlers, led a rebellion against the fledgling Republic, prompting President Thomas J. Rusk to call out the militia to suppress the rebellion (Webb 1952:II:412). In March 1842, Rafael Vasquez, commander of the Mexican Centralists, occupied San Antonio with 500 700 men (Webb 1952:II:834). In September of the same year, General Adrian Woll again captured the city and incarcerated most of its leading citizens in a Mexican prison (Webb 1952:II:928). The annexation of the Republic by the United States in February 1846 solved some of its financial problems, but not its border conflicts, as Mexico continued to contest the disputed territory. This resulted in the movement of American troops under General Zachary Taylor across the Nueces River, provoking war with Mexico (Webb 1952:II:276).

Despite these problems, the period between annexation and secession marked the period of the most rapid growth in the state's history. Its population increased 
more than fourfold and its assessed property by twice that figure. Ninety percent of this immigration was composed of native-born Americans from the old South (Fehrenbach 1968:279). San Antonio also experienced this growth surge, but with an entirely different character. The population of the city in 1830 numbered only 1,612 , but by 1840 had increased to approximately 2,000. In 1850 the first United States census indicated a population of 3,488 , but by 1860 the population had surged to 8,235 , an increase of 136 percent. San Antonio's growth was primarily composed of immigrants from Europe; by 1850 , Europeans, mostly German, outnumbered both Mexicans and Anglos.

This unprecedented growth created a phenomenon new to this raw frontier: land speculation. Poor in cash, but rich in land, as guaranteed by the unique agreement of its right upon annexation to retain all public lands, the state was generous with its primary asset. Land grants and headrights as a reward for valor, longevity, residency, or immigration were freely distributed. Vast tracts of land-unseen and unsurveyed - changed ownership throughout the state, but the center of this exchange was the edge of the frontier, Bexar County. Samuel A. Maverick wrote his wife, Mary: "the land business here is carried on by the most artful fellows on earth and they stop at nothing; so I can not expect to come off even with them" (Letter from Samuel Maverick to his wife, Mary; Barker History Center, Maverick Collection, The University of Texas at Austin; February 26, 1838, Book A:10). This was an extremely modest appraisal since he was to become one of the most successful of this new class of entrepreneurs. This fever of speculation also prompted visions of expansion within the undeveloped areas of San Antonio. With the increased population and expanded economy generated by the cash flow resulting from military spending and increased commerce with western Texas and Mexico, far-sighted individuals began to purchase the mission tracts from the heirs of the grantees, usually at extremely low values, and to subdivide them into individual town lots. Three such visionaries were the sponsors of the divisions of the project area.

The upper suerte of Zerda (from Crockett Street to the intersection of Bonham and Bowie streets) was purchased, in January 1839 , by Asa Mitchell for $\$ 200$.
Mitchell made no improvements to the property and conveyed it intact 10 years later to John James Giddings (Bexar County Deed Records [BCDR], Office of the County Clerk, Bexar County Courthouse, San Antonio, Texas; A2:159, H1:109). Giddings (1821-1861) was one of six brothers who immigrated to Texas during the period of 1836-1846; all were destined to make their mark on the new state. ${ }^{1}$

The Losoya tract (NCB 166 and 152) below Crockett Street passed to Maria de los Santos Gortari in 1841 who later died intestate. In 1851 the Supreme Court of Texas awarded the property to her daughter Isabella Gortari, who the following year conveyed it to her only son, Ricardo Hernandez (BCDR B2:251). In April 1852 , Hernandez sold the property intact to Charles N. Riotte (BCDR K1:608). Riotte (1814 ca. 1874), the son of a Prussian noble family, was among the founders of both the Casino Association and the GermanEnglish School. He was also the founder of the FreeSoil party, and when Texas seceded in 1861, had the dubious distinction of being the first person asked to leave. He served as the minister to Costa Rica under President Lincoln, and minister to Nicaragua under President Grant (BCDR K1:608; Texas State Archives [TSA], Biography File, Austin, Texas).

The third tract (NCB 1010) facing Commerce Street passed to the heir of Pedro Longivilla, Francisco, who sold the property to Edward Dwyer for the sum of $\$ 300$ in 1845 (BCDR C2:188). Dwyer (1815-1854) was an immigrant from Ireland who married into one of the original Spanish families of San Antonio. A prominent businessman, he owned vast amounts of property throughout the state and served as mayor of San Antonio from 1844 to 1846 (Buck 1980:285; Chabot 1937:152).

\footnotetext{
${ }^{1}$ The eldest brother, Giles Albert Giddings, was mortally wounded while serving under General Sam Houston (Chabot 1937:314). Jabez Deming Giddings and DeWitt Clinton Giddings, law partners in Brenham, Texas, both had long and distinguished careers (Webb 1952:I:686). George Herry Giddings founded the San AntonioSan Diego Mail, the first intercontinental stage line. Frances Marion Giddings, a doctor, died at the hands of a desperado in El Paso while transferring the mail to Mexico. John James Giddings surveyed the lands for the German colony in Texas prior to joining his brother as a driver for the stage line (Chabot 1937:314).
} 
Each of these investors subdivided his parcel into individual town lots for prospective resale to individuals. Despite what were probably high hopes for the expansion of the area-no doubt well founded by the establishment of the U. S. Army Quartermaster Corps at the old Mission Valero in 1849-the project area was slow to develop residentially. Increased growth in commerce and transportation facilities occurred, but little interest in a general movement of homes into the area did not. Only corner lots suitable to commercial use and residential lots convenient for those employed within the immediate area were sold.

A major turning point in the development of Alamo Plaza was the construction of the Menger Hotel in 1857 (Everett 1975:116). This establishment became the center of activity for the growing influx of visitors and businessmen into this part of town. Its brewery, catering to the increasing German immigration into San Antonio, became a social center drawing others to the neglected eastern bank of the river. The area soon acquired a predominantly European nature. The establishment of the German-English school in 1858 and the founding of St. Joseph's Church in 1868 added a German flavor.

\section{Civil War}

This encouraging expansion, no doubt fostered at least in part by Riotte, was to be abruptly curtailed by events totally unforeseen in the formative years of the development. The growth of the area was badly hampered by three unrelated events. The first factor was the untimely death of Edward Dwyer at age 53. His estate was inherited by his wife, Mariana, and she distributed it in equal shares to their children (Probate Court Records [PCR], District Clerk's Office, Bexar County Courthouse, San Antonio, Texas). Their eldest child, Anita, received the land within the study area. Anita was the wife of John Withers, who was to serve as adjutant general of the Confederacy under General Robert E. Lee (Lewis Publishing Company 1907:319). The second event to impact the area was the killing by Indians of John J. Giddings while he was accompanying his brother's stagecoach returning from the west to El Paso in 1861. The Indians, under the leadership of Chief Cochise, attacked the coach on the same day that Fort Sumner was bombarded by
Southern forces. Giddings's body was never recovered, "all that was found was a boot and one glove" (Chabot 1937:315). The final, and most dramatic event, was the secession of Texas from the Union in March 1861. These events combined to delay the development of the southern section of the project area until after the Civil War.

The Civil War was to have a pronounced effect on both the economy and the growth of San Antonio. The first effect of the war was the total blockade of the Gulf coast proclaimed by President Lincoln in April 1861 , forcing an immediate economic revolution (Delaney 1955:474). Items that had been traditionally imported from the Northern industrial states were suddenly curtailed; such basic items as salt, guns, clothing, and medicines had to be produced at home. Additionally, the drain of able-bodied men to arm the Confederacy threw the burden of maintaining the home front onto the women, older men, children, and slaves (Fehrenbach 1968:356-7). These conditions brought the growth of the frontier almost to a halt.

A contrasting effect of the blockade was created by the new source of wealth that it would bring to some. The blockade was to virtually eliminate the flow of cotton required by European and Northern textile mills. In England alone some four million people were dependant upon southern cotton for their livelihood (Delaney 1955:475). This demand, coupled with the escalating value due to supply and demand, created a vast trade in cotton into the free ports of Mexico, protected by the delicate international situation with the adjacent neutral nation (Sibley 1973:40). Early in 1863 from 180 to 200 ships of all nations (including the Northern states) lay at anchor off the mouth of the Rio Grande waiting to discharge cargo and receive cotton (Delaney 1955:483). This vast network of trade would all pass through San Antonio. "By June 1864, traffic through the town became so dense that the city council was forced to levy a tax on each bale carried through its streets to cover the cost of road and bridge repairs and to pay for the removal of hundreds of animal carcasses abandoned by the wagon trains" (Kerby 1972:178-9).

By the onset of the Civil War, both Giddings and Riotte had disposed of the bulk of their lots, and residences 
had been established along much of Crockett and Blum streets. None of the Devine lots on Commerce Street had been sold and the Alameda remained a park as it had been since the days of the Spanish government. No further development was to occur until after the conclusion of the conflict.

\section{The Late Nineteenth Century}

The years following the war were bitter times for Texas, indeed for the entire South. The economy was a shambles and its citizens broken and demoralized. "The economy and future of Texas lay in ruins. Fully one-fourth of the productive white male population was dead, disabled, or dispersed. Almost every form of real wealth, except the land itself, was dissipated or destroyed" (Fehrenbach 1968:394). The problems of recovery were further compounded by the excesses of the Carpetbagger regime imposed upon Texas by the Northern military control. The "ironclad" loyalty act disenfranchised anyone who had ever been "a mayor, school trustee, clerk, public weigher, or even a cemetery sexton" from public office (Fehrenbach 1968:410). This often resulted in the miliary appointment of grossly incompetent and corrupt officials.

San Antonio, as a whole, was to fare much better during this trying period than the majority of the state due to several unique circumstances. First, because of the neutrality or outright Union support of many of its leading citizens, several well-qualified and experienced candidates for public office were available for the military to draw on. Wilhelm Carl August Thielepape, an educated and qualified Unionist, was appointed mayor in 1867 by General J. J. Reynolds, the federal authority in Austin (Corner 1890:67). He was to serve capably until 1872 . A second factor was the return to San Antonio of the U.S. Army. Although now an army of occupation, it was nonetheless a source of "greenback" money for the local economy as the flow of supplies and men passed through the area to re-man the frontier forts, serving in some measure to ease the Indian problems (Fehrenbach 1978:103). The third effect, and probably the most important to the city, was the growth of a new industry: the cattle drives that arose to supply the beef-hungry North. San Antonio, as the only major city on the vast frontier, was the primary benefactor, as it had been from the cotton trade. Rough and tumble San Antonio became the capital city of the short-lived cattle empire (Fehrenbach 1978:107).

Yet these were still hard times beset by many problems. Funds for city improvements were nonexistent. The gas works, established in 1859, lay idle due to lack of money to operate it. The streets were dark and rough, and in bad weather almost impassable, with vehicles remaining mired for days. Trash and garbage filled the yards and streets (Morgan 1961:49). A major problem was the antiquated water system; water was still obtained from shallow wells, cisterns, and the acequia system, just as it had from the days of the Spanish padres. Many of these water sources were contaminated by the casual introduction of filth and seepage from the ever-present outhouses (Morgan 1961:50). "The habit of depositing cats, and other luxuries that the citizens have no further use for, in the stream [San Antonio River] coupled with the inability of the slow current to transport them outside the city limits until they have become infirm with age, has done much to make cistern water popular" (Sweet and Knox 1905:309). As a result of these conditions, cholera became epidemic in San Antonio in 1866. While not as severe or extensive as the one endured in 1849,198 deaths were recorded in the last 12 days of September and 112 in December (Nixon 1936:136).

The need for improved water and sanitation systems had long been recognized and promoted by physicians and the Public Health Board. In fact, it was the public issue of the attempt by Mayor Thielepape to purchase the headwaters of the San Antonio River from George Brackenridge that prompted his ouster from office (Sibley 1973:129). In 1873 George W. Maverick proposed an active program for a public water works system, but the proposition failed due to the continuing monetary problems and the national financial panic in the United States (Morgan 1961:53). In 1875 a second attempt to improve public sanitation was initiated by $\mathrm{H}$. B. Adams, only to meet equal opposition (McLean 1924:5). The availability of proper sanitation and healthy water was to succumb to what most considered a more important and tangible economic reality. 
In 1875 San Antonio was the only major city in the nation that was not serviced by a major port or railway. All goods, still primarily supplied from the North, had to be transported by cart or wagon over admittedly inferior roads to supply a city that had now fallen to Galveston as the most populous in the state. It was openly apparent that San Antonio could no longer aspire to grow, much less maintain its distinction as a major western terminus, without the advent of rail transportation. It had already seen its title of cattle capital usurped by the introduction of iron rails into the state. The railroad was the link to both today and tomorrow that was imperative for access to the industries of the east and the growing markets of the west. The arrival of the Galveston, Harrisburg and San Antonio Railroad (GH\&SARR), on February 19, 1877 , was greeted with pomp and splendor unprecedented in all of San Antonio's often flamboyant past. Heralded as "the greatest event connected with the history of our city," thousands cheered its entry into the new terminal only a few blocks northeast of the Alamo (SAEN, 20 February 1877).

This new thrust of economy into the city was to generate both the revival and the demise of the subject area. It would project the oft-neglected suburb into commercial growth and finally end its character as a family residential quarter. Commerce and Austin streets became the major access route into the railroad terminal, causing business to push eastward across the river. What had been single-family residences and family businesses became rentals and commercial lots, with only a few notable exceptions. On some of the lots, prominent residents, such as the Callaghan and Tengg families, had settled in the subdivision and were to remain. The area was a composite of nationalities, bridging between Irish Flats to the north, Germans to the south, and the mixed Polish and German settlement to the east on Commerce Street.

The entry of rail transportation into San Antonio was without question one of the major factors in transforming the raw frontier town into an emerging city, thrusting it into the new "Golden Age" of America. Now San Antonio was forced to face the image it was projecting to the nation. "When the railroad entered San Antonio, there was no sewer system or drainage except the river, no sidewalks and a great deal of mud, even during dry weather, because of the overflow of the irrigation ditches which still were the principal source of water supply" (Morgan 1961:55). Ready to meet this challenge was one of the city's more forceful mayors, James Henry French. Elected in 1875 , he was to hold the office continuously for the next 10 years. Under his administration, action was initiated to improve the streets, develop public transportation, establish fire departments, and re-name and number the tangle of streets, allowing the first implementation of mail delivery (SAEN, 28 February 1939).

The necessity of supporting the new growth of the city again brought the question of the water system into the public consciousness. In April 1877, the city gave a contract to Jean Batiste Lacoste and Associates to supply water to the city from the head of the river. The work was completed and accepted by the city on July 5, 1878. Yet the public was reluctant to change old habits, and acceptance of the system was disappointing. In 1883 the company was sold to George W. Brackenridge (McLean 1924:6). "The works took a new lease of life under Mr. Brackenridge. With a serene faith in the future of the city he has yearly put and advised his company to put thousands upon thousands of dollars underground until today the city has a vast network of iron pipes" (Corner 1890:5556). The anticipated growth by the introduction of the railroad soon became a reality. The population increased from 17,314 in 1876 , to 20,550 by 1880 , and was destined to rise to 37,673 by 1890 , an increase of 117 percent (Fehrenbach 1978:117; U.S. Census $1880,1890)$. This surge was comparable to the rapid growth experienced during the pre-Civil War period. However, the newcomers this time were no longer predominately European, but instead consisted primarily of families from the South (Fehrenbach 1978:121). A major manifestation of this influence was the growth of the King William area, six blocks south of the study area. With the new expansion the wealthier, older families constructed lavish homes along the eastern bank of the river. Their architecture, however, was not German but rather "early Victorian" with a few modifications (Burkholder 1973:10-11).

The arrival of rail transportation also had a major impact upon the architectural style of the entire city 
of San Antonio. Prior to the 1870 s, the primary construction materials were caliche and limestone blocks, but with the introduction of inexpensive transportation cost for material too heavy or bulky for overland shipment, brick brought in from the east and later Laredo became a popular and preferred material. This was further promoted by the establishment of local brick companies, capitalizing on the increased demand. In addition to local production, no less than 190 car-loads of brick were transported to San Antonio by rail in 1884 alone (Land and Thompson 1885:38). Another innovation during this period was the introduction of a new building material from a local source. William Lloyd, an Englishman on a hunting trip north of the city, discovered a distinctive calcitic rock. An analysis by George H. Kalteyer, one of the town's leading druggists, revealed that it was an excellent cement source, resulted in the establishment of the Alamo Cement company in the quarry that is now the Sunken Gardens of Brackenridge Park (Odom and Young 1985:50).

The railroad opened yet another major market for San Antonio: the wool trade. With the arrival of transportation facilities, the wool route shifted from New Braunfels to San Antonio. The extension of the International and Great Northern Railway (I\&GNRR) to west Texas in 1888 opened vast new markets, and wool became a major commodity of trade, with up to $10,000,000$ pounds of wool received in a single year (Morrison 1977[1891]:69). The receipts of 1884 reflect $7,000,000$ pounds received, and in 1890 shipments of $6,000,000$ pounds valued at a prevailing market rate of $\$ 1,200,000$ (Land and Thompson 1885:32).

In 1885 the city elected a new mayor, Bryan Callaghan, the son of an Irish immigrant who had married into one of the city's original Spanish families; in cooperation with his political machine, "King" Callaghan controlled San Antonio for the next 30 years. While some claimed that he ran the city for "gamblers, riffraff, and crooks," others "considered him more of an asset than the Alamo" (Morgan 1961:67). Although San Antonio now had a modern water system, it still had major sanitation problems. Although the first bond issue to provide for a modern sewer plant was introduced during Callaghan's first term, it was not until 1897 that the issue passed and a sewage plant was in operation. It was not until after 1900 that local inhabitants began building indoor bathrooms in new homes (Morgan 1961:92).

Within the study area, water was first available to the homes in approximately 1879 , but there was little rush to pipe it into the home directly; often the water connection was merely an outlet pipe in the front yard. Wells and privies were common in the area until after the turn of the century. Most of the homes were rentals and several had been converted for small businesses. A few of the older families still owned and occupied their original homes, but the area in general had begun to grow a bit shabby and rundown. Commerce Street was fully commercial at this point, but the middle lots of the block were still vacant and unused. It was not until after the turn of the century-when the railway depot was relocated to the east of the area-that it began to attract more substantial structures and businesses.

The city, however, was beginning to show signs of modernization. Starting in 1878 , the city was linked by four systems of mule-drawn public trolleys, to be replaced in 1890 by electric-powered coaches (Corner 1890:6; Fehrenbach 1978:290). George Brackenridge installed the first telephone line in his bank in 1881, and the following year the system connected 200 subscribers (Odom and Young 1985:54). By 1887 an efficient electric power plant was in operation (Fehrenbach 1978:129). Banks and breweries flourished, and in 1888, the new Joske's store was established at the corner of Alamo and Commerce. This mercantile establishment would grow to become a San Antonio landmark, and would dominate the business trade along Commerce Street for almost a century (Odom and Young 1985:48). By 1900 the population had reached 53,321 , a substantial city at the turn of the century (U.S. Census 1900).

Yet San Antonio had not entirely abandoned its colorful past; it was known as the "flashy, sin-dazzling metropolis of wild and wooly Texas ... pleasure capital of the Southwest" (Morgan 1961:2). Evangelist Dixie Williams railed "San Antonio is the wickedest city in the Union, not excepting Washington City, which is the wickedest out of Hell" (Morgan 1961:3). As the 
new century dawned, San Antonio emerged as a great city, largest and grandest in the state. Cattle millionaires and the expanding military complex at Fort Sam Houston gave the area economic stability (Fehrenbach 1978:149). San Antonio continued to grow and the advent of the automobile encouraged development of fashionable subdivisions to the north. Its west side remained predominantly Hispanic and the southside expanded with the homes of tradesmen and blue-collar workers, while the small community of blacks on the east side began to move toward the edge of town and develop their cultural center a few blocks to the east. Time was not, however, kind to the subject area; even the rental homes had given way to small hotels and rooming houses. As the area declined, the lots were one by one sold to the Joske Company and the homes were slowly replaced by black-topped parking lots. Only a few rooming houses survived in the Bonham-Bowie-Crockett area, and Commerce Street was fully commercial with businesses like Staffel's Feed and the Fairmount Hotel. The town, in general, had developed on the basis of mercantile, military, and distribution with almost no industry and little base from which it could develop. These elements created a prosperous, stable, but stagnant culture during the first 15 years of the new century. As a consequence, the metropolitan complex to the north at Dallas-Ft. Worth, and the chemical center at Houston began to seize the financial reins of the state.

The catalyst for the final factor to bring San Antonio fully into the modern world was the advent of World War I. In 1910 Lt. Benjamin Foulois was assigned to Fort Sam Houston to initiate aviation operations in Texas's favorable weather. He brought with him the sole airplane owned by the Army-a canvas and wooden Wright Flyer-with instruction to "teach yourself to fly" (Foulois, personal communication 1963). With the well-established base of Fort Sam Houston as a center, San Antonio became the prime training area for all of the services, with the development of Kelly and Brooks airfields, and Camp Bullis. During the war, the city served as host for the training of more than 250,000 infantry men and flyers.
During the 1920 s, the city continued to grow. For a short time it was the expatriate home for 25,000 wealthy refugees from the Mexican Revolution, served as the capital for the exile government, and became the permanent home of thousands of their citizens. San Antonio served as the center for the Mexican presence north of the border (Fehrenbach 1978:169).

In September 1921, San Antonio experienced another of its devastating floods with a loss of 49 dead, 14 missing, and an estimated $\$ 8,000,000$ in property damage (Corps of Engineers 1972:5). This event at last spurred positive action to correct the recurring hazard to its population and property. Channel improvements, construction of the Olmos retention dam, and creek widening vastly improved, but did not entirely solve, flooding within the city. Further improvements to the drainage problems of the city are still ongoing.

By 1930 the population had reached 231,542 and the city realized dangers that progress posed to its historic heritage, an awakening that stirred a multi-faceted effort to save and preserve its past. Some of the results of these efforts are San Antonio's major tourist attractions of today: The River Walk, La Villita, the Spanish Governor's Palace, and the Spanish missions. The national depression caused a long period of stagnation that settled upon the agrarian sector, depressed business, and drastically cut into the military spending to which San Antonio had grown so accustomed. During this period, and for the following decade, the city slumbered, while Dallas took charge as the financial capital and Houston exploited its mineral riches, and both surged ahead of San Antonio (Fehrenbach 1978:173). This hiatus was broken by the nation's entry into World War II, and again military activity revived the economy and enthusiasm of the city. After the war, the city began to realize that without an industrial base, a reliable source of money must be sought. Today the city relies predominantly on a joint base of tourism, military, and light industry while constantly searching for other avenues to maintain its prominence. 


\section{Part II: The Sites}

\section{Introduction}

Each chapter presented here describes the entire investigation of one city block. The chapters are organized into the following parts: a history of the site and its ownership, a complete description of the archaeological investigations, an analysis of the artifacts recovered, and a discussion of the results and conclusions that could be made about the relationship of the artifacts to the various residents of the sites.

\section{Contents}

Chapter 5. The Degen House

Chapter 6. The Tengg Site

Chapter 7. The Mueller House

Chapter 8. The Vanderstratten Site

Chapter 9. The Faska Site

Chapter 10. The Battaglia Site

Chapter 11. The Kissling Site

Chapter 12. The Ludlow House and Moody Site

Chapter 13. The Fischer Site

Chapter 14. The Palm House

Chapter 15. Searching for The. Funeral Pyre

Chapter 16. Moving the Fairmont Hotel 


\section{Chapter 5: The Degen House and Brewery}

Site Identification: Degen Residence, NCB 166 Lots 10 and 97

Address: 237-239 Blum

Trinomial: $41 B X 632$

\section{Historical Background}

The initial wave of German immigration to Texas included a number of singularly unique and talented individuals who united to escape the loosely knit German confederation of the time. Among these industrious emigrants was Charles Philip Degen who, through his dedication to his craft, established a world-acclaimed business within the area. Born in Baden, Mannheim, Germany on January 14,1825 , and formally trained as both a cooper and a brewer, Degen immigrated to Texas in 1850 (Kohler 1984). Upon his arrival he made his way to San Antonio and then on to Castroville on the Medina River. Degen engaged in farming in that settlement for two years, but left to pursue the gold rush in California where he stayed for two years. He spent a brief time in South America where he may have bee involved with the construction of the Panama Railroad before returning to Texas in 1855 (Chabot 1937:410; Hagner 1940:74; McCullough 1977:33).

Degen was now a man of 30 and ready to settle down. Upon his arrival in San Antonio, he gained employment with another first-generation German-Texan, William Menger. Menger, also a brewer and cooper, realized that his newly established hotel on Alamo Plaza needed a ready supply of good beer to satisfy his largely German clientele. In 1856 he engaged Degen to assist him in the brewery he had begun in the basement of the hotel (B. Woolford and S. Woolford ca. 1950:65), a suitable facility for producing beer that was cooled by the old acequia flowing through the structure (Ramsdell 1945). In very short time Degen was fully in charge of the operation, producing brew deemed by the United States health department as "the healthiest beer in the country," and proclaimed a "cure for tuberculosis" (Ramsdell 1945). The beer produced was a special secret formula de- vised by Degen using such quality ingredient as imported hops from California and Ireland, transported into the city by way of the port of Indianola. The brewery's fame spread rapidly, and by the 1870 s over 3,000 pounds of staves per year were require to produce the beer barrels needed (Woolford 1959). Menger died in March 1871, and Degen continued to operate the brewery for Menger's widow.

Meanwhile, in 1860, Degen had married 21-year-old Elizabeth Fink (Kohler 1984). In 1868 Degen bought a double lot on Crockett Street from Thomas and Tabitha Grayson (BCDR U2:442). The Degens lived in a small adobe house which had been built by the previous owner in ca. 1855 on the west half of the lot and hired J. H. Kampmann to build them a one-story stone house on the other half. The new house at 348 Crockett Street was completed in 1869 (Figure 5-1). The house remained in the family with little alteration except the addition of front and rear porches sometime before 1892, and a small bathroom on the back ca. 1904 (Sanborn Maps).

In the same year the house was finished, Degen also bought two lots on Blum Street from Tabitha Grayson (BCDR, U2:473). The property at 237-239 Blum Street backed Degen's house lot on Crockett Street (Figure 5-2), giving the Degens a strip of property running the full width of the city block. The house faced on Crockett Street with a garden area behind the house. To the east of the house was a large vacant lot (Kohler 1984). The Blum Street property later held the brewery which faced on Blum Street and shared the garden with the house. The brewery was not built until nine years after the purchase of the property, and the lot appears to have remained vacant until that time.

Charles and Elizabeth had eight children, seven of whom survived into adulthood (Kohler 1984). The 
Degens were active and popular members of the German community. A founding member of the Kronken Kassen Verein (San Antonio Beneficiary Association), Charles Degen also belonged to many other neighborhood organizations including the volunteer firemen, the Odd Fellows, the Beethoven Mannerchor, and the San Antonio Turn Verein (Degen Obituary, $S A E$, Feb. 8, 1912).

In 1878 Degen opened a brewery and beer garden on the Blum Street property. He purchased Menger's brewing equipment and continued to brew his popular beer (Bechtol 1984). The small, El-shaped stone structure at 239 Blum was a typical Texas vernacular building with an entrance on the western portion framed by two shuttered windows (Figure 5-3). The single entrance led to a long bar room where the drinks were served. To the right, a short flight of steps led to the room where the beer was produced and from this room steps led down into the cellar beneath the bar (Figure 5-4) where the vats were stored. The vats were located toward the back and overhead. To the rear of the brewery a wooden porch and grape arbor had been added. Under the vine-covered arbor were long, roughhewn tables and benches where the ladies were served; they were never permitted inside the bar room. On the western end of the porch a small kitchen and bath were constructed later (Kohler 1984; oral history interview).

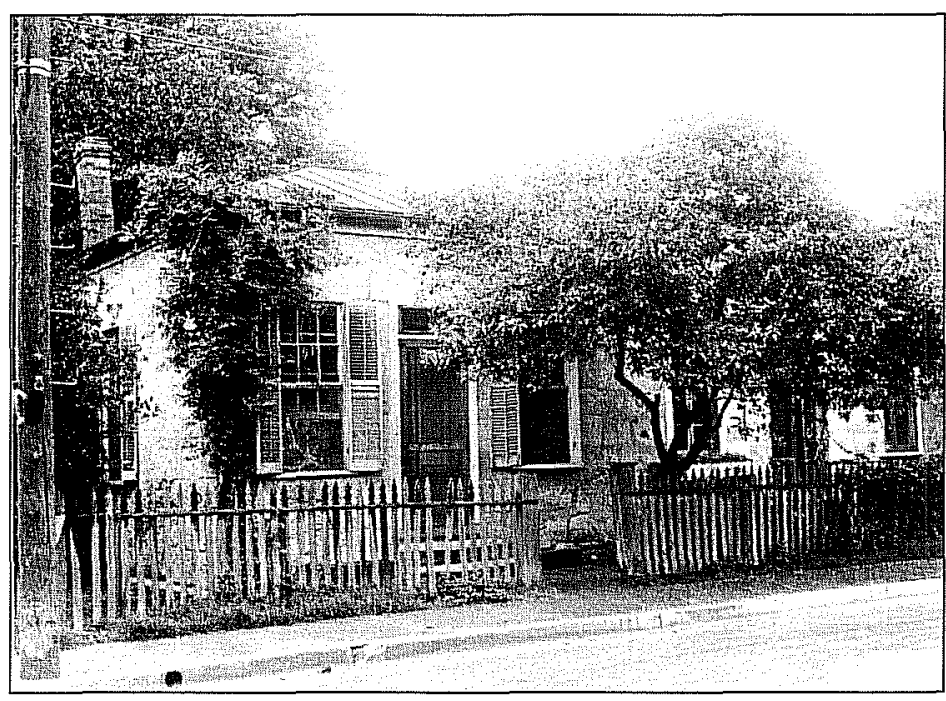

Figure 5-3. Degen Brewery

(DRT Library).

Figure 5-4. Interior basement of Degen Brewery ca. 1890 (DRT Library).

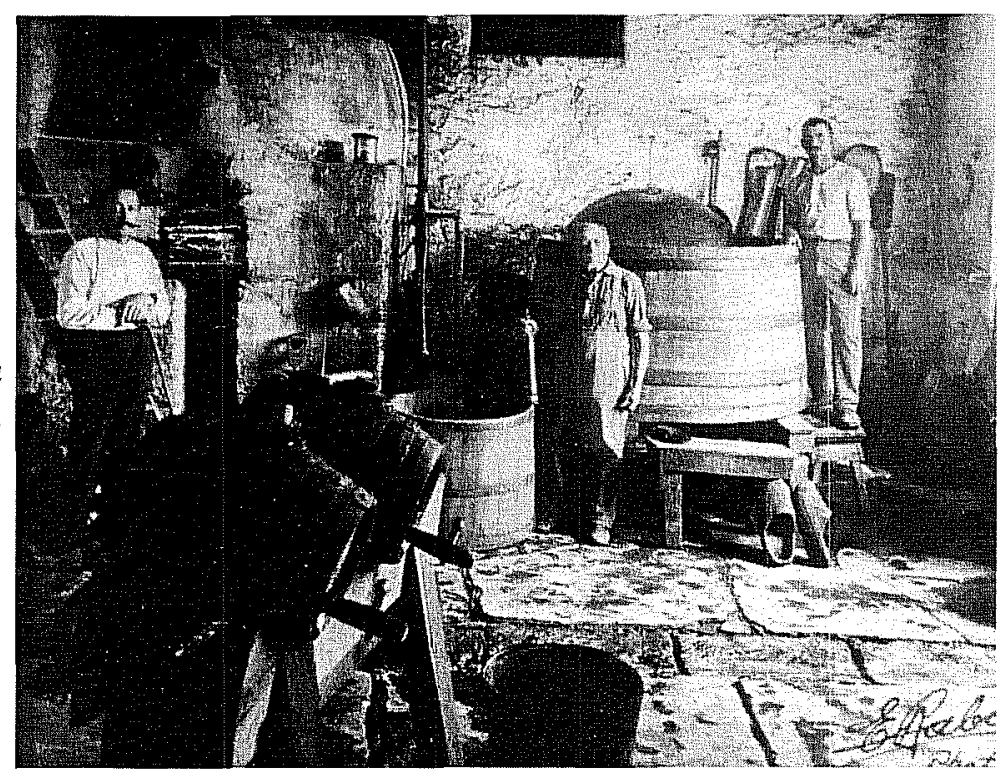




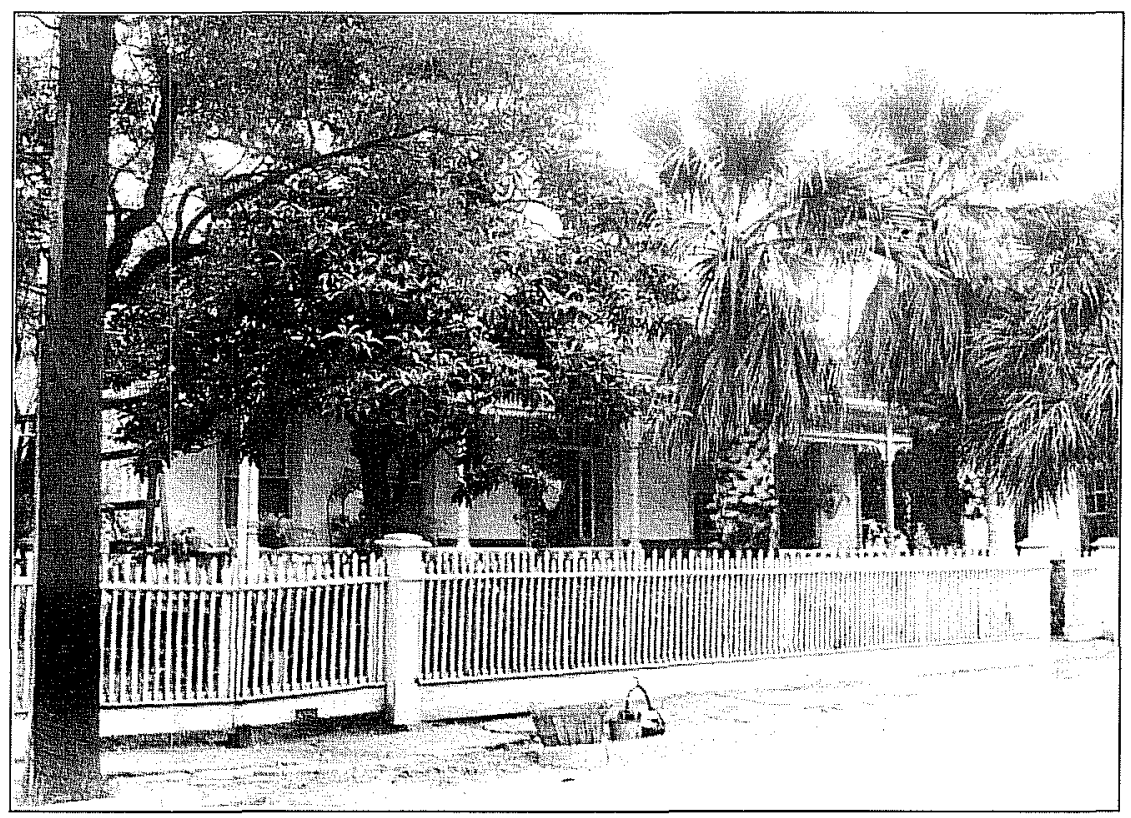

Figure 5-1. Charles Degen House (DRT Library).

Figure 5-2. Location map of Degen and Mueller sites.

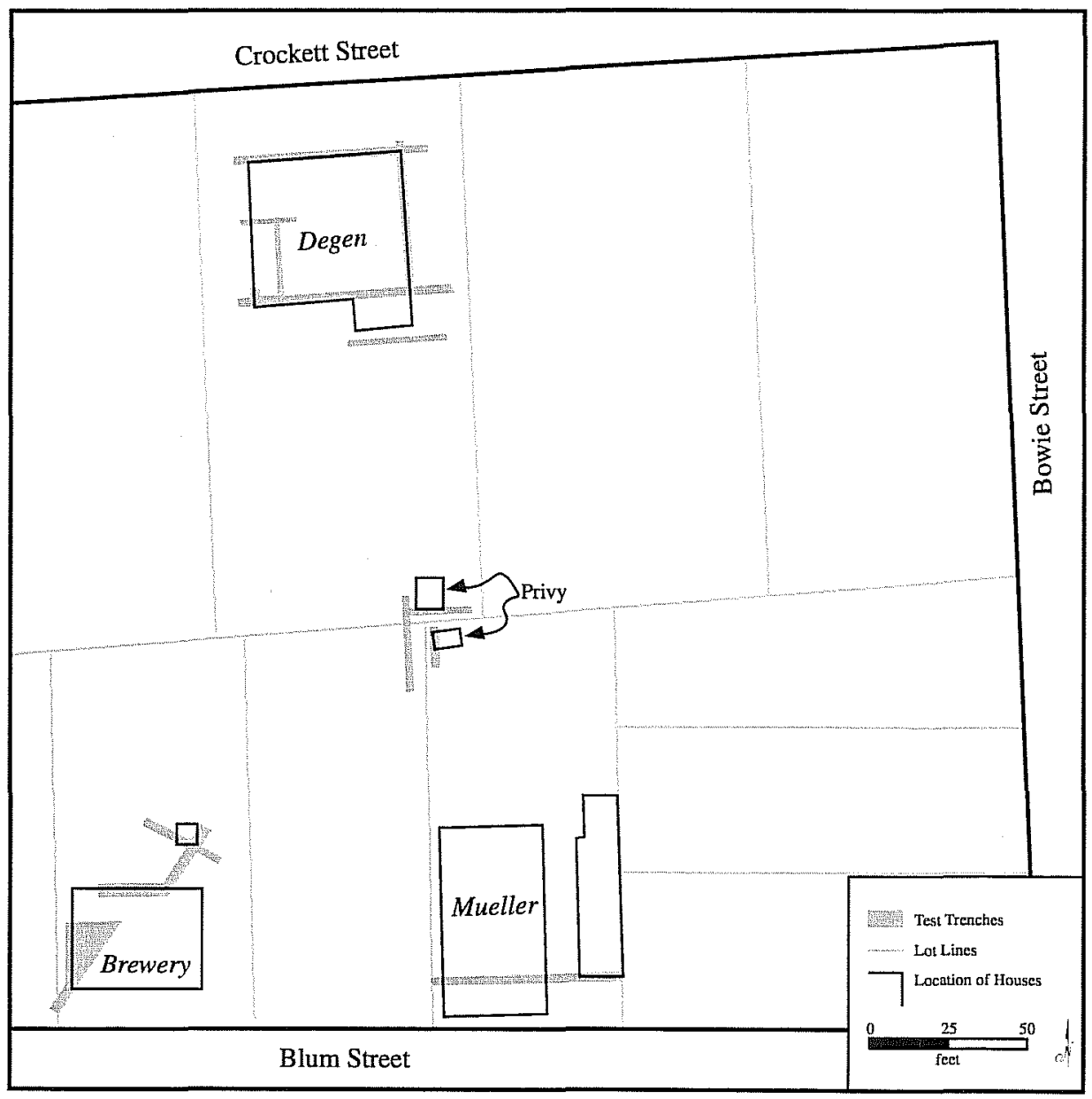


At the close of the Spanish-American War in 1898, Charles W. Degen, Charles's youngest son, returned to San Antonio and joined his father in the operation of the brewery. He had served as a member of Company F, First Texas, proudly know as the "Belknap Rifles." The beer they produced was acknowledged as one of the finest in the nation; they never produced it in volume, however, preferring instead to maintain a small output for the satisfaction of their loyal clientele at the small establishment on Blum Street. Their output never exceeded two barrels a day. In 1904 Degen's beer received the first place medal at the International Exposition in St. Louis.

In 1910 the Degens celebrated their fiftieth wedding anniversary at their home on Crockett Street near the brewery. Two years later, on February 8 , Charles Philip Degen died at the advanced age of 87 . His son Louis continued to operate the brewery until 1919 when prohibition forced the closure of the pioneer business.

The Degen family-Louis, Lena, and Katycontinued to live in the family home until 1921 when they sold the estate. They were later forced to reclaim the property due to non-payment. After the death of Louis in 1935, the sisters rented a home in the King William district on Guenther Street. In 1953 the Joske Company purchased the property and razed the structure for a parking lot.

Mary Winkler rented the brewery as a residence in 1921, followed by Mrs. F. M. Montez in 1927. The building was used commercially again in 1934 by the Ostrander Restaurant which stayed until 1938, although it may have been known as the "Wit's End Tea Room" for a short time (Yelton 1936). C. F Anderson rented the building in 1938 and the Works Progress Administration took it over in 1942, calling it the St. Mark's community house. This building was again a restaurant, the Spanish Village Cafe, in 19.46 (City Directories 1939-1946). It stood vacant until 1958 when it was bought, torn down, and paved over by the Service Parking Company.

\section{Archaeological Investigations}

\author{
Testing of the House
}

Eight backhoe trenches were excavated across the foundation wall of the Degen house to examine and record the construction methods used (Figure 5-5). The top of the remaining foundation was $17-19$ inches below the top of the asphalt paving of the parking lot. A possible fireplace base was found in the estimated center of the room in the northeast corner of the house, probably the living room.

The foundations of the house were substantially constructed, two feet wide, of shaped limestone with larger stones at corners and occasionally along the wall lines. A two-inch footing of limestone rubble was laid in the wall trench, upon which the foundations were laid up with soft sand as mortar. The stones that formed the chimney base were larger than those in the rest of the foundations, and projected ca. 12 inches from the inner wall line.

A very small addition (ca. $6 \times 6.5 \mathrm{ft}$ interior measurements) at the southeast corner on the back of the house enclosed a bathroom which was added before 1904 (Sanborn Insurance Maps). The construction of the foundation was similar to that of the house, except for the use of smaller in-filling stones in the more recent foundation. This foundation was only 18 inches wide.

\section{Testing of the Brewery}

Six backhoe trenches (Figure 5-6) were excavated across the foundation walls of the brewery (north-south trenches 1 to 3, east-west trenches A to C). Trench 1 , a diagonal trench across the southwest corner, exposed the west basement wall line, then was expanded to include about two-thirds of the wall and was extended down to the basement floor at eight feet below the surface of the parking lot. The floor was paved with sandstone slabs. The outside of the wall was dressed with cement and the inside with plaster. A cedar post was found in association with the front corner of the building, and later in Trench B a similar one was found 


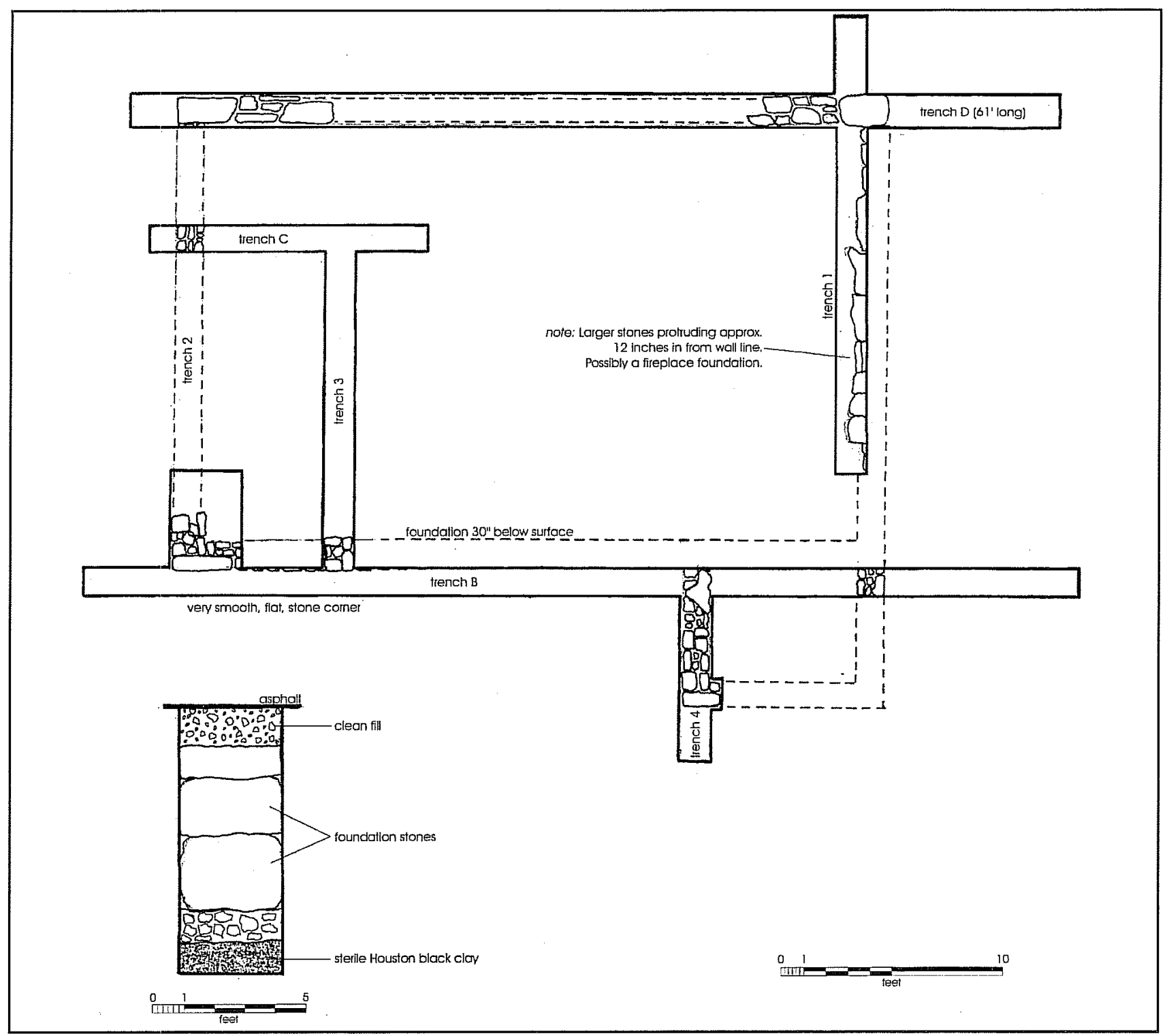

Figure 5-5. Plan of test trenches at the Degen home.

at the opposite front corner. The presence of these posts suggests that the building once had a front porch. Since pyramidal roofs did not become popular until the early twentieth century (Fox 1997) this may indicate an episode of remodeling at that time.

There was a distinct change in the type of construction of the top 8-10 inches of the wall, probably the first course of the part that projected above ground. Trench A revealed a carefully constructed light well near the top of the north wall, which is clearly visible in the photograph of the basement (Figure 5-4). The lower part of the basement fill consisted of limestone rubble from the demolition of the building. However, it appears that it was necessary to bring fill in from elsewhere to finish the job, for the top portion consisted of broken red and yellow bricks in cement mortar, some of which were painted yellow, and fragments of wooden columns, also yellow. This upper fill also contained numerous sheets of corrugated roofing and a truck tire made in Mexico.

Additional test trenches in the area behind the building revealed a confused tangle of buried pipe lines interspersed with flagstone paving which probably covered a back porch or patio area. Additional trenching in the area at a later date did nothing to clear up the confusion and the attempt was abandoned. 


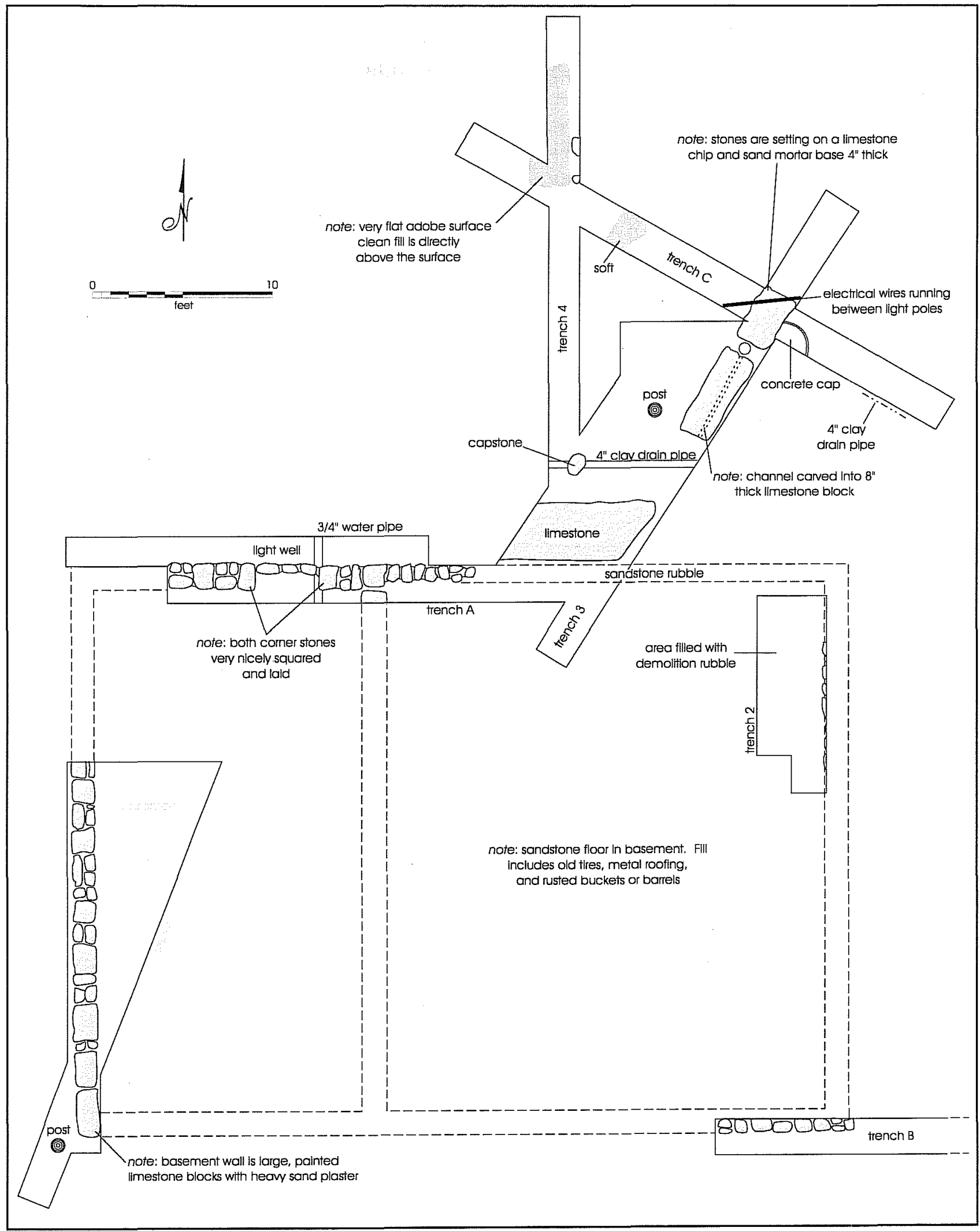

Figure 5-6. Plan of test trenches at Degen Brewery. 


\section{Testing to Locate the Acequia and the Privy}

Testing at the back of the lot in an unsuccessful attempt to locate a branch of the acequia revealed instead the stone outline of a privy pit in the extreme southeast corner (Figure 5-7). This feature was excavated in the second phase of the investigations.

\section{Excavation of the Privy (Feature IB)}

The privy, assigned the field designation Feature IB, measured 43 inches by 59 inches and was excavated to a maximum depth of 131 inches. It was excavated by stratigraphic levels as indicated by observed changes in soil color and texture. Fifteen levels were identified, excluding a surface preparatory level. There was a tendency, however, to over-identify soil changes in the field, a problem corrected in the following account of the excavations. The north and south walls of the privy were constructed of large, cut limestone blocks, while limestone rubble was used in the east and west walls.

The original mitigation plan was to excavate only the eastern portion of the feature and to leave the western portion intact for recording the profile. To comply with OSHA regulations, however, after recording the west profile at about the four-foot depth, the western half of the privy was removed to that depth and the feature was excavated from a wide, exterior backhoe trench dug perpendicular to the west wall of the privy, removing the wall as the excavations progressed down. The recorded profile (Figure 5-8) is a combination of the results of these two stages of excavation.

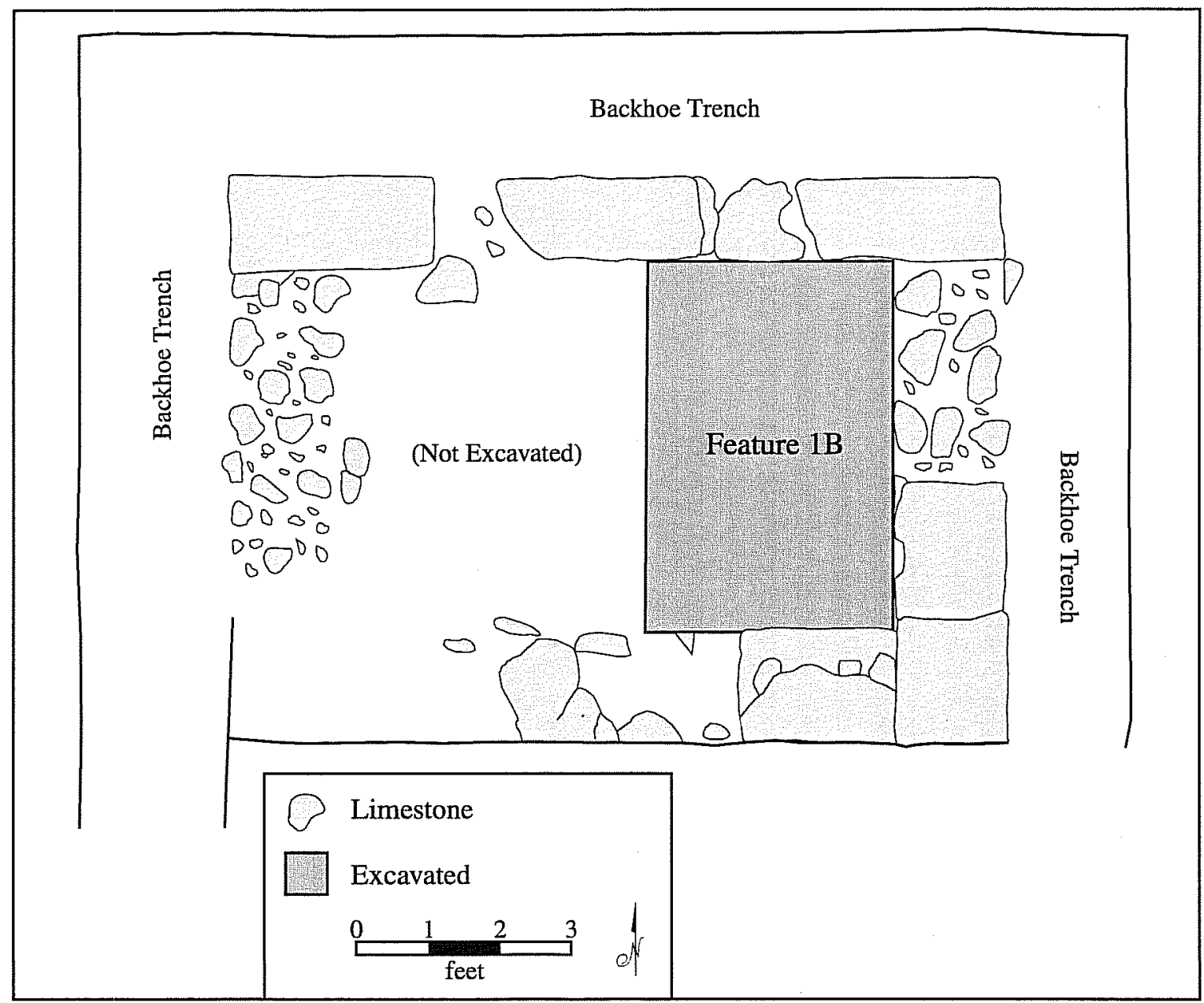

Figure 5-7. Plan of Degen privy as located by testing. 


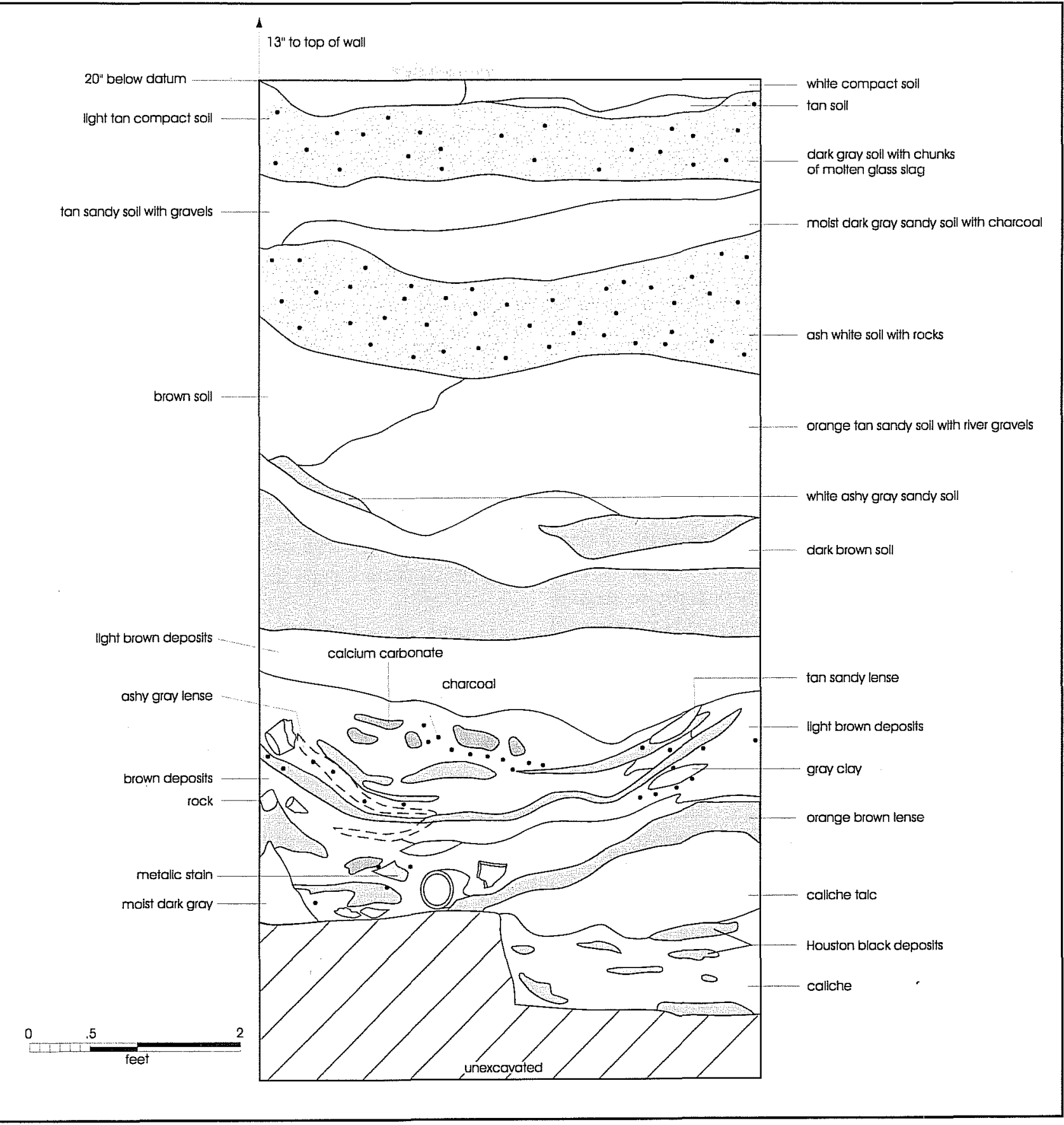

Figure 5-8. Section through Degen privy, looking east. 
More than 6,402 artifacts were recovered from the privy. Table $5-1$ presents all the artifacts, sorted by artifact/activity class and vertical provenience. Because so few temporally diagnostic artifacts were recovered from the privy, the individual levels are described below to assist in identifying depositional episodes. Our analysis assumes multiple depositions can be detected through differences in soil color and texture and a simultaneous examination of the artifacts. Three deposits could conclusively be discerned: Levels 1 through 5 appeared to be a single, redeposited unit as these levels contained large amounts of slag, coal, and clinker and were comprised mostly of construction and shop artifacts. The deposit appeared to be secondary as there was no evidence of fire reddened earth or burned walls. The second deposit was a gray ashy layer extending from Level 8 through Level 14 . The ash was observed only in the south-southeastern portion of these levels. However, because the artifacts were collected by levels, there is no way to examine the artifacts from the southern portion separately. Levels 11 and 12, consisting of limestone gravel fill, also appeared to be a single depositional unit. Descriptions of the excavation levels follow.
Level 1 was a dark grayish brown sandy clay with a moderate amount of plaster and mortar (representative samples of each were collected) and a small amount of slag and clinker. The artifact counts from the level were small $(n=150,2.34$ percent of all artifacts collected from the feature). Barn/workshop and construction artifacts constituted approximately 94 percent of the artifacts collected from the level.

Level 2 was a brown sandy clay with large amounts slag, coal, and clinker. Few artifacts were recovered from the level ( $n=151,2.35$ percent) and approximately 84 percent were either construction or barn/shop.

Level 3 was a dark gray sandy clay with construction rubble and large amounts of slag, coal, and clinker. Few artifacts ( $n=148,2.3$ percent) were recovered from this level. The rest of the artifacts ( 71 percent) were construction or shop artifacts.

Level 4 was a dark brownish-gray clay level with burnt materials, but less than what was observed in previous layers. Level 4 contained the second lowest number

Table 5-1. Artifacts from Degen Privy

\begin{tabular}{||c|c|c|c|c|c|c|c|c|c|c|c|c||}
\hline Level & ceramics & glass & kitchen & bone & furnish. & clothing & personal & activity & barn & arms & construction & Total \\
\hline surface & 30 & 196 & 0 & 166 & 10 & 5 & 2 & 7 & 7 & 0 & 93 & 516 \\
\hline 1 & 2 & 4 & 0 & 0 & 1 & 2 & 0 & 0 & 42 & 0 & 99 & 150 \\
\hline 2 & 2 & 10 & 0 & 7 & 1 & 1 & 1 & 0 & 14 & 0 & 115 & 151 \\
\hline 3 & 6 & 18 & 0 & 4 & 5 & 3 & 0 & 0 & 16 & 0 & 96 & 148 \\
\hline 4 & 3 & 14 & 0 & 0 & 0 & 0 & 0 & 0 & 38 & 0 & 30 & 85 \\
\hline 5 & 13 & 35 & 0 & 0 & 2 & 6 & 0 & 2 & 3 & 0 & 80 & 141 \\
\hline 6 & 30 & 93 & 0 & 281 & 14 & 7 & 1 & 0 & 9 & 0 & 384 & 819 \\
\hline 7 & 32 & 165 & 0 & 608 & 2 & 11 & 0 & 3 & 11 & 0 & 355 & 1187 \\
\hline 8 & 2 & 37 & 0 & 48 & 2 & 3 & 0 & 0 & 51 & 0 & 35 & 178 \\
\hline 9 & 14 & 55 & 0 & 133 & 3 & 5 & 0 & 3 & 10 & 0 & 214 & 437 \\
\hline 10 & 20 & 115 & 0 & 145 & 2 & 2 & 1 & 1 & 5 & 1 & 187 & 479 \\
\hline 11 & 9 & 19 & 0 & 105 & 1 & 1 & 3 & 1 & 8 & 1 & 73 & 221 \\
\hline 12 & 5 & 48 & 0 & 363 & 0 & 13 & 0 & 0 & 0 & 0 & 56 & 485 \\
\hline 13 & 94 & 291 & 1 & 269 & 12 & 39 & 2 & 1 & 1 & 0 & 5 & 715 \\
\hline 14 & 61 & 126 & 0 & 457 & 35 & 5 & 1 & 0 & 0 & 0 & 3 & 688 \\
\hline 15 & 0 & 2 & 0 & 0 & 0 & 0 & 0 & 0 & 0 & 0 & 0 & 2 \\
\hline Total & 323 & 1228 & 1 & 2586 & 90 & 103 & 11 & 18 & 215 & 2 & 1825 & 6402 \\
\hline$\%$ of \\
Total
\end{tabular}


of artifacts ( $n=85,1.32$ percent) recovered from the feature. Eighty percent of the artifacts were construction or shop.

Level 5 was a dark gray sandy clay with construction debris (rubble, mortar, and plaster) and less slag than other layers. In fact, the slag stopped in this level. Fistsized gravel was recorded in the bottom of the level. One hundred thirty-nine artifacts were recovered (2.17 percent), 59.7 percent of which were construction or shop.

Level 6 was a gray sandy clay with chert and limestone gravel fill and construction debris. The level contained substantially more domestic artifacts (i.e., ceramics and bottle glass sherds) and total artifacts ( $n=819$, 12.79 percent) than the above levels. The largest artifact/activity type encountered in the level, however, was again construction and shop artifacts $(n=393$, 47.98 percent for the level). Thirty ceramic sherds were recovered, representing 3.66 percent of all artifacts recovered from the level and 9.29 percent of the total (privy) ceramic assemblage. Ninety-three bottle glass sherds accounted for 11.35 percent of artifacts from the level, but constituted only 7.57 percent of the entire bottle glass assemblage. The first significant deposit of (animal) bone was also recovered in Level 6 ( $n=281,34.31$ percent). Level 6 actually had the third largest bone count in the entire privy (accounting for approximately 10.91 percent of the bone assemblage).

Level 7 was a mottled dark gray and tan clay with gravel and pebble inclusions. The level contained more artifacts than any other level in the privy $(n=1,187$, 18.56 percent of all artifacts recovered from the privy). The largest deposit of animal bone was also observed in this level $(n=608,51.18$ percent of all artifacts from the level, 23.61 percent of privy's bone assemblage). Construction and shop artifacts comprised 30.81 percent $(n=366)$ of all artifacts recovered from the level. One hundred sixty-five bottle glass sherds were also recovered, representing 13.89 percent of all artifacts from the level and 13.44 percent of the total glass assemblage. Ceramics accounted for only 2.78 percent $(n=33$ ) of the artifacts from the level although this represents 10.22 percent of the entire ceramic assemblage.
Level 8 was excavated as an arbitrary level. The unit had been flooded and the excavators removed a 10 inch mud level. A total of 177 artifacts (2.76 percent of all artifacts recovered from the privy) was recovered from the level. The largest artifact/activity type was again construction and shop artifacts $(n=86,48.59$ percent). Slightly more than 27 percent of the level was comprised of animal bone $(n=86)$; however, this represents less than 2 percent of the entire bone assemblage. Very small amounts of ceramics $(n=2$, 1.13 percent of artifacts from level, 0.62 percent of ceramic assemblage) and bottle glass $(n=37,20.90$ percent of artifacts from level, 3.01 percent of total glass assemblage) were also recovered from the feature.

The northern portion of Level 9 was a dark grayishbrown clay with construction rubble, while the aforementioned gray ashy deposit first appeared in the southern portion of the level. The level contained 437 artifacts which accounts for about 6.82 percent of all artifacts recovered from the privy. Most of the artifacts were either construction or shop $(n=224,51.26$ percent of all artifacts from the level) or animal bone fragments ( $n=133,30.43$ percent).

Three soil types were identified in Level 10: a tan sandy clay in the western portion of the unit, the gray ashy layer continued in the southern portion, and a grayish-brown clay was observed in all other portions of the level. Despite the soil differences, gravel, limited amounts charcoal, wood, and brick rubble were distributed throughout the level. Four hundred seventynine artifacts were recovered from the level, accounting for 7.48 percent of all artifacts recovered from the feature. Large amounts of construction and shop artifacts $(n=197,40.08$ percent of the artifacts recovered from the level), bottle glass sherds $(n=115$, 24 percent), and animal bone fragments $(n=145,30.27$ percent) were recovered.

The western wall partially collapsed before Level 11 was excavated. Consequently, the entire western wall was removed. Excavation of the unit resumed in the eastern portion of the unit. Except for the gray ashy layer in the southeastern portion of the unit, Level 11 was comprised of gravel fill. The level contained a fairly light deposit of artifacts ( $n=217,3.38$ percent). 
Construction and shop artifacts $(n=81,37.33$ percent of all artifacts excavated from the level) and animal bone fragments ( $n=105,48.39$ percent) were the most frequently observed artifacts.

Level 12 appears to be a continuation of the gravel fill identified in Level 11. Pea gravel suspended in a fine light brown sand was recorded in the excavation notes. Level 12 contained substantially more artifacts ( $n=485,7.57$ percent of all recovered artifacts) than Level 11, however. The composition of the artifacts by type also varies considerably. Animal bone fragments $(n=363)$ accounted for 74.85 percent of all of the artifacts excavated from the level. Bottle glass sherds $(n=48,9.90$ percent $)$ and construction and shop artifacts $(n=56,11.55$ percent) were the next most frequently observed artifacts.

Level 13 was a mottled tan and brown clay with some charcoal inclusions. The gray ashy layer continued in the southern portion of the unit. The level contained the third highest number of artifacts in the privy ( $n=715,11.16$ percent). The level contained surprisingly high amounts of domestic artifacts. Ninety-four ceramic sherds were recovered, which represents only 13.15 percent of the artifacts recovered from the level, but represents 29.10 percent of the entire ceramic assemblage. Large quantities of bottle glass were also excavated from the level $(n=291,40.70$ percent of all artifacts recovered from level, 23.70 percent of bottle glass assemblage). The greatest number of clothing artifacts was also recovered from Level $13(n=39,5.45$ percent of artifacts recovered from level, and 18.45 percent of the entire clothing assemblage).

Level 14 was a grayish brown silty clay with some large charcoal inclusions and metal stains. The gray ashy layer continued into the southern portion of the level. The level contained 688 artifacts accounting for 10.74 percent of all artifacts recovered from the feature. Animal bone fragments account for 66.42 percent $(n=457)$ of all artifacts recovered from the level. Again, a high ceramic count was recorded for the level $(n=61$, 8.87 percent of all artifacts recovered from the level, 18.89 percent of the ceramic assemblage). Bottle glass sherds represented 18.31 percent of the artifacts recovered from the level $(n=126)$. There were few construction and shop artifacts recovered from the level $(n=3,0.44$ percent of artifacts recovered from the level). Level 15 was the beginning of the caliche floor level. Only two fragments of bottle glass were recovered.

We examined changes in the artifactual composition of the levels (Table 5-2) and similarities and dissimilarities in artifact type distribution by level (Table5-3). Table 5-2 presents the percent of the entire assemblage for each artifact type by level (i.e.,

Table 5-2. Degen Privy Artifact Percentages by Level

\begin{tabular}{||c|c|c|c|c|c|c|c|c|c|c|c|c||}
\hline Level & ceramics & glass & kitchen & bone & furnish. & clothing & personal & activity & barn & arms & construction \\
\hline surface & 10.84 & 15.96 & 0.00 & 6.42 & 11.11 & 4.85 & 18.18 & 38.89 & 3.26 & 0.00 & 5.10 \\
\hline 1 & 0.62 & 0.33 & 0.00 & 0.00 & 1.11 & 1.94 & 0.00 & 0.00 & 19.53 & 0.00 & 5.42 \\
\hline 2 & 0.62 & 0.81 & 0.00 & 0.27 & 1.11 & 0.97 & 9.09 & 0.00 & 6.51 & 0.00 & 6.30 \\
\hline 3 & 1.86 & 1.47 & 0.00 & 0.15 & 5.56 & 2.91 & 0.00 & 0.00 & 7.44 & 0.00 & 5.26 \\
\hline 4 & 0.93 & 1.14 & 0.00 & 0.00 & 0.00 & 0.00 & 0.00 & 0.00 & 17.67 & 0.00 & 1.64 \\
\hline 5 & 3.41 & 2.85 & 0.00 & 0.00 & 2.22 & 5.83 & 0.00 & 11.11 & 1.40 & 0.00 & 4.38 \\
\hline 6 & 9.29 & 7.57 & 0.00 & 10.87 & 15.56 & 6.80 & 9.09 & 0.00 & 4.19 & 0.00 & 21.04 \\
\hline 7 & 10.22 & 13.44 & 0.00 & 23.51 & 2.22 & 10.68 & 0.00 & 16.67 & 5.12 & 0.00 & 19.45 \\
\hline 8 & 0.62 & 3.01 & 0.00 & 1.86 & 2.22 & 2.91 & 0.00 & 0.00 & 23.72 & 0.00 & 1.92 \\
\hline 9 & 4.33 & 4.48 & 0.00 & 5.14 & 3.33 & 4.85 & 0.00 & 16.67 & 4.65 & 0.00 & 11.73 \\
\hline 10 & 6.19 & 9.36 & 0.00 & 5.61 & 2.22 & 1.94 & 9.09 & 5.56 & 2.33 & 50.00 & 10.25 \\
\hline 11 & 1.55 & 1.55 & 0.00 & 4.06 & 1.11 & 0.97 & 27.27 & 5.56 & 3.72 & 50.00 & 4.00 \\
\hline 12 & 1.55 & 3.91 & 0.00 & 14.04 & 0.00 & 12.62 & 0.00 & 0.00 & 0.00 & 0.00 & 3.07 \\
\hline 13 & 29.10 & 23.70 & 100.00 & 10.40 & 13.33 & 37.86 & 18.18 & 5.56 & 0.47 & 0.00 & 0.27 \\
\hline 14 & 18.89 & 10.26 & 0.00 & 17.67 & 38.89 & 4.85 & 9.09 & 0.00 & 0.00 & 0.00 & 0.16 \\
\hline 15 & 0.00 & 0.16 & 0.00 & 0.00 & 0.00 & 0.00 & 0.00 & 0.00 & 0.00 & 0.00 & 0.00 \\
\hline & $100.00 \%$ & $100.00 \%$ & $100.00 \%$ & $100.00 \%$ & $100.00 \%$ & $100.00 \%$ & $100.00 \%$ & $100.00 \%$ & $100.00 \%$ & $100.00 \%$ & $100.00 \%$ \\
\hline
\end{tabular}


Table 5-3. Degen Privy Artifact Percentages in Each Level

\begin{tabular}{||c|c|c|c|c|c|c|c|c|c|c|c|c||}
\hline \hline Level & ceramics & glass & kitchen & bone & furnish. & clothing & personal & activity & barn & arms & construction & total \\
\hline surface & 5.81 & 37.98 & 0.00 & 32.17 & 1.94 & 0.97 & 0.39 & 1.36 & 1.36 & 0.00 & 18.02 & $100.00 \%$ \\
\hline 1 & 1.33 & 2.67 & 0.00 & 0.00 & 0.67 & 1.33 & 0.00 & 0.00 & 28.00 & 0.00 & 66.00 & $100.00 \%$ \\
\hline 2 & 1.32 & 6.62 & 0.00 & 4.64 & 0.66 & 0.66 & 0.66 & 0.00 & 9.27 & 0.00 & 76.16 & $100.00 \%$ \\
\hline 3 & 4.05 & 12.16 & 0.00 & 2.70 & 3.38 & 2.03 & 0.00 & 0.00 & 10.81 & 0.00 & 64.86 & $100.00 \%$ \\
\hline 4 & 3.53 & 16.47 & 0.00 & 0.00 & 0.00 & 0.00 & 0.00 & 0.00 & 44.71 & 0.00 & 35.29 & $100.00 \%$ \\
\hline 5 & 9.22 & 24.82 & 0.00 & 0.00 & 1.42 & 4.26 & 0.00 & 1.42 & 2.13 & 0.00 & 56.74 & $100.00 \%$ \\
\hline 6 & 3.66 & 11.36 & 0.00 & 34.31 & 1.71 & 0.85 & 0.12 & 0.00 & 1.10 & 0.00 & 46.89 & $100.00 \%$ \\
\hline 7 & 2.70 & 13.90 & 0.00 & 51.22 & 0.17 & 0.93 & 0.00 & 0.25 & 0.93 & 0.00 & 29.91 & $100.00 \%$ \\
\hline 8 & 1.12 & 20.79 & 0.00 & 26.97 & 1.12 & 1.69 & 0.00 & 0.00 & 28.65 & 0.00 & 19.66 & $100.00 \%$ \\
\hline 9 & 3.20 & 12.59 & 0.00 & 30.43 & 0.69 & 1.14 & 0.00 & 0.69 & 2.29 & 0.00 & 48.97 & $100.00 \%$ \\
\hline 10 & 4.18 & 24.01 & 0.00 & 30.27 & 0.42 & 0.42 & 0.21 & 0.21 & 1.04 & 0.21 & 39.04 & $100.00 \%$ \\
\hline 11 & 4.07 & 8.60 & 0.00 & 47.51 & 0.45 & 0.45 & 1.36 & 0.45 & 3.62 & 0.45 & 33.03 & $100.00 \%$ \\
\hline 12 & 1.03 & 9.90 & 0.00 & 74.85 & 0.00 & 2.68 & 0.00 & 0.00 & 0.00 & 0.00 & 11.55 & $100.00 \%$ \\
\hline 13 & 13.15 & 40.70 & 0.14 & 37.62 & 1.68 & 5.45 & 0.28 & 0.14 & 0.14 & 0.00 & 0.70 & $100.00 \%$ \\
\hline 14 & 8.87 & 18.31 & 0.00 & 66.42 & 5.09 & 0.73 & 0.15 & 0.00 & 0.00 & 0.00 & 0.44 & $100.00 \%$ \\
\hline
\end{tabular}

of all ceramics recovered from the privy, less than 1 percent [0.62 percent] was found in Level 1). Some interesting generalizations can be inferred from these data. For instance, Levels 1 through 5 contained less than 10 percent of all artifacts recovered from the privy, but contained 27.78 percent of all construction artifacts and 55.81 percent of all barn/shop artifacts. Similarly, Levels 1 through 5 contained few domestic artifacts (i.e., ceramics, bottle glass, bone). Throughout most of the feature, levels that contained large amounts of domestic artifacts had few construction or shop artifacts and levels that had large amounts of construction and shop artifacts had lesser amounts of domestic artifacts. Table 5-3 illustrates this point well by providing percent of artifact types by level (i.e., ceramics accounted for 1.33 percent of all artifacts recovered from Level 1).

\section{Artifact Descriptions}

\section{Ceramics}

Three hundred twenty-three ceramic sherds were excavated from the privy. A majority of the ceramic assemblage was comprised of undecorated whiteware $(n=224,69,35$ percent of the total ceramics). Other privies in the Las Tiendas project area contained large amounts of undecorated toilet wares (i.e., chamberpots, wash basins, bath pitchers); with the exception of one complete chamberpot (Figure 5-9), however, all the identifiable undecorated whiteware sherds from the Degen privy were tablewares. Vessel form was identified for 67 rim sherds (29.91 percent of all undecorated whitewares). Forty of the rims (59.70 percent of the identified rims) were identified as plates of variable sizes. Twenty-two rims (32.84 percent) and a completely reconstructed cosmetic jar were recovered from the privy.

Thirteen maker's marks were observed and six were identified. The identified marks are described below by levels in ascending order.

An undecorated whiteware plate with "J. CLEMENTSON/HANLEY/STONE/ WARE" was recovered from Level 14. Godden (1964:150) believes that Joseph Clementson used this mark between 1839 and 1864 .

A saucer from Level 13 had the impressed mark "6/DAVENPORT/IRONSTONE/ HENDERSON AND GAINES 15-66." Godden (1971:65) suggests that Davenport used numerical representatives to indicate the date of manufacture. Thus, the saucer was probably produced in May 1866 . It should be mentioned that Henderson and Gaines, a New Orleans importer, was the American agent for the Davenport 


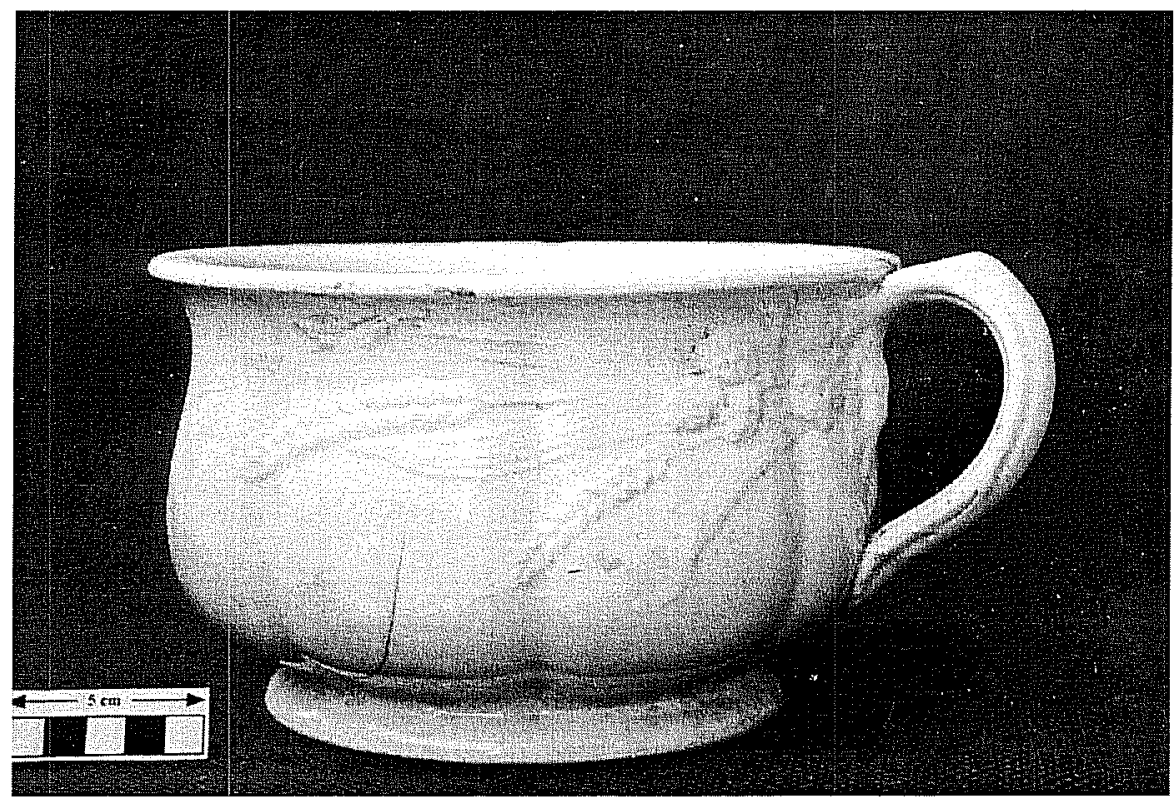

Figure 5-9. Chamber pot from Degen Privy.

Co. from 1836 until 1866 (Black and Brandimarte 1987). A second Davenport mark from Level 13 had an illegible British Registry Stamp, but was impressed with "9-69" (September 1869).Two mended sherds from an undecorated whiteware plate recovered from Level 13 were stamped and impressed with "STONE CHINA/GEORGE JONES/STOKE-UPON-TRENT." George Jones manufactured ceramics from 1864 until 1907 , but the particular mark probably dates to between 1861 and 1873 (Godden 1964:359).

Level 11 contained an undecorated whiteware sherd marked with "H \& CO./L/FRANCE" that has been identified as Haviland and Company of Limoges, France. Boger The Haviland family began manufacturing pottery in 1841 in Limoges. The firm continues in business today, several generations later (Ray 1974:86-7).

An undecorated whiteware sherd from Level 10 was marked with "BEST IRONSTONE CHINA/WARRANTED/CP Co." A similar mark was used by the Clyde Pottery Company of Scotland from 1850 until 1903 (Godden 1964:154).

An undecorated whiteware sherd from Level 10 was marked with "BEST IRONSTONE CHINA/WARRANTED/CP Co." A similar mark was used by the
Clyde Pottery Company of Scotland from 1850 until 1903 (Godden 1964:154).

An undecorated white-ware sherd from Level 10 was marked with "BEST IRONSTONE CHINA/WARRANTED/CP Co." A similar mark was used by the Clyde Pottery Company of Scotland from 1850 until 1903 (Godden 1964:154).

\section{Bottle Glass}

The second most frequently observed artifact was bottle glass. A total of 1,228 bottle glass sherds was identified. Fifty-two complete (4.23 percent of the glass assemblage) or mostly complete bottles (including reconstructed bottles) were recovered from Feature IB. Figure 5-10 illustrates a sample of this total.

Fourteen diagnostic bottle glass sherds were recovered. Unfortunately, only four of the sherds were temporally diagnostic.

A partial alcohol bottle from Level 13 was marked with "FHGW/6" on the base. Toulouse (1971:202) suggests that the Frederick Hampson Glass Works used this mark from ca. 1880 until 1900. One medicinal bottle from a local druggist was also recovered from Level 13.The bottle was marked with "A. NETTE JR/ DRUGGIST/SAN ANTONIO" which was in operation from 1877 to 1891 (City Directories).

Level 10 contained a clear alcohol flask marked with “A. SCHOLZ'S/PALM GARDEN/SALOON/SAN ANTONIO, TEXAS." The Palm Garden was operated from 1877 until 1891 (City Directories).

Level 7 contained a medicinal bottle marked with "W.D. Albini \& Co/315 Alamo Plaza/San Antonio, Tex." W.D. Albini \& Co. was in operation from 1895 until 1902 (City Directories). 


\section{Kitchenware}

The kitchenware artifact type/activity class may be comprised of pans, handles, and eating utensils. Unfortunately, the kitchenware group was the least represented in the privy $(n=1,0.002$ percent of all artifacts recovered from privy).In fact, only one spoon was recovered from Level 13.

\section{Animal Bone}

Animal bone fragments were the most ubiquitous

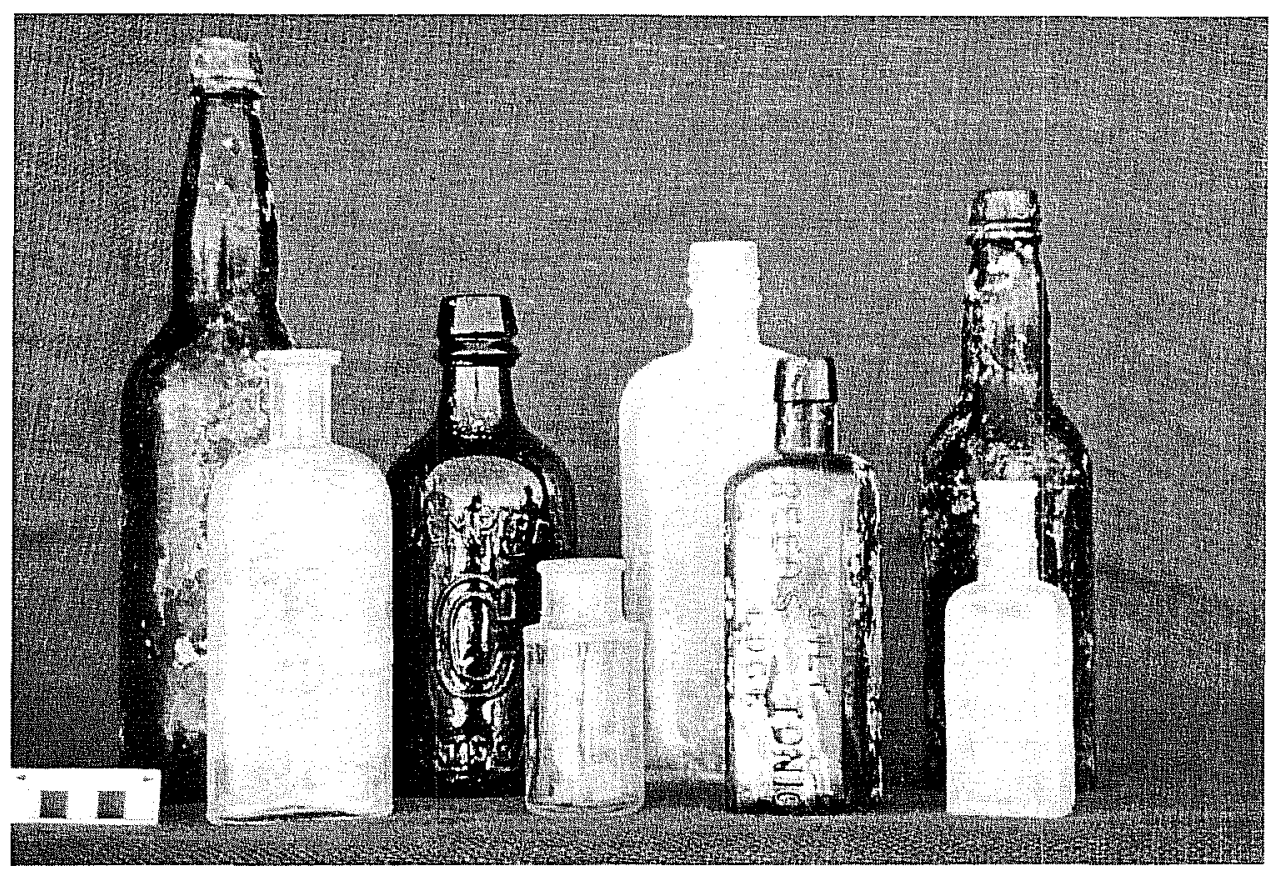

Figure 5-10. Sample of bottles from the Degen Privy. artifact recovered from the privy. Approximately 2586 bones were recovered, representing 40.28 percent of all artifacts recovered from the privy. For a more complete analysis of the faunal assemblage, please refer to Appendix A.

\section{Household Furnishings}

Ninety household furnishing artifacts were recovered representing 1.42 percent of all artifacts from the privy. The group contained a variety of items, the most common being chimney glass ( $n=67,74.44$ of all furnishing artifacts). The potential for over-representation of glass and, consequently, furnishings as a group must be considered. The other artifacts in the group included a door knob, a caster, a number of flower pot fragments, a portion of an iron, and an iron leg.

\section{Clothing}

The 103 clothing artifacts constituted 1.61 percent of all artifacts recovered. Of this number, 78 were buttons. Hooks/snaps, buckles, sewing items (mostly needles), and shoe parts were also recovered.

\section{Barn/Workshop}

Barn or workshop artifacts $(n=215)$ accounted for 3.36 percent of the entire assemblage. A great diversity of artifacts was collected, including wire, hoses, machinery parts, and a number of tools (chisels, trowel blades, and wrenches). 


\section{Arms}

Only a rifle cartridge and a partial gun stock were collected from the arms category. The arms assemblage represents 0.02 percent of all artifacts recovered.

\section{Construction}

The construction artifact type/activity class was the second largest. A total of 1,814 construction artifacts, representing 28.33 percent of the entire assemblage, was collected. The total count number is an approximation, however. Brick and mortar samples, for example, were counted irrespective of their relative size although it may have been more productive to have weighed them. Similar problems for quantifying window glass and partial nails also existed. Regardless, wire nails and window glass were the most frequently recovered construction artifact. Screws (of varying sizes) bolts, washers, nuts, brick, mortar, plaster, and wood were also collected.

\section{Utilities}

Eleven utilities artifacts were recovered $(0.17$ percent of all collected artifacts).The utilities artifacts consisted of five electric insulators and six sewer pipe fragments.

\section{Discussion}

The Degen family built and lived for many years in a modest stone house in a quiet residential neighborhood. Charles Degen lived within easy walking distance of his job assisting William Menger at the
Menger Brewery and later running the brewery himself. Degen did well enough in the brewery to be able to buy the property behind his home and build his own brewery there after the death of his former employer.

Judging by the artifacts recovered from the privy, the family lived a comfortable, middle-class life, with a minimum of ill health (few identifiable medicine bottles) and enough extra to occasionally afford to buy toys for the children. The comparatively large amount of nails, window glass, and bottle glass suggests that the family kept a clean, neat yard.

When Charles Degen died in 1912, his son Louis continued to operate the brewery until Prohibition. The family continued to live in the house until 1935 . When it was finally demolished, the house had not been appreciably changed from the way it looked when it was built in 1869, except for the addition of a bathroom. This suggests that the brewery, while popular and well known throughout the region, was probably not much of a money-making proposition. It also appears that the Degen family was quite satisfied with their middleclass status and felt no need to make changes or additions to their property.

The artifacts recovered from the lower levels of the privy pit (Levels 6-16) would have been in household use during the last quarter of the nineteenth century. On the whole, it appears they were deposited within a relatively short period of time. The larger percentage of bone in these bottom levels may indicate that garbage and trash were being deposited directly into the privy pit. The upper levels, which contained predominately construction and shop artifacts, may have been the result of yard cleaning and various minor construction projects on the site that were dumped into the pit to fill it up after the privy was no longer in use. 


\title{
Chapter 6: The Tengg Site
}

\author{
Site Identification: Tengg Residence, NCB 166 Lot 7 \\ Address: 326 East Crockett Street \\ Trinomial: 41BX633
}

\section{Historical Background}

When Thomas Tengg and his small family arrived in San Antonio in November 1852, the city was in the midst of a cultural transformation that marked the 1850 s as the city's pivotal decade of the nineteenth century. Tengg, a carpenter and furniture maker, was born January 1, 1810, in Himmelburg, Karnsten, Austria. The exact reason he chose to leave his homeland is unknown. Most likely he, along with his wife Eva and young son Nicolaus, decided to emigrate to Texas because of the economic and political conditions that gripped most of central Europe in the first half of the last century. Additional information regarding the Tengg family while in Austria is vague. The exact date of the marriage of Thomas to Eva, who was nearly six years his senior, is unknown. It is certain however that she presented him with their only child, Nicolaus, on December 6, 1847, in Himmelburg.

When the Tenggs arrived in San Antonio, they purchased the back third of Lot 7 on Block 166 within the study area (Table 6-1). Since the purchase included "a dwelling house and other improvements" (BCDR $\mathrm{K} 2: 497$ ), this was probably their first home. Unfortunately the first two years the family lived in San Antonio are not well documented. They probably immersed themselves in the thriving and growing German community, hoping to find a suitable niche they could occupy.

In 1854 Thomas purchased a small lot on the corner of Third and Elm streets (Giraud, BCA). The property was located to the east of the acequia madre, a few blocks from NCB 166. Also in 1854, Thomas cut whatever ties he may have had to Austria when he declared for naturalization on October 19 (Index to Naturalization Records, County Commissioners' Records, Bexar County Archives).
In the same year, Julius Berends, a Prussian from Brandenburg, opened a bookstore at 237 Commerce Street. Berends, upon his discharge from the Prussian army, fled his homeland and journeyed to Texas. The large German-speaking community and the comparatively liberal political climate probably influenced him to relocate in San Antonio. One of his "first and best" customers was Thomas Tengg, described by Berends as "quite educated" and having a fondness for reading (Julius Berends Papers, Daughters of the Republic of Texas [DRT] Library).

The Tengg's son, Nicolaus, best remembered as Nic, was one of the first students to attend the original German-English School in a rented building on the north side of Commerce Street (Steinfeldt 1978:96). He attended classes in 1858 and 1859, with Julius Berends serving as principal (James 1938:97). Probably as a result of this relationship, young Nic began to work in Berends's bookstore. While at school, Nic's lessons were taught in German and English in an attempt to maintain a cultural contact with Europe while encouraging the students to become more proficient in the language of their new homeland.

On August 27, 1866, at St. Joseph's Church on Commerce Street and with Julius Berends as witness, 18year-old Nic married Louisa Plumeyer, a 22-year-old Prussian-Texan from Rhoden, Prussia, whose family had settled in Comal County. Perhaps in anticipation of the marriage, Thomas Tengg had acquired the front two-thirds of Lot 7 in November of the previous year (BCDR U1:94). A new house was probably under construction in 1867 when, on February 15, Louisa gave birth to a son, named Julius in honor of Julius Berends. Julius, the eldest of the nine Tengg children, was born at the homestead at Third and Elm, an area that was later known as Irish Flats. 
Table 6-1. Property Ownership of Lot 7

\begin{tabular}{|c|c|c|c|}
\hline Area & New Owner & Date & $\begin{array}{c}\text { Source } \\
\text { (B CDR) }\end{array}$ \\
\hline 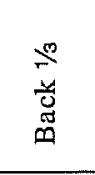 & $\begin{array}{l}\text { Conrad Boechner } \\
\text { George and Katherine Stark } \\
\text { Thomas and Eva Tengg }\end{array}$ & $\begin{array}{l}\text { May } 18,1852 \\
\text { November } 7,1852\end{array}$ & $\begin{array}{l}\mathrm{K} 1: 675 \\
\mathrm{~K} 2: 497\end{array}$ \\
\hline 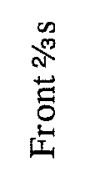 & $\begin{array}{l}\text { Augustine Morset } \\
\text { Thomas and Eva Tengg } \\
\text { Nicolaus Tengg }\end{array}$ & $\begin{array}{l}\text { November } 26,1865 \\
\text { November } 18,1867\end{array}$ & $\begin{array}{l}\mathrm{U} 1: 94 \\
\mathrm{U} 1: 316\end{array}$ \\
\hline
\end{tabular}

In 1867 the senior Tenggs sold Lot 7 to their son (BCDR U1:316). Sometime between 1867 and 1870 the Nic Tenggs moved from the homestead to 326 East Crockett Street. Their second child, Anna, born in 1870, was the first of eight children born at the Crockett Street home (Hindes 1984a).

During this period, Nic remained in the employ of Berends. In 1874 Berends sold the bookstore to Tengg and returned to Europe to live the remainder of his life. The bookstore was rename Nic Tengg's Bookstore. Despite the fact that it moved a number of times, the bookstore was in constant operation by members of the Tengg family.

Tengg offered his customers a wide assortment of books including the classics, various magazines, German-language newspapers, seasonal greeting cards, and gifts. In addition, the bookstore was rapidly becoming an integral part of San Antonio's developing intellectual awareness. In January 1878, Tengg rented a room to the San Antonio Literary Society to be used as a "public reading room."

While business grew, so did the Tengg family. The years from 1872 to 1888 saw the arrival of seven more children. Of the children, Julius made the most significant contribution to San Antonio due to his long association with the family business. He was educated at the German-English School on South Alamo Street, attending from 1874 through 1881 . He is remembered as a kind, soft-spoken person with no shortage of good friends.

Julius was 12 when he began working for his father, and he made it a lifelong commitment. Along with his two brothers, Tom and Edward, Julius and his sister Mary operated the family business. After Nic's death in 1927, Julius, Tom, and Mary remained with the bookstore (Hindes 1984a).

Throughout the years, Nic Tengg, Inc., continued to service the needs of the downtown community. Gradually, however, as San Antonio expanded, an increasing number of merchants abandoned downtown in favor of other locations. The Tenggs chose to remain on West Commerce Street and saw their business begin to decline. Even as the city celebrated the centennial of the Berends/Tengg enterprise in 1954, it was clear the business was failing (Hindes 1984a). With the continual decrease in business, the inevitable occurred in 1961 when the store closed its doors forever.

The family home at 326 Crockett Street was occupied by members of the family until the property was sold to Joske's in 1953. The house and outbuildings were razed to add to Joske's parking lot.

\section{Description of the Property}

The location and type of construction of the original house on the back third of the lot is not known. It may have been taken down when the new stone house was built at the front of the lot. This house (Figure 6-1 ), built ca. 1867 for Nic Tengg, was a one-story "adobe" of soft stone structure with a standing seam metal roof and a porch across the front. The floor was raised ca. four feet above the surrounding ground surface. At some point between 1880 and the turn of the century, a second story was added (Figure 6-2). 

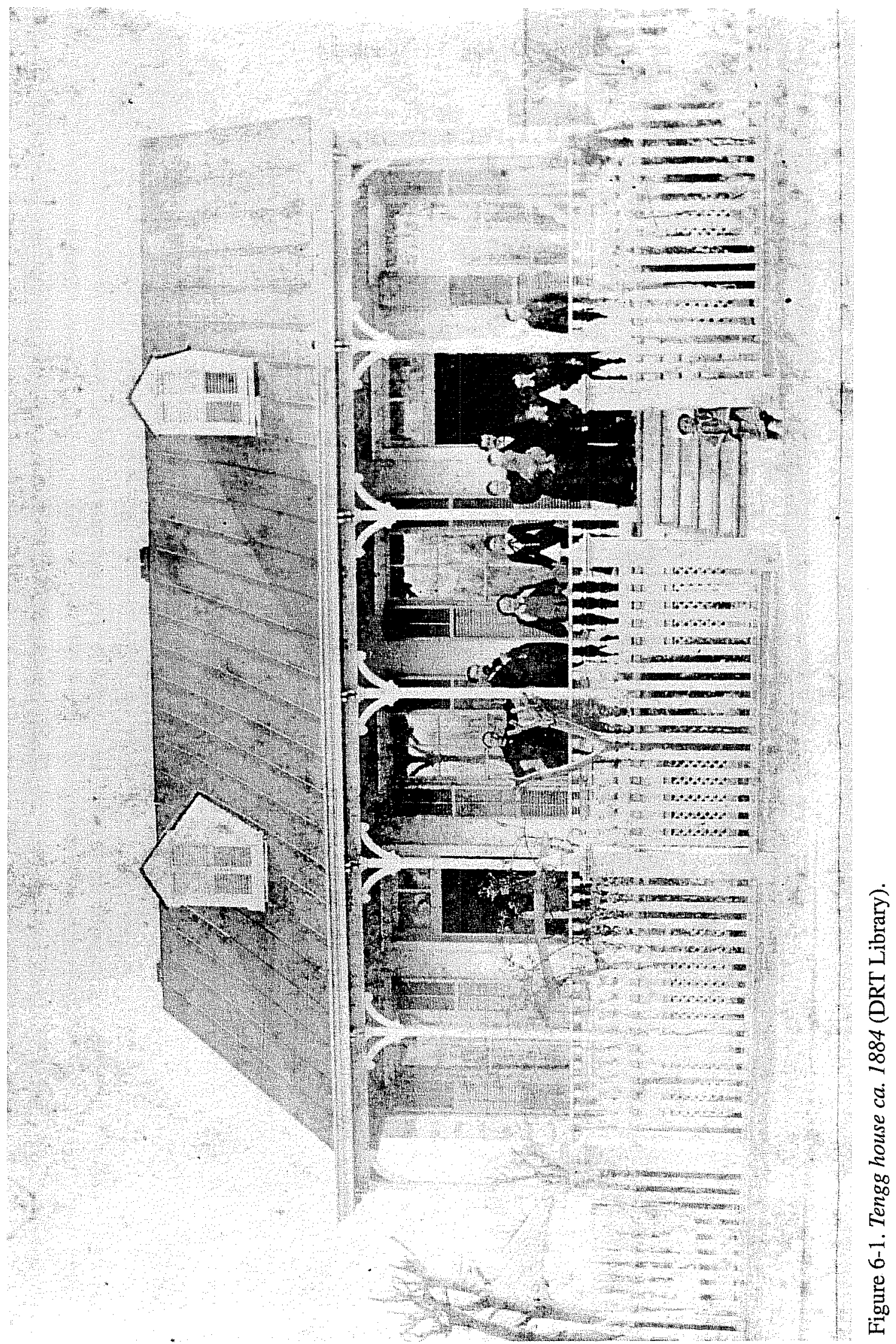


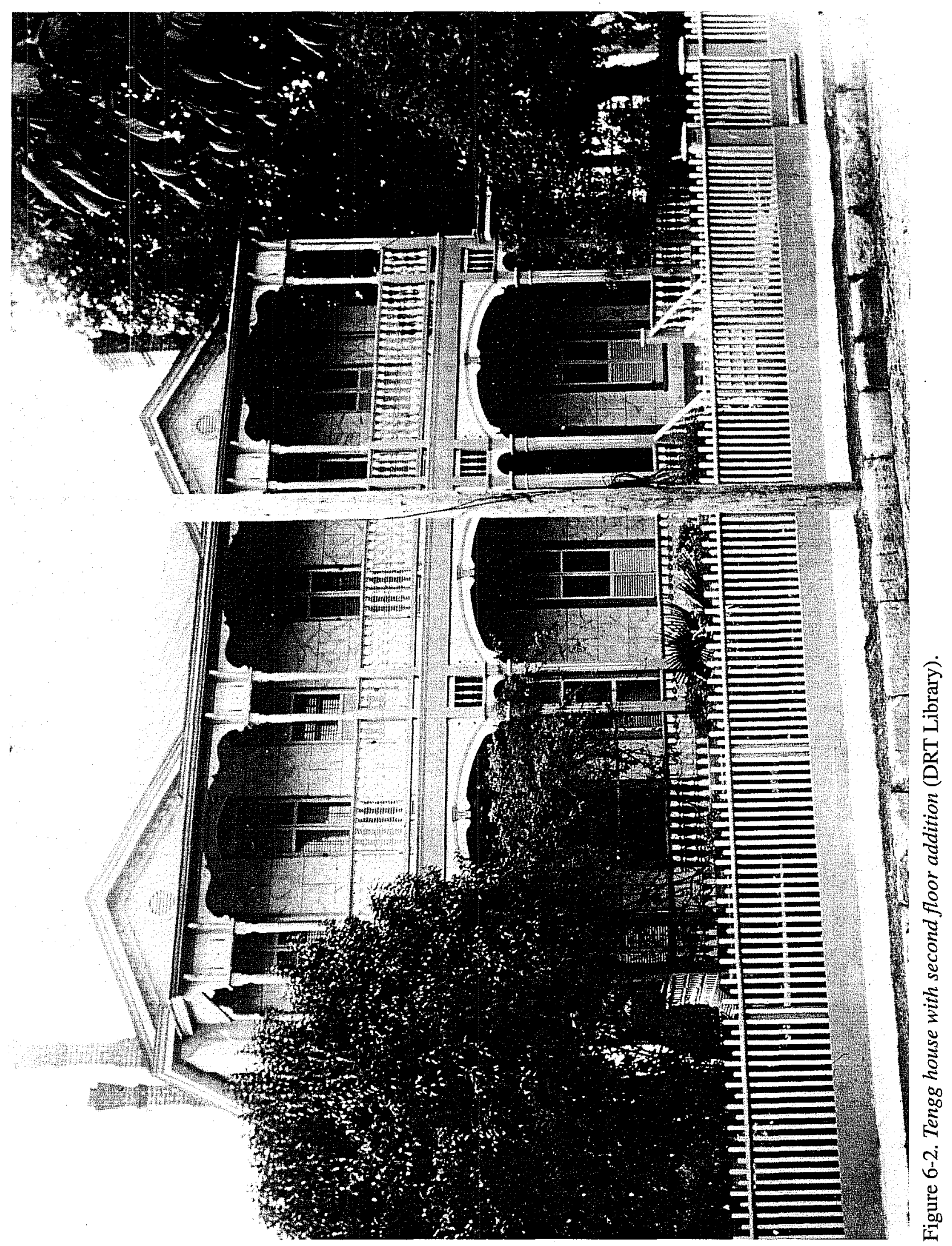


A one-story wing of wood construction was also added to the back of the house in the 1880 s to accommodate the growing family. Porches across the front and back and along the length of the rear addition tie the building together visually and structurally.

Behind the house along the west lot line at the southwest corner, a row of auxiliary buildings was constructed by 1904 . Directly east of these buildings was an octagonal cistern, later concreted over. To the east of this was a two-story carriage house or stable, with had storage and living quarters on the second floor. It is not known exactly when these structures were built, but all were present by the 1904 Sanborn map. The first story of the carriage house was of stone, and was probably built when the house was built in the late 1860 s of soon after. The second story, of brick, may have been added when the house was similarly enlarged in the late nineteenth century.

\section{Archaeological Investigations}

\section{Testing}

A series of backhoe trenches was excavated to delineate the house and outbuilding foundations (Figure 6-3). These were subsequently cleaned by hand. Drawings were then made of the uncovered foundations and details of the construction of individual features.

The stone used in the main house foundation is hard, chisel-cut limestone in medium- to large-size blocks that are generally square. The stones bear quarry drill marks. The mortar is made with sand and lime. The front section of the east and west foundation walls had a footing ledge (Figure 6-4). This feature is absent on the back part of the structure. Examination of the stones and joints near the center of the east wall suggest that the front section may have been built first and the back portion added later. The presence of a few fire bricks along the east wall probably indicates the approximate location of one of the chimnies visible in Figure 6-2. A piece of hardwood flooring observed during testing was labeled "FREM... LUMBER CO. LAREDO."
There were two successive one-story additions to the rear of the house. Apparently access to the basement stairs dictated that the west wall of the rear addition jogged to the west, as indicated on the Sanborn Map of 1904 and in Trenches 2 and 3 (Figure 6-4). The foundation for the later one-story frame addition on the rear is six inches narrower than that for the stone front section, as might be expected. The original back door that led to the basement steps was utilized for access to the new addition. A wooden platform constructed with square-cut nails found at a higher elevation over the landing in Trench B suggests that the stairwell may have been closed off at some point in time.

Finely cut limestone blocks plastered over with cement were used for the basement stairway. The doorway

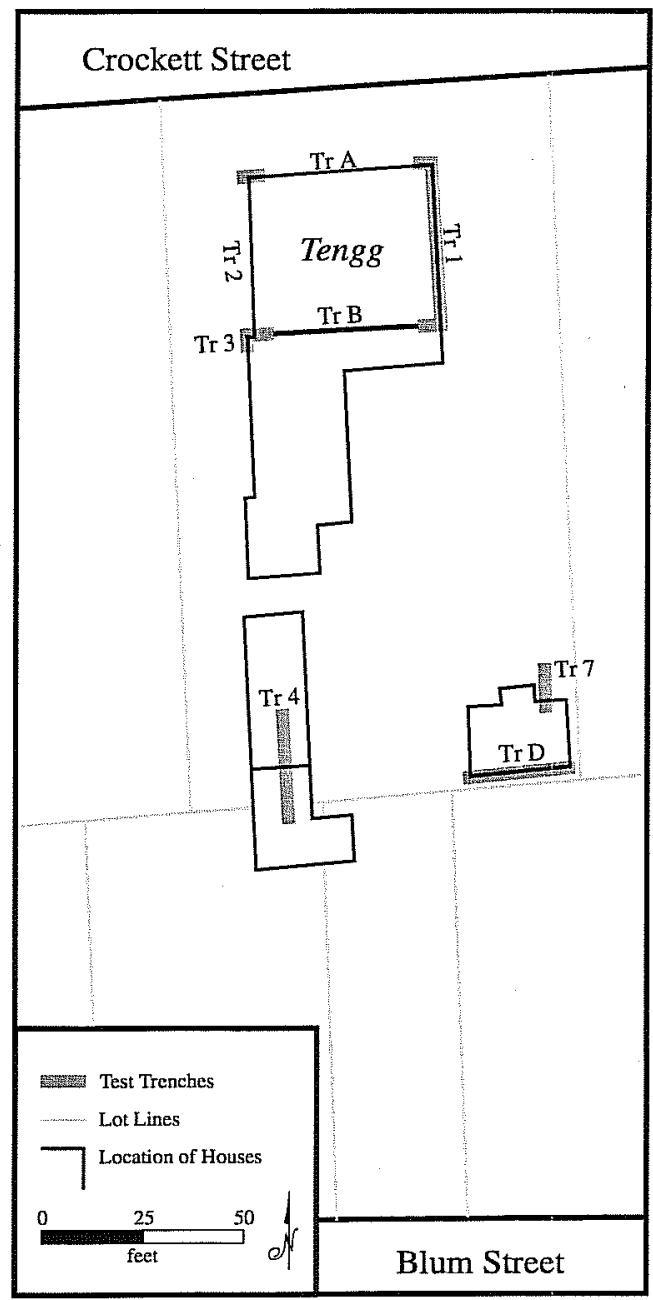

Figure 6-3. Backhoe trenches on Tengg site. 


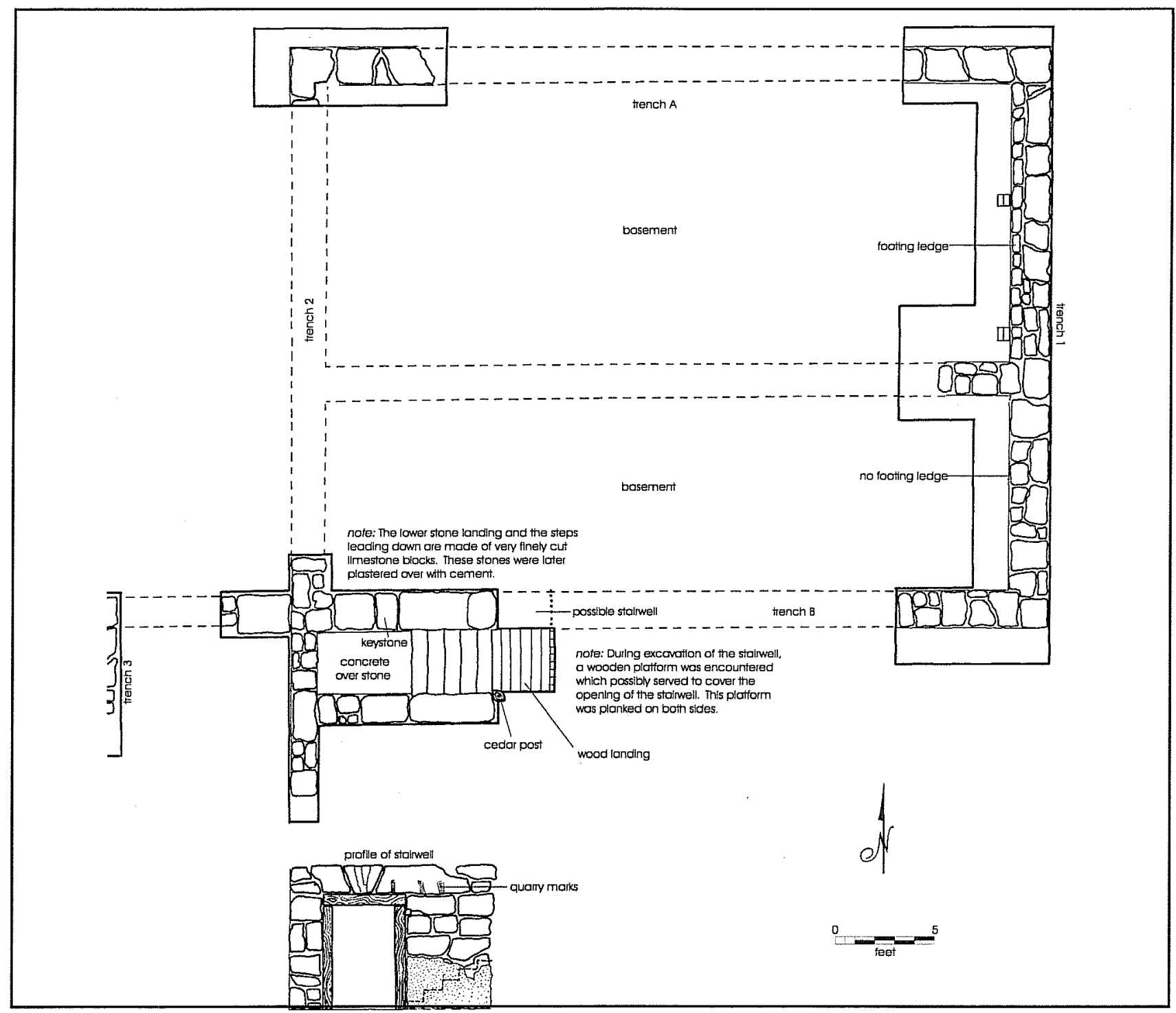

Figure 6-4. Portions of Tengg house exposed in trenches.

into the basement at the bottom of the stairs was constructed with a flat keystone arch. A trench across the side yard to the east of the house revealed that considerable filling had occurred in the vicinity of the house since the construction of the first stone structure.

A test trench (Trench 4) across the outbuildings on the southwest corner of the lot uncovered a trash pit (Figure 6-5) which would have been beneath the building. Artifacts from the pit-including fragments of porcelain electrical fixtures, brick rubble, undecorated ironstone, turn-of-the-century bottle fragments, and a horseshoesuggest a date of late- nineteenth to early twentieth century.
This indicates that the outbuilding in this area was built not long before the 1904 Sanborn map was drawn.

Directly to the east of the trash pit, in the side of the trench, the brick wall of a privy pit was discovered. The trench was widened to the east enough to determine that the top of the pit was filled with loosely packed brick rubble. At four feet of depth in the trench, the brick walls continued downward. The site was recorded, backfilled, and marked for further investigation in the mitigation phase. 


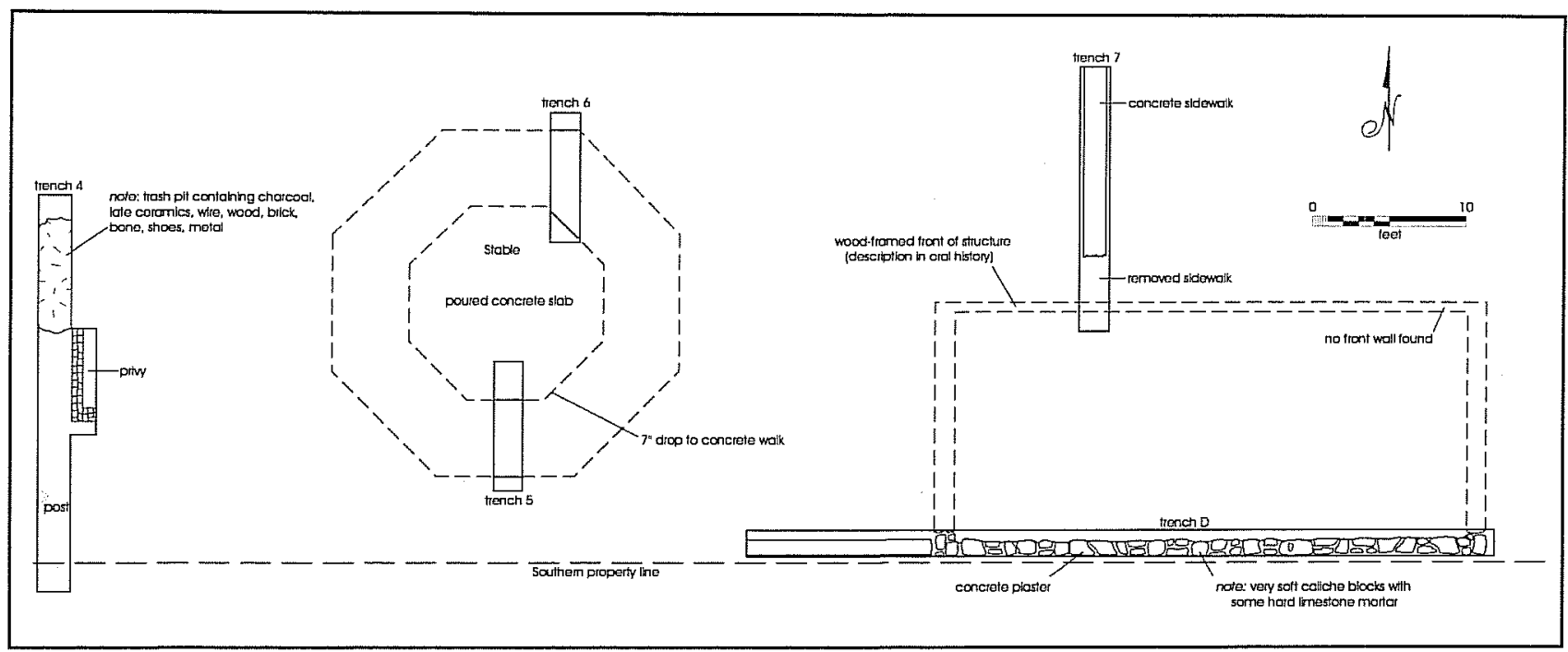

Figure 6-5. Excavations at the back of the Tengg lot.

The concrete cover for the cistern was found to be completely cemented over. Local tradition that it was later used for a storehouse, plus the weight and strength of the concrete, dissuaded the crew from further investigation that would have required bringing in heavy equipment.

Two trenches excavated across the location of the stable revealed concrete sidewalks leading up to the structure, and a stone footing across the back. No trace was found of the front wall of the building, which was probably of wood frame construction. This type of design for stables was popular in late-nineteenthcentury San Antonio (see Schuetz 1970:16 and Figure 2). Artifacts found during testing at the stable indicate quite a bit of modernization must have taken place over the years. There were numerous fragments of porcelain plumbing fixtures, electrical fixtures, and electric insulators. Also present were window glass fragments and cut nails.

\section{Privy Mitigation}

When the crew returned to the privy site and cleared off the asphalt, they found that the privy had once been covered by several large slabs of limestone that sat directly on the brick walls lining the pit. Several of the stones had become dislodged and had fallen onto the top of the pit fill. All of these limestone blocks and the first several feet of brick rubble were removed by backhoe. There was considerable fire reddening of the brick and limestone.

The backhoe was used to dig a deep trench down to the caliche outside the west wall of the privy in preparation for removing that wall to expedite excavation and make a safe work area for the archaeologists. The remainder of the top layer of brick rubble fill was then removed and excavation of the south half of the content of the privy was begun. When we discovered that the upper portion of the fill consisted mainly of gravel, demolition debris such as charred wood, brick, electrical insulators, and firemelted bottles, we decided to collect only diagnostic artifacts and to shovel out this fill without screening. Near the bottom of the pit (Level 5) datable household material in fine-grained deposits appeared. Sterile caliche was reached at ca. $9 \mathrm{ft}$ below the top of the pit walls. The inside of the pit measured 4-x-4 ft.

\section{Artifacts}

Objects recovered during testing around the house were primarily sherds of white ironstone and earthenware and glass bottles dating to the latenineteenth century. Construction material included both cut and wire nails, fragments of electrical wire and fixtures, and a number of sash weights from double hung windows. Similar items came from the backyard in the vicinity of the outbuildings. In addition, that 
area yielded tool and machinery parts, fragments of a license plate, and 13 porcelain insulators.

Excavation of the privy pit produced nothing that can be directly related to individual members of the Tengg household. The upper four layers contained demolition debris, burned glass from various types of containers, $399 \mathrm{~g}$ of animal bone, some shoe parts, cut and wire nails, and tin can scrap (Table 6-2). It would appear that the cavity was filled fairly quickly when the outbuildings were demolished, with a combination of debris from the buildings and trash that had accumulated in the general area. The burned area at the top of the brick foundation walls also indicates the the pit was used for burning after it had essentially been filled. It may be that prior to that time, some sort of incinerator was used nearby and the debris left from the burning was shoveled into the privy pit to cover the contents.

A green Coca-Cola bottle with "SAN ANTONIO, TEXs" on the base, found in Level 5, dates that deposit to after 1903 when the first Coca-Cola bottling plant was established in town (Woolford 1963:162). Fragments of plumbing fixtures and 182 wire nails in this layer are somewhat later than some of the materials in the upper layers of fill. One explanation could be that the upper layers represent demolition of older buildings, while the bottom two layers are contemporary with the last years of occupation of the site. If this is true, an interesting sidelight is the presence in Layer 5 of nine whole clear glass bottles, two of which are flavoring bottles and seven are whiskey or wine flasks. A blue Bromo Seltzer bottle seems a fitting companion to the latter.

The evidence of burning is not present in this layer and the one below, suggesting that these deposits represent use of the pit for its original purpose. This would also explain the recovery of so many whole bottles despite a drop of over seven feet from the ground surface. Layer 5 contained remarkably little household trash, perhaps because modern plumbing in the house made the use of the privy unnecessary except for servants or renters who lived in the carriage house.

In Level 6, the bottom layer, much the same accumulation of artifacts was found. The bottle assortment was similar in that it included nine whiskey flasks. A screw-top salad dressing bottle was also recovered. In this level, as in the one above, the majority of the glass was clear and the bottles bore an Owens ring, indicating they post-date 1903 (Kendrick 1971:83).

Table 6-2. Artifacts from Tengg Site

\begin{tabular}{|c|c|c|c|c|c|c|c|c|c|c|c|c|c|}
\hline Provenience & 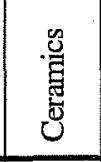 & 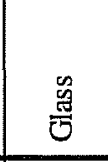 & 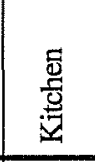 & 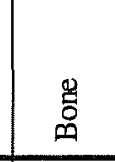 & $\begin{array}{l}\text { 兽 } \\
\text { 空 }\end{array}$ & $\begin{array}{l}\text { 号 } \\
\text { 总 } \\
\text { D }\end{array}$ & 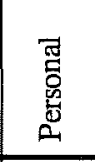 & 蛋 & 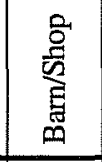 & $\begin{array}{l}\overrightarrow{0} \\
\text { 莺 } \\
\text { 号 }\end{array}$ & 蒡 & Total & \% of Total \\
\hline House testing & 16 & 50 & 3 & 13 & 3 & 0 & 0 & 2 & 0 & 21 & 7 & 115 & $7.36 \%$ \\
\hline Stable & 9 & 9 & 0 & 0 & 0 & 0 & 0 & 0 & 1 & 7 & 4 & 30 & $0.00 \%$ \\
\hline Privy-Surface & 8 & 60 & 25 & 30 & 13 & 3 & 0 & 5 & 4 & 18 & 2 & 168 & $10.76 \%$ \\
\hline Privy-Lv. 1 & 10 & 24 & 25 & 104 & 3 & 11 & 0 & 0 & 27 & 177 & 5 & 386 & $24.71 \%$ \\
\hline Privy-Lv. 2 & 0 & 2 & 24 & 20 & 1 & 0 & 0 & 0 & 23 & 22 & 0 & 92 & $5.89 \%$ \\
\hline Privy-Lv. 3 & 0 & 0 & 0 & 0 & 0 & 0 & 0 & 0 & 0 & 0 & 0 & 0 & $0.00 \%$ \\
\hline Privy-Lv. 4 & 0 & 56 & 22 & 43 & 1 & 0 & 0 & 0 & 6 & 172 & 10 & 310 & $19.85 \%$ \\
\hline Privy-Lv. 5 & 2 & 58 & 4 & 40 & 4 & 0 & 2 & 0 & 5 & 182 & 9 & 306 & $19.59 \%$ \\
\hline Privy-Lv. 6 & 1 & 33 & 23 & 20 & 40 & 3 & 0 & 0 & 6 & 24 & 5 & 155 & $9.92 \%$ \\
\hline Total & 46 & 292 & 126 & 270 & 65 & 17 & 2 & 7 & 72 & 623 & 42 & 1562 & \\
\hline$\%$ of Total & $5.14 \%$ & $18.69 \%$ & $8.07 \%$ & $17.29 \%$ & $4.16 \%$ & $1.09 \%$ & $0.13 \%$ & $0.45 \%$ & $4.61 \%$ & $39.88 \%$ & $2.69 \%$ & & \\
\hline
\end{tabular}


An interesting artifact from this level is a star-shaped molded glass ash tray bearing the stamp "LONE STAR BEER." The Lone Star Brewery was founded in 1884 (Land and Thompson 1885:63). We have no information on when cigarette smoking became popular in San Antonio, but estimate that such commercial advertising would date to the turn of the century or slightly later.

\section{Discussion}

The house built for the young, newly married Nic Tengg in 1867 was a substantial one with a "raised" basement. As the family grew, the house was enlarged to keep pace with their needs, eventually becoming one of the largest and most sophisticated homes in the neighborhood. The construction of a barn/carriage house in the back yard and its eventual enlargement into living quarters for a servant reflected the growing social status of the family as they acquired the bookstore and promoted its growing importance in the town. Always a closely knit family, the children helped out in the store and carried it on for over 30 years after their father's death.The Tengg family continued to live in their house on Crockett Street until 1953. It was the last one to be demolished for Joske's parking lot. 


\section{Chapter 7: The Mueller Site}

Site Identification: NCB 166, Lot 95

Address: 249 Blum Street

Trinomial: 41BX637

\section{Historical Background}

Lot 95 was purchased by J. Charles Mueller from Gustavus Friesleben in 1859 (BCDR S1:143). It had previously been purchased from Charles Riotte by Charles Rossy on March 17, 1857, and then conveyed to Friesleben in 1859 (BCDR P1:182). The low selling prices, $\$ 175$ and $\$ 210$, indicate that no improvements had been made. Mueller, a stone mason, probably began construction of his home (Figure 7-1) in 1859 (City Directory [CD] 1879-1880).

Mueller was born in Germany in 1819 , and arrived in San Antonio in 1851, as attested by his friend and neighbor, Charles Degen (Probate Minutes [PM], Bexar County Courthouse, San Antonio, Texas, J:320). $\mathrm{He}$ and his wife, Maude, resided together at 249 Blum Street until her death in 1879 (CD 1879-1880). On October 6 of the following year, he married the widow Rilling (Marriage Records [MR], Bexar County Courthouse, San Antonio, Texas, G:174).

Anna Maria Rilling, nee Weihing, was born in Wittenberg, Germany, in 1834 and married Jacob Rilling in San Antonio on March 1, 1855 (U.S. Census 1860; MR C:265). Rilling was also from Wittenberg and was born in 1831 (U.S. Census 1860). They had six children (PM J:339) and lived on North Street, between Second and Third streets, until Jacob's death prior to 1879 (CD 1877-1878, 1879-1880).

After her marriage to Charles Mueller, Anna moved to the Blum Street address (PM, J:320). There were no children of this union, and at the time of his death in February 1884, Mueller's assets were listed as the house and lot, valued at $\$ 2,200$, and $\$ 50$ worth of household furniture and effects (PM, J:339). The widow Mueller continued to reside on Blum Street. Sometime between 1897 and 1903, the structure at 249 Blum was constructed, apparently as rental property (CD 1897-1898, 1903-1904).

Anne Maria died at the age of 70 on September 22, 1904, never having become an American citizen. The cause of death was "apoplexy" (a stroke) according to the attending physician, Dr. C. M. Decker (Death Records 1:1518). Her obituary stated she was "greatly loved and admired by the German citizens" (San Antonio Daily Express [SADE], 23 September 1904). Surviving her were her children by her first marriage, Jacob and George Rilling, Mrs. Paul Joshing, Mrs. Paul Pretzer, Mrs. John Loesberg, and Mrs. Charles Steffler, and 32 grandchildren (SADE, 23 September 1904).

Sometime soon after 1897, another house had been built on the east side of the property (Figure 5-2). Both houses continued in use as rental properties until they were razed in 1936. There was a long succession of tenants, with a complete changeover nearly every year, according to the City Directories. The original plan was to test Lot 12 on the northeast corner of this block, but Lot 95 was substituted at the request of Allied Stores so as not to interrupt a parking lease on the former. This property was chosen for testing because of its German ownership and its apparent succession of lower-middle-class tenants and the fact that the acequia lateral was thought to have formed the back lot line. 


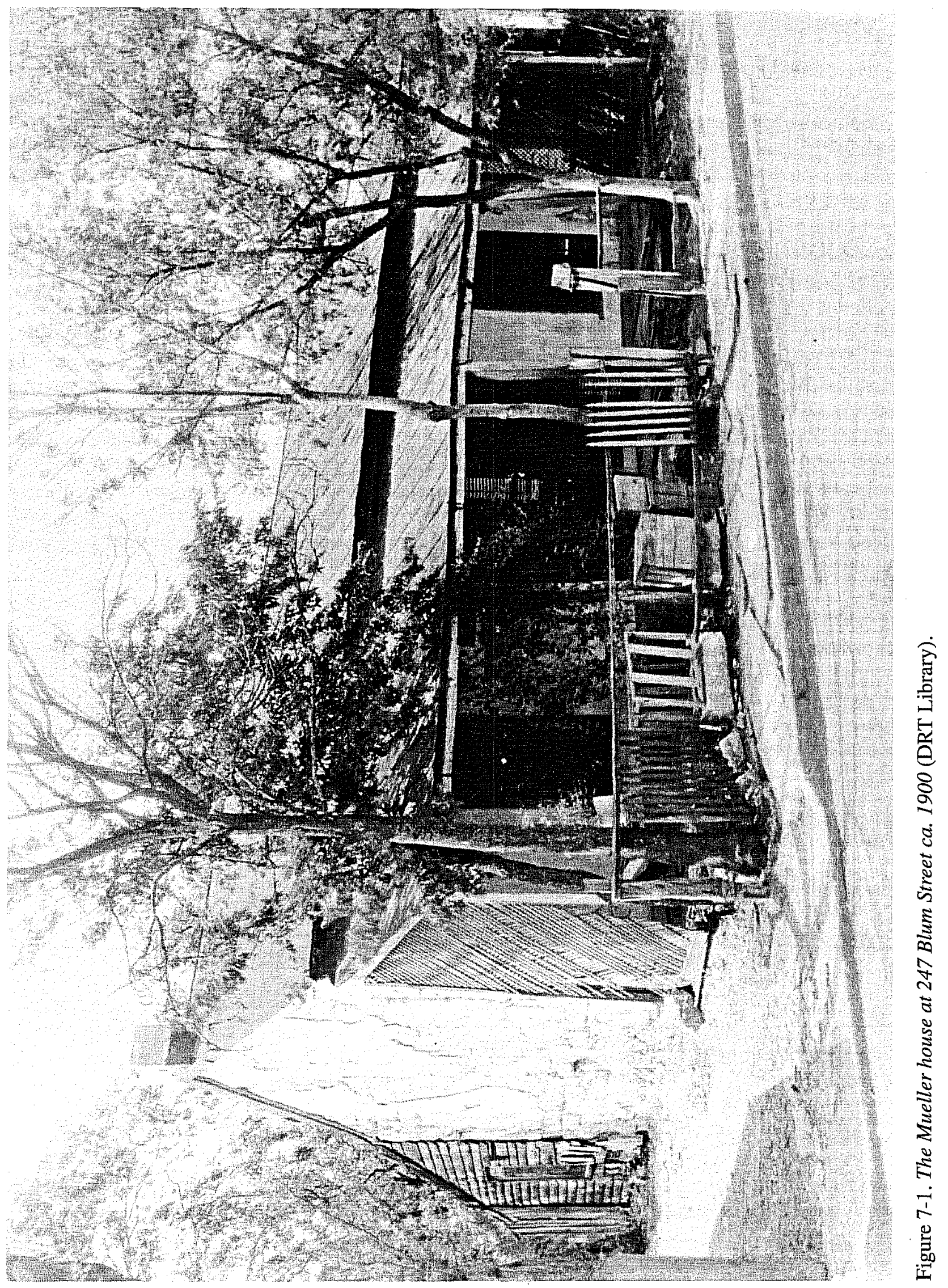




\section{Archaeological Investigations}

\section{Test Excavations}

The first test trench was excavated perpendicular to the back lot line near the northwest corner. This trench extended across the center line of the acequia lateral indicated on the early ownership maps, apparently dictating the back line of all lots on this block. The trench encountered a segment of stone wall running north-south across the lot line. In the immediate vicinity of this wall we found a deposit of latenineteenth-century artifacts which, at the time, we thought was fill within the lateral, deposited after it went out of use (see Hindes 1984a). Later mitigative excavations in this area revealed that the stone wall was part of the lining of the Mueller family privy, and the artifacts were part of the privy fill. Additional trenching across the line of the acequia lateral to the east revealed that it had been entirely eliminated by land alterations, perhaps at the time of the division of the block into individual lots.

One long test trench was excavated by backhoe across the entire lot from west to east across the line of the front walls of the houses, to locate and examine the foundations of both houses (Figure 7-2). Since the 1904 Sanborn Insurance map showed no substantial structures elsewhere on the lot, no further testing was done. Other than a few fragments of bottle and window glass, no artifacts were found during this testing, evidence that the original ground surface had probably been removed when the houses were demolished and the area paved for parking. Beneath two inches of asphalt and 8.5 inches of clean gravel fill, the tops of the east and west wall foundations for the adobe house were found. They were roughly 20 inches wide and consisted of small limestone blocks set in adobe mortar. The house measured approximately $40 \mathrm{ft}$ across the front.

About $18 \mathrm{ft}$ to the east, a large limestone block indicated the location of the later rent house. Two similar blocks at approximately $10-\mathrm{ft}$ intervals represented the foundations of this house. In this case, the foundations appeared to be formed of large, solid limestone blocks, interspersed with smaller pieces of softer limestone. Next to the easternmost foundation stone, just outside the wall, was set a cedar post. Cedar posts were found in similar locations at other "adobe" houses during these test excavations. They appear to be related to the construction of the front porch, which traditionally was appended to the front wall of the house.

\section{Excavation of the Privy}

The privy, which had a maximum length of 87 inches and a maximum width of 45 inches (Figure 7-3), was excavated by arbitrary and stratigraphic levels to a maximum depth of 83 inches beneath the existing ground surface. Large limestone chunks and limestone rubble were used to construct the privy. Three soil

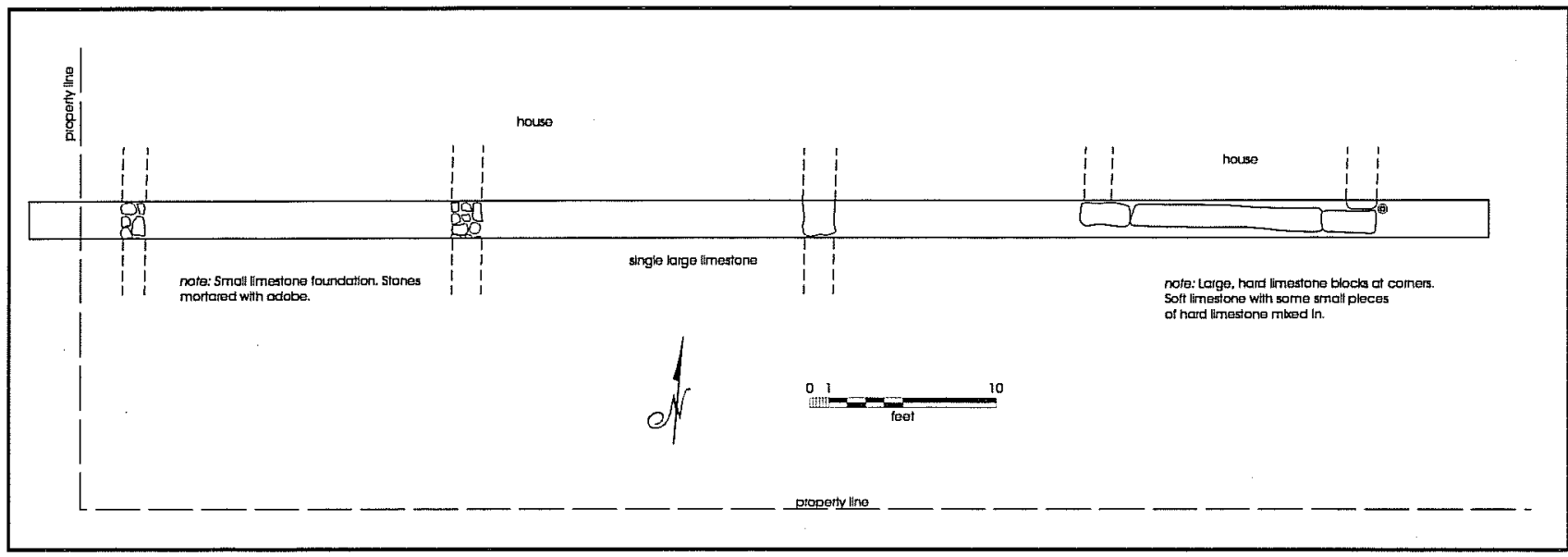

Figure 7-2. Test excavations at the Mueller house site. 


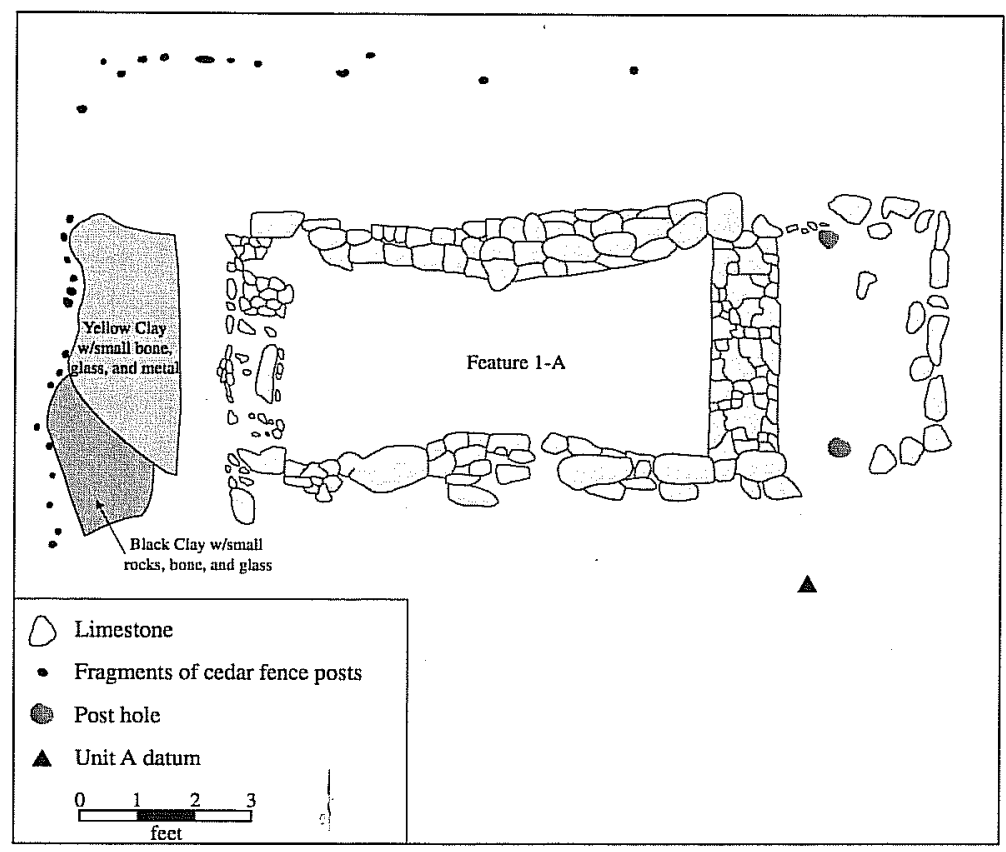

Figure 7-3. Plan map of the Mueller privy.

changes were observed: a dark gray clay was observed from 15 inches (a concrete parking lot had covered the original surface) to 41 inches beneath the surface; a loose, moist brown sandy-clay was recorded between 41 and 46 inches; and mottled reddish-brown and gray clays were identified between 46 and 83 inches. Arbitrary levels were utilized to maximize control over vertical provenience as some of the soil layers were quite thick. Five excavation levels, excluding a preparatory surface cleaning level, were used. The following artifact analysis has considered the deposits as a single spatial-temporal unit since both halves of the privy were excavated following the same levels. Moreover, the entire privy is hereafter referred to only as Feature I-A for clarity.

\section{Artifacts}

\section{Ceramics}

A total of 10,693 artifacts were recovered from Feature I-A (Table 7-1).Three hundred forty-four ceramic sherds were recovered from the privy. The ceramic assemblage represented 3.22 percent of all artifacts. Nineteen vessels-11 tablewares and 8 toilet wares-were either partially or fully reconstructed from 117 sherds.

More than half ( 56.10 percent, $n=193$ ) of the recovered ceramics were undecorated whitewares. Porcelain and semi-porcelain constituted a relatively large portion ( $n=69,20.06$ percent) of the ceramic assemblage. The five unglazed sherds (1.45 percent) and two lead-glazed sherds ( 0.58 percent) appear to be from cooking vessels (bean pots). Nineteen of the 24 stoneware sherds could be identified by type: 17 salt-glazed sherds and two Albany slipped sherds were recovered. The two sherds categorized as "other" were too small to positively identify, but appear to be yellowware.

Table 7-1. Artifacts from the Mueller Privy

\begin{tabular}{|c|c|c|c|c|c|c|c|c|c|c|c|c|c|}
\hline Level & 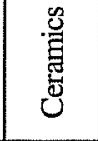 & 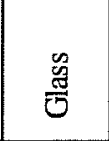 & $\begin{array}{l}\text { 志 } \\
\stackrel{\overrightarrow{3}}{3}\end{array}$ & 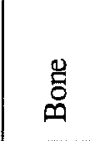 & 喜 & $\begin{array}{l}\stackrel{\infty}{E} \\
\stackrel{ }{0} \\
\frac{0}{0}\end{array}$ & 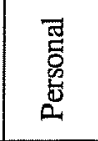 & 旁 & 壹 & 告 & 鸹 & Total & $\begin{array}{l}\% \text { of } \\
\text { Total }\end{array}$ \\
\hline 1 & 117 & 528 & 5 & 648 & 56 & 31 & 7 & 30 & 31 & 0 & 740 & 2193 & $20.51 \%$ \\
\hline 2 & 21 & 37 & 3 & 163 & 11 & 3 & 1 & 4 & 66 & 0 & 70 & 379 & $3.54 \%$ \\
\hline 3 & 72 & 356 & 22 & 488 & 339 & 29 & 14 & 31 & 30 & 21 & 376 & 1778 & $16.63 \%$ \\
\hline 4 & 80 & 346 & 4 & 1126 & 414 & 20 & 14 & 11 & 15 & 27 & 257 & 2314 & $21.64 \%$ \\
\hline 5 & 54 & 1429 & 0 & 1952 & 202 & 34 & 2 & 4 & 5 & 34 & 313 & 4029 & $37.68 \%$ \\
\hline Total & 344 & 2696 & 34 & 4377 & 1022 & 117 & 38 & 80 & 147 & 82 & 1756 & 10693 & \\
\hline $\begin{array}{l}\% \text { of } \\
\text { Total }\end{array}$ & $3.22 \%$ & $25.21 \%$ & $0.32 \%$ & $40.93 \%$ & $9.56 \%$ & $1.09 \%$ & $0.36 \%$ & $0.75 \%$ & $1.37 \%$ & $0.77 \%$ & $16.42 \%$ & & $100.00 \%$ \\
\hline
\end{tabular}


A great deal of typological variability was observed among the 40 (11.63 percent) decorated wares. Fourteen edge-decorated ware ( 12 blue and two green) sherds were recovered from Level 1 . Red transferprinted sherds were recovered from Levels $1(n=6)$ and $4(n=3)$. The sherds from Level 1 had an unidentified geometric pattern and the sherds from Level 4 contained unidentified floral patterns. A plate from Level 4 with a raised alphabet (letters $R$ through V) and also had a geometric red transfer print on the edges. Thirteen unmendable sherds of a handpainted band and line (executed in brown, yellow, and blue) bowl were recovered from Level 1. Another red and blue handpainted band and line sherd was excavated from Level 4. Finally, two sherds from a saucer with a handpainted polychromatic floral design were recovered from Level 1.

Nineteen vessels were reconstructed using mended and crossmended sherds from the privy. The vessels included five teacups, one small plate (Figures 7-4 and 7-5), two large plates, two saucers, one oval dish, one chamber pot, and seven bath sets (Figure 7-6).

Figure 7-4. Porcelain cup from the Mueller privy.

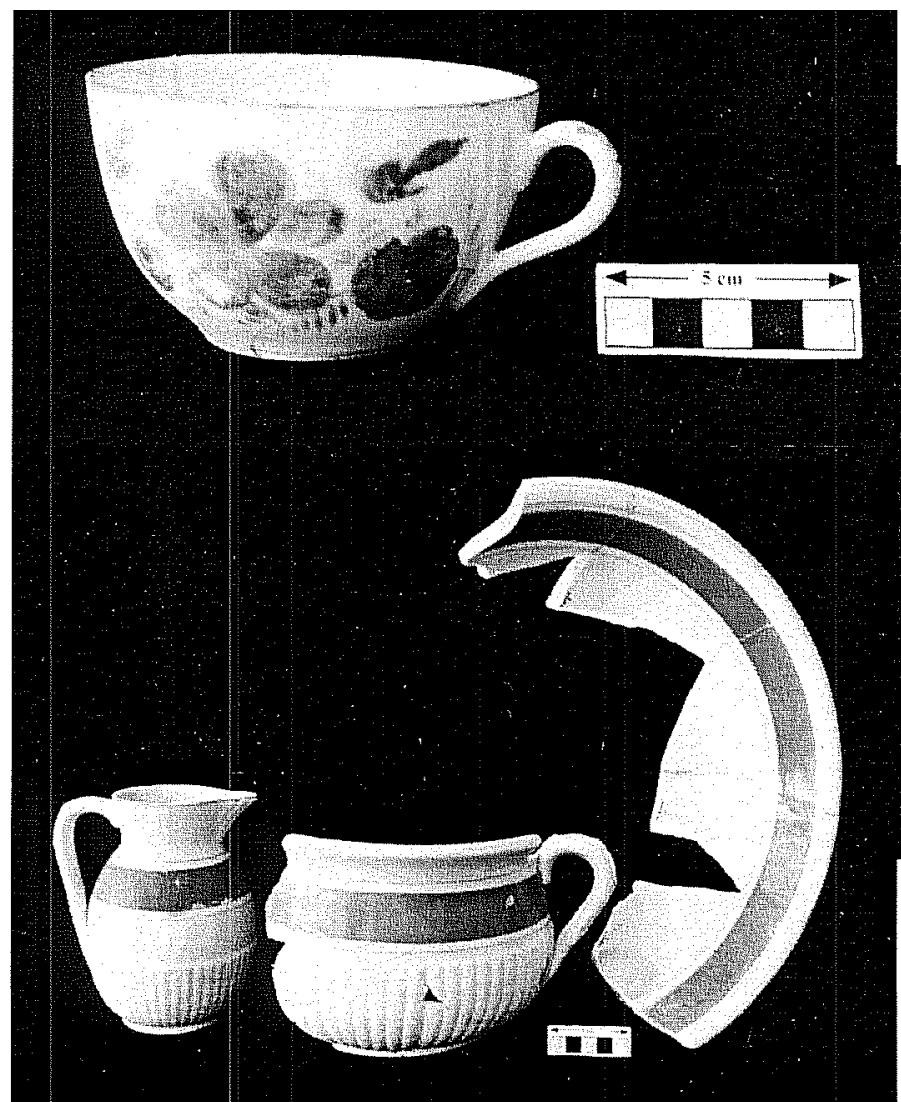

The crossmended sherds suggest that Levels 3, 4, and 5 are a temporally contemporaneous deposit. Seven vessels were partially reconstructed from sherds from Levels 4 and 5; four vessels were reconstructed from sherds from Levels 3 and 4; and two vessels were reconstructed from sherds from Levels 3,4 , and 5 . No sherds from the upper two levels could be crossmended with sherds from lower levels. One vessel from Level 1 was reconstructed from three sherds. One vessel was reconstructed from 10 mended sherds from Level 3. Two vessels were also reconstructed with mended sherds in each of Levels 4 and 5.

Only three makers' marks could be identified. A "ROYAL IRONSTONE CHINA/CLEMENTSON

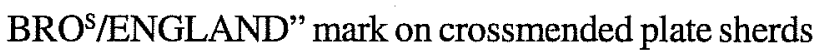
recovered from Levels 4 and 5 was manufactured between 1867 and 1880 (Godden 1964:149). An "IRONSTONE CHINA/J.\&G. MEAKIN/HANLEY/ ENGLAND" mark, also on crossmended (Levels 4 and 5) plate sherds, was produced in ca. 1890 (Godden1964:427). The final partial mark, "HAVIL...FR...," found in Level 1, has been identified as Haviland and Co. of Limoges, France, and was

Figure 7-5. Semiporcelain plate from the Mueller privy.

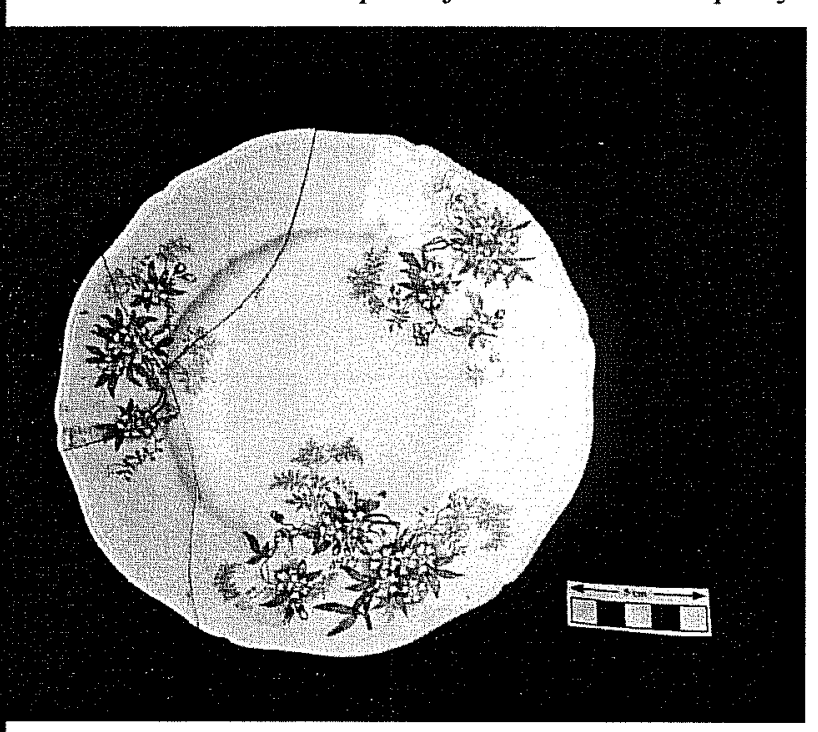

Figure 7-6. Bath set from the Mueller privy. 
used between 1840 and the early twentieth century (Kovel and Kovel 1971; Thorn 1947)

\section{Bottle Glass}

Some 2,696 bottle glass sherds were recovered from the privy. The entire glass assemblage represented 25.21 percent of all artifacts excavated from the privy. The glass assemblage is large relative to other privies excavated in the project area. There were no temporally diagnostic sherds; temporal information was collected from complete and nearly complete bottles. The greatest quantity of glass was observed in Level 5. This assemblage includes an interesting sample of medicine bottles, drinking glasses (Figure 7-7), and tumblers (Figure 7-8).

The total included 82 whole bottles. An analysis of the original contents of the bottles revealed that the overwhelming majority of the bottles $(n=67,81.70$ percent) contained a medicinal product. In addition, four condiment bottles (4.88 percent), four cosmetic/ hygienic bottles (4.88 percent), one chemical (1.22 percent), one ink (1.22 percent), one soda/water (1.22 percent), and one alcohol bottle (1.22 percent) were observed. Also, three bottles (3.66 percent) with unknown contents were recovered.

A mean date for the bottle assemblage was calculated following procedures described by South (1977) and Thomas (1989) (Table 7-2). Fifty-nine of the bottles could be assigned a date of manufacture (or a range of dates). Dates were obtained from bottles $(n=60)$ from 10 pharmacists or drug stores in San Antonio, one soda bottle produced in San Antonio ("Duerler"), four medicinal bottles from other states, two hygienerelated bottles ("Sozodont" and "St. Jakob's Oel"), and from a bottle with unknown contents with a "JWK" maker's mark. Two of the "F. Kalteyer \& Son" bottles, however, had " $\mathrm{M}^{\mathrm{C}} \mathrm{C}$ " maker's marks on their base. Toulouse (1971:351-2) believes that the " $\mathrm{M} C \mathrm{C}$ " mark was used between 1841 and 1886 so we calculated a new, composite median date (1882.5) using 1879 (the earliest date for Kalteyer and Son) and 1886 (the last year the $\mathrm{M}^{\mathrm{C}} \mathrm{C}$ mark was used) for the two bottles. Also, because a few of the local druggists were not in continuous business, we
Table 7-2. Mean Dates of Bottles

from the Mueller Privy.

\begin{tabular}{|l|c|c|c|}
\hline Name(s) & $\mathrm{n}=$ & Date(s) & Median Date \\
\hline Tips \& Silverthorn & 4 & 1891 & 1891 \\
\hline Dowling \& Flood & 2 & $1881-1896$ & 1888.5 \\
\hline A. Nette & 3 & $\begin{array}{c}1877-1888 \\
1881-1891\end{array}$ & 1884 \\
\hline C. Schasse & 3 & $1877-1906$ & 1891.5 \\
\hline Char Campbell & 1 & $1892-1898$ & 1895 \\
\hline F. Kalteyer \& Son & 2 & $\begin{array}{c}1879-1891 \\
1895-1910\end{array}$ & 1894.5 \\
\hline $\begin{array}{l}\text { Alamo Drug Store } \\
\text { A. Driess }\end{array}$ & 36 & $1877-1906$ & 1891.5 \\
\hline JW K & 1 & $1844-1847$ & 1845.5 \\
\hline Kalteyer \& Son (McC) & 2 & $1879-1886$ & 1882.5 \\
\hline Kalteyer \& Schuchard & 3 & $1892-1893$ & 1892.5 \\
\hline W. D. Albini & 2 & $1887-1893$ & 1890 \\
\hline P. G. Lucas & 1 & $\begin{array}{c}1891 \\
1899-1910\end{array}$ & 1900.5 \\
\hline Duerler & 1 & $1885-1910$ & 1895.5 \\
\hline Dr. King's N ew Discovery & 2 & 1898 & 1898 \\
\hline
\end{tabular}

calculated the median date for the entire possible range. The median date was multiplied by the number of particular bottles. Finally, a mean date was calculated for the entire assemblage of median dates. The mean date result for the identifiable marks was 1890 .

\section{Kitchen}

The 34 kitchen artifacts represented 0.32 percent of all artifacts recovered from the privy. Kitchen artifacts were recovered from every level except Level 5. The largest concentration was recorded in Level $3(n=22)$, including 14 knife fragments, 6 spoon fragments, and 2 complete spoons. The remaining kitchen item artifacts included a ladle handle and fragments from a graniteware (cooking) vessel.

\section{Bone}

Animal bone was the most frequently recovered artifact. A total of 4,337 bones was excavated (40.93 percent of all artifacts recovered from the privy). Bone accounted for more than 40 percent of the artifacts recovered from Levels 2,4 , and 5 , and over 25 percent for Levels 1 and 3. The largest faunal deposit was observed in Level $5(\mathrm{n}=1952)$. A more detailed 


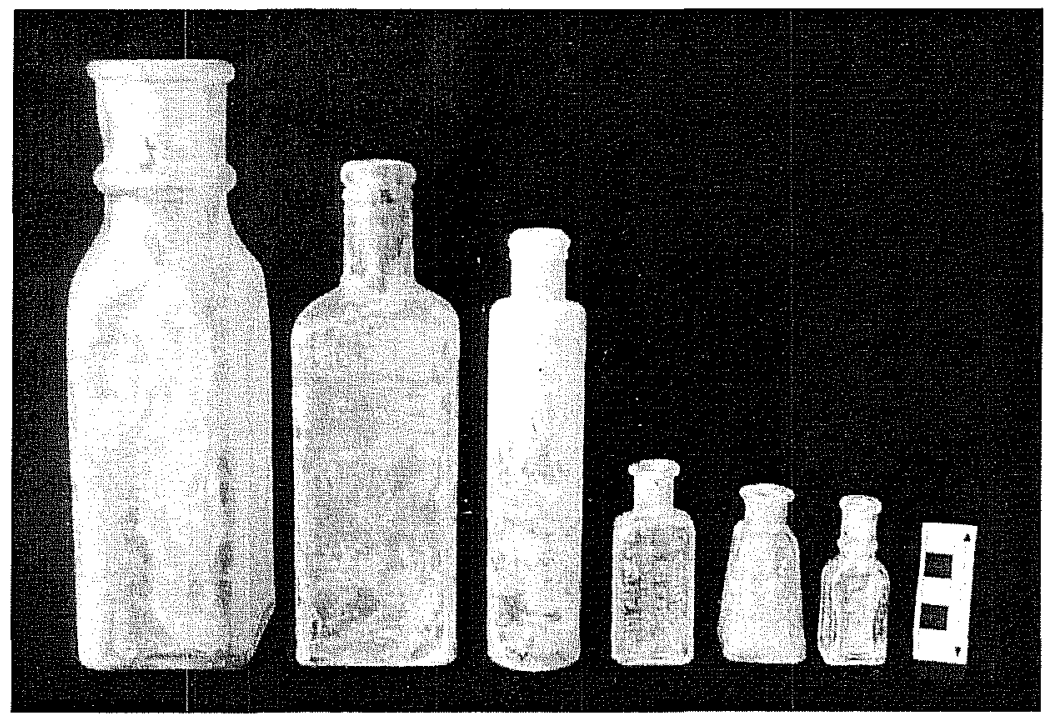

Figure 7-7. Representative bottles from the Mueller privy.

Figure 7-8. Drinking goblets from the Mueller privy.

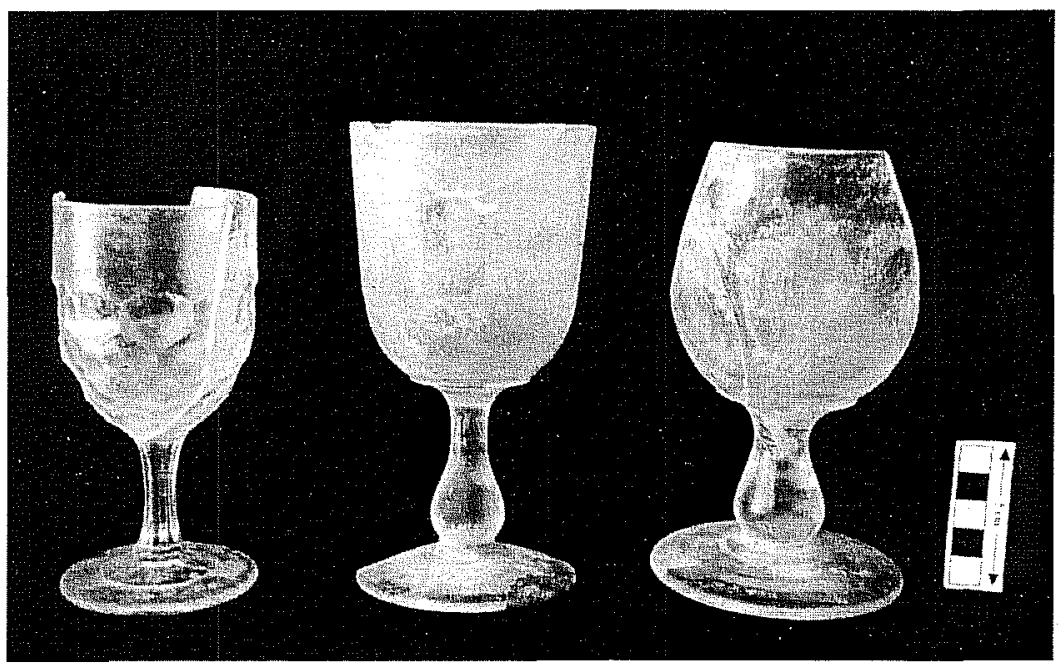

analysis of the faunal materials is given in Appendix A.

McClure (Appendix A) found that a variety of animals-pigeons, deer, pork, chicken, turkey, and beef-were consumed by the residents of 41BX637. McClure believes that beef, especially roasts and steaks, was the dominant meat. There is also evidence that one or more of the residents went hunting and fishing, as fresh and saltwater fish, deer, game birds, and rabbits were identified. Game animals, however, were not a sizable portion of the faunal assemblage and were identified only in Levels 3,4 , and 5. Very few edible cuts could be identified for any of the animals (domestic and wild) indicating that kitchen scraps were deposited elsewhere. McClure (Appendix A) suggests, in fact, that many of the bones from Level 2 had been burned and then deposited into the privy vault. Perhaps, then, the privy was functionally reserved primarily for non-perishable refuse.

McClure (Appendix A) also found the remains of a number of rats in the lower levels. He believes that the rats were killed elsewhere and then deposited into the privy. There was also evidence from Level 5 that the occupants of the site kept cats and dogs: the remains from five sub-adult dogs and 11 kittens were excavated. 


\section{Furniture}

A total of 1,022 household furnishing artifacts $(9.56$ percent of all artifacts recovered from the privy) was identified. A majority ( $n=891,87.18$ percent) of the furnishing assemblage was comprised of chimney glass fragments. Six extremely narrow, cylindrical, clear glass objects were also recovered. The function of these is unknown. Also observed were a kerosene lamp well and various lamp fragments. The remaining furnishing items consisted of light bulb glass and flower pot fragments.

\section{Personal}

Thirty-eight personal artifacts were excavated from the privy (0.36 percent of all recovered artifacts). Select items are described. Decorative items included two glass beads (one orange, one turquoise), a locket, two fragments from a cuff link, and a pin with a purple glass "gemstone."

Hygienic items include three bone toothbrush handles (two were engraved with "The Ladies Perfect Brush/ Loonen/Paris" and one was engraved "La Divina/A. Dupont/Maker"), three ear syringes, three glass hypodermic syringes, two fragments from a douche, and comb.

Tobacco-related items include snuff-can fragments, one intact snuff can, and three pipes. One of the latter was made from wood and bone, and two were ceramic.

Other notable, but ultimately undiagnostic, personal items included four dice (one of which, from Level 5, contained one four, four fives, and one six) and three unidentified/illegible tokens or coins.

\section{Activity}

The 80 recovered activity artifacts represent 0.75 percent of all recovered artifacts. Three-quarters of the activity artifacts were recovered from Levels 1 and 3 ( $n=30$ and $n=31$, respectively). The most frequently identified activity artifact collected was 27 slate (writing board) fragments. Twenty-four doll fragments, several doll dishes, and eight unidentifiable marbles were also excavated.

\section{Arms}

The 83 arms artifacts represented 0.73 percent of all artifacts. Twenty-one rifle cases were recovered from Level 3, 22 cases were excavated from Level 4, and 29 cases and five fragments of a shotgun stock came from Level 5. Smith and Smith (1985) completed an analysis of the recovered projectiles and identified five .56 caliber Minnies. Minnies were introduced in the 1830s and adopted by the U.S. Army in 1855 (Fadala 1979:119 and Matloff 1969:181, in Smith and Smith 1985). Minnies were typically fired by Colt Revolving rifles. Few of the Colts were produced, however, because of mechanical malfunctions ("licking over" or fire escaped the breech and set off all the chambers at once). Smith and Smith suggest that Minnies were not used after about 1870 .

\section{Construction}

Approximately 1,712 construction-related artifacts were recovered from the privy. Construction artifacts represented 16.01 percent of all artifacts recovered from the privy; compared to other privies excavated in the project area, the Mueller privy had relatively few construction artifacts. Construction artifacts were recovered from every level in the privy with the largest concentration in Level $1(\mathrm{n}=740)$ and the fewest in Level $2(n=70)$.

Included in the total is a small amount of architectural debris, including such items as plaster fragments ( $n=46,2.69$ percent of all construction artifacts), mortar fragments $(n=29,1.69$ percent), concrete fragments $(n=43,2.51$ percent), shingles $(n=11,0.64$ percent), bricks and brick rubble ( $n=17,0.99$ percent), and wood ( $n=15,0.88$ percent).

Window glass ( $n=437,25.53$ percent), wire nails ( $\mathrm{n}=844,49.30$ percent), and cut nails $(224,13.08$ percent) accounted for almost 90 percent of the 
construction assemblage. Forty-four (2.57 percent) screws, bolts, and nuts were also collected.

These artifacts represent the period of the 1880 s to the 1890s. They reflect a complete range of household objects-from ceramics to ammunition-in use during that time.

\section{Discussion}

When Mr. Mueller's first wife died and he married the widow Rilling, no one could have predicted that within a few years she would be a widow for the second time. Fortunately she had six grown children from her first marriage to comfort her and look after her affairs. Since Mueller left her only the house and furniture, she may have had a difficult time financially. This could possibly explain why by 1900 another house had been built on the property to use for rental purposes.

Analysis of the contents of the privy against the back fence reveals that Mrs. Mueller may have had health problems in her last years. The dates of the artifacts from the privy indicate that the contents were related to her 1884 to 1904 occupation of the house. They paint a picture of the declining health of a woman of German origin (suggested by the stoneware from her kitchen) who may have brought to her second marriage some of her good porcelain, semiporcelain, and glassware. Apparently she had both dogs and cats as pets, perhaps to help control the rat population which appears to have been a problem in the town during the last part of the nineteenth century (James 1938:94). The snuff cans could have come from either Mr. or Mrs. Mueller. Some San Antonio women dipped snuff in the late nineteenth century, as indicated by the presence of an ornate spittoon recovered from the well on the Vanderstratten property (see Chapter 8). The doll parts and marbles in the privy probably represent visits of grandchildren. After Mrs. Mueller's death, her family apparently continued to manage the rentals of the two houses for a considerable time. Finally in 1936 the houses were razed and the property was cleared.

We have attempted to provide as much raw data as possible in this report since the site contains potentially important information: the artifacts appear to have been deposited when the house was occupied by a woman. Thus the material excavated from 41BX637 could substantially add to understanding and interpretation of gender at historical sites. However, we found it difficullt to isolate gender from socioeconomic status or other factors influencing the use and deposition of certain items. For instance, the large number of medicinal bottles coupled with the absence of alcohol bottles could suggest multiple hypotheses. Perhaps the bottle assemblage reveals that it was more appropriate for a woman to consume alcohol covertly. Or the large quantity of medicine may simply be an indication of age and decreasing health rather than gender. Such ideas could be pursued with further analyses. 


\title{
Chapter 8: The Vanderstratten Site
}

\author{
Site Identification: The Vanderstratten Home, NCB 166, Lot 3 \\ Address: 212-214 Bonham Street
}

Trinomial: 41BX634

\section{Historical Background}

At the corner of Crockett and Bonham streets stood one of the earliest homes constructed within the study area (Figure 8-1). It was built of soft caliche block in 1850 and occupied the site for 75 years. It in many ways it typifies the development, evolution, and degeneration of the area over its lifetime. It remained in the hands of the family for three generations.

The property was purchased from Charles Riotte by Joseph Vanderstratten on November 29, 1850, with money provided by his son, Theodore. Since the son was a stonemason by trade, he probably constructed the home shortly thereafter. The lot, then referred to as Lot No. 3, ran from the south side of Crockett Street with a frontage of 60 varas ( $166.6 \mathrm{ft}$ ) along the eastern line of Bonham Street, to "an irrigation ditch" for the southern boundary. The irrigation ditch would have been a lateral from the Acequia Madre ditch along the eastern portion of the subject area (District Clerk's Office (DCO), 4th Judicial District Court Records, suit before Judge Thomas J. Devine between Theodore and Joseph Vanderstratten, 1856, Bexar County Courthouse, San Antonio, Texas).

Joseph Vanderstratten was born January 1, 1790, at Weynigem, Province of Antwerpen (Antwerp), Belgium. In 1846 Joseph and five of his children-Frank, Theodore, John, Joseph, Jr., and Cordelia — joined the emigration movement of Henri Castro to relocate in Texas. They arrived at Port Lavaca in June, then traveled overland by ox cart to their land in Castroville, but found the land too harsh and settled in San Antonio instead. Joseph had left a wife and one daughter in Belgium until a home could be prepared for them, but before he could provide transport for them his wife contracted a sickness and died; daughter Rosalie remained in Belgium until she married and moved to Paris.
Shortly after their arrival in San Antonio, the entire family was stricken with malaria, and John and Joseph, Jr., died from the malady. With his remaining children, Joseph began the adjustment to the new homeland. Joseph found employment as a cook, while Frank took a job as a clerk. The stonemason, Theodore, found ready employment in the immediate neighborhood with the U.S. Army, which was in the process of adapting the Alamo for use as a Quartermaster's depot. Theodore later became a general contractor and constructed several of the early stone buildings of the city. Among these projects was stonework on the Menger Hotel, just outside the project area; Joseph was also employed to provide labor during the construction. As a result of this association, the Menger and Vanderstratten families became close friends. (Institute of Texan Cultures [ITC], Vanderstratten Family, Belgium, Folder 33, San Antonio, Texas).

On November 1, 1854, Theodore married Franciska Leznrick, a young Polish girl who had arrived with the first group of immigrants with Father Mocygemba. The union produced seven children, one of whom, Richard, became a long-time employee of Joske's Store at the corner of Commerce and Alamo streets. Richard's son was one of the leading architects of the city. Theodore constructed his own home on Blum Street, near the present location of La Quinta Inn. Shortly thereafter, an incident occurred concerning the property on Bonham Street that soured relationships within the family. In May 1856, Theodore filed suit against his father in District Court, charging that "Joseph is attempting to sell said property as his own and denies the right of the petitioner" (DCO, Vanderstratten suit, Bexar County Deed Records [BCDR], Volume N2:671, Bexar County Courthouse, San Antonio). The resultant suit concluded with the court ordering the house to be divided "through the middle of the partition wall" and 


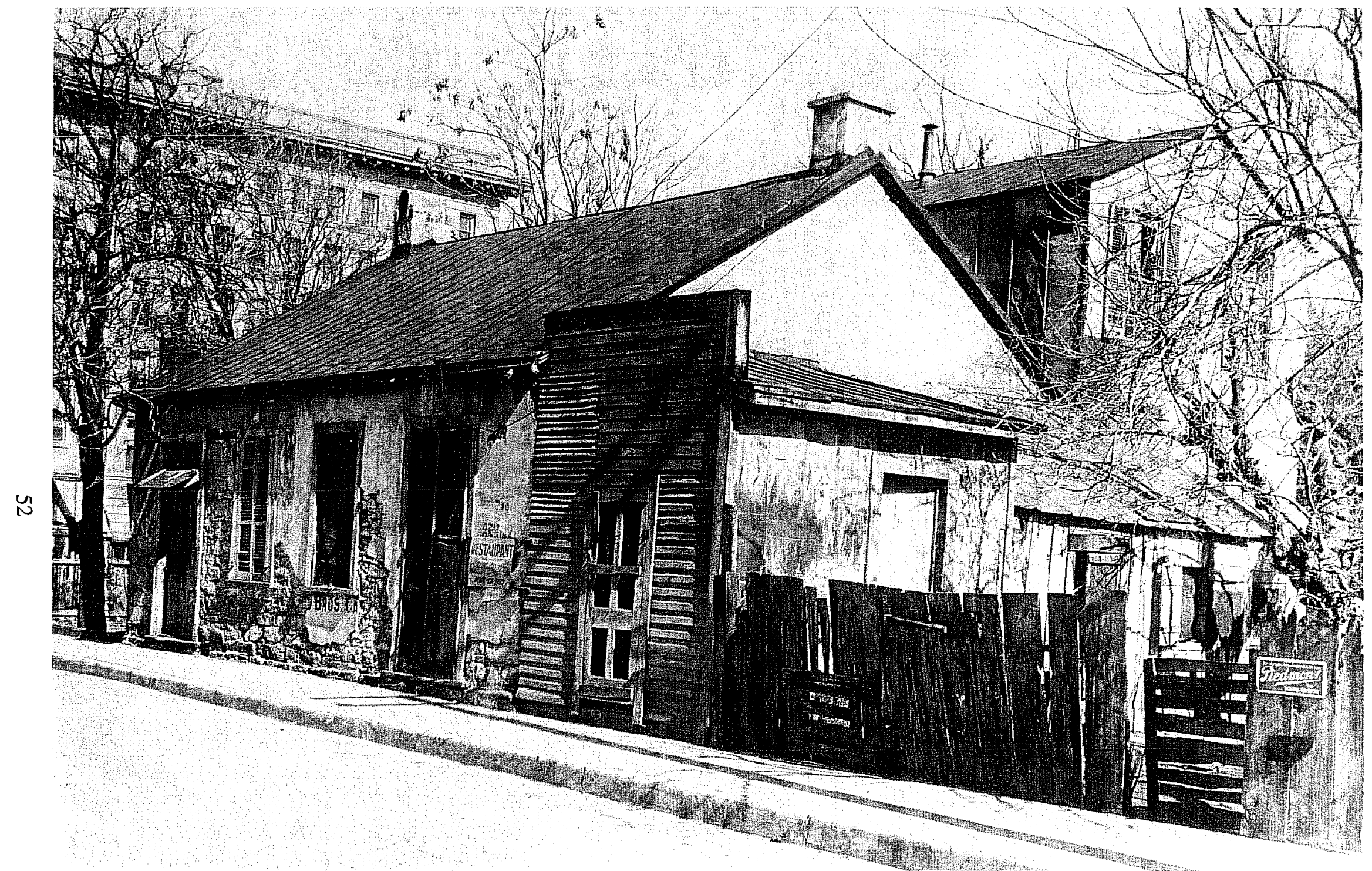

Figure 8-1. Vanderstratten house in 1921. Courtesy of the Institute of Texan Cultures: Mrs. Clara Christians. 
half awarded to each party (DCO, Vanderstratten suit, Bexar County Deed Records [BCDR], Volume N2:671, Bexar County Courthouse, San Antonio). Apparently, this rift was never fully healed, for when Joseph died, January 13, 1873, his will made no mention of Theodore, granted only $\$ 150$ to his daughter, and the remainder of the estate was awarded to the Menger family (DCO, Wills and Probate, Joseph Vanderstratten will). Joseph worked for year as a bartender in the Menger bar, and spent his last years living in the hotel, apparently as a guest of the Menger family. His portion of the homestead was granted to Gustav and Lewis William Menger.

When Theodore died, on October 3, 1895, his portion of the property passed to his children Richard and Louisa Vanderstratten, and Anna Christians, who sold the property to George R. Karges. Peter Gustav and Ida Menger then sold their portion to Sarah R. French (BCDR 99:120-121). The property by this time had become rental property, in 1898 it was occupied by Charles Beiring, a saloon keeper; Alexander Masson, a hay and grain dealer, and his driver, J. A. Newport; and the wooden addition on the south side was rented by Major Lynn, a black expressman (CD 1898). By 1912 the northern portion of the stone structure had become the Busy Bee Restaurant, a black establishment, and the remainder was black rentals (CD 1912). By 1918 the restaurant had become the Two Brothers Cafe, and the rental remained black (CD 1918). In 1921 the portion that had been the stone home was occupied by the Alamo Transfer Company, and occupied as a residence by its owner, Charles Bellinger, while the cafe had relocated to the wooden structure as the Original Home Kitchen (CD 1921-1923). In 1925 the structure was razed for the widening of Bonham Street.

Bellinger returned to the property in 1927 to operate the Bellinger Barber Shop at 212 Bonham. The new structure was smaller than the Vanderstratten home and consisted of a shop plus one small rental (210 Bonham), leased by Liller Jones in 1927. Although the buildings stood vacant for a time in 1934-1935, a restaurant was opened at 212 Bonham in 1936. Rosa's Petra Place Restaurant operated at the location until 1939. The property became a residence again in 1939 40, occupied by D. C. Piper. In 1942, Aldana Michel was the tenant, and by 1951 there is no listing for the property in the city directories.

\section{Archaeological Investigations}

\section{Testing of the Lot}

A backhoe test trench (Trench 1) was excavated northsouth through Lots $3 \mathrm{~A}$ and $3 \mathrm{~B}$, parallel to and $20 \mathrm{ft}$ from the curb line (Figure 8-2). This trench revealed a confusion of relatively shallow deposits of demolition rubble, sandstone slabs, postholes, river gravels, and caliche layers. No indications of building foundations were detected. Banded slip ware, sponged ware, and stoneware bottle sherds were found at a depth of 75-95 inches in this trench toward the south end, which places them near the Vanderstratten house.

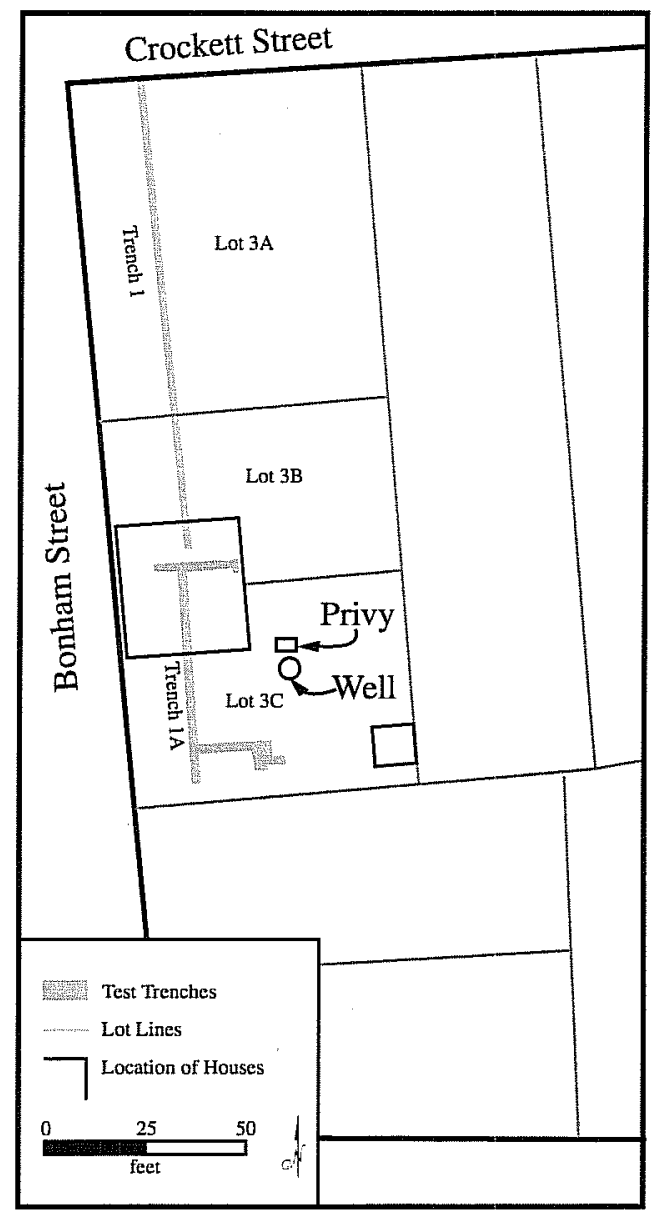

Figure 8-2. Location of Vanderstratten house on west end of NCB 166. 
Trench 1A was then excavated north-south across Lots $3 \mathrm{~B}$ and $3 \mathrm{C}$, where it was anticipated that the Vanderstratten house foundations would be found. When this trench did not locate any definite remains of the house or its later additions, it was enlarged with crosstrenches toward the east, which revealed a well and a privy in the backyard of the house site. Both features were excavated.

Since more than 25,000 artifacts were recovered from these two features, only select items are discussed in the artifact sections which follow. For the most part, our descriptions are limited to artifacts/ activity classes (ceramics, bottle glass, and personal items) that provide temporal data. We have also tried to highlight those artifacts that we believe can be attributed to individuals. For instance, a straight razor handle and leather strap holder from Level 3 of the well could be related to the 1927 barbershop owned by Charles Bellinger. We certainly recognize such information as being particularistic, but it frequently reinforced and refined our assumptions about the depositional histories of the features.

\section{The Vanderstratten Well}

A stone-lined well, assigned the field designation Feature IV-A, was identified under almost two feet of asphalt and gravel fill. The well was circular and measured 42 inches maximum width by 60 inches maximum length. It was excavated to a maximum depth of 133 inches below the surface (Figure 8-3). The original strategy was to excavate the northern portion of the feature while leaving the southern portion intact. Unfortunately, heavy rains caused the southern section to slump after the northern portion had been excavated to approximately 106 inches (Level 10) below

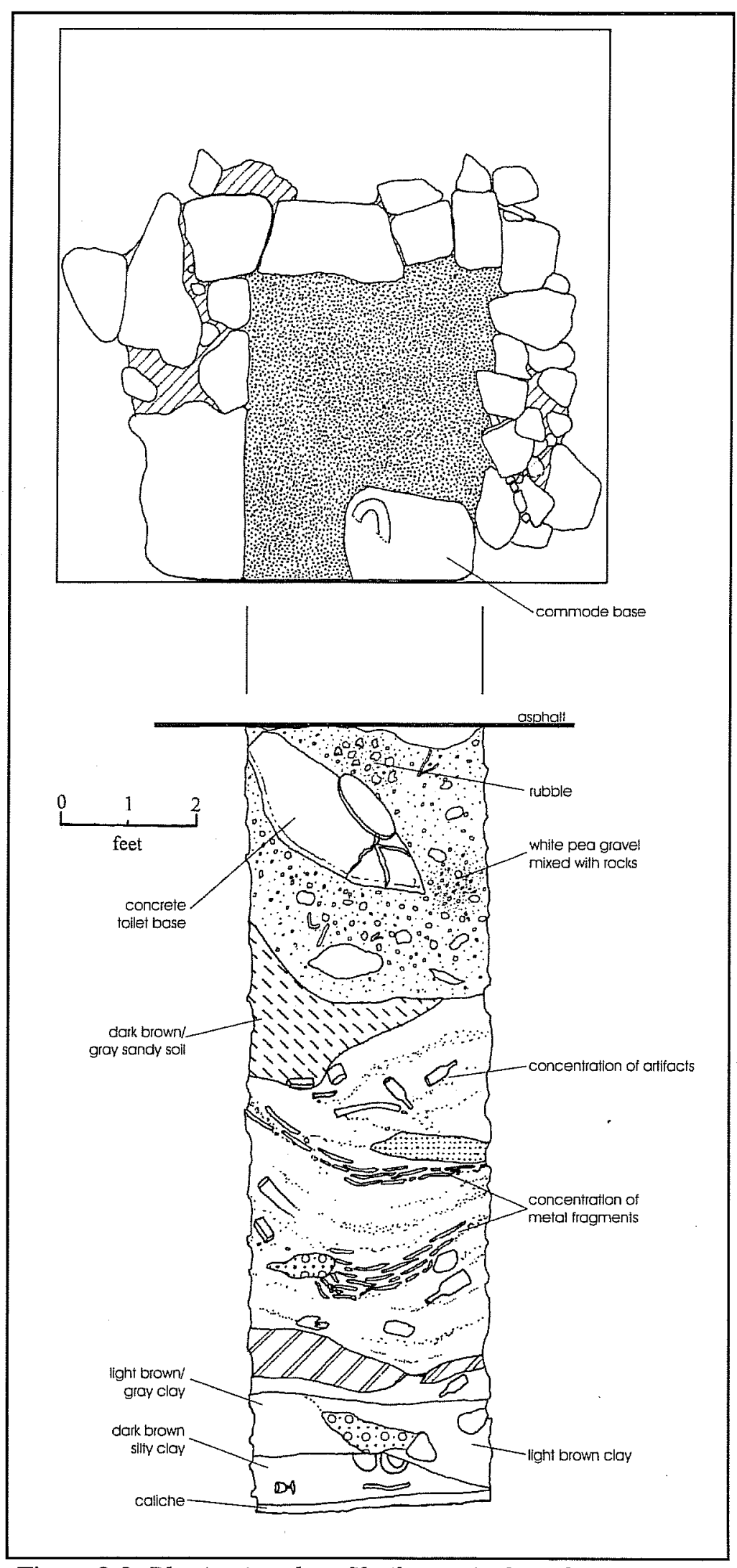

Figure 8-3. Plan(top) and profile (bottom) of Vanderstratten well. 
the surface. All of the cultural materials from the southern portion were collected as a single, unprovenienced unit. Although artifacts from the southern profile were not analyzed, some diagnostic artifacts are described below. Excavation of the northern portion resumed and continued until a culturally sterile horizon was encountered.

The well was excavated by stratigraphic levels as indicated by observed differences in soil color and texture. Fourteen levels were identified. The soils were generally described as moist, brown and gray clays with varying amounts of ash and charcoal, and limestone and caliche rubble.

\section{Well Artifacts}

Approximately 15,000 artifacts, not including 5,203 fragments of animal bone, were recovered from the Vanderstratten well. Table 8-1 lists the artifacts by artifact class/activity class and vertical provenience.

\section{Ceramics}

Nine hundred sixty-seven ceramic sherds were recovered from the well (representing 4.86 percent of all recovered artifacts). Undecorated whitewares was the most frequently observed type in the ceramic assemblage. The identifiable maker's marks indicate that a majority was produced by American manufacturers in the first two decades after the turn of the century. Table 8-2 shows the ceramics from the well by type and vertical provenience.

The following maker's marks were observed. There is a great deal of repetition; in fact, of the 44 identifiable marks, only 16 are unique. The marks are described below relative to their vertical provenience from bottom to top. Marks from the south profile slump are described separately. In instances where a mark was recovered from a provenienced level and the south profile, it is described by level to maximize temporal data. Similarly, when a mark was identified in multiple levels, it is discussed in the lowest level.
The Homer Laughlin Co. produced their "SEMIVITREOUS/ SELECT/ CHINA" mark between ca. 1901-1915 (Gates \& Ormerond 1982:135). Lehner (1988:249) believes 1905-1910 to be a more concise date of manufacture. The mark was recovered from Level 4. The most frequently observed mark was "K.T. \& K./S-V/CHINA." The mark was used by Knowles, Taylor, and Knowles of East Liverpool, Ohio, between 1870 and 1929 (Gates and Ormerond 1982:115). Lehner (1988:238-239) notes that the company filed this particular mark for registration on August 9, 1919 for table pottery, but had been claiming use on it since 1905. The mark was recovered from Levels 4, 5, 7, 8, 9,10 , and the south profile.

Lehner (1988:446-447) dates a "STEUBENVILLE/ CHINA" mark to the 1920 s. The mark was recovered from Level 8 and was crossmended with a sherd from Level 7. A second complete mark was also recovered from the south profile.

A partial mark with "...OHNSON BROS ... / ... GLAND" probably was produced by Johnson Brothers Ltd. of Hanley, England, from 1913 until an undetermined time (Godden 1964:355-356). The mark was found in Level 9 and in the south profile. One of the three Homer Laughlin marks identified from the well was marked "HOMER LAUGHLIN/HOTEL/ CHINA." Gates and Ormerond (1982:135) suggest a date of manufacture between 1901 and 1915. Other researchers, however, believe that the mark ceased to be used after 1904 (Lehner 1988:247). The mark was excavated from Levels 9 and 10. A partial mark bearing "MELLO..." was probably produced by the Mellor/Cook Pottery Co. between 1893 and 1930 (Lehner 1988:107). The mark was recovered in Level IO and in the south profile. Vodrey Pottery of East Liverpool, Ohio, used their "S-V/CHINAN.P. CO" mark in ca. 1922. The sherd was also excavated from Level 10. Finally, Lehner (1988:60-61) attributes a "DRESDEN/CHINA" mark to Brunt, Bloor, Martin, $\&$ Co (later the Potters Co-Operative Co.). The mark was used after 1900 for an unknown period of time. Gates and Ormerond (1982:39) indicate that there was a short-lived (1925-1927) Dresden Pottery Co. But their maker's mark does not correspond to our mark. 
Table 8-1. Artifacts from Vanderstratten Well

\begin{tabular}{|c|c|c|c|c|c|c|c|c|c|c|c|c|}
\hline Level & 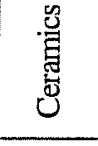 & $\frac{n}{\mathfrak{g}}$ & $\frac{\bar{D}}{\underline{\underline{E}}}$ & 弟 & $\underset{\text { 点 }}{\stackrel{.0}{E}}$ & 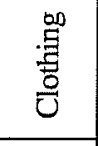 & 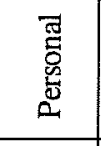 & 总 & 莺 & 总 & 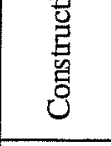 & Total \\
\hline surface & 23 & 4 & 1 & 15 & 1 & 2 & 0 & 1 & 6 & 1 & 41 & 95 \\
\hline 1 & 25 & 343 & 0 & 206 & 18 & 4 & 7 & 3 & 6 & 0 & 729 & 1341 \\
\hline 2 & 76 & 234 & 4 & 311 & 1 & 2 & 2 & 1 & 15 & 0 & 288 & 934 \\
\hline 3 & 132 & 1121 & 6 & 1112 & 145 & 29 & 6 & 6 & 4 & 4 & 793 & 3358 \\
\hline 4 & 205 & 2978 & 7 & 1117 & 156 & 52 & 10 & 20 & 21 & 2 & 297 & 4865 \\
\hline 5 & 34 & 467 & 4 & 127 & 14 & 1 & 0 & 2 & 19 & 0 & 180 & 848 \\
\hline 6 & 51 & 530 & 0 & 223 & 35 & 3 & 2 & 3 & 4 & 0 & 195 & 1046 \\
\hline 7 & 43 & 364 & 1 & 180 & 42 & 18 & 2 & 6 & 12 & 0 & 183 & 851 \\
\hline 8 & 60 & 159 & 1 & 61 & 30 & 18 & 0 & 2 & 7 & 0 & 247 & 585 \\
\hline 9 & 54 & 117 & 0 & 153 & 37 & 28 & 9 & 5 & 1 & 2 & 261 & 667 \\
\hline 10 & 91 & 150 & 0 & 214 & 74 & 15 & 0 & 0 & 3 & 1 & 127 & 675 \\
\hline 11 & 64 & 256 & 0 & 473 & 57 & 23 & 14 & 10 & 7 & 4 & 145 & 1053 \\
\hline 12 & 24 & 179 & 0 & 500 & 102 & 15 & 25 & 0 & 2 & 13 & 60 & 920 \\
\hline 13 & 20 & 155 & 1 & 210 & 101 & 13 & 1 & 0 & 2 & 1 & 146 & 650 \\
\hline 14 & 65 & 875 & 1 & 301 & 394 & 24 & 5 & 7 & 12 & 0 & 311 & 2015 \\
\hline Total & 967 & 7932 & 26 & 5203 & 1207 & 247 & 83 & 66 & 121 & 28 & 4023 & 19903 \\
\hline $\begin{array}{l}\% \text { of } \\
\text { Total }\end{array}$ & $4.86 \%$ & $39.85 \%$ & $0.13 \%$ & $26.14 \%$ & $6.06 \%$ & $1.24 \%$ & $0.42 \%$ & $0.33 \%$ & $0.61 \%$ & $0.14 \%$ & $20.21 \%$ & \\
\hline
\end{tabular}

Table 8-2. Ceramic Types from Vanderstratten Well

\begin{tabular}{|c|c|c|c|c|c|c|c|c|}
\hline Level & unglazed & dec. ww. & undec. ww. & yellowware & porcelain & stoneware & $\begin{array}{c}\text { over- } \\
\text { glaze }\end{array}$ & Total \\
\hline surface & 0 & 5 & 14 & 0 & 1 & 2 & 1 & 23 \\
\hline 1 & 0 & 0 & 13 & 0 & 10 & 0 & 2 & 25 \\
\hline 2 & 0 & 2 & 54 & 2 & 17 & 1 & 0 & 76 \\
\hline 3 & 0 & 90 & 4 & 1 & 29 & 6 & 2 & 132 \\
\hline 4 & 0 & 12 & 131 & 4 & 23 & 6 & 29 & 205 \\
\hline 5 & 0 & 5 & 24 & 0 & 0 & 1 & 4 & 34 \\
\hline 6 & 0 & 3 & 36 & 1 & 6 & 5 & 0 & 51 \\
\hline 7 & 0 & 3 & 28 & 5 & 0 & 5 & 2 & 43 \\
\hline 8 & 0 & 2 & 21 & 12 & 5 & 10 & 10 & 60 \\
\hline 9 & 0 & 0 & 42 & 0 & 4 & 8 & 0 & 54 \\
\hline 10 & 0 & 4 & 48 & 3 & 9 & 9 & 18 & 91 \\
\hline 11 & 0 & 52 & 29 & 1 & 3 & 8 & 21 & 64 \\
\hline 12 & 0 & 37 & 13 & 0 & 2 & 1 & 1 & 24 \\
\hline 13 & 0 & 36 & 11 & 0 & 3 & 0 & 0 & 20 \\
\hline 14 & 0 & 24 & 52 & 2 & 3 & 4 & 0 & 65 \\
\hline Total & 0 & 145 & 520 & 31 & 115 & 66 & 90 & 967 \\
\hline \% of Total & $0.00 \%$ & $14.99 \%$ & $53.77 \%$ & $3.21 \%$ & $11.89 \%$ & $6.83 \%$ & $9.31 \%$ & \\
\hline
\end{tabular}


A mark bearing "COLONIAL POTTERY/STOKE, ENGLAND" was excavated from Level 12. Godden believes that the mark was used between 1890 and 1925. Godden (1964:116) believes that Henry Burgess used the "STONE CHINA/H. BURGESS/ BURSLEM" mark between 1864 and 1892. The mark was recovered from Level 14. Several "J \& G MEAKIN/ HANLEY/ENGLAND" marks on 8 in plates and saucers were also recovered. Meakin used this mark after 1890 for an unspecified time. One Meakin mark from Level 14 was also crossmended with a sherd from Level 13.

The following five marks were recovered from the southern portion of the well. The Greenwood China Co. produced their "GREENWOOD CHINA/ TRENTON, N.J." mark between 1886 and 1910 (Lehner 1988:180). A "SMITH-PHILLIPS CHINA/ HOTEL" mark was produced by a company of the same name between 1901 and 1929 (Lehner 1988:430). A third Homer Laughlin mark was recovered from the south profile. This enduring "HOMER LAUGHLIN" mark was produced between ca. 1879 and 1956. There is evidence that the mark was registered on February 27, 1912 (Lehner 1988:247). Two European marks were also recovered from the south profile. A "PETRUS REG ... / MAASTRICHT/MERIDA/MADE IN HOLLAND" was produced between ca. 1887 and 1929 (Attenbury 1979:55). Finally, a mark bearing "ROYAL/ SEMIPORCELAIN/WOOD \& SON/ENGLAND" mark was manufactured between 1891 and 1907 (Godden 1964:689).

The total count for the ceramic assemblage includes 39 vessels which were either complete or at least 75 percent complete or reconstructable. A majority of the identified ceramic vessels were kitchen related items. Tablewares (Figure 8-4) included nine eight-inch plates, eight tea cups, six saucers, and one bowl. Food service items (Figure 8-5) included four small pitchers, two small serving trays, two small condiment/ vegetable dishes, and three jugs. Toiletwares included only one chamberpot lid. Utilitarian wares, all from the southern portion of the well, include three spittoons (Figure 8-6). The vessel form of the isolated sherds seem to approximate those of the identified vessels.

\section{Bottle Glass}

A total of 7,932 (39.85 percent of all artifacts) bottle glass fragments (glass stoppers) were recovered from the well. Included in this total are 460 complete or partial bottles. A surprisingly small number (25) of the bottles/sherds contained an identifiable maker's mark or stylistic attribute. Because of budget constraints, however, only a perfunctory examination of grossly obvious manufacturing characteristics that convey temporal data was attempted. The identified marks support our suggestion that the well was filled around 1920. The marks are described below in descending level.

Level I contained two bottles marked with an "I" enclosed by a circle and a diamond. This mark was used by the Owens-Illinois Pacific Coast Company of San Francisco from 1932 until 1943 (Toulouse 1971:406-407).

Two three-ounce Owens Bottle Company chemical bottles were recovered from Level 2 . The mark, an "O" enclosed in a square, was used on bottles produced from ca. 1911 to 1929 (Toulouse 1971:393-397).

Level 3 contained four previously described prescription bottles marked with "Alamo Drug Store/ A. Driess/San Antonio." Driess was in business from 1877 until 1906 (CDs1877-1906).

A Franzen and Son beer bottle (1900-1929) was recovered from Level 4 (Toulouse 1971:536-537). Two other beer bottles were identified from Level 4 . One an " $\mathrm{AB} \mathrm{Co} / 14 \mathrm{~S}$ " mark used by the American Bottle Company of Toledo from ca. 1900-1929 was found (Toulouse 1971:30-33). And, second, An "AB U 21 " mark attributed to the Adolphus Busch Glass Manufacturing Company was located. Toulouse (1971:26-27) believes that this particular mark was used between 1904 and 1907.

Two prescription bottles with Illinois Glass Co. maker's marks were recovered from Level 5 . The particular mark, "I" set within a diamond, was used between 1916 and 1929 (Toulouse 1971:264). Two 


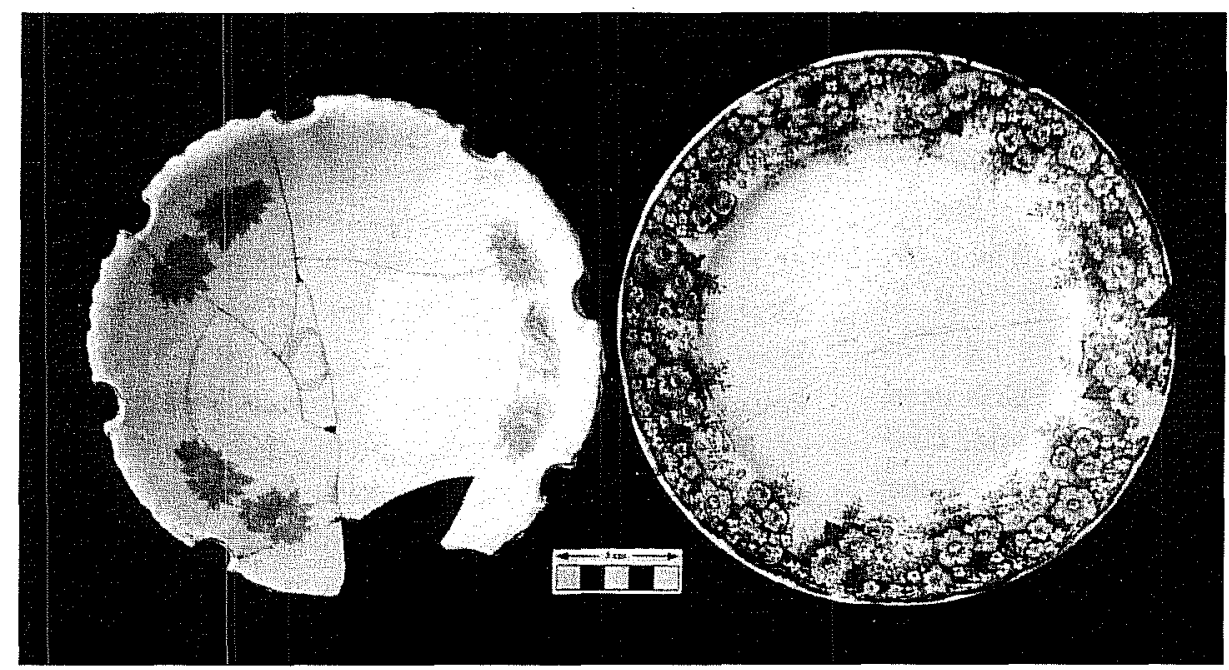

Figure 8-4. Porcelain dishes from the Vanderstratten well.

Figure 8-5. Pitchers and cups from the Vanderstratten well.

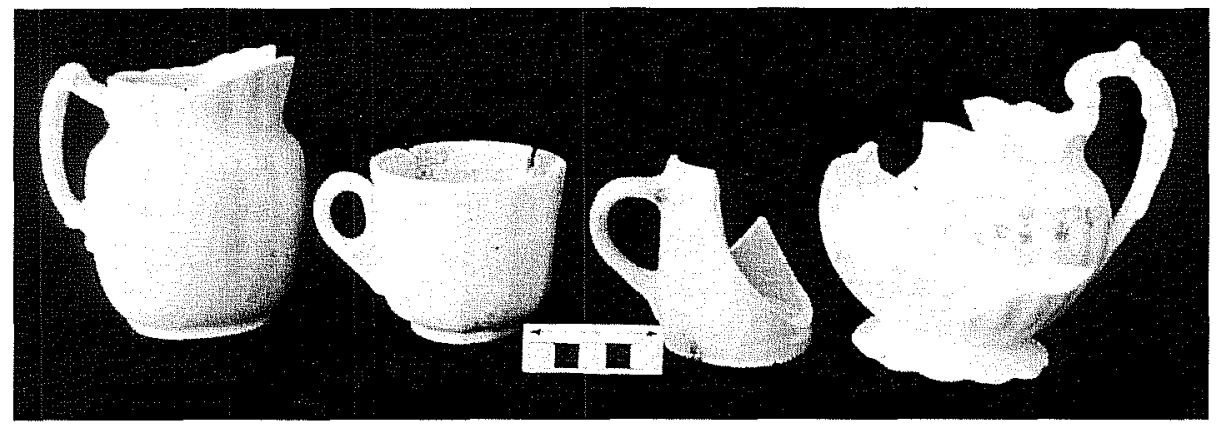

Figure 8-6. Ceramic spittoons from the Vanderstratten well.

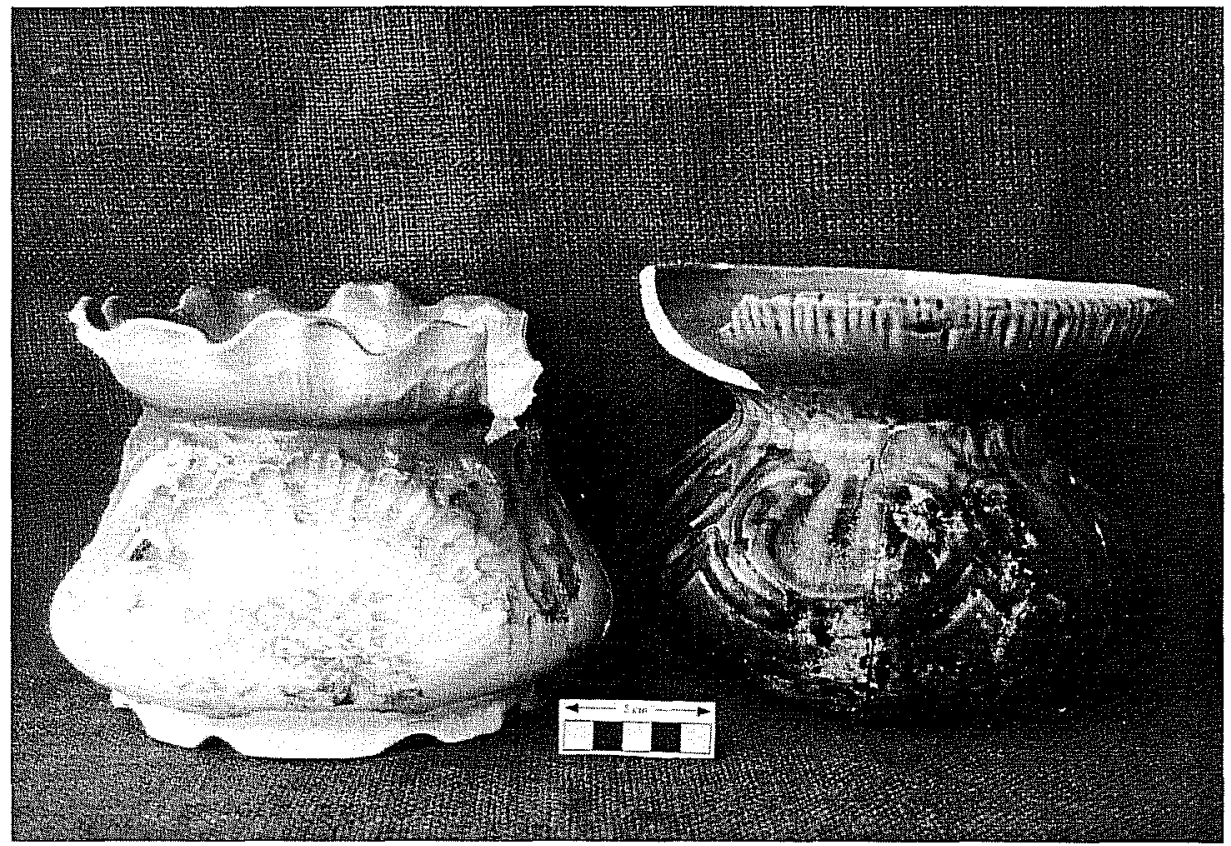


brown beer bottles marked with "WF \& S/MILW" were also found in Level 5. The mark was used by William Franzen and Son of Milwaukee, Wisconsin, between 1900 and 1929 (Toulouse 1971:536-537).

A Lea and Perrin condiment bottle marked with "JD/ S" was located in Level 6. John Duncan and Sons of New York City was the licensed American bottler for the sauce. The mark was used from ca. 1880 until 1900 (Toulouse 1971:277).

Two one-quart pickle jars were excavated from Level 8 . They are stylistically similar to those described by Munsey (1970:152-153): large necks and mouths with four side panels in a gothic arch design. Munsey suggests that these were produced from ca. 1870 to 1890.

Level 9 included a bottle marked with "R. Cohn \& Co./ Druggists/San Antonio, Tex." Ray Cohn owned a pharmacy originally on Buena Vista Street that later (ca. 1887) moved to Commerce Street and was in operation from 1883 until at least 1910 (City Directories 1883-1910). Four soda bottles marked with "AB Co" were also recovered from the level. Toulouse (1971:26) believes that the mark was used between 1904 and 1907.

An Adolphus Busch Manufacturing Co. mark "ABGM Co" - was identified from Level 11. This particular mark was used from 1886 until 1928 (Toulouse 1971:26).

Level 12 contained a local prescription bottle marked with "James Clavin Druggist." Clavin operated his drugstore at $144 \mathrm{~W}$. Commerce (corner of Navarro) from 1891 until 1906 (CDs 1877-1906). A Burlington "Hawk Eye Trademark" fruit jar was also recovered from the level. Toulouse (1971:97) suggests the mark was used from 1875 to 1909 .
One octagonal, umbrella-shaped ink bottle was recovered from Level 14. Munsey (1970:120) believes the bottle was produced between 1820 and 1880 . A bottle containing "Florida Water" and marked with "...PRAY \& LANMAN/DRUGGISTS/NEW YORK" was manufactured between 1865 and 1880 (Munsey 1970:157). Two bottles from local druggists were also excavated from Level 14. The first was marked with "A. Driess/Alamo Drug Store/San Antonio, TX." Adolphus Driess was in business from 1877 to 1906 (CDs 1877-1906). The second bottle was from "W. D'Albini/215 Alamo Plaza/San Antonio, Texas." D'Albini's drugstore was in business from 1887 until 1902 (CDs 1877-1902), Finally, a "D \& Ml" maker's mark was also recovered from Level 14. Davey and Moore, Ltd. was an English exporter of pickles and other food stuffs (Toulouse 1971:153).

The original contents (or function) of these bottles are presented in Table 8-3. Two observations can be made about the bottle glass assemblage from the well. First, bottle stoppers were frequently used with condiment bottles. Thus, it is likely that the large quantity of stoppers is a product of the site's use as a
Table 8-3. Contents of Bottles from the Vanderstratten Well

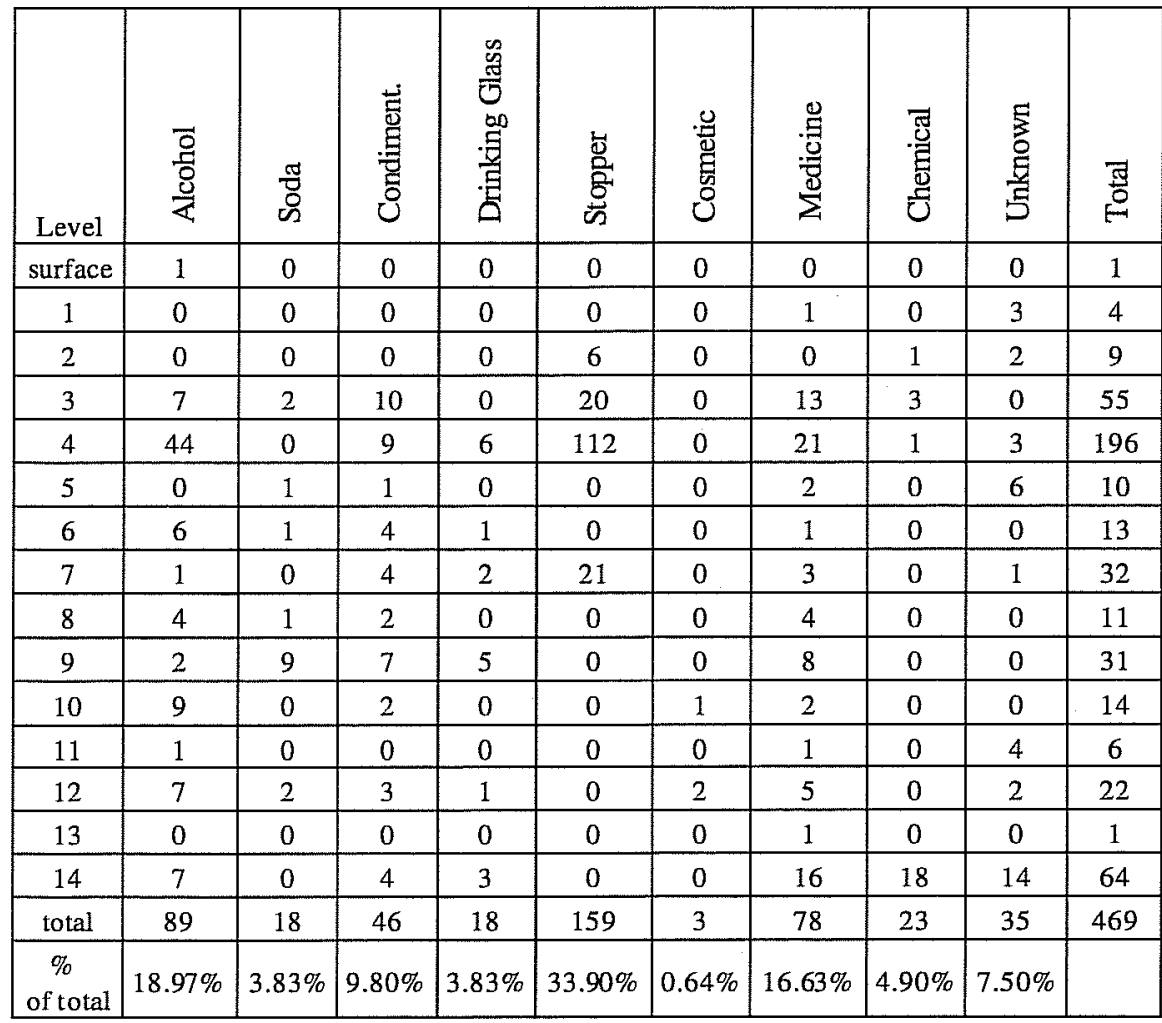


restaurant. Second, the absence of bitters bottles is indicative of post ca. 1910 sites. The bitters market began declining with the passage of the Pure Food and Drug Act of 1906. At the same time, the American Medical Association was vigorously trying to expose quackery and pharmaceutical fraud (Watson 1965:36).

\section{Personal Items}

Four coins and two tokens were recovered from the well. An 1894 Liberty Head nickel was found in Level 12. Level 11 contained an 1899 Liberty Head nickel and an 1899 Copper Indian Head penny. The two tokens were also excavated from Level 11. One token was marked with "A. Scholz/Palm Garden/San Antonio." The Palm Garden saloon was in business from 1895 until 1896 (CDs 1895-1901). The unidentifiable second token was only partially legible: "Good for 5 Tr ... /Two Cous ... ar..." Finally, no specific date for an Indian Head nickel from Level 2 could be determined. However, Indian Head nickels were produced between 1913 and 1938 (Yeoman 1967:94).

Two hundred forty-seven clothing items were recovered from the well. Shoe parts-heel and sole fragments and eyelets-were recovered from Levels $1,4,7,8,9,10,13$, and 14. Fragments from a lady's boot were recovered from Level 1.

Buttons constituted over 63.16 percent $(n=156)$ of the clothing assemblage. Shell reached its peak of popularity in America as a button composition in about 1900. Shell buttons, however, were produced from ca. 1860 until 1920 . These were the most frequently recovered type. Eighty-one shell buttons and 30 ceramic buttons were identified. Ceramic buttons were manufactured from the mid-nineteenth century until about 1920 (Pool 1987:289). Thirteen glass buttons were recovered. Glass was used for buttons from about 1840 until ca.1918.

Twelve vegetable ivory buttons were recovered. Vegetable ivory was popular from ca. 1870 until the early 1940s. Ten metal buttons, including one unidentified military button, were located. Metal buttons are poor temporal indicators as they have been produced continuously since at least 1800 (Pool 1987:289). Six composition buttons were also identified. Composition buttons - usually compressed glue and sawdust - were popular from about 1875 until the early 1920s. Finally, three bone buttons were excavated (Pool 1987:289). Bone was used throughout the nineteenth century until the middle 1920s. It is interesting that no plastic (including the early plastics, such as Bakelite, celluloid, and casein) or hard rubber buttons were recovered from the well. This seems to indicate that the well was filled prior to the late-1920s when these materials dominated the buttons industry (Pool 1987:289).

A few obvious feminine objects were identified. Level 12 contained a brassiere hook and douche bag and applicator. Fragments from two douche bags were also recovered from Level 11. A perfume stopper and a purse buckle were excavated from Level 4. As mentioned a lady's boot from Level 1 was identified. Our attempt to look for less obvious artifacts and/or artifact patterns that identify sex met with little success. To our knowledge, no excavations in south Texas have isolated a purely female-generated deposit that could function as a comparative database.

\section{Vanderstratten Privy Feature}

The remains of a square, cut limestone-lined privy were identified under $3.5 \mathrm{ft}$ of asphalt and gravel fill in a backhoe trench excavated in June 1984. The privy, designated Feature IV-B, was approximately 46 inches long and 44 inches wide. The upper portions of the privy were destroyed by demolition activities associated with the 1925 house razing and street widening. The existent portion of the privy was excavated to sterile soil at a maximum depth of 45 inches below the present surface.

The privy was excavated and recorded according to stratigraphic levels as indicated by observed differences in soil color and texture. Excluding a preparatory surface cleaning operation, eight levels were identified. The soils were generally described as dark brownish-gray clays with limestone and caliche rubble. 


\section{Privy Artifacts}

Approximately 7,676 artifacts were recovered from the privy. Table 8-4 presents all of the privy artifacts sorted by artifact/activity class and vertical provenience.

\section{Ceramics}

Four hundred sixty-three ceramic sherds were excavated from the privy (Table 8-5). A majority of the ceramic assemblage was comprised of undecorated whitewares ( $\mathrm{n}=322,69.55$ percent of total ceramics). Fortunately, a number of these bore identifiable maker's marks. The earliest possible range of dates is from a J. W. Pankhurst mark produced from 1850 1882 on a fragment from Level 7. The latest possible range of dates was found on a platter manufactured by the West End Pottery Company ("WEP Co./ CHINA") of East Liverpool, Ohio, between 1893 and 1910. The other maker's marks identified on undecorated whitewares were all produced sometime between the late 1850s and the middle 1880s. Since the "WEP Co." mark was recovered from Level 8, the bottom level of the feature, it is clear then that the marked ceramic assemblage could not have been deposited before 1893 .
Most of the decorated whitewares ( $n=58,89.23$ percent of all decorated whitewares) were recovered from Level 7. The decorated whitewares include one complete and two fragmented portions of a polychrome handpainted and spongeware child's tea cup with a rooster/chicken motif (Figure 8-7); three spatter/spongeware fragments, two executed in blue and one in red; and four blue cut-sponge fragments from a teacup. Also present were two transfer-printed sherds, including one large blue bowl rim fragment; 11 sherds from a partially reconstructed banded slipware bowl; a flow blue sherd, perhaps from a child's tea cup; one blue feather piece; and one completely reconstructed handpainted plate. A banded slip pitcher, reconstructed with 17 sherds, was also recovered from Level 7 (Figure 8-8).

Similar percentages/proportions of types (Tables 8-2 and 8-5) were found in both Features IV-A (the well) and IV-B (the privy), but the privy contained more European maker's marks while the majority of the marks from the well were from American manufacturers. Beginning in the last quarter of the nineteenth century, high protective tariffs and lower railroad rates allowed American manufacturers to compete with European producers. The less expensive American products also slowly gained prestige and

Table 8-4. Artifacts from the Vanderstratten Privy

\begin{tabular}{|c|c|c|c|c|c|c|c|c|c|c|c|c|}
\hline Level & 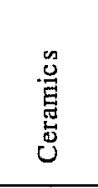 & 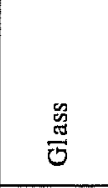 & 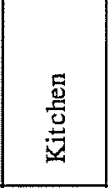 & 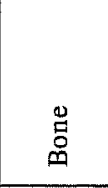 & 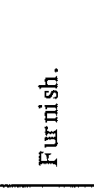 & $\begin{array}{l}\text { 昌 } \\
\text { 总 } \\
\text { 总 }\end{array}$ & 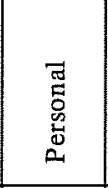 & 意 & 㽞 & 葛 & 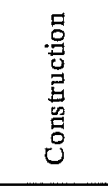 & Total \\
\hline surface & 8 & 3 & 1 & 0 & 0 & 0 & 0 & 2 & 0 & 0 & 6 & 20 \\
\hline 1 & 3 & 32 & 0 & 88 & 1 & 0 & 0 & 0 & 0 & 0 & 18 & 142 \\
\hline 2 & 83 & 1062 & 0 & 0 & 8 & 3 & 1 & 27 & 5 & 2 & 200 & 1391 \\
\hline 3 & 28 & 530 & 0 & 250 & 18 & 6 & 0 & 8 & 6 & 0 & 55 & 901 \\
\hline 4 & 25 & 259 & 0 & 210 & 8 & 1 & 0 & 2 & 4 & 0 & 39 & 548 \\
\hline 5 & 108 & 721 & 2 & 624 & 68 & 14 & 2 & 5 & 5 & 1 & 104 & 1654 \\
\hline 6 & 22 & 88 & 0 & 407 & 9 & 0 & 0 & 1 & 1 & 2 & 262 & 792 \\
\hline 7 & 170 & 350 & 0 & 1024 & 159 & 16 & 1 & 5 & 12 & 0 & 72 & 1809 \\
\hline 8 & 16 & 202 & 0 & 127 & 12 & 4 & 1 & 0 & 6 & 0 & 51 & 419 \\
\hline Total & 463 & 3247 & 3 & 2730 & 283 & 44 & 5 & 50 & 39 & 5 & 807 & 7676 \\
\hline $\begin{array}{l}\% \text { of } \\
\text { Total }\end{array}$ & $6.03 \%$ & $42.30 \%$ & $0.04 \%$ & $35.57 \%$ & $3.69 \%$ & $0.57 \%$ & $0.07 \%$ & $0.65 \%$ & $0.51 \%$ & $0.07 \%$ & $10.51 \%$ & \\
\hline
\end{tabular}


Table 8-5. Ceramic Types from Vanderstratten Privy

\begin{tabular}{|c|c|c|c|c|c|c|c|c|}
\hline Level & unglazed & dec. ww. & undec. ww. & yellowware & porcelain & stoneware & over-glaze & Total \\
\hline surface & 0 & 0 & 3 & 0 & 1 & 3 & 1 & 8 \\
\hline 1 & 0 & 0 & 3 & 0 & 0 & 0 & 0 & 3 \\
\hline 2 & 0 & 2 & 77 & 0 & 4 & 0 & 0 & 83 \\
\hline 3 & 0 & 1 & 21 & 0 & 5 & 0 & 1 & 28 \\
\hline 4 & 0 & 2 & 19 & 0 & 3 & 1 & 0 & 25 \\
\hline 5 & 0 & 0 & 103 & 0 & 4 & 0 & 1 & 108 \\
\hline 6 & 0 & 1 & 12 & 0 & 9 & 0 & 0 & 22 \\
\hline 7 & 0 & 58 & 73 & 4 & 22 & 2 & 11 & 170 \\
\hline 8 & 0 & 1 & 11 & 0 & 0 & 3 & 1 & 16 \\
\hline Total & 0 & 65 & 322 & 4 & 48 & 9 & 15 & 463 \\
\hline \% of Total & $0.00 \%$ & $14.04 \%$ & $69.55 \%$ & $0.86 \%$ & $10.37 \%$ & $1.94 \%$ & $3.24 \%$ & \\
\hline
\end{tabular}

acceptance and, by the early twentieth century they were seriously competing with the Europeans (Gates \& Ormerod 1982:10). Thus, the marks may attest to the privy fill being generally older than that of the well.

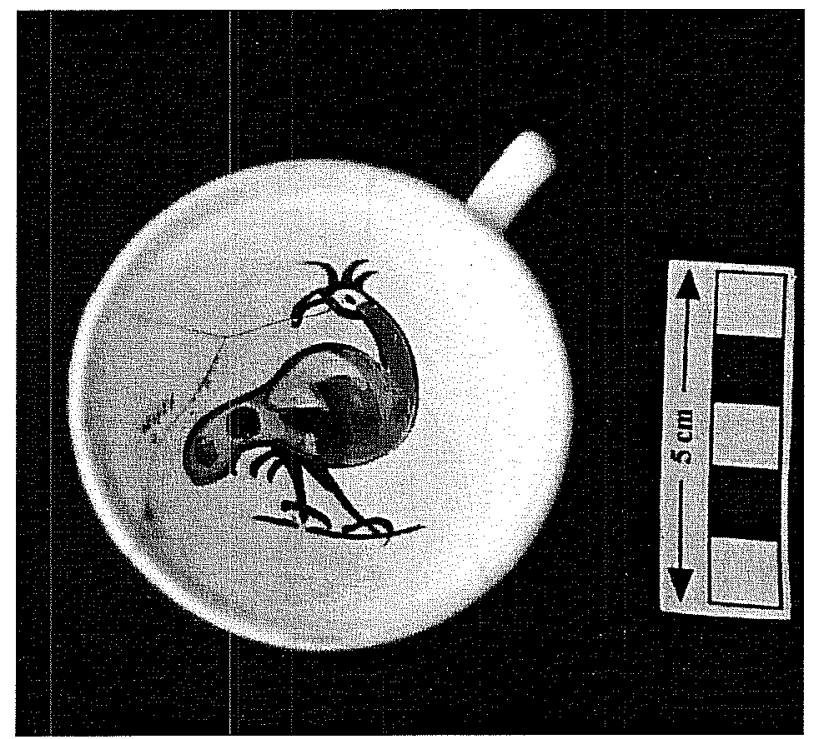

Figure 8-7. Child's teacup from Vanderstratten privy.

Thirty-five vessels were found either complete or mostly complete, or were reconstructed in the laboratory. Of these, eight chamberpots, three chamberpot lids, and two bath pitchers were identified. Six cosmetic jars were also recovered. The remaining vessels were kitchen-related items, including three plates, three saucers, four tea cups, a demitasse, one bowl, a serving tray, two table pitchers, and a tureen.
It is interesting that so many bath-related items were recovered. In addition to the aforementioned toiletware, at least five other chamberpots could be identified. Perhaps, then, this suggests that the privy was selectively filled with items considered appropriate for a privy even after it no longer served its original function or purpose.

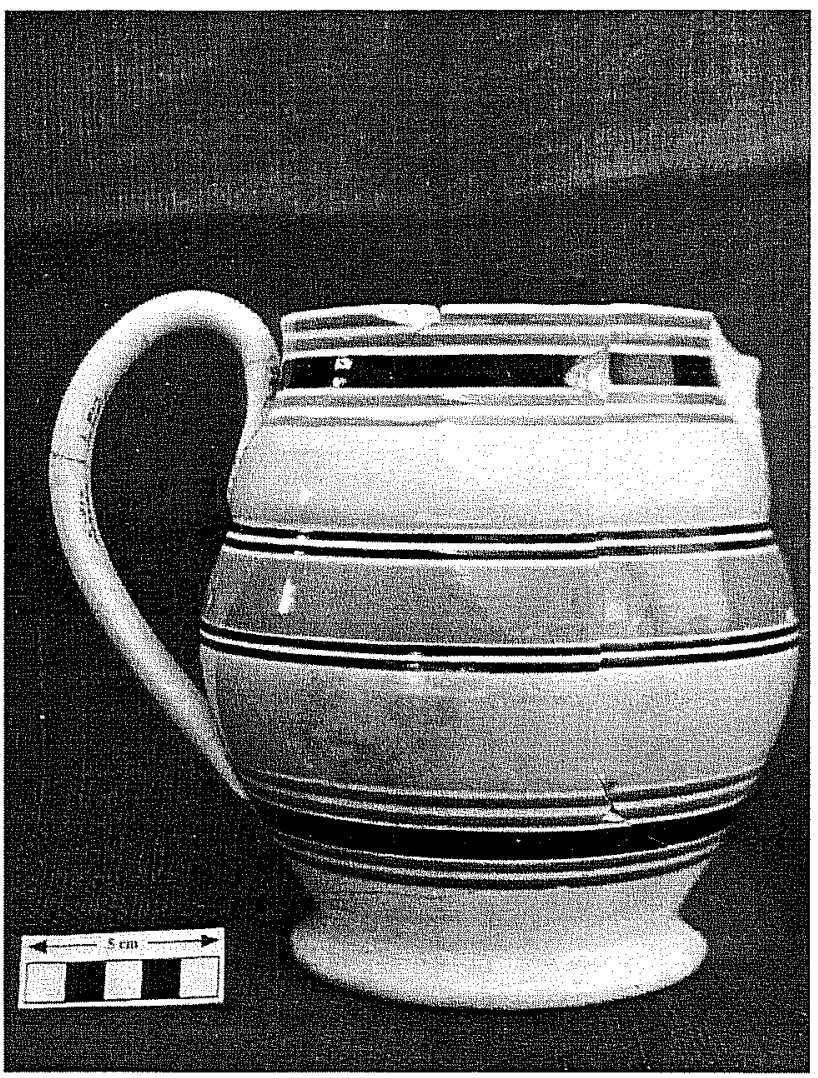

Figure 8-8. Banded slipware pitcher from privy. 
Five vessels and a base with an identifiable maker's mark were all reconstructed with crossmended sherds. An undecorated whiteware chamberpot and lid, both with a raised wheat and corn design, were fully reconstructed with sherds from Levels $1,2,3,4$, and 5. A small, undecorated whiteware pitcher was reconstructed with sherds from Levels 1 and 2. Godden (1964:495) dates the Pinder, Boume, and Company's maker's mark between 1862 and 1882. An undecorated whiteware pitcher was partially reconstructed with sherds from Levels 2 and 3. Sherds from Levels 2 and 3 were crossmended, revealing a Powell and Bishop maker's mark produced between 1876 and 1878 (Godden 1964:509). A rim fragment of an undecorated whiteware cosmetic jar was crossmended with a rim fragment from Level 5. And finally, an undecorated whiteware plate was reconstructed with sherds from Levels 5, 6, and 7 .

\section{Bottle Glass}

A total of 3,247 bottle glass fragments (Table 8-4) was recovered from Feature IV-B (representing 42.30 percent of all artifacts recovered from the privy). Included in this number are 116 whole or reconstructed bottles. The original contents or function of these 116 bottles are presented in Table 8-6. Little temporal data, however, was gained from the glass assemblage. Only 14 bottles contained an identifiable maker's mark.

Four brown alcohol bases and one complete bottle with "MG Co." marks were recovered from Level 2. Toulouse (1971:359361) suggests the marks could be from either Millgrove Glass Co. (1898-1911) or Modes Glass Co. (1895-1904). Another complete brown alcohol bottle with "MG Co." on the base was recovered from Level 3.
One brown bitters base with " $\mathrm{C} \& \mathrm{I}$ " was found in Level 2. C \& I is probably the mark used by Cunningham(s) and Ihmsen of Pittsburgh between 1865 and 1879 (Toulouse 1971:132-133).

One partial Dr. Hostetter's bitters bottle with 'L \& W" on the base was excavated from Level 3. Toulouse (1971:338-339) believes that Lorenz and Wightman of Pittsburgh used the mark between 1851 and 1860 and then again from 1862 until 1871. Watson (1965:136-137) also believes that Lorenz and Wightman manufactured bottles for Hostetter. Two more " $\mathrm{L} \& \mathrm{~W}$ " bases were found in Level 4.

One complete and one near-complete brown Dr. Hostetter's bitters bottles with "WMCC \& Co" on the bases were located in Level 4. The mark was used by William McCully \& Company between 1841 and 1886 (Toulouse 1971:35 1). Two more partial bottles with the "WMCC \& Co" were found in Level 5.

\section{Personal Items}

Twenty-five buttons were recovered from the privy. The buttons represent 56.82 percent of the clothing assemblage. They were composed of the following
Table 8-6. Contents of Bottles from Vanderstratten Well

\begin{tabular}{|c|c|c|c|c|c|c|c|c|c|c|}
\hline Level & $\begin{array}{l}\overrightarrow{0} \\
\frac{\mathrm{C}}{0} \\
\stackrel{0}{4}\end{array}$ & $\begin{array}{l}\stackrel{\pi}{\circ} \\
\stackrel{0}{\circ}\end{array}$ & 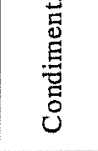 & 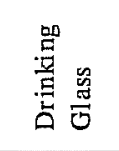 & $\begin{array}{l}\text { 㟔 } \\
\text { 号 } \\
\text { 品 }\end{array}$ & 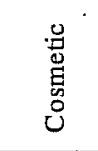 & 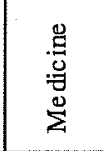 & 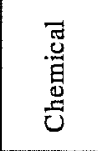 & 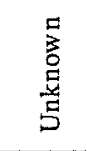 & 丞 \\
\hline surface & 1 & 0 & 0 & 0 & 0 & 0 & 0 & 0 & 0 & 1 \\
\hline 1 & 4 & 0 & 0 & 0 & 0 & 0 & 1 & 1 & 4 & 10 \\
\hline 2 & 18 & 1 & 2 & 0 & 0 & 0 & 2 & 0 & 2 & 25 \\
\hline 3 & 4 & 1 & 1 & 2 & 0 & 0 & 1 & 1 & 2 & 12 \\
\hline 4 & 6 & 0 & 1 & 0 & 4 & 0 & 0 & 0 & 4 & 15 \\
\hline 5 & 8 & 0 & 2 & 11 & 0 & 0 & 2 & 1 & 3 & 27 \\
\hline 6 & 3 & 0 & 0 & 0 & 1 & 0 & 1 & 0 & 0 & 5 \\
\hline 7 & 9 & 0 & 0 & 3 & 2 & 0 & 4 & 3 & 0 & 21 \\
\hline 8 & 4 & 0 & 0 & 1 & 1 & 1 & 0 & 0 & 0 & 7 \\
\hline total & 57 & 2 & 6 & 17 & 8 & 1 & 11 & 6 & 15 & 123 \\
\hline $\begin{array}{l}\% \text { of } \\
\text { total }\end{array}$ & $46.34 \%$ & $1.63 \%$ & $4.88 \%$ & $13.82 \%$ & $6.50 \%$ & $0.81 \%$ & $8.94 \%$ & $4.88 \%$ & $\begin{array}{c}12.20 \\
\%\end{array}$ & \\
\hline
\end{tabular}


materials: 14 glass, 2 metal, 2 ceramic, 4 shell, 2 metal/ leather covered, and 1 hard rubber. Unfortunately, none of the buttons was temporally or functionally diagnostic. All were manufactured sometime between the early 1840s and ca. 1915 (Pool 1987:289).

\section{Toys}

Children were present at the site as reflected by the presence of toys or amusements. Only gross dates could be assigned to these, however. Three separate doll fragments are similar to those popular around the turn of the century (Barbara Meissner, personal communication 1994). Three fragments from a handpainted bisque doll face were excavated from Level 5. Fragments of a second porcelain doll's head and arm were found in Level 6. They are part of a "china limb" doll that would have had a cloth body. She is probably a "shoulderhead" doll (i.e., head and shoulders molded together). The head size seems to indicate that the doll stood about 7.5 inches. A similar type doll would have cost less than three cents at the turn of the century (Stirn 1990:10). A third doll's head/face was recovered from Level 7. The doll was well made as evidenced by careful molding and painting. Less diagnostic doll fragments were also recovered from Levels $1(n=1), 2(n=1), 4$ $(n=1)$, and $7(n=3)$.

A unglazed marble with intersecting sets of green and red parallel lines from Level 3 was probably produced in what Carskadden and Gartley $(1990: 17,79)$ refer to as the early period (1846-1870). An unidentified glass marble was also recovered from Level 7. Finally, four pieces of slate and a slate pencil from Level 3 may also have been used by a child. And finally, a tricycle wheel was also recovered from Level 4.

\section{Discussion}

Possibly the first house built in the project area, the Vanderstratten house had a long and varied life between its construction in 1850 and its demolition for the widening of Bonham Street in 1925. Only eight years after it was completed, the house was effectively divided in half by court order, and the underlying rift between father and son was never healed. As a result, the property underwent numerous changes of occupants including a barber shop, several cafes, and a moving company as well as occasionally housing a family.

The well appears to have been filled with household trash within a very short time period. This may have been the result of the demolition of the structures for the street widening. However, the fact that the trash is definitely household and cafe-related suggests that it was the result of emptying the buildings and cleaning up the yard before demolition began.

The privy in the back yard was probably built and first used by the Vanderstrattens, since it was stonelined. The small number of pre-1858 artifacts in the two bottom levels may have been deposited during this earlier period and somehow overlooked during the first privy cleaning activities required by law starting in the 1880s (Brown and De La O 1997). Since the artifacts in the upper levels could confidently be dated to the end of the nineteenth century based on the ceramics, it appears that the privy was intentionally filled within a short time period, perhaps in one event related to the cleaning out of a nearby structure when plumbing was installed.

Excavation of these features in the mitigation phase of the project produced numerous datable artifacts which suggest that the well was filled between ca. 1900 and 1925, and privy between ca. 1900 and 1910. During these time periods, the site was used by a number of African-Americans for residential and commercial purposes. This raises a number of research questions critical to our understanding of African-Americans' role in San Antonio's development. What demographic factors influenced the use of the property for commercial endeavors? How did black entrepreneurship develop in the city? What, if any, economic limitations constrained African-American home ownership? Were consumer choice decisions driven by individual, cultural, economic, or market preferences? Furthermore, the deposits demand that we evaluate our criteria to detect gender and age in the archaeological record. How do we move beyond the simple, stereotypical indicators such as perfume and toys? Unfortunately, we are currently unable to answer any of these questions. The necessary comparative data simply do 
not exist for San Antonio and South Texas. Our artifact discussions, then, are an attempt to begin the process of collecting and organizing data that can be used by future researchers.

A perfunctory examination of the vertical provenience of the privy artifacts seems to indicate stratified deposits: extremely high artifact densities were observed in Levels 2, 5, and 7 and these were separated by much thinner deposits. A careful examination of the artifacts, however, suggests that the individual levels do not represent discrete deposits. Instead, there is evidence of a two poorly defined and slightly mixed fill episodes. Levels 1 through 6 contain a large number of crossmended artifacts, possibly indicating a quick, intensive deposit that dates from the first decade of the twentieth century. Levels 7 and 8, however, contain earlier artifacts mixed with lesser amounts of the later artifacts that had been recovered from the upper levels and appears to have deposited in the earlier years of the nineteenth century.

Most of the artifacts recovered from the privy consistently have dates of manufacture from around the turn of the century. Ceramics, diagnostic bottle glass and other select items that provide temporal data are described below. Utilizing a variety of archival and documentary sources, we have been able to attribute the artifacts to specific individuals with reasonable success.

The Vanderstratten house had been converted into a duplex (210 and 212 Bonham Street) well before the turn of the century (Figure 8-1). Using the San Antonio city directories, all of the past residents, for both rental units, were identified from 1900 through 1915. The property was rented by several African-American families and individuals for very short periods of time.

The property also housed many commercial establishments which were also owned by AfricanAmericans. In 1903-1904, Robe(rt) O'Neil, a porter, lived at 210 Bonham, while J. B. Griffin's Alamo Moving Company was located at 212 Bonham. In 1905-1906, Grant Jackson, identified as a laborer, lived at 210 Bonham and a widow, Mattie Jackson, lived at 212 Bonham with her three children. Mattie Jackson moved almost yearly after her husband died in ca. 1895. But Mattie Jackson continued to live at the same address through 1908 and Tillie Shoaf, who appears in the city directories only for that one year, lived next door at 210 Bonham with four other (unspecified) persons, presumably her children. By the time the next directory was published in 1909, 210 Bonham was occupied by A. Williams, and 212 Bonham was being used as a restaurant by Wiley Anderson. Anderson did not live at the property; his house was on Dawson Street. In 1910, 210 Bonham was vacant. In that same year, a barber shop and pool hall were both located in 212 Bonham. Pleas Walker was identified as the barbershop owner and Anderson was now the pool hall owner. Neither man lived on the premises.

Comparisons to three privies with contemporaneous deposits excavated as a part of the Alamodome project (Brown and De La O 1997) and one other privy from the Las Tiendas project reveals that the Vanderstratten privy contained significantly more bottle glass and less construction debris (Table 8-7). The high bottle glass counts ( $n=3247,42.30$ percent of total artifacts) may again indicate that the upper six levels of the privy were filled while the property was being used for commercial purposes, and before any extensive construction or demolition activities in the area.

Table 8-7. Privy Content Comparison

\begin{tabular}{|c|c|c|c|c|c|c|c|c|c|c|c|}
\hline Site & 畹 & 袩 & 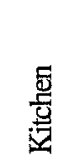 & ஜั & 兽 & $\begin{array}{l}. \stackrel{3}{0} \\
\text { 总 }\end{array}$ & 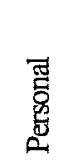 & 总 & 睱 & 亘 & $\begin{array}{l}\text { 명 } \\
\text { 总 } \\
\text { 苟 }\end{array}$ \\
\hline $41 \mathrm{BX} 883$ & 2.09 & 14.32 & 0 & 38.16 & 12.26 & 0.94 & 0.21 & 0.26 & 0.23 & 0.02 & 30.52 \\
\hline $41 B \times 896$ & 5.23 & 20.35 & 0 & 9.76 & 3.54 & 0.89 & 0.67 & 0.36 & 0.75 & 0.04 & 51.39 \\
\hline $41 B \times 945$ & 2.67 & 14.64 & 0 & 47.9 & 1.46 & 0.96 & 0.22 & 0.47 & 2.84 & 0.9 & 27.59 \\
\hline 41BX635 & 4.72 & 14.75 & 0 & 29.95 & 0.94 & 2.88 & 3.88 & 0.27 & 0.38 & 0.03 & 42.15 \\
\hline 41BX634 & 6.03 & 42.3 & 0.04 & 35.57 & 3.69 & 0.57 & 0.07 & 0.64 & 0.51 & 0.07 & 10.51 \\
\hline
\end{tabular}




\section{Chapter 9: The Faska Site}

Site Identification: The Faska Site, NCB 1010, Lot 1

Address: 301 E. Commerce Street

Trinomial: $41 B \times 635$

\section{Historical Background}

The structural and occupational history of 41BX635 is complex: early construction activities and occupations are not well documented, and several short, multiple-family/commercial occupations occurred in the twentieth century. Ignatz and Marie Faska purchased the site from John and Anita Withers on October 2, 1865, for \$500 (BCDR T2:73). Augustus Koch's 1873 Bird's Eye View of the City of San Antonio indicates that the street front (301 E. Commerce Street) was vacant, but that a small one-story structure was located on the back (north) portion of the lot. Comparisons with the 1904 Sanborn Insurance Company map, however, suggest that the structure on the earlier map was an adobe outbuilding on an adjacent lot (Lot 2). An aerial map of San Antonio depicts a two-story structure in place at $301 \mathrm{E}$. Commerce in 1886 . Thus, the two-story dwelling (Figure 9-1) must have been constructed between 1873 and 1886. The house's existence is also supported by party wall agreements between the Faskas and Julia Richter and Angelo Battaglia at 303 East Commerce Street (41BX641) in 1888 and 1894, respectively (BCDR 60:8; BCDR 130:99). A privy was also identified on the 1877 and 1885 maps. Later maps suggest that the privy structure was removed between 1885 and 1892.

Ignatz (listed as Ignacio and Ignatto on various documents) Faska was born in Prussia (Poland) in 1833. There is record that he worked as a carpenter for most of his life. He married Marie (also listed as Mary), who was born in 1838, sometime before 1860 (U.S. Census 1860). Ignatz and Marie had five daughters: Bridgett (born in 1858), Mary (born in 1862), Anna (born in 1863), Julia (born in 1867), and Louisa (born in 1869). Marie Faska died from unknown causes at the age of 67 on January 14, 1905.
Records indicate that Marie's estate (valued at $\$ 771.30$ ) was evenly divided between her daughtersBridgett Wagner, Mary Pavalek, Annie Zizik, Julia Niklass, and Louis Aniol. Although there is record that Ignatz was still alive in ca. 1901-1902 (City Directories), he may have preceded her in death since he was not listed as Marie's heir.

There is no record that Ignatz or Marie ever lived at the site. A review of city directories revealed that they lived at 403 North Street (at the corner of Matagorda Street) from 1877 until 1902. Ignatz's brother, Jacob, did live at the site for one year, in ca. 1877-1878. Thereafter, he moved twice in the next four years before finally settling at 403 Plum Street (at the corner of Dakota Street), where he and his family stayed until at least 1901-1902. Thus, Ignatz and Mary rented out the structure at $301 \mathrm{E}$. Commerce.

In 1895 the Faskas sold the property "with improvements" (i.e., the house and any associated outbuildings) to Henry and Fredrica Bohn (BCDR 141:144). It is uncertain if the Bohns resided at the site or if they too used it as a rental property. There is record, however, that by 1898 , Diedrich Heye, a harness maker, was living in the building at $301 \mathrm{E}$. Commerce Street.

Beginning at the turn of the century, a succession of tenants was recorded at the site. To assist in the identification of artifacts, a detailed list of select, known tenants follows. Between 1903 and 1906, the Collins and Jenkins Saloon operated at the site. In 1908 the structure was occupied by the Model Tailors, operated by W. L. Baker. Baker shared the structure with a shoemaker, Joe A. Rawlins. The following year, Baker's tailor shop was joined by the Dixie Loan Company, with W.C. Forsyth as manager, and a J. A. Rollins was now offering "hardware specialties" (CD 


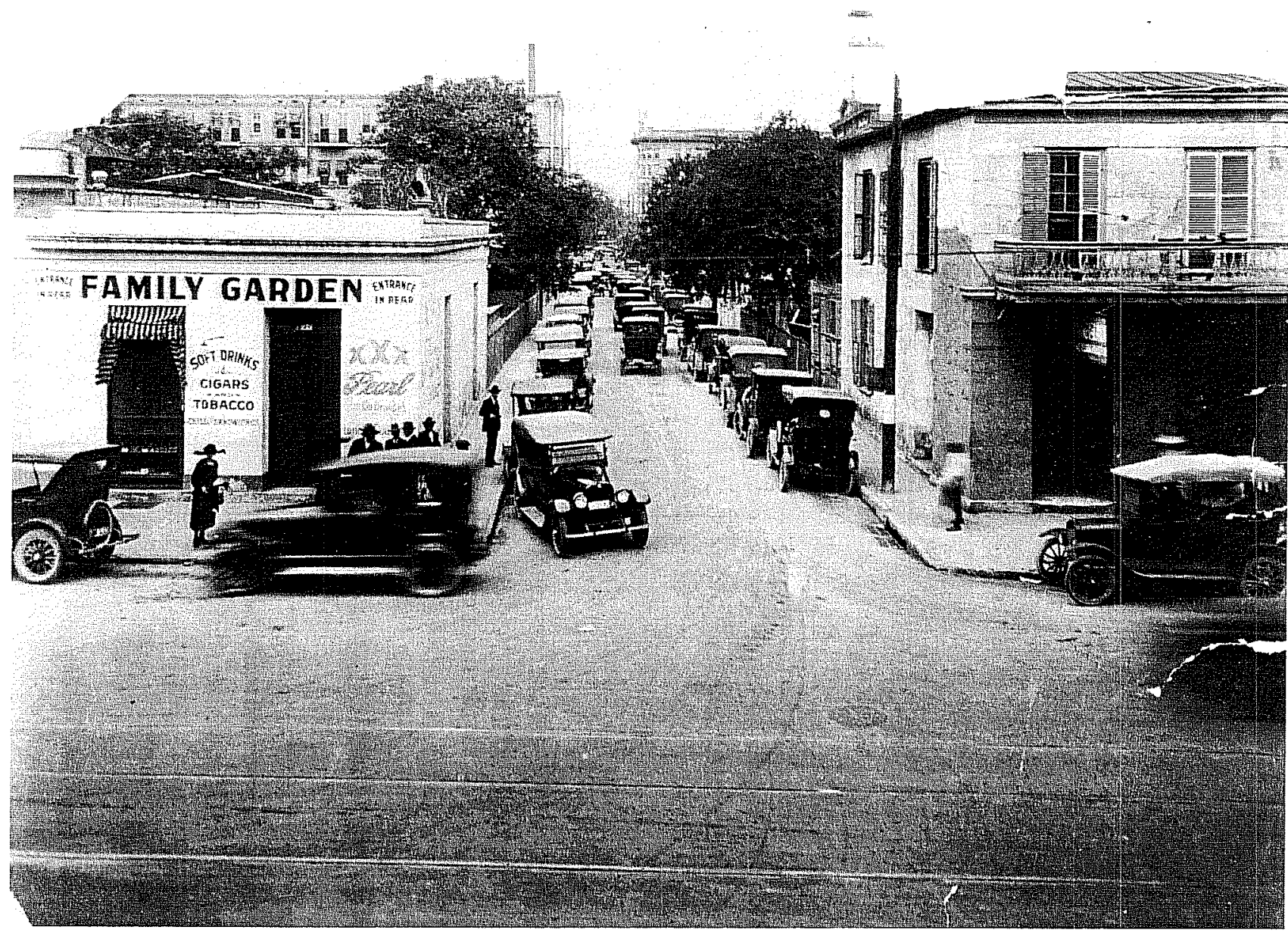

Figure 9-1. The Faska building, on the right, in the 1920s. (The Institute of Texan Cultures, San Antonio, Texas. Courtesy: Clare Bass.)

1909). Despite the similarity of names, Rawlins and Rollins appear to be different individuals as indicated by their listed addresses in city directories. By 1910 , the business tenants remained the same, but there was the additional listing of a domestic rental at $301 \frac{1 / 2}{\mathrm{E}}$. Commerce Street occupied by Mrs. Mina Fox. Apparently, from about 1910 until about 1925, the downstairs portion of the building, $301 \mathrm{E}$. Commerce Street, was used by numerous commercial establishments while the upstairs portion, 3011/2 E. Commerce Street, was reconverted into a residence/ apartment. At this time, Rollins was now advertising general repairs, specializing in lawn mowers, gas, and stoves.

By 1912 the business structure remained the Dixie Loan Company, but Rollins was replaced by L. A. Howard's Barber Shop. The rental was occupied by
Mrs. Lillian Frazier, widow of James Frazier. The following year, the business portion of the structure housed only the Dixie Loan Company, but now managed by Rudolph Olfers. In 1914, the commercial portion of the structure was shared by the newly named Dixie Company and the San Antonio Shoe Hospital. That same year, Mrs. Frazier remarried and was sharing the quarters with her new husband, C. L. Goodman. The Dixie Company and the Shoe Hospital remained at the site until at least 1918; it is unclear who occupied the structure-the commercial or residential portions-for the next several years, however.

In 1925, a new owner, J. D. Oppenheimer, sold a 16.65 $\mathrm{x}-118.4$-ft portion of the site for $\$ 1,600$ to the city so that Bonham Street could be widened. As a result, the lot was radically altered: the two-story structure was 
shortened by $16 \mathrm{ft}$ (BCDR 811:295) and the remainder was remodeled into several small shops. Additional shops were also built on the site between the primary structure and the back of the lot line (Figure 9-1). The property continued to house various retail shops-including a barbershop (Smitty's from 1934 until 1943), a café (the Eat-a-Bite in 1939), and a tailor shop (London Tailors from 1946 until ca. 1951) - until the site was finally razed between 1951 and 1957.

\section{Archaeological Investigations}

CAR archaeologists investigated 41BX635 in January and February 1985. A privy (Unit 3), two handexcavated units, and a mechanical trench (Trench A) were excavated.

Since the southern two-thirds of the site was totally disturbed during the demolition of the buildings and concrete slabs and foundations, our work concentrated on the northern section. The first testing on the Faska site was focused at the intersection between Lots 1 and 2 in a search for traces of the acequia that we anticipated might still be visible along the north boundary of the lots. Units $1(2-\mathrm{x}-4 \mathrm{ft})$ and $2(3-\mathrm{x}-4 \mathrm{ft})$ revealed no evidence of the acequia, but various confusing stone walls were present. One of these walls turned out to be the east wall of a stone-lined privy, inside measurement ca. 4 x $6 \mathrm{ft}$, designated Unit 3 .

\section{Privy Excavation}

When Unit 3 was opened, it was readily apparent from the dense artifact content, the dark color of the soil, and the shape and size of the stone-walled enclosure that this feature was entirely different from others. Excavation of this unit was done immediately, during the testing phase, because of the necessity to complete examination of Block 1010 in one operation due to the construction schedule.

The excavation of Unit 3 was constricted by the presence near the top of the footing of a poured concrete foundation which sat on top of the original north and east stone walls of the privy and projected about a foot over the privy contents (Figure 9-2). However, the archaeologists worked carefully around this impediment, removing the entire contents of the privy to sterile soil at the bottom. An iron sewer pipe was found to project through the south privy wall into the feature. Unit 3 was excavated according to stratigraphic fill levels as indicated by differences in soil matrix. Five levels were identified.

\section{Artifacts}

Table 9-1 presents the artifacts recovered from 41BX635 by horizontal and vertical units. The privy contained 94.66 percent of all artifacts recovered from the site. These artifacts are described below.

\section{Ceramics}

One hundred seventy-four undecorated whiteware sherds and 41 various decorated ware fragments were recovered from the feature (Table 9-2). The reconstructed undecorated whitewares, including isolated diagnostic fragments, reveal an almost even distribution between tablewares and utilitarian vessels. A complete small bowl, two saucers, a deep-welled dish, two chamberpots (one with its lid), and another chamberpot lid were recovered. Although there were few decorated wares, there was much typological variability among those present (Figure 9-3). A flow blue with gold overlay bowl and an overglazed floralmotif chamberpot lid were the only decorated vessels that could be partially reconstructed. Twenty stoneware sherds were identified. Most were salt glazed with an Albany-slip interior. These appear to have been either jugs or crocks. Seven of the stoneware fragments had an interior glaze that suggests that they may have been from a baking dish (Lehner 1988:105). Twenty porcelain sherds were also recovered. Vessel form, however, is unknown.

Many of the ceramics were dateable. Four maker's marks from Level 12 were identified, including two ca. 1890 ironstone fragments marked "Ironstone China/ J. G. MEAKIN,/HANLEY,/ENGLAND"; an ironstone condiment dish produced by $\mathrm{H}$. Burgess sometime between 1864 and 1892; and a fragment 


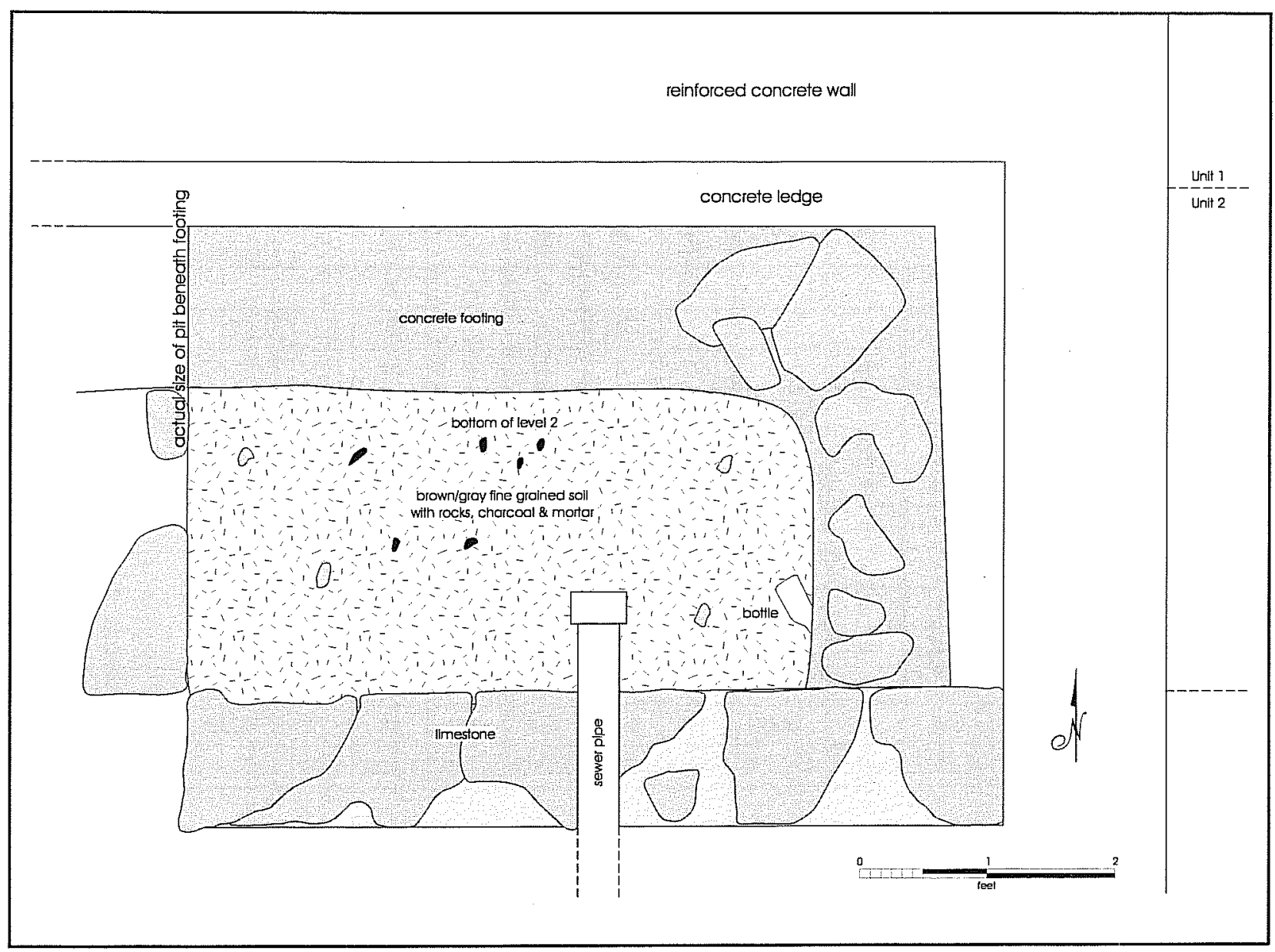

Figure 9-2. Plan of the Faska privy at the bottom of Level 2.

marked "J. H. BAUM," who was an American producer until 1897 (Godden 1964:116, 427; Barber 1967:128). An ironstone chamberpot from Level 10 was produced by "JOHNSON BROS." sometime between ca. 1883 and the present (Godden 1971:73). It is also interesting to note that sherds from a chamberpot marked "BAKER AND CO." were crossmended from levels 10 and 11 . The maker's mark has not been identified, but this may serve as evidence that the two levels are temporally contemporaneous.

\section{Bottle glass}

Seven hundred ninety-seven fragments of glass were recovered from the feature. Fortunately, the glass assemblage included about 67 complete, or mostly complete, bottles. Diagnostic fragments that could reveal content were also examined. The bottles and diagnostic fragments provided excellent chronological data, but more importantly, they also supplied many insights into the daily lives of San Antonians living at, or near, the turn of the century.

Momentarily avoiding theories about bottle re-use and the consequent depositional lag time, the inhabitants of 41BX635 would appear to have suffered from ill health. Forty-six of the identifiable bottles contained a medicinal product intended to relieve a wide variety of symptoms: skin irritations, liver problems, upset stomach, fatigue, congestion, and chronic headaches. Also included in this category was a small number of more benign products such as Listerine, BromoSeltzer, and Vaseline. Medicinal bottle re-use would, in fact, seem to validate the argument for the suggested poor health of the site's residents: many of the bottles were relatively small with extremely restricted necks and would, therefore, appear to have been inappropriate for anything other than medicine. 
Table 9-1. Artifacts from the Faska Site

\begin{tabular}{|c|c|c|c|c|c|c|c|c|c|c|c|c|c|}
\hline Provenience & 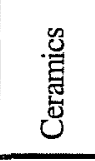 & $\begin{array}{l}\text { 总 } \\
\text { J }\end{array}$ & 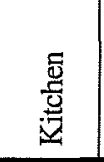 & 芦 & 兽 & 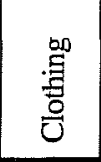 & 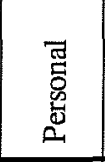 & 冚 & 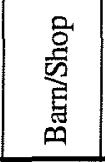 & 首 & 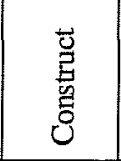 & $\stackrel{\stackrel{\mathscr{U}}{:}}{:}$ & \\
\hline Unit 1, Lv. 1 & 0 & 0 & 0 & 0 & 0 & 0 & 0 & 0 & 0 & 0 & 0 & 0 & 0 \\
\hline Unit 1, Lv. 2 & 0 & 0 & 0 & 0 & 0 & 0 & 0 & 0 & 0 & 0 & 0 & 0 & $\mathbf{0}$ \\
\hline Unit 1, Lv. 3 & 0 & 0 & 0 & 3 & 2 & 0 & 0 & 0 & 0 & 0 & 4 & 0 & 9 \\
\hline Unit 2, Lv. 1 & 7 & 24 & 0 & 3 & 0 & 1 & 1 & 0 & 0 & 0 & 16 & 0 & 52 \\
\hline Unit 2, Lv. 2 & 22 & 45 & 0 & 61 & 0 & 1 & 0 & 1 & 0 & 0 & 41 & 1 & 172 \\
\hline Unit 2, Lv. 3 & 9 & 22 & 0 & 0 & 3 & 1 & 0 & 0 & 0 & 0 & 34 & 2 & 71 \\
\hline Unit 3, Lv. 1 & 0 & 0 & 0 & 0 & 0 & 0 & 0 & 0 & 0 & 0 & 0 & 0 & o \\
\hline Unit 3, Lv. 2 & 135 & 391 & 4 & 618 & 43 & 48 & 4 & 2 & 15 & 1 & 2073 & 7 & 3341 \\
\hline Unit 3, Lv. 3 & 25 & 24 & 0 & 155 & 1 & 75 & 2 & 2 & 1 & 1 & 50 & 1 & 337 \\
\hline Unit 3, Lv. 4 & 95 & 382 & 0 & 845 & 10 & 35 & 204 & 11 & 2 & 0 & 135 & 0 & 1719 \\
\hline Unit 3, Lv. 5 & 0 & 0 & 0 & 0 & 0 & 0 & 0 & 0 & 0 & 0 & 0 & 0 & 0 \\
\hline Total & 293 & 888 & 4 & 1685 & 59 & 161 & 211 & 16 & 18 & 2 & 2353 & 11 & 5701 \\
\hline \% of Total & $5.14 \%$ & $15.58 \%$ & $0.07 \%$ & $29.56 \%$ & $1.03 \%$ & $2.82 \%$ & $3.70 \%$ & $0.28 \%$ & $0.32 \%$ & $0.04 \%$ & $41.27 \%$ & $0.19 \%$ & \\
\hline
\end{tabular}

The other complete bottles once contained, in descending order of frequency, alcohol, foods or condiments, tobacco (snuff), and milk. The majority of the intact or reconstructed alcohol bottles contained either whiskey or a similar hard liquor. Only one wine bottle and a few beer bottle fragments, in fact, were recovered from the privy. It is tempting to offer an interpretation that attempts to correlate the presumed poor health of the residents to the frequency of liquor bottles, but this would require taking too many liberties with data.
Two medicine bottles from Level 12 were marked "KALTEYER \& SCHUCHARD/E. HOUSTON ST./ SAN ANTONIO, TEX.". Evidence suggests that the aforementioned pharmacists joined operations for only a short while from 1892 to 1893 (City Directory 1892:389). Two other medicinal bottles of local origin from the same level were marked with "A. NETTE/ APOTHECARY/ SAN ANTONIO. TEX.". Auguste Nette Jr. and Sr., were first in business from 1877 to 1878 and then again from 1881 until 1891.

Table 9-2. Ceramic Types from the Faska Privy

\begin{tabular}{|c|c|c|c|c|c|c|c|}
\hline Level & lead glazed & dec. ww. & undec. ww. & porcelain & stone ware & plain colored & Total \\
\hline 1 & 0 & 2 & 12 & 1 & 0 & 1 & 17 \\
\hline 2 & 2 & 6 & 82 & 8 & 19 & 0 & 119 \\
\hline 3 & 0 & 0 & 20 & 4 & 1 & 0 & 28 \\
\hline 4 & 0 & 28 & 60 & 7 & 0 & 0 & 99 \\
\hline total & 2 & 36 & 174 & 20 & 20 & 1 & 253 \\
\hline$\%$ of total & $0.79 \%$ & $14.23 \%$ & $68.77 \%$ & $7.91 \%$ & $7.91 \%$ & $0.40 \%$ & \\
\hline
\end{tabular}


Two bottles from Level 11 are believed to have been produced sometime between 1890 and 1900. The bottles were produced for Dr. J. J. Tobin, an Austin druggist, and are marked with "PAT D. MAY 1588 / D.F. \& CO." on the bottom. D.F. \& Co. has not been identified, but there is evidence that the company was manufacturing prescription bottles with the same markings for druggists as far away as California during this time (Toulouse 1971:160). Another small medicine bottle produced by the Whitehall-Tatum Co. of Millville, New Jersey, between ca. 1857 and 1938 was also recovered form Level 11.

A condiment bottle produced by the Illinois Glass Company between 1916 and 1929 was excavated from Level 10 (Toulouse 1971:364). And a "LISTERINE/ LAMBERT PHARMACAL COMPANY” bottle manufactured between 1894 and 1915 was also recovered (Toulouse 1971:373-374).

Level 9 did not include any positively dateable bottles or glass fragments. There was, however, a partial alcohol bottle marked with ". . . LT WHISKEY COM ..." on the side and "PATD AUG 241886 " on the bottom. The bottle has been identified as being from the Duffey Malt Whiskey Company of Rochester, New York, but the patent date does not necessarily reflect the year of production (Adams 1971:113).

\section{Personal and Household Items}

A wide variety of personal and household items were found in all levels of the privy. A number of hygienic items, including the previously mentioned mouthwash bottles, two bone toothbrush handles, 201 fragments of a douche, and two combs-one metal from Level 12 and one hard rubber from Level 10-were excavated.

Three coins were excavated from Level 12. They include an 1898 Liberty Head nickel, an 1867 Shield nickel, and a 1883 half dollar with a seated female liberty holding a flag and a shield depicted on the obverse (Yeoman 1967:92-923, 133).

There were also many clothing remains. Thirty-one buttons of various compositions were excavated.
Seventeen shell buttons were found in Level 10. These buttons have been manufactured since the 1850 s, but it is believed that they reached the zenith of their popularity in about 1900 (Pool 1982:269). Eleven metal buttons were recovered from Levels 11 and 10 . Most appear to be post- 1870 trouser buttons; a more specific date cannot be established, however, as metal remains a popular button material (Pool 1982:269). Similarly, two brass collar buttons and a single machine and handmade ceramic button were identified from Level 12. Eighty-nine shoe fragments including 65 leather fragments, ten shoelace eyelets, a few rubber heel fragments, and ten segments of cloth shoelace were located. Such a large a quantity of shoe material might suggest that its deposition was associated with the Shoe Hospital that was located at the site from 1914 until 1918 (CDs 1914-1917). Finally, a blue glass heart and four associated beads from Level 10 probably came from a single necklace.

\section{Kitchen and Food Items}

A multiplicity of artifacts associated with eating were excavated from the privy. Food items were well represented by 1618 bones, 4 egg shell fragments, and one peach pit. It is interesting that a number of condiment bottles and one condiment dish were recovered. The previously mentioned ceramic assemblage contained a wide variety of vessels associated with the preparation and serving of food. A fork, knife, and spoon were also identified. Four drinking glasses, in addition to two coffee cups, were located.

\section{Toys}

Children were present at the site as evidenced by a handmade, German-produced glass marble from Level 12 and two stone and one clay marble all from Level 10. The glass marble and the stone marbles were produced sometime before 1920 (Carskadden and Gartley 1990:67). Seven doll fragments were also excavated. Two bisque pieces from Level 12 were marked with ". . . 1288 Germany N7" and have tentatively been identified according to the mold number as a product of the Alt, Beck, \& Gottschalk 
Company, and made sometime between 1854 and the late 1940s (Bach 1985:3). Two other fragments, presumably from the same doll, were crossmended from sherds from Levels 12 and 11. A poorly made, inexpensive China limb doll leg and an unidentifiable fragment were recovered from Provenience 10 . We are unable, however, to link the toys to specific families or children since only large time frames for the artifacts could be established.

\section{Construction}

The largest numerical category of artifacts excavated from the privy was the construction class. It was almost entirely comprised of window glass fragments and cut and wire nails. The largest amounts of each -742 glass fragments and 1125 nails - were excavated form Level 10. Three tile fragments and three mortar samples were recovered from Level 11 . Evidence of gas and electrical utilities appeared only in the upper levels. Light bulb fragments likewise were also found in the upper proveniences. The appearance of artifacts associated with electrical lighting may serve as a tangible indication of the introduction of electricity. Electrical lighting was common in most homes in the city by the early twentieth century. Similarly, twentyone lamp parts, exclusively limited to chimney glass from either candle or gas lamps, were excavated from Levels 9 and 10 Their presence, however, is of dubious chronological significance: candles have been used until the present as ornamental house furnishings and alternative lighting sources.

\section{Discussion}

An examination of the stratigraphic fill levels and the corresponding artifact dates suggest that the privy was gradually filled sometime between about 1897-1904 and 1920. The earliest known date from Level 12 was 1860 while the latest was from 1910 . A majority of the identifiable artifacts appear to have been manufactured from about the late 1870 s to the 1880 s. The earliest possible date from Level 11 was 1840 and the latest date was 1910. Most of the artifacts seem to date between 1890 and 1900 . There were, however, large amounts of shoe parts which may have been associated with the ca. 1914 Shoe Hospital. There was also some evidence of burning in Level 11. The ash lens was thin and amorphous, however, and the artifacts do not appear to have been exposed to fire. It would, therefore, be impetuous to assume that after the initial deposit in Level 12 , the privy was used as a refuse incinerator. The earliest known date from Level 10 was 1874 and the latest from 1929. Most of the artifacts suggest manufacture between the 1890s and 1910.

It can be assumed from the variety of bottle originsNew York state, Philadelphia, St. Louis, and Mexico, for example-that most of the bottles post-date the introduction of the railroad in 1878. Many of the bottles, and especially those from local druggists, could be given fairly precise dates of manufacture. For the sake of brevity, a minimal number of these bottles and their dates are listed to aid in establishing a gross chronological range for each of the levels.

It is interesting to note that the privy may have been used for specific types of artifacts that the residents would have perceived as being hazardous-glass, nails, and unused medicines, for example.

Conclusions about the privy's fill may tempered by the acknowledgment that there were some disturbances and intrusions. The three coins from Level 12, for instance, seem incongruous with the Bakelite (post1908) douche applicator in the same level. Also a newspaper fragment found in Level 10 most certainly is a product of the ca. 1960 s concrete parking lot.

The privy reflects ideological changes occurring across the city concerning the disposal of human waste. There was an increased interest in health, especially in epidemiology, throughout the 1880 s and 1890s. The relationship between sanitation and health was becoming better understood. As a result, the San Antonio City Council produced a good deal of legislation that directed the transition from outdoor privies to indoor sewerage.

Beginning in the early-1800s, and continuing until after the turn of the century, the city created progressively more restrictive ordinances regulating 
the construction and maintenance of privy vaults (City Ordinances [CO], Office of City Secretary, City Hall, San Antonio, Book A-44, October 3, 1882:69; Book A-119, February 3, 1884:184; Book A-40, April 18, 1884:64; Book A-159, October 24, 1889:253). Simultaneously, a health board, complete with sanitation inspectors, was created to enforce the new laws (CO Book A-56, September 4, 1883:81; Book A-61, December 18, 1883:94).

A bond was passed in 1894 for constructing the municipal sewer system (CO Book B-120, September $24,1894: 199)$. And by 1901, an ordinance was passed which prohibited persons from digging privy vaults in areas where sewers had been constructed (CO Book C-329, October 14, 1901:280). Archival research indicates the residents of 41BX635 probably had access to the sewer system as early as about 1897 . The expense of constructing a bathroom and the unfamiliarity with the new technology, however, may have prevented widespread adoption in the area for another six or seven years.
In contrast to the residential sites on Crockett and Blum Streets which were owned and occupied throughout their existence by single families, the Vanderstratten and Faska sites were typical of the commercial occupations that developed on the main thoroughfares such as Bonham and Commerce. It is not surprising to find residential occupation of the second floor of the Faska building, since it was quite acceptable to live "over the store" in the mid- to late nineteenth century, sometimes by the proprietor's family and sometimes at a later time by families looking for an inexpensive place to live near the place of employment of the wage earner.

The contents of the privies on these lots appear to represent mainly the discards of the residential occupants, despite the probable use of the privy by shop proprietors as well. The presence of so much demolition debris in the top levels of this privy, along with the comparatively late date of the artifacts, suggests that it was abandoned and filled before or at the time of the 1825 remodeling. 


\section{Chapter 10: The Battaglia Site}

Site Identification: The Battaglia Site, NCB 1010, Lot 2

Address: 303 East Commerce

Trinomial: 41 BX641

\section{Historical Background}

Archival records indicate that the site had multiple construction episodes and multiple occupations. The lot was continuously occupied after it was purchased from John and Anita Withers by Gotlieb Schutz on January 3, 1866, for \$500 (BCDR T2:373). Schutz most likely constructed a one-story dwelling that appears on the 1873 Koch map. In April 1873, Schutz sold the property "with improvements" to Maria Kurka (BCDR X1:294. Shortly thereafter, in 1875, the lot was purchased by Julie Eve Richter (BCDR 1:383). Richter in turn conveyed the property to Angelo Battaglia in 1889 (BCDR 73:14). Until this time, the building appears to have been used as a residence, but Battaglia converted the structure into a commercial space for his fruit and vegetable business. It is unclear where Battaglia lived at this time. By 1894, Battaglia constructed a two-story brick structure in front of the original building, on the street line. There is a record that after 1896 Battaglia resided in the upper portion of this brick structure (CD 1896). The "adobe" building was retained and used as a warehouse. Battaglia operated his produce business at the site until his death, when it passed to his wife, Fortuna Battaglia (BCDR 304:240).

Throughout the early twentieth century, the brick building was used as a mixed residential and commercial unit. The first floor housed N. Schnitzer's Dry Goods Store from ca. 1903 to 1914 . At the same time, a widow, Mrs. J. Denson lived above the store. The original adobe dwelling was apparently vacant for much of this time, but there is a record that $T$. and Cecelia Salazar lived in the building in 1912. In 1917, L. and Edith Ellis occupied the adobe building and operated a restaurant (Edith's Rest) in the lower floor of the brick building while the upstairs housed the Bexar County Club.
Thereafter, for about 10 years (ca. 1918 to 1927), only Everybody's Cafe is recorded as occupying the site. In ca. 1928 the Alamo Employment Company and the Hagner Tire Company shared the remaining building. The adobe structure had been razed in 1925. Five different restaurants operated in the brick building from about 1934 until 1951, including the Fast Nickel Cafe (1934-35), Smith's Five Cent Eats (1936-37), Acme Five Cents Eats (1938-42), Melvin's Cafe (1942-43), and Martinez Cafe (1946-51).

\section{Archaeological Investigations}

CAR archaeologists investigated the Battaglia Site in March 1985. Three hand-excavated units, including a privy pit, were completed. Most of the artifacts appear to have been deposited in the late nineteenth or early twentieth centuries.

\section{Unit 2A -Test Trench}

Unit 2A was contained within the backhoe-cleared area at the back of the lot, and consisted of the first three feet of the 15 foot swath cleared at the west lot line (Figure 10-1). Unit 2A was excavated to sterile soil at a depth 15 inches below the surface. The contents were screened, and there was no observable stratigraphy.

Decorated and undecorated whitewares were retrieved from this unit, as well as one sherd of Goliad ware (Table 10-1). A few pieces of whiteware were partially reconstructed but did not produce any whole or nearwhole items. None of the reconstructions matched fragments from adjacent units, but one piece from Unit A matched a piece from Unit $C$. 


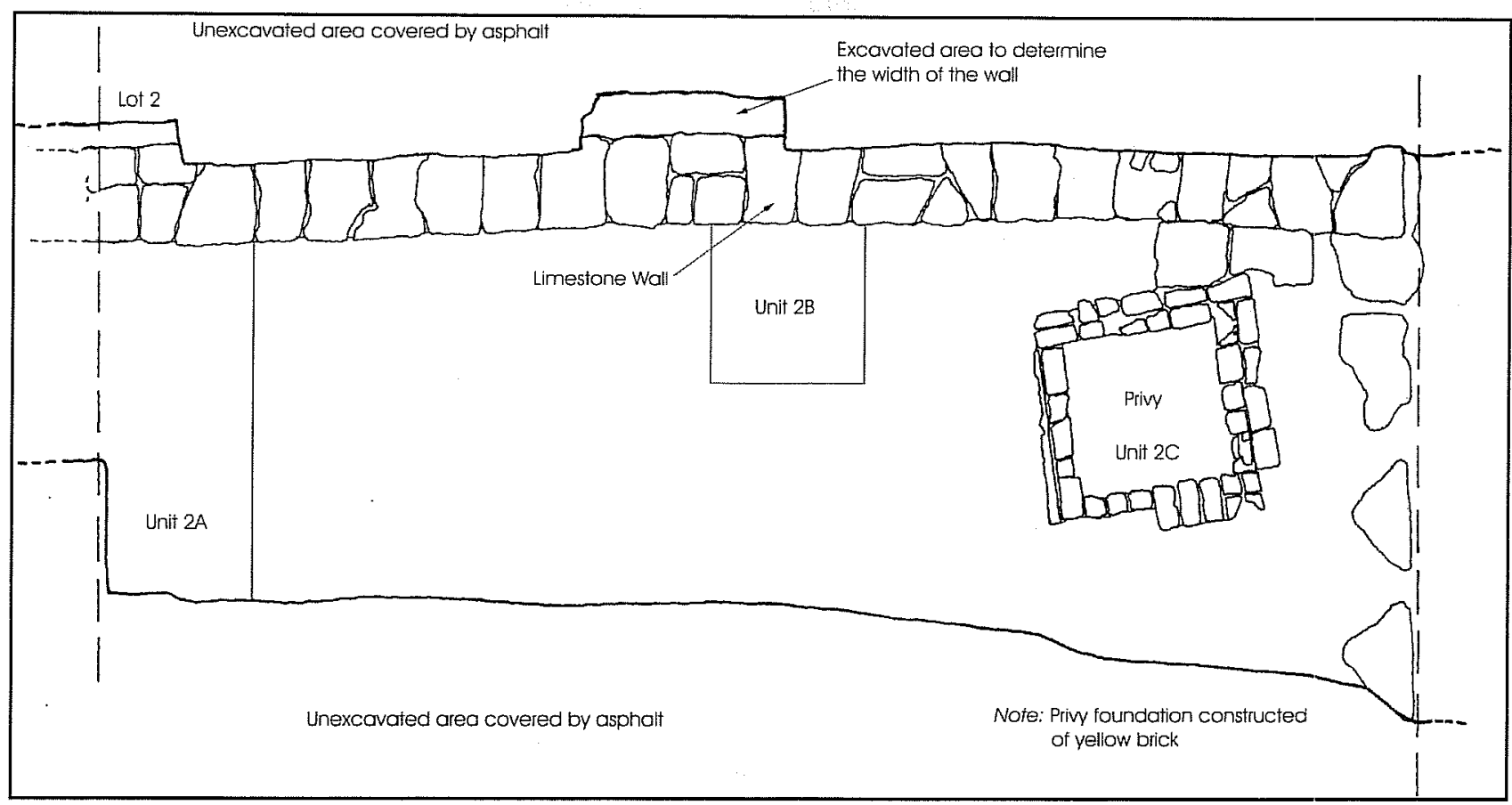

Figure 10-1. Plan of the back fifteen feet of the Battaglia lot.

Various colored glass fragments were retrieved, including a green kick-up bottle base 3 inches in diameter which could possibly be dated between 1840 and 1870. A 3-3/4 inch high clear glass bottle with a small neck and a small hole in the top for dispensing liquid, possibly hot sauce, was found in Unit A. A 6 inch bottle embossed on the bottom can be dated to a post1900 period because of continuous mold seams (Kendrick 1966:48). Eight clear glass fragments with a raised pattern of diagonal ridges and embossed lettering appears to be a twentieth-century soda water bottle.

One brass $15 \mathrm{~mm}$ military button with a gilt finish can be identified and dated. According to Albert and Kent (1949:356, Figure 23), the button is a U. S. General Services button from a cuff, vest, or jacket that was in use in 1902 and later. The Waterbury Button Company of Connecticut manufactured the button and used the same type of makers mark until 1944 (Albert and Kent 1949:402).

\section{Unit 2B - Test Unit}

Unit 2B was a 1-x-1-m test unit, farther to the east in Lot 2 . It was excavated to sterile soil at approximately
15 inches. Recovered were eight fragments of a large unglazed crock or plant container (Table 10-1). Partial reconstruction of 13 pieces of aqua glass revealed the container was embossed "THE CUTICURA SYSTEM OF CURING CONSTITUTIONAL HUMORS." It was manufactured by the Potter Drug and Chemical Corporation of Boston, Massachusetts. The bottle was a square corker, nine inches high, in use from 1882 to 1892 (Wilson 1981:137).

\section{Unit 2C - Privy Pit}

Unit 2C was a brick-lined privy pit, $2 \mathrm{ft} 8$ inches by 3 $\mathrm{ft} 8$ inches (interior measurements) and $4 \mathrm{ft}$ six inches deep, excavated according to natural stratigraphy.

Only one of the undecorated ware sherds had a maker's mark, in this case a partial mark, ". . . INA", which was not sufficient to identify the manufacturer. According to Godden (1964:729) many manufacturers used "Real Stone China" or "Real Ironstone China" on ironstone made after 1820 , but nothing more specific could be determined. Additional undecorated whiteware fragments were recovered in this unit, but none could be cross-mended with those of other units in Lot 2 (Table 10-1). 
A number of sherds of decorated whiteware were partially reconstructed into a small bowl or cup. A blue and white floral and checked pattern on the exterior and interior of the pieces could not be identified or dated. However, the pattern resembles those popular in the early 1900s. The sherds were found in all levels of the excavation. Very little porcelain was found on Lot 2, but one fragment from Unit $\mathrm{C}$ appears to have an Oriental pattern on the exterior surface.

Several milk glass fragments from Level 1 of this unit were reconstructed into a Vaseline jar. Made by the Cheeseborough Manufacturing Company, this would have been in use from about 1870 to 1890 (Wilson 1981:59).

A whole rectangular aqua patent medicine bottle 6-1/ 4 inches high came from Level 2. Embossed on the surface was "HAMLIN'S WIZARD OIL" and it was bottled in Chicago. Based on the length of the mold seams, the bottle was manufactured between 1880 and 1890.
Two Lea \& Perrins eight-ounce light green bottle bases were recovered (Wilson 1981:84, Figure 294). One base from Level 1 had "J $80 \mathrm{D}, \mathrm{S}$ " on the bottom, and on one from Level 4, "J 40 D,3". These were bottled by John Duncan \& Sons of New York between 1900 and 1920. Duncan was the first licensee for the importation of Lea \& Perrins pepper sauce into the United States (Toulouse 1971). Additional dating could be determined by the identification of aqua fragments of a cathedral/Gothic-style pepper sauce bottle. Wilson (1981:88) dates this type of bottle between 1850 and 1890. Whiskey and shoe-blacking bottles were also represented in the privy deposit.

An important household item for dating purposes is a light socket from a drop ceiling fixture. The socket, with wires protruding from one end and a portion of a light bulb base in the other, can be dated to the turn of the century, since the wiring is surrounded by remnants of its original rubber insulation.

Table 10-1. Artifacts from the Battaglia Lot

\begin{tabular}{|c|c|c|c|c|c|c|c|c|c|c|c|c|}
\hline Unit/Level & 总 & 兽 & 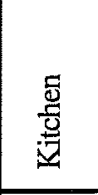 & 造 & 鸹 & 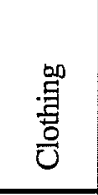 & $\begin{array}{l}\overline{\mathbb{Z}} \\
\overline{\tilde{0}} \\
\bar{d} \\
0\end{array}$ & 总 & 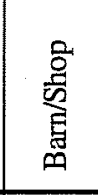 & 䙷 & 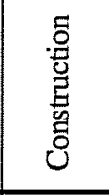 & Total \\
\hline Unit A & 60 & 201 & 0 & 561 & 14 & 14 & 2 & 3 & 1 & 0 & 225 & 1081 \\
\hline Unit B & 3 & 20 & 0 & 4 & 14 & 0 & 0 & 0 & 0 & 0 & 2 & 43 \\
\hline Unit C, Surf. & 0 & 0 & 0 & 0 & 0 & 0 & 1 & 0 & 0 & 1 & 1 & 3 \\
\hline Unit C, Lv. 1 & 7 & 34 & 0 & 64 & 3 & 4 & 0 & 7 & 0 & 0 & 93 & 212 \\
\hline Unit C, Lv. 2 & 10 & 30 & 0 & 64 & 1 & 1 & 2 & 2 & 1 & 1 & 35 & 147 \\
\hline Unit C, Lv. 3 & 2 & 4 & 0 & 22 & 0 & 2 & 0 & 1 & 0 & 0 & 69 & 100 \\
\hline Unit C, Lv. 4 & 1 & 0 & 0 & 9 & 0 & 0 & 0 & 0 & 0 & 0 & 32 & 42 \\
\hline Unit C, Lv. 5 & 1 & 3 & 0 & 148 & 0 & 2 & 1 & 0 & 0 & 2 & 34 & 191 \\
\hline Unit C, Lv. 6 & 2 & 0 & 0 & 58 & 0 & 1 & 0 & 0 & 0 & 20 & 34 & 115 \\
\hline Unit C, Lv.7 & 1 & 5 & 0 & 0 & 0 & 0 & 0 & 0 & 0 & 0 & 18 & 24 \\
\hline SE Corner & 10 & 7 & 0 & 0 & 1 & 0 & 0 & 1 & 0 & 0 & 4 & 23 \\
\hline Backdirt & 21 & 17 & 0 & 0 & 1 & 1 & 1 & 1 & 1 & 0 & 1 & 44 \\
\hline Backhoe Cut & 33 & 54 & 0 & 31 & 0 & 0 & 0 & 0 & 1 & 0 & 48 & 167 \\
\hline Totals & 151 & 375 & 0 & 961 & 34 & 25 & 7 & 15 & 4 & 24 & 596 & 2192 \\
\hline$\%$ of Total & $6.89 \%$ & $17.11 \%$ & $0.00 \%$ & $43.84 \%$ & $1.55 \%$ & $1.14 \%$ & $0.32 \%$ & $0.68 \%$ & $0.18 \%$ & $1.09 \%$ & $26.92 \%$ & \\
\hline
\end{tabular}




\section{Discussion}

Deposition of debris on Lot 2 was apparently from an average San Antonio household around the turn of the century. Buttons, pins, needles, a small brush handle would all have been lost, swept into the trash, and discarded. The presence of children is reflected in two marbles, part of a toy car, part of a porcelain doll dish, and several slate pencils and fragments of slate. Various metal items, window glass scrap metal, wire, and nails are items found around most houses. The evidence is consistent with the history of a residence near the back of the lot, in this general location, during that time period.

The artifacts recovered from the back portion of this lot (Table 10-1) reflect the residential uses of the buildings as well as the frequent construction and remodeling that went on there. Here again, as at the Faska Site, we find residential and commercial occupations going on at the same time, and families living over the store. 


\section{Chapter 11: The Kissling Site}

Site Identification: The Kissling Site, NCB 1010, Lots 3 and 4

Address: 305 East Commerce

Trinomial: $41 B \times 642$

\section{Historical Background}

John (Johann Joseph) Kissling purchased these lots, along with lots 5 and 6 , for $\$ 500$ per lot from the Withers on 13 November 1866 (BCDR U2:325). Kissling, a stone mason, was born at Hessencassel, Germany in 1830 , and by 1850 had migrated to Texas (U.S. Census 1850). He declared for naturalization on May 26, 1853 (naturalization records), and married Agnes Reinhart on May 31, 1856 (San Fernando Church Records).

Since Kissling was a builder, he probably constructed the "adobe" house with basement at about this time. It appears on the 1873 and 1886 Bird'seye Maps as well as the 1904 Sanborn map. He apparently occupied it as a residence with his wife and their seven children until 1879, when Agnes “deserted" him (BCDR 185:319). Agnes moved to Brackett, never to remarry, and died in 1904 (BCDR 258:586). Kissling continued to reside in the house until 1884, when he moved to 121 Peach Street where he lived until his death in 1917.

In January 1900 Kissling conveyed the property (lots 3 and 4) to J. W. Campbell for $\$ 5000$. Soon afterward, a second story was added to the house, or possibly it was rebuilt, for in 1904 there are rentals upstairs (CDs 1903-1914). It continued as a commercial establishment (a furniture store, a plumbing establishment, a barber shop, a repair shop) until it was razed between 1951 and 1957 (CDs 1914-1957).

\section{Archaeological Investigations}

Lots 3 and 4 of NCB 1010 were excavated separately, one unit randomly located in the approximate center of each lot. Lot 4 contained a trash deposit. Both excavations were initiated at 18 inches below the original surface of the lot. In assigning site numbers, Lots 3 and 4 were combined as 41BX642, since they were purchased and developed as one lot.

\section{Unit 3A}

Unit 3A was a one-meter square test pit excavated in two 10 centimeter levels. Most of the artifacts recovered from this unit were from Level 1 (Table 111). They included small fragments of porcelain and undecorated whiteware.

Various colored glass fragments were recovered, but nothing was diagnostic. There was a small amount of window glass present. Other items included two slate pencil fragments, a 3/4-inch square green ceramic tile, scrap metal, mortar, and cut nails.

\section{Lot 4, Unit A}

Unit 4A as a one-meter square test pit located in the vicinity of an outbuilding shown on the 1904 Sanborn Insurance Map. As was noted for Unit 3A, most of the artifacts were recovered from Level 1 (Table 111). Some of the items included a portion of what may have been a cameo brooch or locket featuring the upper torso and neck of a woman. One small porcelain fragment with black paint on one face appears to be part of a small figurine or doll's head. Although these items are intriguing, they could not be dated. Two of the five ironstone fragments from Level 1 were reconstructed to form a minimal amount of a maker's mark, "R. . .J. ..." along with part of a crown. These have been identified as royal semi-porcelain from John Maddock \& Sons, England. This piece was manufactured about 1906 or later. 
Various fragments of colored glass were excavated from this unit. One aqua fragment with the lettering "RSPA" is probably part of a sarsaparilla bottle, but is not datable. Buttons, a buckle, a metal fastener, window glass, scrap metal, cut nails, and wire were also collected from the excavation of Unit 4A.

Part of a whiteware chamberpot was partially reconstructed by cross-mending five fragments from Level 1 of Unit 3A and 2 fragments from Level 1 of Unit 4A.

A large number of artifacts were also collected during backhoe excavations and wall cleaning on Lots 3 and 4 (Table 11-1). These have no particular provenience, but are of interest in the interpretation of these lots. Approximate dates can be assigned to several items:

1872-1900: Ironstone fragment from Knowles, Taylor \& Knowles, Ohio (Ramsay 1976:216) 1880-1900: Clear glass bottle 5 7/8-inches high
1902+: $23 \mathrm{~mm}$ overcoat or uniform coat military button, brass with gilt, Waterbury Button Company, Conn. (Same design as the one found in Lot 2 Unit A.

1880-1900: Clear stoppered round bottle 3 inches high

1900+: Aqua panel bottle labeled "CASTORIA"

1900+: Green diamond-shaped bottle, 3 inches high, labeled "JES PAT/92/49"

\section{Discussion}

If Kissling, his wife, and seven children resided at 305 East Commerce, the amount and type of trash recovered is hardly representative of their occupation. After 1900 the structure was either enlarged or replaced. Certainly many of the artifacts found during excavation were deposited on Lots 3 and 4 for many years after the turn of the century. The dates for artifacts from Lots 3 and 4 are very close to the same time period established for 41BX641 (the Battaglia site) on Lot 2 of NCB 1010.

Table 11-1. Artifacts from the Kissling Site

\begin{tabular}{|c|c|c|c|c|c|c|c|c|c|c|c|c|}
\hline Unit/Level & 兽 & $\begin{array}{c}\mathscr{8} \\
\text { 营 }\end{array}$ & $\begin{array}{l}\text { 胥 } \\
\text { 运 }\end{array}$ & . & 异䍖 & $\begin{array}{l}\text { 目 } \\
\text { 总 }\end{array}$ & 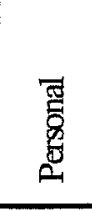 & 总 & $\begin{array}{l}\text { 总 } \\
\text { 总 } \\
\text { 总 }\end{array}$ & 量 & 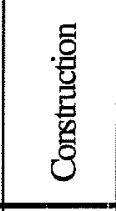 & Total \\
\hline Unit 3A, Lv. 1 & 42 & 152 & 0 & 146 & 1 & 3 & 0 & 4 & 0 & 0 & 194 & 542 \\
\hline Unit $3 A, L v .2$ & 0 & 6 & 0 & 2 & 0 & 0 & 0 & 0 & 0 & 0 & 4 & 12 \\
\hline Unit $4 A, \operatorname{Lv} 1$ & 36 & 119 & 0 & 408 & 0 & 4 & 1 & 1 & 1 & 0 & 141 & 711 \\
\hline Unit 4A, Lv. 2 & 0 & 2 & 0 & 6 & 0 & 0 & 0 & 1 & 0 & 0 & 9 & 18 \\
\hline Unit 4A, Lv. 3 & 1 & 10 & 0 & 12 & 0 & 0 & 0 & 1 & 0 & 0 & 17 & 41 \\
\hline Unit 4A, Backdirt & 3 & 4 & 0 & 0 & 1 & 0 & 0 & 0 & 0 & 0 & 2 & 10 \\
\hline $\begin{array}{l}\text { Unit 4A, } \\
\text { NorthWall }\end{array}$ & 8 & 17 & 0 & 0 & 3 & 0 & 0 & 0 & 2 & 0 & 10 & 40 \\
\hline $\begin{array}{l}\text { Unit 4A, } \\
\text { Wall Clean }\end{array}$ & 14 & 45 & 0 & 11 & 10 & 1 & 0 & 0 & 0 & 0 & 45 & 126 \\
\hline Backhoe & 21 & 34 & 0 & 9 & 1 & 3 & 1 & 2 & 29 & 1 & 69 & 170 \\
\hline Totals & 125 & 389 & 0 & 594 & 16 & 11 & 2 & 9 & 32 & 1 & 491 & 1670 \\
\hline$\%$ of Total & $7.49 \%$ & $23.29 \%$ & $0.00 \%$ & $35.57 \%$ & $0.96 \%$ & $0.66 \%$ & $0.12 \%$ & $0.54 \%$ & $1.92 \%$ & $0.06 \%$ & $28.14 \%$ & \\
\hline
\end{tabular}




\section{Chapter 12: The Ludlow House and Moody Site}

Site Identification: Ludlow House and Moody Site, NCB 1010, Lots 5, 6, and 7 Address: 307 East Commerce

Trinomial: 41BX643 (Ludlow House)

\section{Historical Background}

Lots 5 and 6 were first acquired, along with Lots 3 and 4, by John Kissling in 1866. In May 1870, Kissling and his wife sold the lots to Edward Steves "for lumber storage facilities" for the Steves Lumber Company (BCDR C4:42).

The 1885 Sanborn Map shows a small adobe house at the back of Lot 5 , but this was gone by the time the 1895 Sanborn Map was made. There was a frame building against the east line of Lot 6 by 1885, which remained for about 20 years, probably to be torn down in preparation for building the Ludlow House.

By 1903, Daniel Ludlow had constructed a three-story brick hotel, the Ludlow House (City Directory 1903), and a long, narrow brick outbuilding across the back of the property on lots 5, 6, and 7 (Figure 12-1). Various uses have been suggested for this building, from stable and later parking garage to wash house, to some sort of business enterprise connected with the hotel. Why it continued onto Lot 7 has not been explained. However, by 1912 it no longer appears on the Sanborn Maps.

In 1912, Mrs. E. Blumenthal had taken over the hotel, which was then called the New Commerce Hotel (City Directory 1912). By 1939, much of the area had become a parking lot (City Directory 1939). The hotel evidently stood empty for a number of years, according to succeeding City Directories. It was torn down sometime after 1952, and by 1961 the Sears Auto Service Center stood on lots 1 to 6 .

Lots 7 and 8 were not sold until 1883. At that time they were purchased from the Withers by Edward
Bennett (BCDR 27:98). They were later conveyed together to S.S. Thomas, who in turn sold them to D. E. Mullen in 1890 (BCDR 66:650), who built a nogged (wood frame structure with brick infill) commercial building on Lot 7. Mullen, in turn, sold both lots to Dr. E.T. Hughes in 1907 (BCDR 114:601), who sold to Dr. G.H. Moody (BCDR 304:587). Lot 7 was occupied by a small wooden cafe from 1903 and 1910 (City Directories 1903 - 1914). This was replaced by a plastered tile commercial building by 1912 (Sanborn Map of 1912). This building continued to occupy Lot 7 until sometime soon after 1952 (Sanborn Map of 1852), when everything on Lots 1 through 7 was razed for the construction of a Sears Auto Service Center (Sanborn Map of 1961).

\section{Archaeological Investigations}

Investigations on these lots included two excavation units intended to recover a sample of artifacts related to the hotel. Two trenches were excavated by hand to examine the interior and construction of the brick outbuilding behind the hotel and to search for indications of prior structures in the area.

\section{Unit 5A -Test Trench}

Unit $5 \mathrm{~A}$ on Lot 5 was a 2-x-15-ft north-south handexcavated trench located within the area cleared along the back lot line of Block 1010 (Figure 12-1). None of the artifacts from this provenience could be securely dated. A post hole found in this unit did not seem to relate to the row of posts later found to run through the center of the brick outbuildong (Table 12-1). 


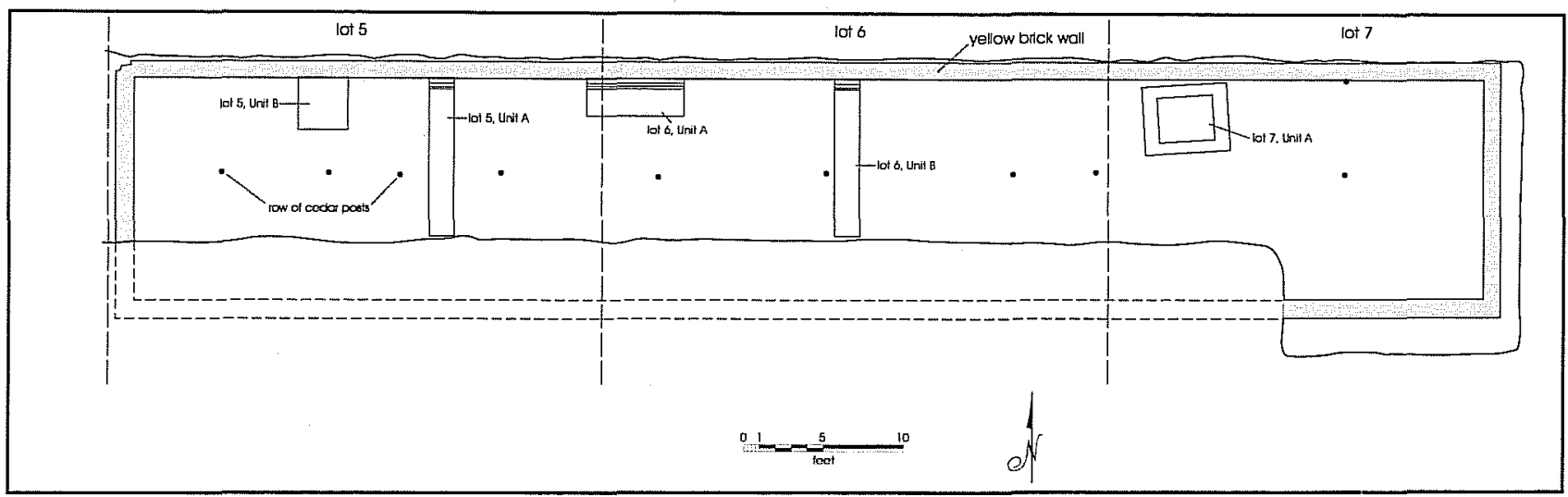

Figure 12-1. Location of the units on the Ludlow site.

Metal scraps, window glass, slate fragments, and door hinges are construction materials recovered from Unit A. A carbon rod and a metal wire cutter are items typical of the workshop area might have been located on the premises. Personal items recovered include buttons, a metal buckle, a marble, and a fragment of a white kaolin pipe.

A typical assortment of glass container fragments include aqua, green, amber, and clear pieces. Household items are more numerous and include fragments from several large stoneware storage crocks, a few sherds of porcelain, decorated whiteware, and two pieces of yellowware.

Undecorated whiteware represents the largest number of household ceramic sherds recovered from Unit $5 \mathrm{~A}$. An ironstone dinner plate was partially reconstructed but did not have a maker's mark. There are also additional small ironstone fragments which do not match the reconstructed plate.

The only cultural material recovered from the post hole includes several cut nails and several fragments of undecorated whiteware.

\section{Unit 5B -Test Unit and Surface Collection}

Unit 5B was a 3-x-3-ft test unit located against the north wall of the outbuilding behind the hotel (Figure 12-1). More artifacts were recovered from Unit 5B than from Unit 5A, and many of these items can be dated (Table 12-1).

Artifacts recovered from Levels 1 to 3 include a 1935 U.S. copper penny, the date of which is obviously not consistent with the earlier dates of the rest of the artifacts from this provenience. Barn/workshop-type materials recovered include scrap metal, window glass, slate and brick fragments, and a harness hook. Personal items are scant but do include one green and one red glass bead, one-half of a heart-shaped metal locket, and a glass perfume bottle.

Household items include a clothes hook, cloth fragments, buttons, and a small metal cap. Porcelain, stoneware, lead-glazed, and burnished ceramic sherds were collected from the first three levels of Unit B. A silver plated spoon manufactured by Rogers Brothers (1847 on the handle) provides a clue as what was used in the hotel dining room.

Artifacts recovered during surface collection of Lot 5 include several that can be dated. A 23/4-inch clear glass bottle with vertical ridges on three sides can be dated to $1880-1900$ based on the type of seam molds it displays. Also collected is a 14-carat goldplate-onbronze medal with a shield in the center. The medal appears to have been produced for a social or fraternal organization in the "State of Colorado" and has a date 1876 inscribed on its the face. Another interesting item is a pink porcelain doll leg with the number " 620 " on the inside of the leg. Although the significance of the number cannot be determined, the blue garter and flat- 
Table 12-1. Artifacts from the Ludlow House and Moody Site

\begin{tabular}{|c|c|c|c|c|c|c|c|c|c|c|c|c|c|}
\hline Provenience & 异 & $\frac{\mathscr{y}}{\tilde{g}}$ & $\begin{array}{l}\text { 号 } \\
\text { 总 } \\
\text { 总 }\end{array}$ & 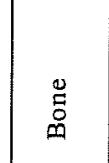 & $\begin{array}{l}\stackrel{0}{\Xi} \\
\stackrel{\Xi}{\Xi} \\
\stackrel{\Xi}{\Xi}\end{array}$ & $\begin{array}{l}\stackrel{0}{E} \\
\stackrel{\Xi}{E} \\
.0 \\
0\end{array}$ & 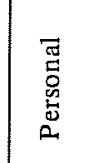 & 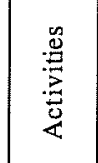 & $\begin{array}{l}\text { 會 } \\
\text { 足 } \\
\text { 总 }\end{array}$ & $\underset{\mathrm{E}}{\mathrm{E}}$ & 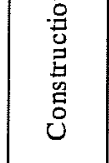 & 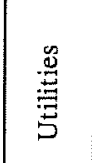 & Total \\
\hline $5 \mathrm{~A}, 18^{\prime}-20^{\prime}$ & 70 & 113 & 0 & 179 & 0 & 6 & 1 & 4 & 4 & 0 & 109 & 0 & 486 \\
\hline 5A, Post Hole & 1 & 1 & 0 & 1 & 0 & 0 & 0 & 0 & 0 & 0 & 12 & 0 & 15 \\
\hline Unit 5B, Lv. 1 & 9 & 32 & 0 & 19 & 0 & 2 & 1 & 1 & 0 & 0 & 118 & 0 & 182 \\
\hline Unit 5B, Lv. 2 & 19 & 31 & 9 & 32 & 9 & 1 & 9 & 3 & 1 & 0 & 225 & 0 & 339 \\
\hline Unit 5B, Lv. 3 & 8 & 54 & 0 & 24 & 0 & 1 & 1 & 0 & 1 & 0 & 44 & 0 & 133 \\
\hline North Wall, 8'-14' & 3 & 6 & 0 & 4 & 0 & 4 & 1 & 0 & 1 & 0 & 8 & 0 & 27 \\
\hline North Wall, 13' & 0 & 0 & 0 & 1 & 0 & 0 & 0 & 0 & 0 & 0 & 0 & 1 & 2 \\
\hline none & 16 & 5 & 0 & 1 & 4 & 0 & 1 & 1 & 0 & 0 & 8 & 0 & 36 \\
\hline North Wall, 16'-24' & 0 & 2 & 0 & 0 & 0 & 1 & 1 & 0 & 4 & 0 & 2 & 1 & 11 \\
\hline North Wall, $27^{\prime}$ & 0 & 0 & 0 & 0 & 0 & 1 & 1 & 0 & 0 & 0 & 0 & 0 & 2 \\
\hline North Wall, $3^{\prime}-18^{\prime}$ & 5 & 9 & 1 & 4 & 0 & 0 & 0 & 1 & 0 & 0 & 55 & 0 & 75 \\
\hline West Wall, $71^{\prime}-106^{\prime}$ & 1 & 4 & 0 & 2 & 0 & 1 & 0 & 0 & 0 & 0 & 25 & 2 & 35 \\
\hline Backdirt & 0 & 1 & 0 & 0 & 0 & 0 & 0 & 0 & 0 & 0 & 0 & 0 & 1 \\
\hline Unit A, Lv, 1 & 2 & 14 & 0 & 3 & 0 & 1 & 0 & 1 & 0 & 0 & 208 & 2 & 231 \\
\hline Unit A, Lv. 2a & 0 & 75 & 0 & 0 & 0 & 1 & 1 & 5 & 5 & 0 & 448 & 0 & 535 \\
\hline Unit A, Lv $2 b$ & 0 & 9 & 0 & 36 & 0 & 1 & 0 & 1 & 0 & 0 & 15 & 0 & 62 \\
\hline Unit A, Lv. 3 & 4 & 19 & 0 & 108 & 5 & 7 & 0 & 6 & 0 & 0 & 55 & 0 & 204 \\
\hline Unit A, Lv. 4 & 3 & 29 & 0 & 20 & 0 & 0 & 0 & 1 & 0 & 0 & 34 & 0 & 87 \\
\hline Unit A, Lv. 5 & 2 & 31 & 0 & 12 & 0 & 0 & 0 & 2 & 0 & 0 & 36 & 0 & 83 \\
\hline Unit A, Lv. 6 & 2 & 16 & 0 & 28 & 0 & 0 & 0 & 1 & 0 & 0 & 22 & 0 & 69 \\
\hline Unit A, Lv. 7 & 5 & 4 & 0 & 29 & 0 & 0 & 0 & 0 & 0 & 1 & 50 & 0 & 89 \\
\hline Unit B, Lv. 1 & 14 & 18 & 1 & 319 & 0 & 0 & 1 & 1 & 4 & 0 & 86 & 0 & 444 \\
\hline Lot 6, 36' & 0 & 1 & 0 & 0 & 0 & 0 & 1 & 0 & 1 & 0 & 1 & 0 & 4 \\
\hline Lot $6,35^{\prime}-55^{\prime}$ & 1 & 13 & 0 & 9 & 1 & 0 & 1 & 2 & 0 & 0 & 24 & 3 & 54 \\
\hline Lot 6, 44' & 3 & 6 & 1 & 1 & 5 & 0 & 0 & 1 & 0 & 0 & 26 & 2 & 45 \\
\hline Lot 6, 32'-38' & 6 & 13 & 0 & 5 & 1 & 3 & 2 & 6 & 7 & 0 & 276 & 1 & 320 \\
\hline Lot $6,32^{\prime}$ & 1 & 0 & 0 & 0 & 0 & 0 & 0 & 0 & 7 & 1 & 0 & 0 & 9 \\
\hline Lot 6, 55'-58' & 0 & 5 & 0 & 0 & 1 & 3 & 0 & 0 & 1 & 0 & 0 & 0 & 10 \\
\hline Ludlow Privy & 11 & 39 & 0 & 5 & 2 & 1 & 0 & 0 & 5 & 0 & 39 & 4 & 106 \\
\hline $7 \mathrm{~A}$, Lv. 1 & 7 & 18 & 0 & 329 & 21 & 0 & 0 & 0 & 2 & 0 & 103 & 0 & 480 \\
\hline 7A, Lv. 2 & 11 & 43 & 0 & 158 & 3 & 3 & 0 & 4 & 1 & 0 & 53 & 0 & 276 \\
\hline 7A, Lv. 3 & 44 & 129 & 0 & 31 & 13 & 1 & 2 & 0 & 0 & 0 & 74 & 0 & 294 \\
\hline 7A, Lv. 4 & 75 & 333 & 0 & 113 & 5 & 0 & 0 & 4 & 1 & 0 & 89 & 0 & 620 \\
\hline $7 \mathrm{~A}$, Lv. 5 (SW) & 4 & 19 & 0 & 11 & 0 & 0 & 1 & 0 & 0 & 0 & 70 & 0 & 105 \\
\hline $7 \mathrm{~A}$, Lv. 5 (NW) & 31 & 53 & 0 & 29 & 0 & 0 & 0 & 0 & 1 & 0 & 44 & 0 & 158 \\
\hline $7 \mathrm{~A}$, Lv. $6(\mathrm{NW})$ & 14 & 53 & 0 & 22 & 0 & 0 & 0 & 1 & 0 & 1 & 55 & 0 & 146 \\
\hline $7 \mathrm{~A}$, Lv. 6 (SW) & 10 & 3 & 0 & 2 & 0 & 0 & 0 & 0 & 0 & 0 & 16 & 0 & 31 \\
\hline $7 \mathrm{~A}$, Lv. 7 & 9 & 33 & 0 & 0 & 0 & 0 & 0 & 1 & 0 & 0 & 22 & 0 & 65 \\
\hline 7A, Lv. 8 & 16 & 43 & 0 & 2 & 0 & 0 & 0 & 1 & 0 & 0 & 0 & 0 & 62 \\
\hline 7B, Lv. 1 & 0 & 2 & 0 & 0 & 0 & 0 & 0 & 0 & 0 & 0 & 0 & 0 & 2 \\
\hline 7B, Lv. 2 & 4 & 10 & 0 & 1 & 0 & 0 & 0 & 0 & 0 & 0 & 4 & 0 & 19 \\
\hline Lot $7,54^{\prime}-68^{\prime}$ & 1 & 9 & 0 & 0 & 0 & 2 & 0 & 0 & 1 & 0 & 25 & 1 & 39 \\
\hline Lot 7, surface & 1 & 4 & 0 & 4 & 1 & 4 & 0 & 1 & 4 & 0 & 2 & 0 & 21 \\
\hline Totals & 413 & 1302 & 12 & 1544 & 71 & 44 & 25 & 49 & 51 & 3 & 2483 & 17 & 6014 \\
\hline$\%$ of Total & $6.87 \%$ & $21.65 \%$ & $0.20 \%$ & $25.67 \%$ & $1.18 \%$ & $0.73 \%$ & $0.42 \%$ & $0.81 \%$ & $0.85 \%$ & $0.05 \%$ & $41.29 \%$ & $0.28 \%$ & \\
\hline
\end{tabular}


heeled brown boot on the leg place it in the time period of 1855 to 1870 (Noël Hume 1969:318).

In the category of household ceramics, a base ring foot of a small decorated cup has a maker's mark with "Germany" printed on the base. According to Poche (1974:868), the cup was manufactured in Oberkatzau by Greiner \& Herda sometime after 1893. Other fragments of decorated porcelain cannot be dated and while several of the fragments have been partially reconstructed, cross-mending with fragments of other proveniences has not been possible.

A portion of an underglaze-decorated porcelain plate with a maker's mark "Libertas/Prussia" is especially interesting. The design is composed of two pears on a branch with blue-gray repoussé along the rim of the plate. An intensive search of the literature failed to identify the name or date of the manufacturer.

A key tag from the Hotel Zieger in El Paso, Texas, was found in the Provenience 9 location. According to Mary Sarbor of the El Paso Public Library (personal communication 1986), the hotel was located at two different sites in El Paso in the early 1900s. Perhaps the traveler who neglected to turn in the key for room 122 at the hotel in El Paso also stayed at the Ludlow House/New Commerce Hotel in San Antonio.

Numerous glass bottles, whole and fragmented, were found and an approximate date has been assigned to several of them, based on seam molds. A cobalt blue screw-top jar can be dated to the post-1900 period. A partial clear glass medicine bottle of the stoppered variety dated to $1880-1900$, while a $33 / 4$-inch clear glass rectangular bottle can be dated to post- 1900 .

Surface-collected artifacts also include numerous items that cannot be assigned to a definite time period but are consistent with the types of artifacts found in the project area. Scrap metal, a large metal strap fastener, wire nails, charcoal, green-painted plaster, and porcelain insulators are some of these items. Some personal items include a man's leather half-sole for a shoe, a pocketknife, a green marble, a bone brush handle, and buttons and pins. Green, amber, aqua, and clear glass fragments were recovered as well as a black bottle cap with a hole in the top. In addition to the porcelain, ceramic sherds also include stoneware, whiteware, and a lusterware cup or dish handle.

One small, clear glass round bottle was recovered from the backdirt. Manufactured after 1877, it was used by the L. D. Caulk Company of Philadelphia and at one time contained crown-bridge and gold inlay cement used in dentistry.

\section{Unit 6A - Brick-lined Privy Pit}

Unit $6 \mathrm{~A}$, found during clearing of the area, was a bricklined privy pit identical to the one found on Lot 2, site 41BX641. This feature was excavated in six inch levels and all soils were screened. Artifacts recoved from Unit 6A are listed in Table 12-1.

The heaviest concentration of artifacts was removed from Level 2, 6-12 inches below the surface. Construction or workshop-type materials include two large bags of window glass, leather fragments, a pipe nipple, metal fragments, metal tubing, wire nails, screws, a metal rod, and a metal lid with a handle. Some perforated metal fragments may have been a sieve of some type. A pocketknife, safety and straight pins, buttons, and the upper portion of a metal container with a screw top were collected from Level 2. Glass items include aqua, green, and clear fragments as well as two glass stoppers, of which one decorative one was possibly for a decanter. A whiskey bottle made by the Mlinois Glass Company, Alton, sometime during 1916 to 1929 has been partially reconstructed.

A small bisque doll's head was partially reconstructed with fragments from this unit. "Germany" appeared on the back of the torso and based on enactment of the Tariff Act of 1890, when imports had to be labeled with the country of origin, the doll was probably manufactured between 1892 and 1900.

Slate, mortar, metal, and brick fragments and window glass were collected from level 3 . Various glass fragments including lamp glass, buttons, and flower pot fragments were recovered. Ceramics in Level 3 include stoneware, porcelain, and undecorated whiteware. 
Levels 3, 4, 5, and 6 include a similar assortment of cultural material. One item that dates to the post- 1850 period is a Frozen Charlotte doll with the head, hands, and lower legs missing.

\section{Unit 6B - Test Trench}

Unit $6 \mathrm{~B}$ was a $2-\mathrm{x}-15-\mathrm{ft}$ hand-excavated trench excavated to a depth $2.5 \mathrm{ft}$ below the disturbed, artifact bearing deposits. The purpose for this unusually deep excavation was to reveal the depth and construction method of the yellow-brick wall foundation and footing observed in here (Figure 12-2).

Four items recovered from Unit $6 \mathrm{~B}$ can be assigned an approximate date. A Listerine bottle used by the Lambert Pharmacal Company up to 1915 was manufactured by the Obear Glass Company, East St. Louis, Illinois (Toulouse 1971:373-375). A cobalt blue bottle base can be dated to the post-1916 period. It was manufactured by the Maryland Glass Company for the Emerson Drug Company and was used for bottling Bromo-Seltzer and other related drug products (Toulouse 1971:339).

One of two metal buckles has "Nov.13/23" on the back. While the buckle could conceivably have been patented in 1823 (the U.S. Patent Office was established in 1802), the date is more likely 1923 judging from the other artifacts found in this unit and the fact that the buckle appears too new to have been made any earlier.

One last item that dates to 1930 or later is a small red cast iron toy car. A resource book on toys (Schroeder 1971:230) identifies the car as a model 6-02 coupe, part of a package offered for sale in the 1930s. Two wheels are missing, but a wheel from Lot 6, Unit A appears to fit the little car.

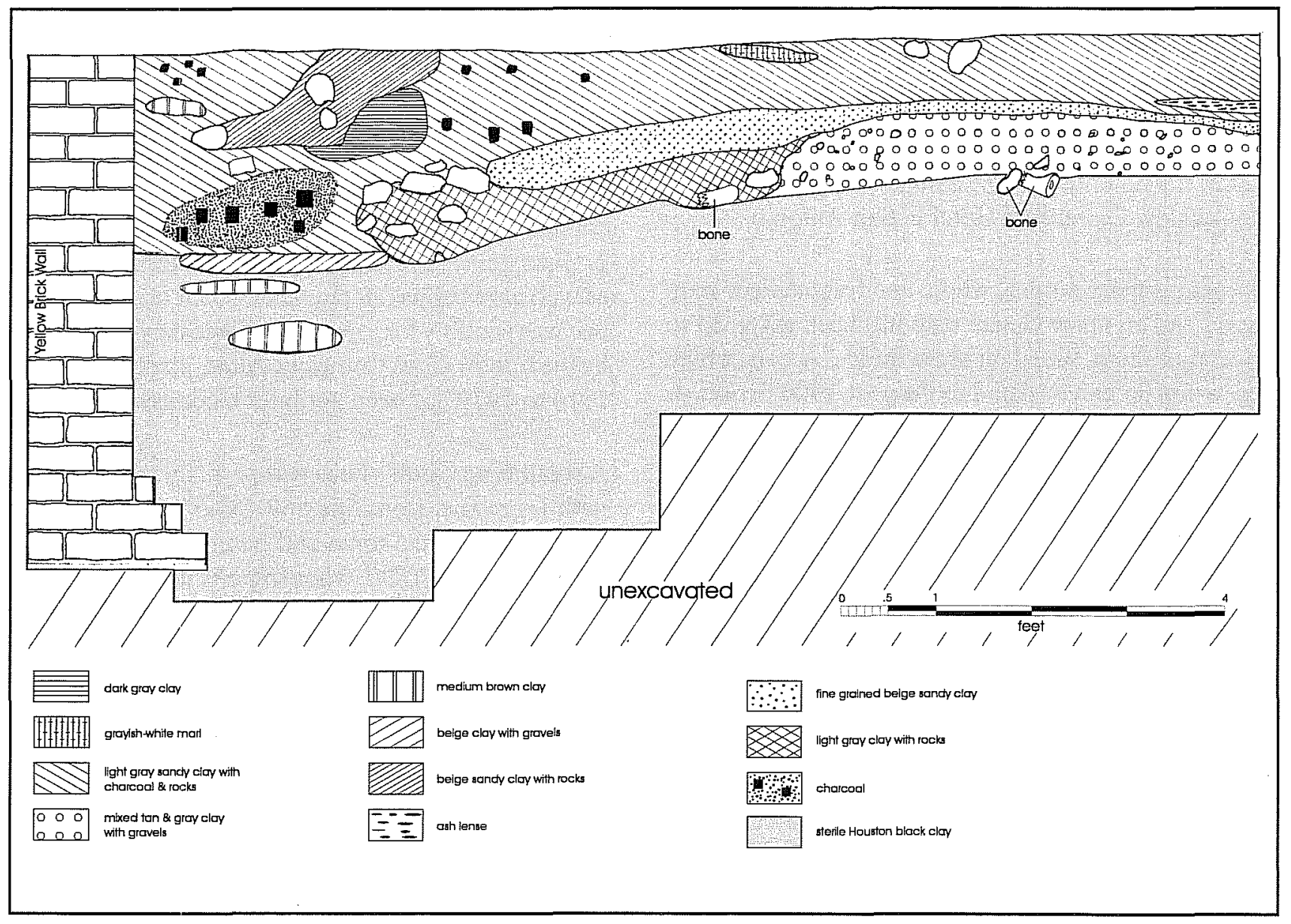

Figure 12-2. Profile of east wall of Unit B in Lot 6. 
Several interesting but undatable items include a compact containing a mirror and inscribed "Daydream." It was first made by Stearns Perfumer of Detroit and Paris. Another item is a nameplate for a Belding-Hall Century refrigerator. A literature search has failed to provide any information on the date of manufacture. A Number 9 billiard ball was also recovered from this unit.

Construction/workshop materials are numerous in Unit B. Included are wire and cut nails, bolts, screws, nuts, spikes, metal scraps, copper fragments, window glass fragments, coal, metal pipe, cast iron fragments, hardware, door parts, and an angle iron.

Personal items found include a slate pencil, comb, metal purse frame, key, marbles, a brush handle, a whistle mouthpiece, pencils, buttons, and shoe eyelets.

Household items include a partial metal spoon, a bluing bottle, a clock part, knife blade, candle holder, a clay bird, and half of a ceramic doorknob. Ceramics are numerous. Stoneware, decorated and undecorated whiteware, and plain colored ceramics were collected. Some reconstruction of ceramics was possible. A goldrimmed whiteware cup was reconstructed of fragments from this unit and from Unit B of Lot 7, which also was a surface collection. Green, amber, clear, aqua, and blue glass fragments and some lamp glass fragments were also collected.

\section{Unit 7A - Privy Excavation}

This brick-lined privy pit measured 4-x-5 ft in area and was excavated in eight arbitrary one-foot levels. Artifacts recovered from Unit 7A are listed in Table 12-1.

The usual assortment of cultural material was collected as well as several unusual items. Construction-type materials include wire and cut nails, plaster, slate, bluepainted plaster, and window glass fragments. Materials that might have been found in a stable/workshop environment include tin scraps, a partial metal chain, an eye-bolt, a partial horseshoe, copper fragments, and a 22 caliber shell case. One puzzling item is a large sheet of lead with a round portion cut out of one end.
Personal items include cloth fiber, a slate pencil, a portion of a clay tobacco pipe, a collar button, and a blue marble. An interesting item is a copper tip for a bola tie with a cloth fragment still inside the tip. Four fragments of a chain, possibly a watch chain, were recovered from levels 4,5 , and 6 , as well as two fragments of a heavier chain which may have held a watch fob.

White and clear lamp chimney glass fragments were recovered from this unit. Glass container fragments collected include clear, white, aqua, amber, and green. Several neck fragments can be dated to $1880-1890$, based on seam molds. One clear glass fragment of a panel bottle with partial lettering on it may have contained one of the Louden products being distributed after 1876(Wilson 1981:135). Included in the Louden Company's array of products were Oriental hair tonic, female elixir, fever and ague pills, Indian expectorant, pile remedy, sanative pills, and tonic vermifuge.

Ceramics recovered from Unit 7A are quite numerous and some cross-mending was possible with the contents of Unit 7B. Levels 3, 4, and 6 contained the greatest amount of undecorated whiteware. Three items partially reconstructed through cross-mending include two small dishes and a cup.

Several Ironstone pieces had partial maker's marks, although only one was identifiable. This piece appears to have been manufactured by $\mathrm{J} \& \mathrm{G}$ Meakin, Hanley, England after 1890 (Godden 1964:427). One mark on a partially reconstructed small dish is probably from a potter in New Jersey, but further identification is not possible.

The face and hair of a porcelain figure was found in Unit A but cannot be dated. Porcelain tableware fragments were recovered in levels 2, 4, and 5 of Unit $A$ and some cross-mending was accomplished. It was possible to fit together two fragments that appear to be part of the same thin porcelain dish, cup, or small plate. Two pieces of porcelain also formed a partial base of a cup or small dish. One piece of porcelain has three gold lines decorating the rim.

Stoneware fragments were present in all levels of Unit A. Nineteen of the fragments were obviously from six 
different crocks/jugs but little reconstruction was possible. Ten other assorted stoneware fragments were parts of different containers. It is possible that 16 storage crocks were in use a some time at the Ludlow House. The storage crocks were salt-glazed as well as lead-glazed. One partially reconstructed salt-glazed jug bore the letters ". . . F. I. MEY ..." and ". . INE8". J. F. W. Meyer and Franz Schultz founded the Meyer Pottery near Atascosa, Texas in 1887 (Greer and Black 1971:1).

\section{Unit 7B-Surface Collection}

Unit 7B consisted of miscellaneous cultural material recovered during surface collecting and is listed in Table 12-1. While the information derived from the surface collection may not be a reliable as that derived from controlled excavations, quite a few artifacts can be dated. The neck and shoulders of a clear glass bottle contained the name "BROOKS" on one portion. Based on the seam molds, it dates to post-1900. Another clear glass neck fragment is also dated to $1900+$. A clear glass, 6-1/4-inch condiment bottle is from a slightly earlier time, ca. 1880 to 1900.

One interesting cobalt blue glass fragment contains the following inscription: "THIS CUP HOLDS/ A HEAPING DESSERT SPOONFULL."' Containing an unknown medicine, it was manufactured by John Wyeth \& Sons during the period 1880 to 1890 . The fragment was part of a top for a square 5-1/4-inch "corker" bottle.

A complete, 121/2-inch green wine bottle was part of the surface collection on Unit B. The bottle, without seam mold lines, can be dated to ca. 1840-1870 based on the laid-on ring and the lip and the improved pontil mark on the kick-up base (Newman 1970:72-73). However, horizontal striations on the body indicate the bottle may have been made using a turn-paste mold. Kendrick (1966) dates use of the turn-paste mold to 1880-1890 and Newman (1970) says 1870-1890. Apparently some early glass manufacturing techniques were retained at the same time as more modern techniques were being incorporated.
Personal items found include a slate pencil, a comb, a metal purse frame, a key, marbles, a brush handle, a whistle mouthpiece, pencils, buttons, and shoe eyelets.

Household items include a partial metal spoon, a blueing bottle, a clock part, knife blade, a candle holder, a clay bird, and half of a ceramic doorknob. Ceramics are numerous. Stoneware, decorated and undecorated whiteware, and plain-colored ceramics were collected. Some reconstruction of ceramics was possible. A gold-rimmed whiteware cup was reconstructed from fragments from this unit and from Unit 6B, which was also a surface collection.

\section{Discussion}

The Ludlow House was a typical hotel/boarding house of turn-of-the-century San Antonio. The use of this peculiar 84-foot-long brick structure along the north boundary of Lots 5,6, and 7, has not been determined. Sanborn Insurance Maps refer to this and any other backyard structures as outhouses. Apparently in the nineteenth century this term was customarily used for any support structure in the back yard, since we quickly learned during this project that such buildings did not always contain privy pits. The amazing amount and variety of artifacts found in the footprint of this building suggest that trash was tossed here indiscriminately during the late nineteenth to early twentieth centuries. Various types of test units, trenches, and surface collecting failed to reveal the reason for the building's construction. We did find that the foundations were unusually deep and that a row of cedar posts ran just off-center down the length of the building (Figures 12-1 and 12-2). Whether these supported the floor or the roof could not be determined. Other cedar posts found in test trenches indicated that other outbuildings were in the same area, either before or after the brick structure.

Apparently the privy on Lot 7 (Unit 7A) was demolished and filled before the brick outbuilding was built. The artifacts recovered from it dated before 1900 . The privy must have been built for the dwelling present on Lot 7 when Mr. York lived there in 1898. It was lined with the same cheap Laredo brick as the one on Lot 2, brick which began to arrive in San Antonio in the late 1870 s. 


\section{Chapter 13: The Fischer Site}

Site Identification: Fischer Residence, NCB 152 Lot 78

Address: 11 (later 111) Bowie Street

Trinomial: $41 B \times 638$

\section{Historical Background}

Venaz Fischer bought Lot 78 in New City Block 152 from Charles Riotte on September 10, 1854. On May 30, 1855, Venaz Fischer and Katharina Ulrich were married in San Antonio, with Jacob Seng and John Petras as witnesses (Vital Statistics, Marriage Book C:291). Sometime soon afterward, they built a house on the lot Fischer had bought at 11 Bowie Street (Figure 13-1).
According to Koch's 1873 bird's-eye map, the house they built was typical of the small, adobe houses popular in San Antonio during the mid-nineteenthcentury, with porches on the front and back and a small frame structure, probably a kitchen, built separately behind it. These structures occupied the south half of the lot, suggesting that the intention was eventually to build an additional house on the north half. This is identical to the development of the Mueller lot, suggesting that it was not unusual for these frugal people to plan ahead to get the best possible use of their property.

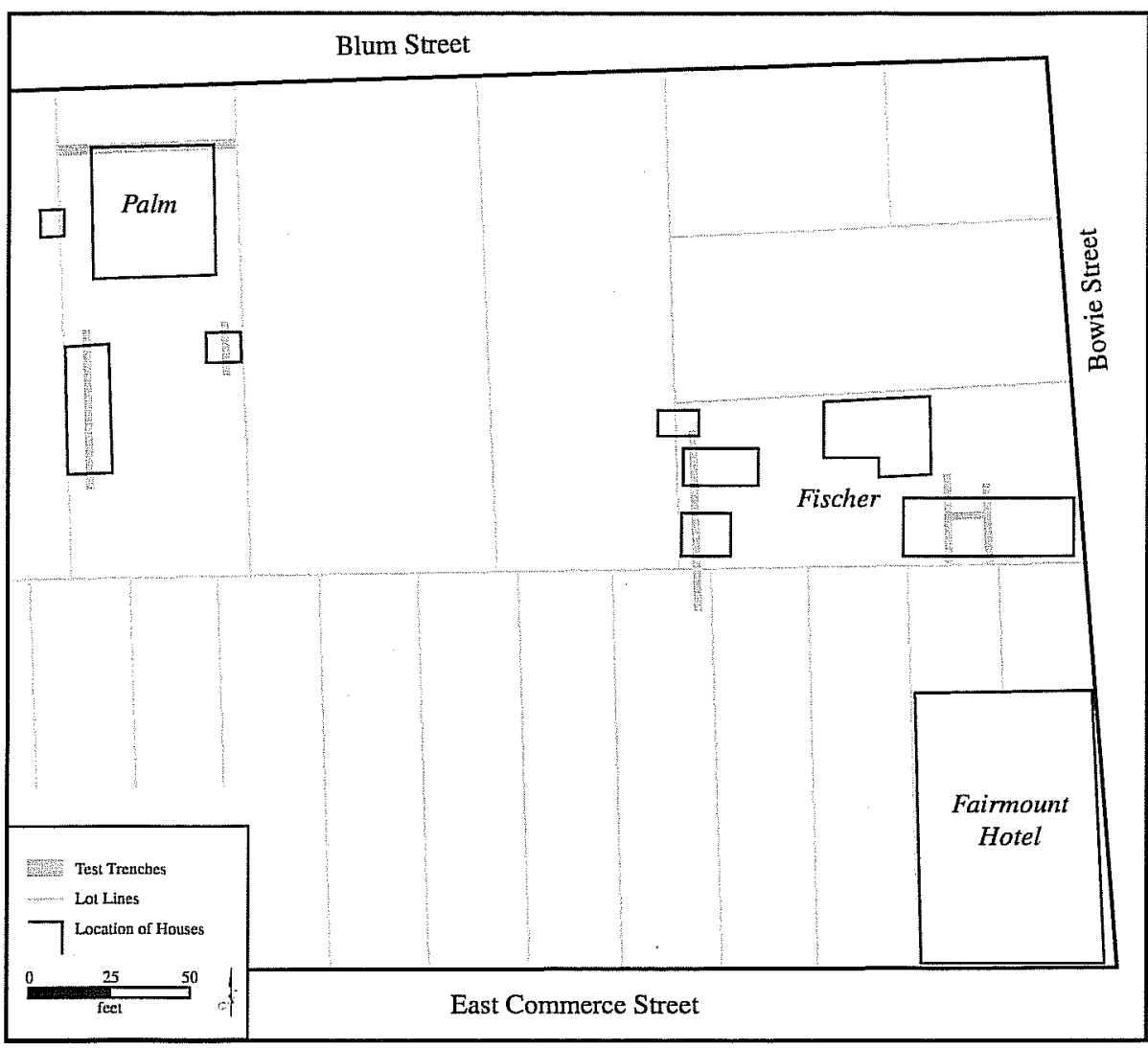

Figure 13-1. Location of the Fischer and Palm sites and the Fairmount Hotel.
Sometime before $1877, \mathrm{Mr}$. Fischer died, leaving his widow the property. She lived there alone, until 1881 , when the City Directory records her son, Ferdinand, as living at 15 Bowie, which was one of two frame houses built on the west half of the lot sometime before 1892 (Figure 13-1). The following year, Mrs. Fischer was also living at 15 Bowie, probably renting out the adobe house.

Mrs. Fischer continued to be listed as living at 15 Bowie until the 1889-1890 City Directory, after which it seems that she either moved away or died. It must have been at about this time that the houses at 11 and 15 Bowie became rental units, including the small frame structure behind the adobe (Figure 13- 
1). The houses at 11 and 15 Bowie both became rental units from this time forward. At sometime between 1896 and 1904 (Sanborn Insurance Maps), the adobe and frame houses and their outbuildings were razed and replaced by three frame houses. At the same time several new small frame structures appeared near the back of the lot. The Bowie Street house numbers had been changed to 111 and 113 by 1896 .

From this time until the early 1950s, these houses are listed as rentals in the City Directories. They do not appear at all in the 1957 directory, which probably indicated that they had been torn down during the past year.

\section{Archaeological Investigations}

The site of the original Fischer house at 11 Bowie Street (later 111 Bowie) was chosen for testing because of its long history as a rental unit and the later construction of a frame house on the site. The first backhoe trench, Trench 1, was excavated across the entire back of the lot, about $10 \mathrm{ft}$ inside the back lot line (Figure 13-1). The intent was to search for privies, trash pits, and any indications of the construction of the later (post-1896) structures in this area (Figure 132). The location of this trench was based on previous experience on other lots in the downtown area, where privies were located just inside the back lot line. The trench was also continued across the south lot line in a search for indications of an acequia branch suggested there by some of the earliest deed records.

Test trenches 2, 3, and A were excavated across the area where the adobe house and the later frame house had stood (Figure 13-3). At first the pattern of stone foundations was a surprise to the excavators, as they did not appear to match the layout of the adobe house as recorded on the Sanborn Insurance maps for 1892 and
1896. However, when the field drawings were compared to those of other similar houses in the Alamodome project area, it became apparent that we had found the northwest corner of the original house in Trench 3 and the north and west walls of a later addition to the house in Trenches $\mathrm{A}$ and 2 . The differences in construction between the two foundations reinforced this conclusion.

A row of cedar support posts in Trench 2 was the expected evidence for the frame rent house built on the same general site about 1900 . Similar construction has been recorded by archaeological projects at Vista Verde South (Labadie 1987) and the Alamodome (Fox et al. 1997). It appears that when the first house was demolished, the remains of the super structure were completely cleared from the lot, since no trace of it was found during the test trenching.

No trace of the acequia was found in Trench 1 . Apparently, as at NCB 166 and NCB 1010, the acequia branches that ran east-west through this area were ephemeral, mud-lined ditches that were quickly erased after they went out of use, probably soon after secularization of Mission Valero in the 1790s. There were also no foundations or other disturbances from the twentieth-century outbuildings.

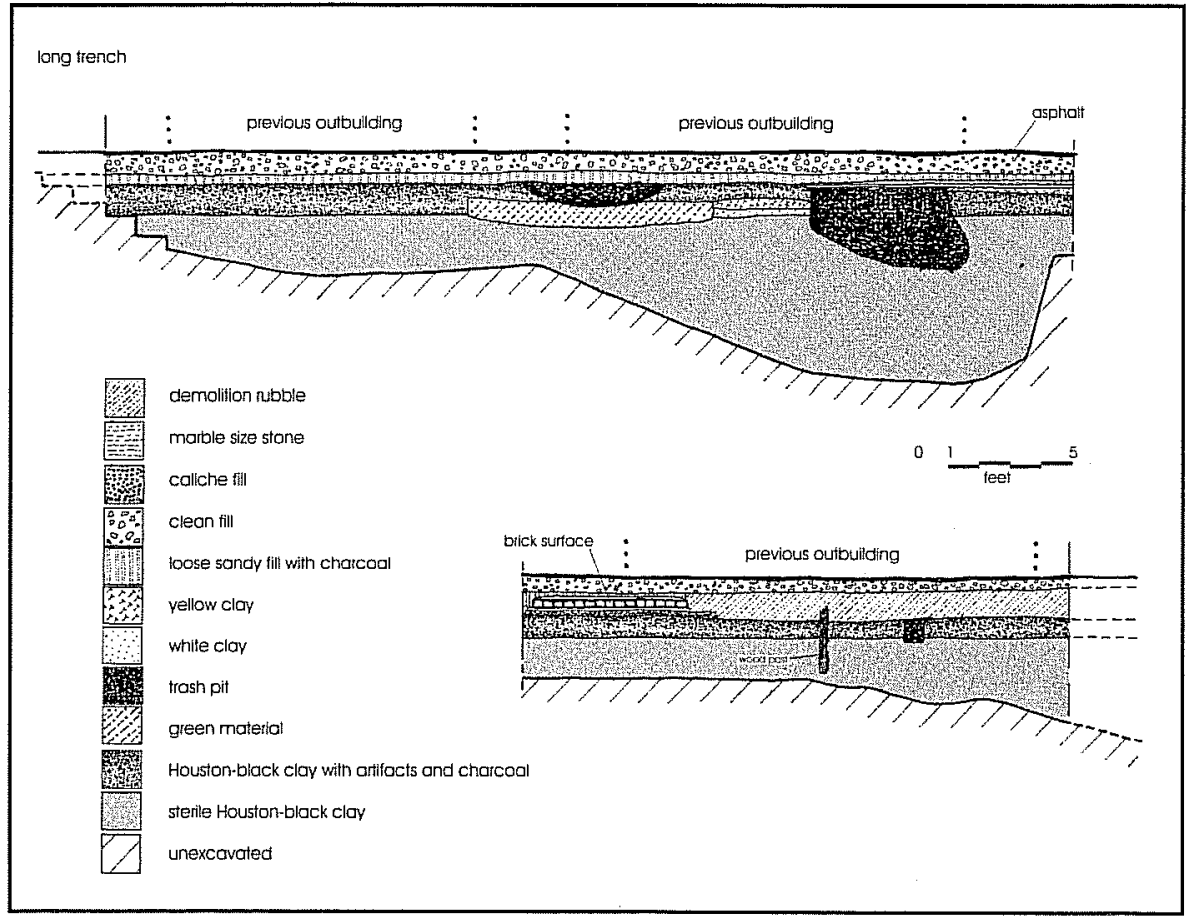

Figure 13-2. East profile of Trench 1 across back of Fischer lot. 


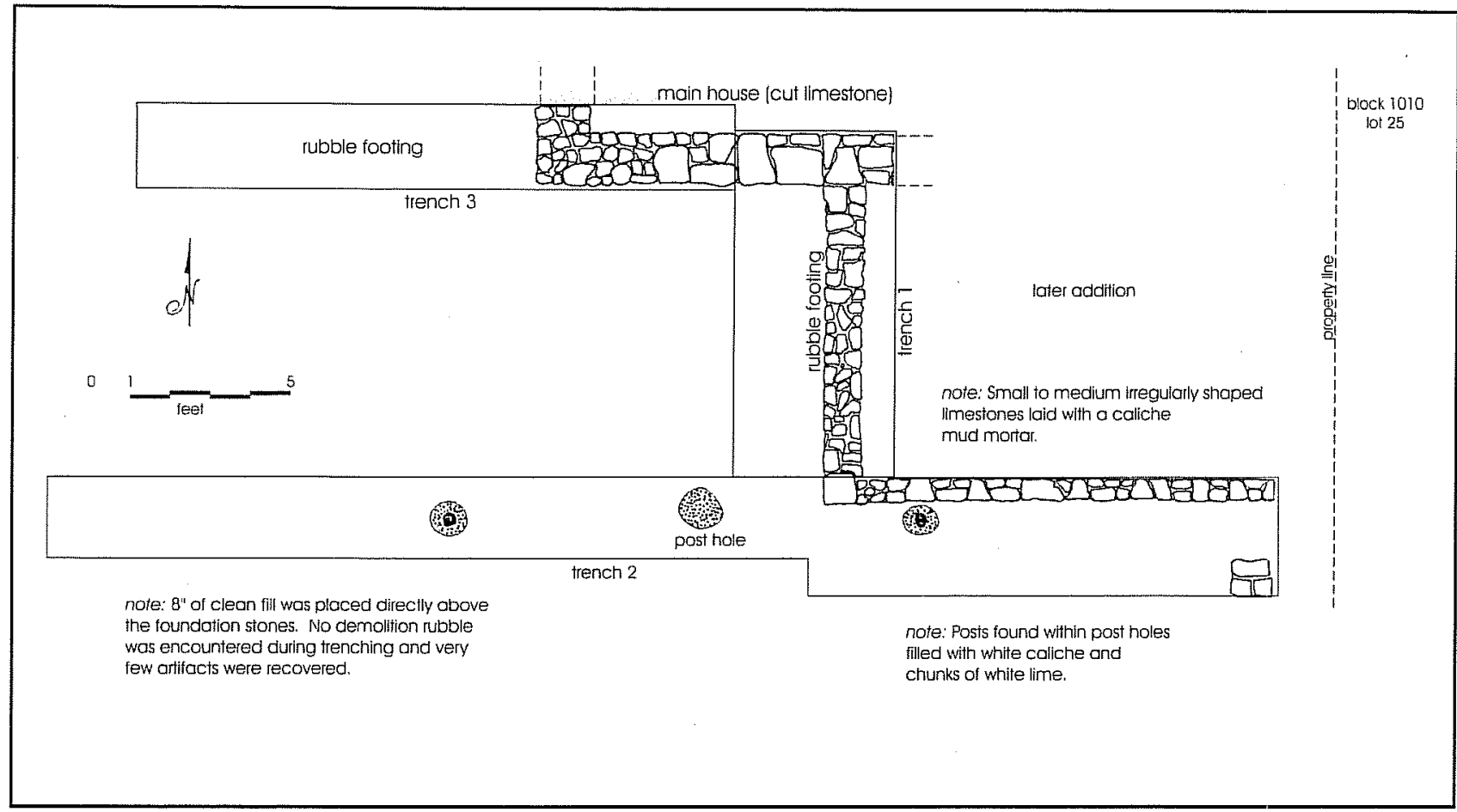

Figure 13-3. Excavations at the Fischer house.

A trash pit, ca. six $\mathrm{ft}$ in diameter, was found beneath the location of one of the outbuildings (Figure 13-2). A $2 \mathrm{ft} \times 4 \mathrm{ft}$ excavation unit was excavated in the approximate center of the trash pit to examine the contents. The west profile of the excavation (Figure 13-4) indicated that there was a layer of dark, silty artifact-bearing soil above the top of the pit (Level 1) which extended beyond the edges of the pit.

Artifacts in this deposit dated to the 1880 to 1920 period (Table 13-1). These included sherds of lead glazed earthenware and undecorated whiteware, cheap porcelain (probably Oriental) and a fragment of a Bristol glazed stoneware jug which dates between 1900 and 1920 (Greer 1981:212). The glass present was all clear glass, and a surprising total of 29 buttons dated between 1870 and 1900 or later. Various other small articles (Figure 13-5) such as porcelain doll parts and doll dishes, slate fragments, beads, watch parts, and an eyeglass lens suggest the area was used for discard of household trash, either during or just after the house at 11 Bowie was occupied. The presence of both wire and cut nails in a proportion of 8 to 1 , and a large amount of window glass indicates that a turnof-the-century structure was dismantled or perhaps burned in place in this area.

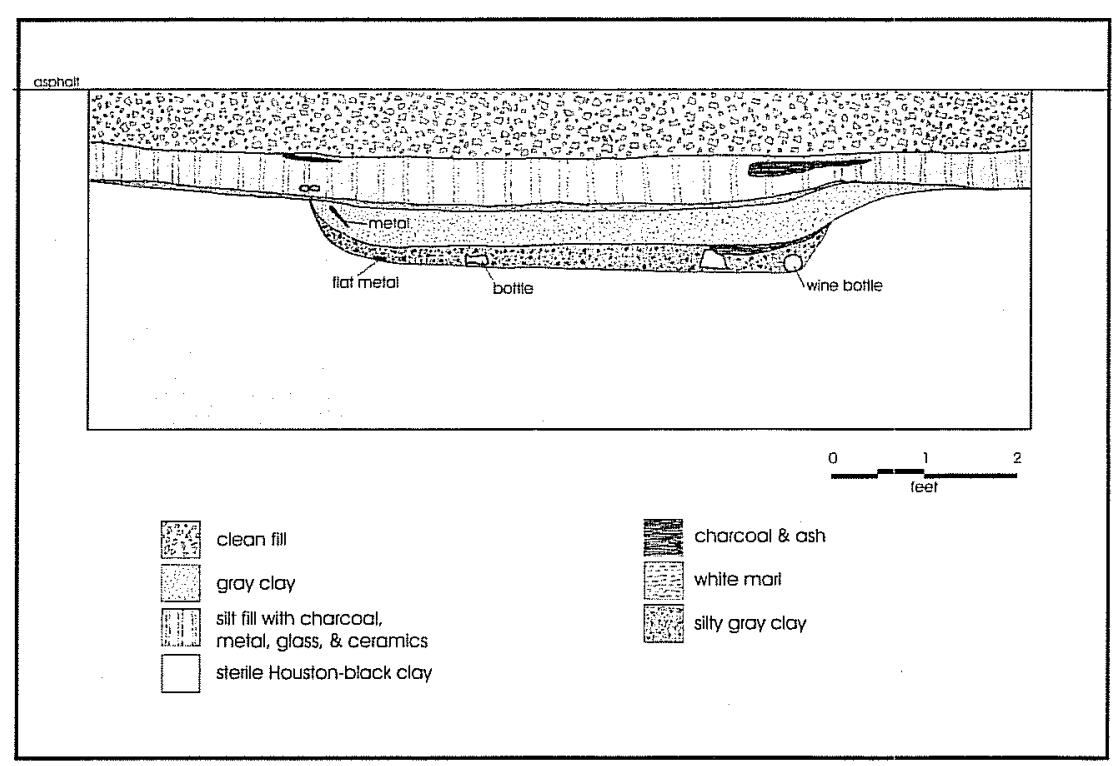

Figure 13-4. West profile of trash pit. 
Table 13-1. Artifacts from the Trash Pit

\begin{tabular}{|c|c|c|c|c|c|c|c|c|c|c|c|c|}
\hline Level & 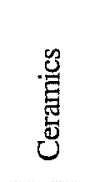 & $\begin{array}{l}\text { D } \\
\text { 啬 }\end{array}$ & 咅 & 号 & 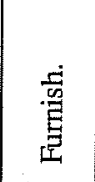 & $\begin{array}{l}\text { 昙 } \\
\text { 总 }\end{array}$ & $\begin{array}{l}\text { ]ू } \\
\text { : } \\
\text { t. } \\
0\end{array}$ & 总 & 貝 & 首 & 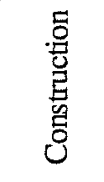 & Total \\
\hline 1 & 30 & 296 & 13 & 228 & 7 & 32 & 10 & 29 & 55 & 4 & 1565 & 2270 \\
\hline 2 & 1 & 7 & 12 & 29 & 0 & 1 & 1 & 1 & 0 & 0 & 113 & 167 \\
\hline 3 & 4 & 38 & 265 & 222 & 2 & 3 & 0 & 7 & 22 & 0 & 279 & 845 \\
\hline Total & 35 & 341 & 290 & 479 & 9 & 36 & 11 & 37 & 77 & 4 & 1957 & 3276 \\
\hline $\begin{array}{l}\% \text { of } \\
\text { Total }\end{array}$ & $1.07 \%$ & $10.41 \%$ & $8.85 \%$ & $14.62 \%$ & $0.27 \%$ & $1.10 \%$ & $0.34 \%$ & $1.13 \%$ & $2.35 \%$ & $0.12 \%$ & $59.74 \%$ & \\
\hline
\end{tabular}

Beneath this deposit, a thin layer of white caliche appeared to seal off the trash pit. The upper level of the pit was a gray clay with no ash or charcoal with a few artifacts, which appear to be related to those in the deposit above. The lower level was a silty gray clay with large charcoal chunks throughout. The only ceramics were a few undecorated whiteware sherds and one sherd of banded slip ware. Most of the glass continued to be clear. The major difference in this level was the presence of multiple fragments of rusted tin can scrap and metal strapping. The proportions of wire to cut nails here was 4 to 1 . The most interesting artifacts recovered from this level were a blown-in-mold black glass bottle (Figure 13-6) bearing the mark "K/17." According to Toulouse (1971:299), this mark was used by the Kinghorn Bottle Company of Scotland which was in operation between 1907 and 1920 . However, the workmanship and the comparatively heavy weight of the bottle suggests a date in the late nineteenth century. Also present was a medicine bottle which once contained Syrup of Figs, made by the California Fig Syrup Company in San Francisco (Figure 136). Syrup of figs was a laxative popular in the late nineteenth century and listed for sale in the 1897 Sears, Roebuck and Company catalog (Israel 1968:29). The embossed label and absence of evidence of an automatic bottle machine mark also date this bottle before 1903. Delicate white porcelain doll dishes (Figure 136) present in this deposit also suggest this earlier date.
The evidence of the rather close but nevertheless different dating of the backyard debris (Level 1)and the bottom of the trash pit (Level 3) is understandable in the light of the events that transpired in this portion of the Fischer site. The contents of the pit would represent discards during the early renting of the house, between ca. 1883 and ca. 1900 when the house and kitchen were razed. The artifacts in the backyard debris above the pit would have accumulated partly from the demolition (numerous nails and window glass sherds) and the later tenants of the frame house that was built over the adobe house. The relatively early cut-off date for the backyard deposit suggests that the frame outbuilding built over the area protected it from further trash scatter.

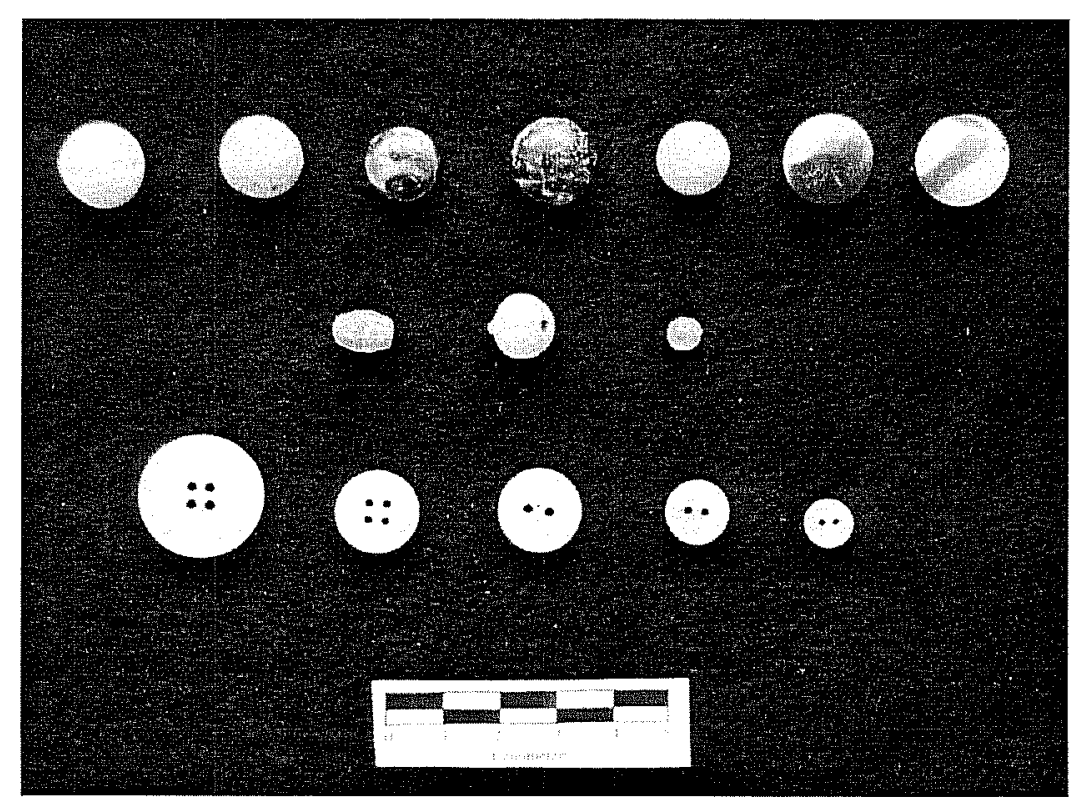

Figure 13-5. Small artifacts from the trash pit. 


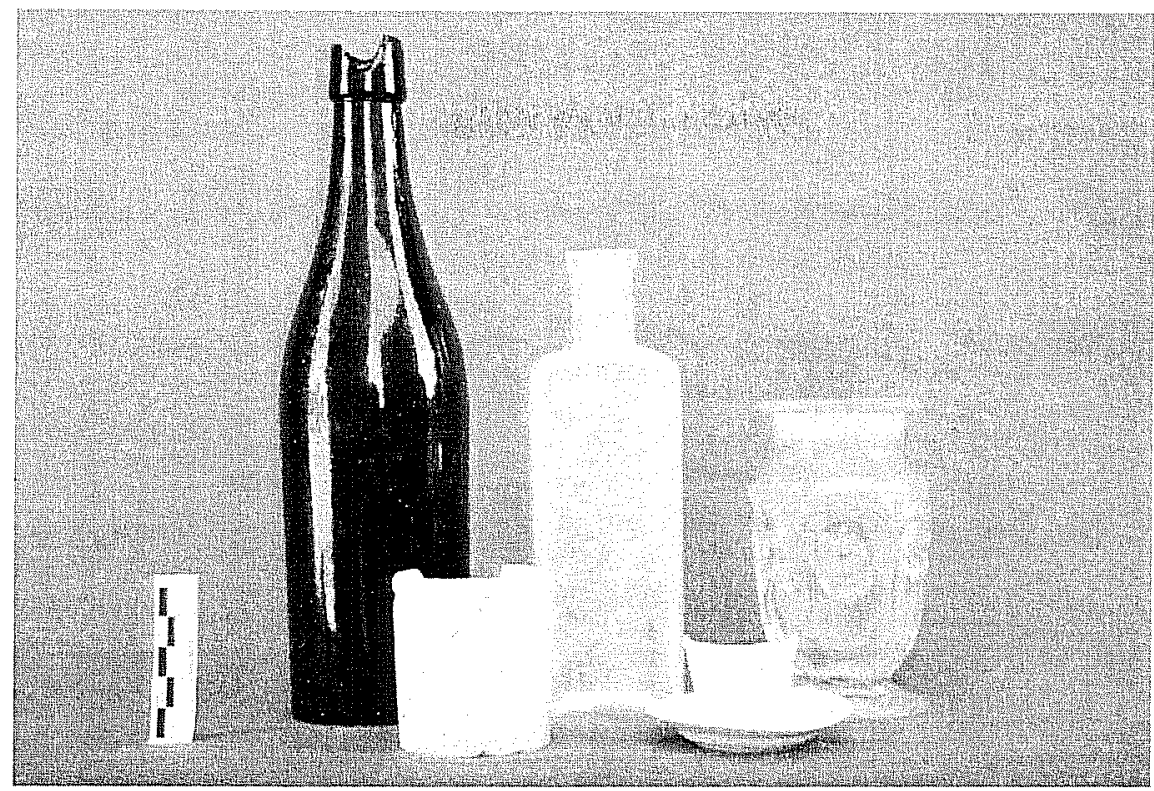

Figure 13-6. Bottles and ceramics from the trash pit.

More important than these dating details, however, are the lists of artifacts recovered from this small part of the backyard area. The source of these artifacts would have been the tenants who rented the adobe house and the later frame house during the period of 1881 to sometime in the early 1900s. It appears that most of these were families with small children, to judge from the number of toys. The number of clothing and personal items also suggest family life. The large number of buttons may have resulted from the location nearby of a backyard clothes washing operation, not uncommon at that time. The absence of numerous ceramic sherds may be a result of the relative poverty of the renters and the almost annual turnover in the families renting the house. The artifacts are quite similar to those recorded at the Wilson Boarding House at Wallisville, Texas (Fox et al. 1990:123), which saw a similar constant turnover of residents during this same time period. A comparison of the discards from the two sites demonstrates the similarity of family life throughout the region during this period. "Personal articles included numerous tiny objects, such as hooks, buttons, and snaps for fastening clothing, small brass buckles and hinges, shoe lace eyes, and part of a fancy cuff link. The presence of children is indicated by parts of several porcelain doll heads and bodies and a broken doll's tea set, as well as clay marbles and parts of a slate and slate pencil" (Fox et al. 1990:123).

\section{Discussion}

It is interesting to compare the behavior of the Fischer family with that of the Mueller family in dealing with the problem of a widowed mother with little or no financial support who remains in the family home alone. In each case, the eventual solution seems to have been to turn the homestead into a money-making proposition by building rental housing on it. In both cases, the rental housing was built during the same period (between 1896 and 1904).

The accumulation of artifacts from the trash pit and the yard deposit above it can be compared with those recovered from the Ludlow House site. Both would seem to represent accumulations one could expect to find as evidence of a transient occupation such as would accumulate on the site of rental or hotel property, in particular as many or more personal and clothing items than household items. 


\section{Chapter 14: The Palm House}

Site Identification: The Palm House 41 BX639 (New City Block 152, Lot 75)

Address: 240 Blum Street

Trinomial: 41BX639

\section{Historical Background}

CAR archaeologists investigated the Palm House (Figure 13-1) in December 1984 and again in March 1985. The site was chosen for testing as an example of a modest adobe built after the Civil War and occupied by a middle-class German family for a comparatively long period of time.

Friedrick ("Fritz") Palm purchased the lot in June 1867 from Charles N. Riotte. There is no evidence that Riotte ever occupied or constructed a dwelling at the site. Palm was born in Haenlopeza, Prussia in 1825 (Texas Department of Health, Vital Statistics, Death Certificate [on file at CAR]). He arrived to the United States at the Port of Galveston (Texas) on December 5, 1855. There is record that Palm applied for naturalization on August 6,1860 , and that his citizenship was granted on July 15, 1867 (Index to Naturalization Records, 4th Civil Minutes, Book F:71 and 494; Original papers filed Box B, Document 50, Vault District Court). The 1870 U.S. Census recorded that Palm was married to a woman named Friedricka, who was six years his junior, and that they had two children, Rudolph (born ca. 1863) and Ida (born in 1867). Various city directories identified Palm's occupation as a carpenter. Palm constructed an "adobe" house soon after he acquired the property. Fritz Palm died on November 8, 1877, of dropsy (edema). His will was written on September 11, 1877 , and filed on January 7, 1878; the will contained no information that was enlightening about the family. Friedricka apparently died between 1898 and 1912 as her name no longer appears in the city directories. Rudolph Palm, who worked for A. Zillian both as a barber and a porter, continued to own and live in the house until the mid-1920s. The house was then sold to Viola Bowman, who occupied it until its demolition ca. 1951.

\section{Archaeological Investigations}

A total of 1,377 artifacts was recovered from three mechanically excavated trenches and one hand excavated unit (Table 14-1). No time diagnostic artifacts were recovered. Bottle glass sherds $(n=415$, 30.14 percent of all recovered artifacts), animal bone fragments ( $\mathrm{n}=558,40.52$ percent), and construction artifacts/architectural debris ( $\mathrm{n}=287,20.84$ percent) constituted over 90 percent of all recovered artifacts. Sixty three extremely small sherds of ceramics (4.58 percent of all recovered artifacts) were also recovered. All the ceramics were either undecorated whitewares or undecorated semi-porcelain.

\section{Trench A Testing}

A $25 \mathrm{ft}$ east-west backhoe trench (Trench A) was excavated along the line of the front wall of the house foundation to examine the foundation materials and construction (Figure 14-1). A section of the limestone foundation, including the northwest corner, was exposed by the trench between 9 and 15 inches beneath the surface. Two in situ wooden posts were located in the trench. The posts were most likely supports for the frame porch depicted on fire insurance maps from the turn of the century (Sanborn Map 1904, 1911).

Only 26 artifacts were excavated from Trench A (representing 1.89 percent of all artifacts recovered from 41BX639) including 25 animal bone fragments and one nail (Table 14-1). 


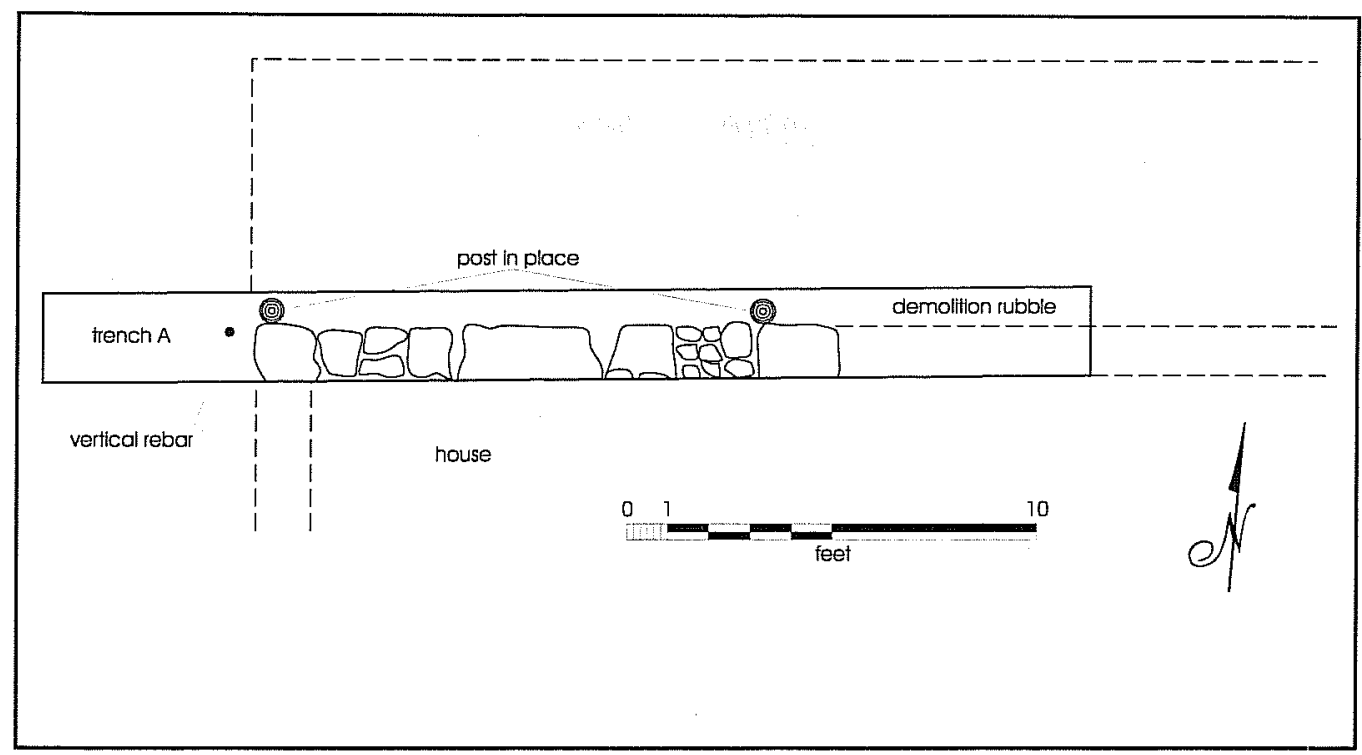

Figure 14-1. Trench over front wall of the Palm house.

Table 14-1. Artifacts from the Palm Site

\begin{tabular}{|c|c|c|c|c|c|c|c|c|c|c|c|c|}
\hline Unit/Sec & 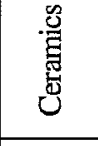 & $\frac{\sqrt[0]{3}}{3}$ & 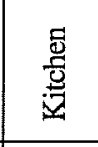 & 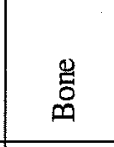 & 梠 & $\begin{array}{l}\text { 具 } \\
\text { 总 }\end{array}$ & $\begin{array}{c}\text { 쥼 } \\
\text { 员 } \\
\text { 岕 }\end{array}$ & 总 & 㖓 & 总 & 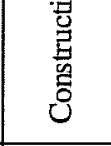 & Total \\
\hline Tr. A & 0 & 0 & 0 & 25 & 0 & 0 & 0 & 0 & 0 & 0 & 1 & 26 \\
\hline $\operatorname{Tr} . \mathrm{B} / 1$ & 19 & 45 & 0 & 17 & 0 & 1 & 0 & 0 & 0 & 0 & 0 & 82 \\
\hline $\operatorname{TrB} / 2$ & 2 & 14 & 0 & 0 & 0 & 1 & 0 & 1 & 0 & 0 & 8 & 26 \\
\hline $\mathrm{TrB} / 3$ & 5 & 35 & 0 & 33 & 1 & 2 & 0 & 0 & 0 & 0 & 16 & 92 \\
\hline $\operatorname{TrB} / 4$ & 2 & 19 & 0 & 0 & 0 & 2 & 0 & 0 & 0 & 0 & 11 & 34 \\
\hline $\mathrm{TrB} / 5$ & 0 & 0 & 0 & 0 & 0 & 0 & 0 & 0 & 0 & 0 & 0 & 0 \\
\hline $\mathrm{TrB} / 6$ & 8 & 34 & 1 & 37 & 1 & 1 & 0 & 1 & 0 & 0 & 18 & 101 \\
\hline $\mathrm{TrB} / 7$ & 1 & 2 & 0 & 0 & 0 & 0 & 0 & 0 & 0 & 0 & 7 & 10 \\
\hline $\mathrm{TrB} / 8$ & 1 & 4 & 0 & 6 & 0 & 7 & 0 & 0 & 0 & 0 & 19 & 37 \\
\hline $\operatorname{TrB} / 9$ & 0 & 0 & 0 & 0 & 0 & 0 & 0 & 0 & 0 & 0 & 0 & 0 \\
\hline $\operatorname{TrB} / 10$ & 0 & 15 & 0 & 3 & 0 & 0 & 0 & 0 & 0 & 0 & 59 & 77 \\
\hline $\operatorname{TrB} / 11$ & 4 & 16 & 0 & 4 & 0 & 0 & 0 & 0 & 0 & 0 & 5 & 29 \\
\hline $\operatorname{TrB} / 12$ & 6 & 11 & 0 & 58 & 0 & 2 & 0 & 0 & 1 & 0 & 80 & 158 \\
\hline $\begin{array}{c}\text { TrC } \\
\text { Unit A }\end{array}$ & 6 & 66 & 0 & 47 & 2 & 2 & 0 & 1 & 2 & 0 & 38 & 164 \\
\hline $\mathrm{TrCl} 1$ & 1 & 110 & 0 & 92 & 0 & 0 & 1 & 0 & 0 & 0 & 8 & 212 \\
\hline $\mathrm{TrC} / 2$ & 2 & 5 & 0 & 107 & 0 & 5 & 0 & 0 & 0 & 0 & 4 & 123 \\
\hline $\mathrm{TrC} / 3$ & 1 & 7 & 0 & 17 & 0 & 0 & 0 & 0 & 0 & 0 & 1 & 26 \\
\hline $\mathrm{TrC} / 4$ & 4 & 29 & 0 & 75 & 16 & 1 & 0 & 0 & 0 & 1 & 12 & 138 \\
\hline $\mathrm{TrCl} 5$ & 1 & 3 & 0 & 37 & 0 & 0 & 0 & 0 & 0 & 0 & 1 & 42 \\
\hline Total & 63 & 415 & 1 & 558 & 20 & 24 & 1 & 3 & 3 & 1 & 288 & 1377 \\
\hline $\begin{array}{l}\% \text { of } \\
\text { Total }\end{array}$ & $4.58 \%$ & $30.14 \%$ & $0.07 \%$ & $40.52 \%$ & $1.45 \%$ & $1.74 \%$ & $0.07 \%$ & $0.22 \%$ & $0.22 \%$ & $0.07 \%$ & $20.92 \%$ & \\
\hline
\end{tabular}




\section{Trenches B and C}

These trenches were excavated during the mitigation phase to locate backyard structures (Figure 13-1) and to record how they were built. We also hoped to recover additional artifactual evidence of the occupants of the site.

Early twentieth-century maps depicted an ironclad building behind the primary dwelling (Sanborn Map $1904,1911)$. The maps variously identified the building as an outhouse or outbuilding. After 1925, however, the structure was identified as a dwelling (identified on maps as 238 Blum Street). A $48 \mathrm{ft}$ northsouth backhoe trench (Trench B) was excavated through the entire length of this building to sterile soil (a maximum depth of 30 inches). Remnants of a limestone rubble foundation and three in situ cedar posts believed to have been associated with the structure were observed at $2 \mathrm{ft} 8$ inches, $10 \mathrm{ft}$, and 18 $\mathrm{ft}$ from the north end of the trench (Figure 14-2).

To maximize spatial control, Trench B was recorded in four foot units (Units 1 through 12). In general, four major soil changes were observed. In the upper portions of the trench, from the surface to nine in below
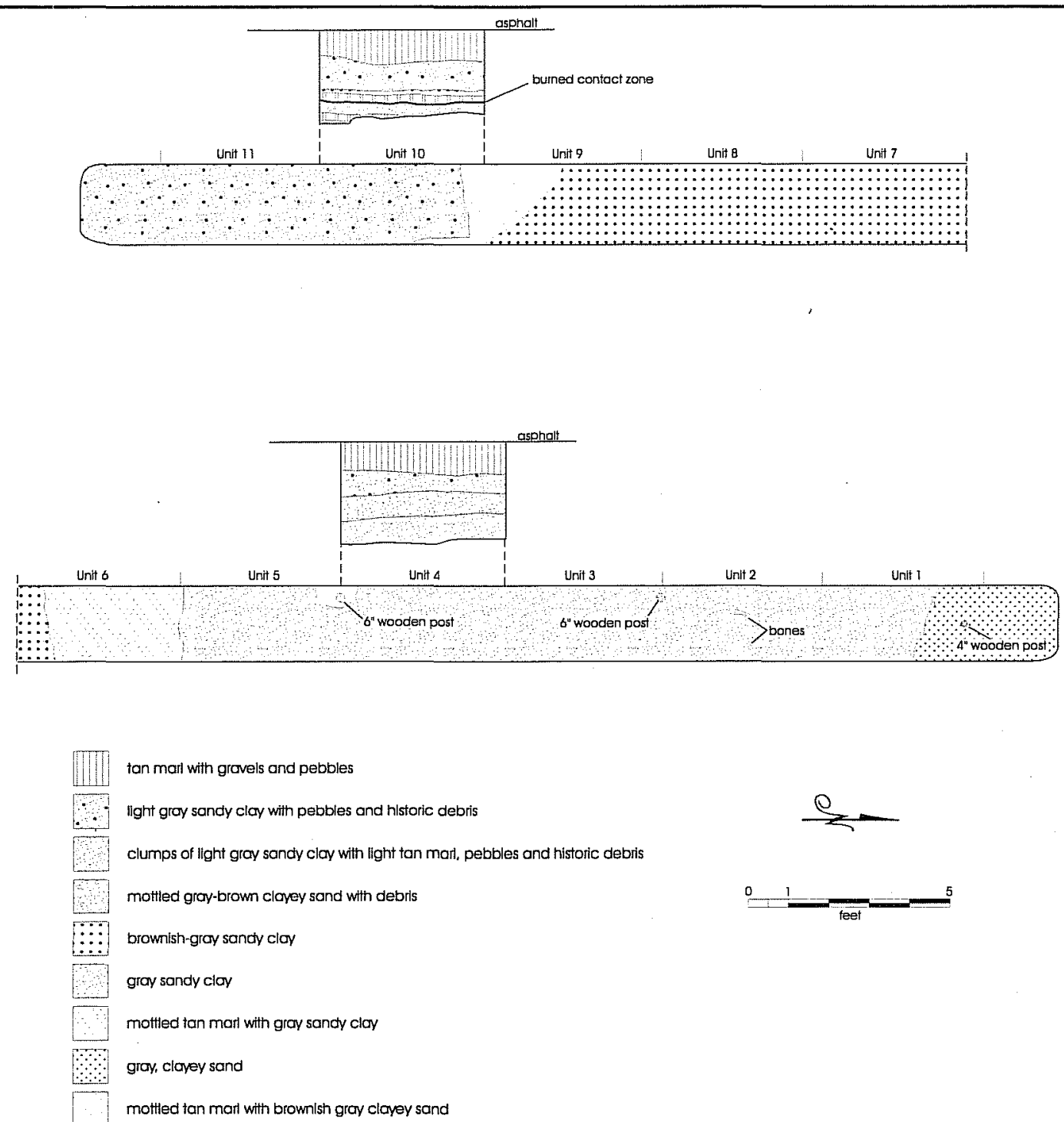

Figure 14-2. Trench $B$ across ironclad outbuilding. 
the surface, a tan marl layer with limestone pebbles and gravels was recorded. A light gray sandy clay layer was next observed from about 9 to 15 inches beneath the surface. Most of the artifacts were recovered from this layer. A variety of thin layers was found between this level and the sterile gray brown clayey sand at the bottom of the trench (Figure 14-2).

Approximately 646 artifacts (46.91 percent of all artifacts from 41BX639) were excavated from Trench B (Table 14-1). The total includes 222 construction/ architectural debris artifacts (77.35 percent of the construction artifacts recovered from the site), 158 animal bone fragments ( 28.31 percent), and 195 bottle glass sherds (46.99 percent). Forty-eight ironstone sherds (76.19 percent) were also recovered. Objects of particular interest included a clothing buckle, a silver teaspoon, and drinking glass fragments.

Backhoe $\operatorname{Tr}$ ch $\mathrm{C}$ was excavated north to south across what was bi ieved to be the remnants of a frame outbuilding, le shape of which suggested that it might be a privy. I te trench was approximately $10 \mathrm{ft}$ long and was excavated to a maximum depth of 52 inches beneath the surface. A shallow trash deposit found in the east profile of this trench was investigated with a hand-excavated 3-x-3-ft test unit (Unit A). Excluding Unit A, 541 artifacts were recovered from Trench C (39.29 percent off all artifacts). Three hundred twentyeight animal bone fragments (58.79 percent off the site's faunal assemblage), 154 bottle glass sherds (37.11 percent), and 26 construction artifacts $(9.06$ percent) were excavated from Trench C (Table 14-1).

Unit A was excavated to 34 inches beneath the surface (Figure 14-3). Four soil levels were identified based on observable differences in soil color and texture. Level 1 extended from the surface to nine inches beneath the surface. The level consisted of a hardpacked gray clay with unmodified chert cobbles. In the eastern portion of the level, from six to nine inches beneath the surface, a circular, hard-packed marl inclusion was observed. A hole in the center of the marl feature contained a dark black, soft silty clay with charcoal and ash. The significance of the feature was not determined. Level 2 was a thin layer of fine

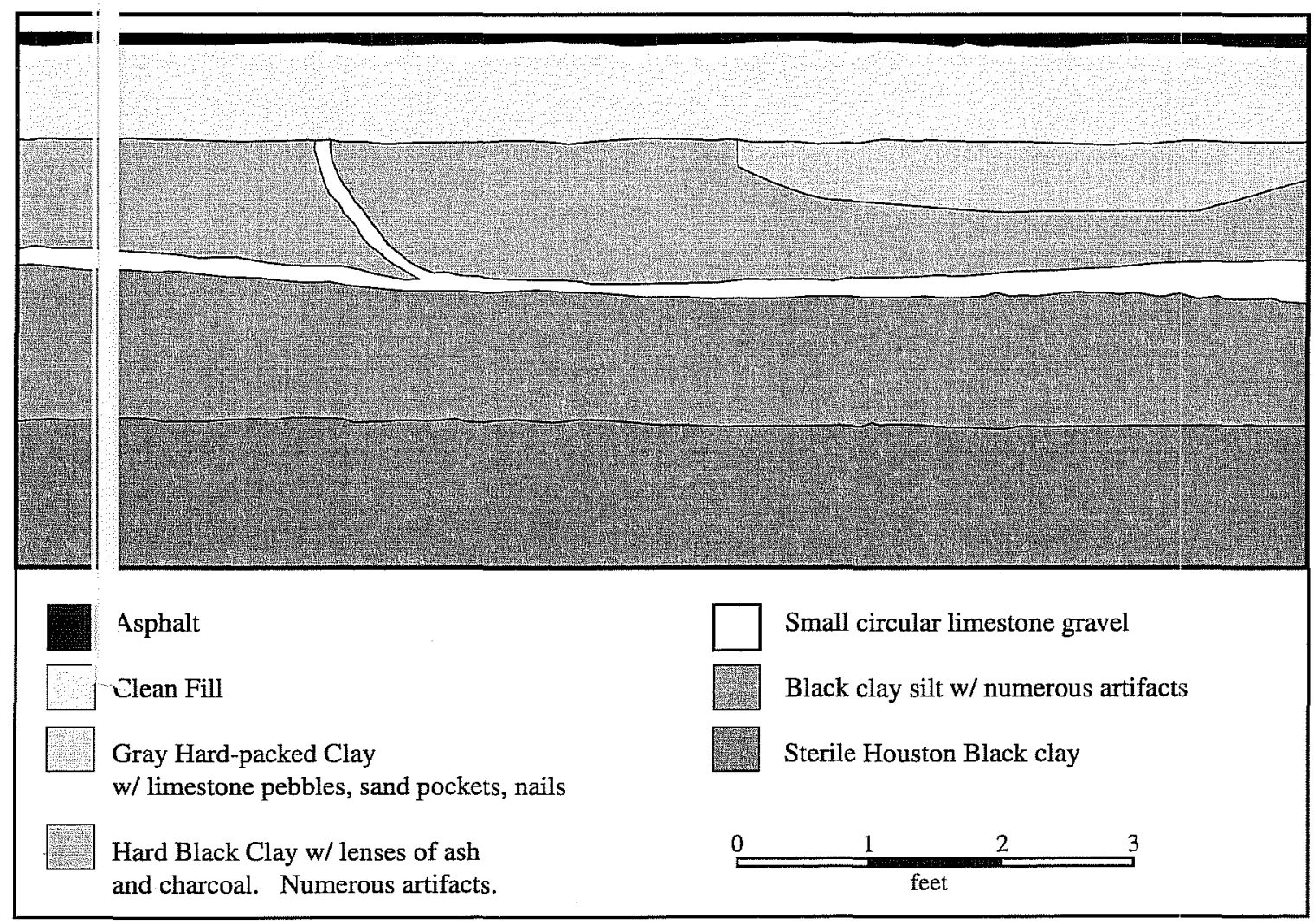

Figure 14-3. East profile of Unit A. 
grained, light-gray clay from 9 to 12 inches beneath the surface. Level 3 extended from 12 to 18 inches beneath the surface and consisted of chert and limestone gravels and (unmodified) cobbles. Level 4, from 18 to 36 beneath the surface, was Houston black clay. The entire was unit was excavated from 18 to 24.5 inches, but only the southwestern portion of the unit was excavated from 24.5 to 36 inches.

Unit A contained 164 artifacts representing 11.91 percent of all artifacts from 41BX639. Sixty-six bottle glass sherds (15.90 percent of the site's glass assemblage), 47 animal bone fragments ( 8.42 percent), and 38 construction artifacts (13.24 percent) were located in Unit A. The general shape of the intrusion and its lack of artifactual material argue against its use as a privy pit.

\section{Summary}

This site provided our first opportunity to examine an ironclad outbuilding that became a dwelling in later years. A trench through the length of this building (Trench $B$ ) revealed the fact that both cedar posts and rubble stone had been used in the construction. Also, it appeared that the only clue to the presence of an outbuilding in this area was the row of posts, which would make it next to impossible to identify this type of building unless it was indicated on a map.

A similar examination was done of another outbuilding on the opposite side of the yard (Trench C). Here, as in the Fischer yard, a shallow trash pit was discovered which once would have been beneath the building and probably preceded it. We were unable to tell whether there was any reason for these overlapping sites, other than the fact that San Antonians preferred to build outbuildings along the sides and back of their yards, leaving the center open. 


\title{
Chapter 15: Searching for the Funeral Pyre
}

\author{
Site Identification: The Funeral Pyre \\ Location: Block 1010, Front two-thirds of Lots 6 and 7
}

\section{Historical Background}

One of many unanswered questions about the famed siege of the Alamo in 1836 is the question as to the disposition of the bodies of the defenders. One of the earliest accounts of the treatment of the remains is contained in the diary of Lt. Colonel José Enrique de la Peña, an eyewitness with the victorious Mexican Army. "Death united in one place both friends and enemies; within a few hours a funeral pyre rendered into ashes those men who moments before had been so brave that in a blind fury they had unselfishly offered their lives and had met their ends in combat" (de la Peña 1975: 54-55). The alcalde of the conquered village, Antonio Ruiz, was assigned the distasteful task of disposing of the bodies by General Santa Anna. He confirmed that they were burned but mentions only one pyre and fails to pinpoint a location. In his statement recorded some 24 years after the battle, he related that Santa Anna had furnished a company of dragoons to bring wood and dry branches "about 3 o'clock in the afternoon they commenced laying the wood ... upon which a file of dead bodies was placed ... and in this manner they were all arranged in layers. Kindling wood was distributed through the pile and about 5 o'clock in the evening it was lighted" (The Texas Almanac for 1860: 80-81). Dr. James H. Barnard, who was spared the massacre at Goliad and transported to San Antonio to treat the injured Mexican soldiers, recorded in his diary that "we went to visit the ashes of those defenders of our country, a hundred rods [550 yards] from the fort or church to where they were burnt. The bodies had been reduced to cinders. Occasionally a bone of a leg or arm was seen almost entire" (de Zavala 1917:38-39).

Some months after Barnard visited the site of the pyre, Lt. Colonel Juan N. Seguin arrived to take possession of San Antonio for the newly organized Republic of Texas. On February 25, 1837, he gave the remains a formal military funeral as a sign of the respect with which they were held. In his description of the event, the ashes were found to be in three separate heaps. Ashes from the small site were placed within a coffin which contained a plaque bearing the names of Travis, Bowie, and Crockett. The coffin was carried across the San Antonio River to San Fernando church where it rested for a portion of the ceremony. From the church a procession bearing the remains "through the principal avenue of the city" recrossed the river to the "principal spot and place of interment, where the graves had been prepared." At that point full military honors were rendered and the "coffin and all of the ashes were interred." (Sibley 1966:272-280).

In 1843 William Bollaert, an Englishman in Texas attempting to gain a foothold into the lucrative land business, reported that he was conducted to the grave site "under some peach trees a short distance from the Alamo" (Bollaert 1956:222). A visit to a "peach orchard" was also noted by William McClintock in 1846 (McClintock 1930:145-146). In neither case is a direction or distance cited. This reference to the location of the pyres in a peach orchard may have arisen from a report, now generally discredited, by Doctor John Sutherland that the pyres had first been located by a Company of Rangers, under the command of Captain Byrd Lockhart. "These remains they gathered into a substantial coffin and interred them with military honors at a spot, then a peach orchard, not far from the scene of the last charge and struggle" (Sutherland 1911).

Reuben M. Potter, a Captain with the Quartermaster Corps of the Alamo in 1860, stated:

the place of burial was in what was then a peach orchard outside the town and a few hundred yards from the Alamo. It is now a large enclosed lot in the midst of the Alamo suburb, but fortunately not been built upon. The rude landmarks which once designated the place have long since 
disappeared, and it would require diligent search to find the exact locality. It is hoped that search will not be delayed til it is too late (Potter 1878:16).

Potter was unable to complete his search, for in 1861 , he became a prisoner of the Confederates who had captured the city and he was marched to the coast and deported. In 1878 he stated that the site " is now densely built over, and its identity irrecoverably lost. This is too sad for comment" (Potter 1878:21).

By the time the story was documented by the Hispanic savior of the Alamo, Adina De Zavala, in 1917, the number of pyres had grown to four. "Tradition says that this first funeral pyre was lighted in the courtyard, but that orders were given later to burn the rest of the bodies elsewhere, and that these pyres were then made beyond the walls. These three pyres were to the south, southeast and east by south" (De Zavala 1917:36). However, this would well have served her own purposes, for she held that the convento of the Alamo was far more important than the church structure favored by the opposing faction of the Daughters of the Republic of Texas, led by Clara Driscoll. Amelia Williams, in her study of the Alamo, states that this view was also supported by Mary Austin Holly in 1836 , but she fails to cite in which of her publications this information appears (Williams 1933:35).

Charles Merritt Barnes, a reporter for the San Antonio Express, in his history published in 1911, recounts the story as reported to him by eyewitnesses that he encountered.

He [Santa Anna] directed the Alcalde, Ruiz, to have built two immense wooden pyres. These were located on what was then known as the Alameda, or Cottonwood grove roadway. It is now a wide portion of East Commerce street. The northeastern end of one of these pyres extended into the eastern portion of the front yard of what is now the Ludlow House. The other pyre was in what is now the yard of Dr. Ferdinand Herff Sr.'s old Post, or Springfield House. I have had both pyres' positions positively located by those who saw the corpses of the slain placed there [Barnes 1910:36-37].
One of the individuals referred to was 90 -year-old Pablo Diaz, interviewed by Barnes four years prior to the publication of his book (Barnes 1906). The year following publication, Barnes wrote a follow up article for the newspaper, in which he expanded upon the information given in his widely read book.

Where workmen are excavating for the cellar of a new building that will stand on the spot of one of the two funeral pyres whereon the bodies of those slain in the Alamo's defense were consumed, is one of the memorable places of San Antonio, never marked and constantly passed unheeded. It will not be long before this spot and the one where the other funeral pyre was built will be the site of buildings for commercial purposes, and the populace, in all probability, will forget that either place was ever of historical interest.

He then proceeds to describe the site in great detail:

The spot where the cellar is being dug comprises one half of the area on which the first pyre mentioned was located. It is on the north side of East Commerce Street, adjoining the Ludlow House. The building is being constructed by Dr. G. H. Moody. The pyre occupied a space about ten feet in width by sixty in length, and extended from northwest to southeast from the property owned by Mrs. Ed Steves, on which the Ludlow House is built, to and through the property the Moody structure is to occupy, and a short distance into the street.

Next he describes the second pyre location: "the other pyre, which was of equal width, was about eighty feet long, and was laid out in the same direction, but was on the opposite side and on property now owned by Dr. Ferdinand Herff, Sr., about 250 yards southeast of the first pyre, this property being known as the site of the old Post House or Springfield House" (Barnes 1911). Barnes reveals that his informants were Diaz, Juan Antonio Chavez, and Enrique Esparza, ranging in age from 83 to 90 years.

Almost as an afterthought, Barnes adds that the same sites had been identified by Juan Antonio Chavez and August Biesenbach as the place where they had earlier 
gathered remains from the pyres. Biesenbach was quoted as attesting that they had removed "fragments of heads, skulls, arms and hands" and given them final burial at "Odd Fellow's Rest, on Powderhouse Hill" (Barnes 1911). He further testified that the remains had been placed between two tombs that were "monuments to people killed in tragic episodes which occurred some years after the struggle at the Alamo, and had no connection with it, but happened to have been buried for some time below the location of one of the pyres" (Barnes 1911). The "tombs" referred to in the Odd Fellows' cemetery off Commerce Street beside the City Cemeteries, are in fact two obelisk. marking the graves of Captains Richard Addison Gillespie and Samuel Hamilton Walker, legendary Texas Rangers killed during the Mexican War in 1846 and 1847 , respectively. Both had been returned to San Antonio for burial after the hostilities, but their grave sites had long been recognized and frequently honored during memorial ceremonies. However, a search of the City Council records reveals that in January of 1848 it was resolved by Council that the "remains of the late Capt. S. H. Walker should be interred by the side of the lamented Capt. R. A. Gillespie with civil and military honors," yet the place of burial is not specified (City Council Records [CCR], Office of the City Secretary, City Hall, San Antonio, Volume A:132, January 4, 1848). Some eight years later Alderman Smith submitted a resolution that "the citizens of San Antonio have permission to remove the remains of the late Captains Gillespie and Walker from the Alameda to the Odd Fellows Cemetery" (CCR, Volume B:415, April 18, 1856). The San Antonio Herald reported that the remains were removed "from beneath the cottonwood trees east of the river to the Odd Fellows cemetery" (San Antonio Herald [SAH], 26 April 1856:2). It would therefore appear that Biesenbach's statement of their burial in the pyre has credibility.

Since this resume is merely an account of a few of the various sites reputed to be the resting place of the remains of the participants, research seems to indicate that the only place that can safely be eliminated from contention is beneath the Cenotaph that stands in the middle of Alamo Plaza; ironically the place most tourists assume is the site of their burial. Yet the artist, Pompeo Coppini, clearly recognized that this was not the case, for the term is defined as "a monument for the dead whose bodies lie elsewhere." With the disturbance of the area around the battle site, an attempt to locate and excavate for the pyres is clearly futile. However, in view of the documentation that had been presented seemingly indicating that the area on both sides of East Commerce might be the last remaining opportunity to investigate for evidence of their existence, it became imperative that an attempt be made prior to the construction of Rivercenter Mall. The site on the south side of Commerce, the one indicated by Barnes as the "Post or Springfield House," had long been a landmark until it was destroyed by the river extension for HemisFair in 1967. Since this was prior to the enactment of the executive order creating the Antiquities Act, no archaeology was performed. With this in mind a careful attempt was launched to locate with as much accuracy as possible any portion of the area between the former sites of the Ludlow Hotel and the Moody Building that may not have been totally disturbed by construction in the ensuing 75 years since it was identified as a probable location.

\section{Ownership History of the Lots Along Commerce Street}

The entire parcel that would eventually become NCB 1010 was a portion of a grant by the Spanish Government to Luis Hernandez after the mission lands were secularized (Spanish Archives [SA], Office of the County Clerk, Bexar County Courthouse, San Antonio, Bexar County Archives Volume II:95, Volume III:95). The land remained in the hands of the family, basically undeveloped, until sold by the heirs to Edward Dwyer (BCDR Volume T2:79). Edward Dwyer, a native of Ireland, came to Texas early in the Republic period. He formed a partnership with William Elliott and established himself as a prominent businessman in the city. He married Mariana Leal, descendent of the original Canary Islanders and widow of Rosario Ramon, on July 18, 1843. In 1844-45 Dwyer served as mayor of San Antonio (Chabot 1937:152). Upon his death in 1854, his estate and considerable property passed to his widow. Mariana eventually transferred the property along the Alameda to their eldest child, Anita (BCDR 1:58,67,152). In 1859 Anita married the dashing West Point graduate 
John Withers. After his graduation from the Point in 1849, he served in Oregon and California and upon rising to the rank of captain was assigned to the adjutant general's department under General Twiggs in San Antonio. He also served as aide to Twiggs's successor, Colonel Robert E. Lee. After his marriage he was transferred to Washington as Adjutant General, but upon the start of the Civil War he resigned his commission to cast his fortune with the Confederacy. He served as a colonel on Lee's staff in Richmond, Virginia. After the war, he and Anita returned to San Antonio where he joined George Brackenridge in the banking business until his death in 1892 . They had three children, the eldest daughter became the wife of General John L. Bullis (Lewis Publishing Company 1907:317-319).

Shortly after their return to San Antonio after the war, John and Anita conveyed unimproved Lots 3, 4, 5, and 6 to John Kissling for \$2,000 (BCDR Volume U2:325). Johann Joseph Kissling had been born at Hessen-Cassel, Germany, in 1830 and, prior to 1850 , immigrated to Texas. Kissling received his naturalization papers on May 26, 1853 (United States Census Report [USCR] of 1850, Bexar County; Naturalization Records [NR], County Clerks Office, Bexar County Courthouse, San Antonio, Bexar County Archives, Book D:120). Kissling, a builder and stone mason, constructed his homestead on Lots 3 and 4, which he occupied until 1884 . Lots 5 and 6 remained undeveloped and, in 1874, were transferred to Edward Steves "for lumber storage"(BCDR Volume 4:42). Edward Steves had been born in Barmen, Elberfeld, Germany, on December 14, 1829, and immigrated to New Braunfels in 1848 where he married Johanna Kloepper in December of 1857 . The couple moved to San Antonio in 1866 where Ed established one of the first lumberyards in the city on the corner of Blum and Bonham streets (Chabot 1937:399). The business was extremely successful and was later relocated further out Commerce Street near the Southern Pacific depot. He apparently utilized the lots merely for storage and sold the unimproved lots to Daniel Ludlow just after the turn of the century. Ludlow then constructed a three-story red brick boarding house on Lot 5 and the eastern half of Lot 6 . The hotel was later known as the New Commerce Hotel, managed by Mrs Emily Blumenthal (CDs 1902-1903, 1912). The building was razed in 1938 when it became a commercial automobile parking lot (CD 1939).

The two lots located directly to the east on Commerce Street, Lots 7 and 8, remained in a unimproved state when they were conveyed by John and Anita Withers to Edward Bennett in March of 1883 for $\$ 2,000$ (BCDR 27:98). The lots were then transferred on speculation until 1907 when they were purchased for $\$ 4,500$ by Dr. George H. Moody (BCDR 114:601). Moody received his medical degree from Tulane University in 1896 and became an assistant to Dr. Marvin L. Graves, director of the Southwest Texas Hospital for the Insane. In 1903 he established the Moody Sanitarium, specializing in nervous and mental disorders. He was elected president of the Texas State Medical Association in 1915 (Nixon 1936:244). In 1910 he contracted for construction of a three-story brick building on the eastern portion of the lots; this is the structure that is under construction in 1911 as noted by Barnes. By 1912 the building was the Geneva Apartments, under the management of Mrs. D. A. Head (City Directory 1912). By 1939 the building housed the Salvation Army (City Directory 1939).

\section{Archaeological Investigations}

After preliminary research revealed that the area held a high probability of containing the remains of one of the legendary lost funeral pyres from the battle of the Alamo, it was obvious that all possible precautions must be taken to insure that the site was carefully examined and excavated with the utmost care. It was first necessary to locate the exact area specified by Barnes as the area containing the pyre, and then an estimation was required to evaluate the effects of subsequent disturbances by later construction on the site.

The research by Barnes clearly indicated that both extremes of the site had already been eliminated by the construction of basements for the Ludlow Hotel and the Moody Building. This left only the portion between the two structures holding any promise of remains of the final repository of the ashes of the defenders of the battle. Since Barnes had first conducted his research, almost 75 years of 
development in the heart of the city had occurred; therefore, it was necessary to undertake a detailed search of the records to ascertain what structures may have been built over the area, and the nature of their construction to determine if the original surface may have survived. The most valuable sources proved to be the Sanborn Insurance maps. These color-coded maps of the insurable portions of the city give a wealth of information concerning the placement of the structures on the lot, the nature of their construction, and the presence or absence of basements. These maps are available for selected sections of San Antonio beginning in 1887 . The early maps corroborate that there was no activity on any of the subject lots until the construction of the Ludlow building in ca. 1901.

The Sanborn Map of 1904 indicates the presence of a three-story brick boarding house, with a basement, occupying most of Lot 5 and the western half of Lot 6 , with a one-story brick outhouse extending across the rear portion of the lots. The area of Lots 7 and 8 is still undeveloped at that time; the Moody Building was not constructed for another decade.

The Sanborn Map of 1912 shows the Moody Building as a three-story apartment building, with basement, constructed on the eastern portion of Lots 7 and 8, with a one-story frame building adjacent to the west. The Ludlow apartments are vacant but basically unchanged, but the brick outbuilding has been razed, probably indicating the introduction of indoor plumbing.

By 1952 the maps show the lots under consideration as unchanged, but the lots to the east (Lots 3 and 4) have been converted to parking for the Joske's department store on Alamo Plaza. By 1957 the Ludlow Hotel and the frame building had been razed in preparation for the construction of a tire outlet for Joske's. The Moody building contained eight separate apartments and the rear of the building housed the Lone Star Printing Company (City Directory 1958). The Joske's Tire Care Center was completed by 1959 and consisted of a reinforced steel and concrete showroom on the corner of Bonham and Commerce streets, with a service bay and grease pit on Lot 6 . In 1971 the Moody Building, then Lone Star Apartments and Bexar Chemical Company, were purchased by the Joske Corporation and razed for an additional service bay for the tire store and further expansion of the parking lot (CDs 1972, 1973).

Prior to beginning excavation, the area was measured and the original lots lines were reestablished. The interior lots still retained their original width with only the depth altered to a minor extent by slight widening of Commerce Street. However, the lots along Bonham and Bowie streets had been greatly reduced by considerable widening of both lanes. It was therefore necessary to establish several base points for measurement from what appeared to be the corners of lots that evidenced the original lot limits. Once the original lines of Lots 5 through 8 had been established and verified the area could be assessed for potential areas that may have retained their character without excessive construction disturbance. Lots 5,6 , and 50 $\mathrm{ft}$ of Lot 7 were occupied by the structure that served as Joske's tire outlet and automobile service facility, with the remaining $20 \mathrm{ft}$ covered with an asphalt service driveway. The area that had been the Moody Building, destroyed a decade previously, had its basement filled and the surface paved over for additional parking. Demolition of the tire store began the last week of November 1984, with site clearance completed by the end of the year.

On January 7, 1985, the foundation of the Ludlow house was cleared and the area to the east measured for the establishment of the grid system. The following day the area to be excavated, approximately 175 square meters, was divided into $423 \times 3-\mathrm{m}$ units marked by string lines. The area fronting along the sidewalk along Commerce Street and bordering the foundation of the Ludlow Building was divided into 50 additional one meter units. Two backhoe trenches were excavated to below sterile soil along the east and south sides of the structure; the first trench, $2.5 \mathrm{~m}$ in length, was placed one meter south of the front of the building. The second trench, $3.5 \mathrm{~m}$ in length, was placed $3.5 \mathrm{~m}$ away from and parallel to the eastern wall. Excavation units were then opened in a checkerboard manner, varying slightly as evidence of disturbance dictated. The units were excavated by natural levels and all excavated material was passed through $1 / 4$-inch screens. All artifacts were bagged by unit and level. Twenty-seven one-meter controlled units were excavated to sterile soil with the operation terminated on March 1, 1985. 
All skeletal remains from these excavations were submitted to a physical anthropologist at the Southwest Foundation for Biomedical Research for identification. Visual observation of the 847 recovered specimens found that none of these remains could be identified as human (see Appendix D). After further laboratory work, an additional 245 bone fragments were submitted for examination; none of which were identified as being human remains (Appendix D). None of these bones displayed evidence of burning, and no concentrations of ash and/or charcoal were found during the excavations.
As a result of the excavations, it appears that either all traces of the funeral pyres have been entirely eliminated by activity on the site during the five decades since the burning of the remains or that this was not actually the scene of the event. This possibility was recognized during the planning stages of the project but it was decided that an effort to fully investigate the site were necessary to eliminate any possibility of the destruction of an historical site of the utmost importance. 


\title{
Chapter 16: Moving the Fairmount Hotel
}

\author{
Site Identification: The Fairmount Hotel; NCB 1010, Lots 24 \& 25 \\ Address: 355-359 East Commerce St.
}

\section{Historical Background}

The three-story Italianate Victorian Fairmount Hotel (Figure 13-1), designed by local architect Leo M. J. Dielman, was built at the corner of Commerce and Bowie Streets for Mrs. Veronica Felix. Her husband, Theodore, had planned the hotel in that location because of its proximity to the railroad station to the east. When he died in 1903, his wife carried on his dream and supervised the hotel's construction, continuing to run the hotel herself for a number of years (SAE April 7, 1985). Ownership of the Fairmount later was transferred to the George C. Sauer family, then the Julius Kelfer family, and finally to Joske's. The City Directories show the hotel as occupied from 1909 through 1948, then vacant in directories after 1960. The commercial space on the main floor was occupied by Cut-Rate Furniture in 1918. In 1927 it was the location of the San Antonio News Agency. Kelfer Furniture occupied the building from 1938 through 1960 (Markey 1981:19).

\section{Moving the Hotel}

Four years prior to the planning of Rivercenter Mall, Joske's department store had proposed the destruction of the Fairmount for an 11-acre expansion to the east. This action was derailed when the Historic Review Board denied the developers a demolition permit, but the following July the city council overturned the denial. The following year the San Antonio Conservation Society protested the destruction of the structure and supported instead the relocation of the building or, at the least, the incorporation of the historic façade into any future development on the site ( $S A E$ April 7, 1985).

The Edward J. De Bartolo Corporation of Youngstown, Ohio, a major player in the projected development, commissioned the firm of De Lara-Almond, Architects to investigate the feasibility of relocating the structure. The architects determined that the relocation of the façade alone was difficult structurally and would leave the remaining structure severely weakened, and therefore was not recommended. However, the relocation of the entire building was possible, and cost effective if a site adjacent to development was selected, the major impediment being the crossing of major thoroughfares. They estimated the cost at $\$ 250,000$ excluding permits and demolition of adjacent structures.

City historic preservation officer Pat Osborne and the San Antonio Conservation Society, having already led a battle to preserve the hotel for over three years, now began negotiations with the developers to have the structure moved a block west on Commerce Street and incorporated into the mall overlooking the new river extension. The developers-a consortium of Williams Realty Corporation, Edward J. De Bartolo, and Allied Stores, the parent company of Joske's-rejected that proposal on the grounds that it did not blend in with the overall scheme of the shopping center. Next, a site on the opposite side of Commerce Street on City Water Board property was offered for the relocation, but again the developers rejected this solution on the grounds that it would have required them to construct a parking garage to replace lost parking spaces (Richelieu 1985a).

As the fate of the old structure seemed sealed, new investors appeared on the scene: developers Benton K. Johnson, C. Thomas Wright, and Virginia Van Steenberg announced their interest in relocating the structure to city-owned property at the corner of Nueva and Alamo streets. The proposed 13,500 square-foot site had been cleared of a gas station and two other buildings for HemisFair '68 (Griffin 1985). The problem now became one of finding a company capable of moving such a massive brick building through four blocks of downtown, over the river and the turning of three corners prior to backing it onto 
the new location. All authorities contacted agreed on one firm, Emmert International of Portland, Oregon, which had recently moved the historic brick Southern Pacific Depot in Corvallis, Oregon, weighing 450 tons. This project would require lifting and moving a total weight of 1,600 tons, 3.2 million pounds, the "heaviest structure ever to be moved on wheels" (Richelieu 1985a).

On February 7, 1985, crews from M\&M Contracting began demolition on the support building at the location on Commerce street and had the site prepared within a week. On February 13, the project director for Emmert International, Rusty Gorman, arrived in San Antonio, and two days later his crews began preparation of the basement of the building. The job entailed cutting the structure at the basement level and inserting three layers of steel girders under the threestory brick hotel. These consisted of 19 double I beams forming the "cross steel," resting upon two triple Ibeam "mains" installed at right angles, and all that atop nine double I-beam "rockers." This massive weight would rest upon, and be transported on 36 Emmert's patented hydraulic dolly jacks, each valued at between $\$ 30,000$ to $\$ 35,000$. The 288 tires of these jacks would spread the weight of their burden on the pavement. The entire upper portion of the structure was encased in a 6-inch steel box beam cage secured with adjusting cables and steel strapping tape (Richelieu 1985b).

As this work was in progress, site preparation for the construction of the new basement on Alamo Street was started on February 16. Research had indicated that remains of the nineteenth-century Canterbury house might be encountered on the lots; therefore, it was agreed by all parties that the soil would be stripped from the site to look for traces of this structure or other features of interest. As the bulldozers began to clear away the surface of the lot, CAR archaeologist Joe Labadie detected artifacts indicating that the lot possibly held an important historic site. All work immediately stopped until the limits of the site could be determined. At approximately one meter below the street level, a linear ashen feature was exposed and construction activity in the area was terminated. The archaeologist established an area of approximately 7 $\mathrm{x} 11 \mathrm{~m}$ to be intensely shovel tested. The tests revealed a high potential for a feature predating 1850 . A $77-\mathrm{m}^{2}$ area of the site was established and bulldozing action eventually created a pedestal of earth which rose two meters above the final excavated surface. CAR then conducted controlled excavations over this entire area, using all available staff and a large number of volunteers from local archaeological organizations. These people, expending 1,300 person-hours, excavated 29 units in the period from February 20 to March 1. On March 6, 1985, at ceremonies commemorating the 149th anniversary of the battle of the Alamo, it was announced that the excavations had revealed a part of the earthworks for a military position used by General Santa Anna's soldiers during the siege of the Alamo in 1836 (Labadie 1986:1-6).

To add to the apprehension of the developers, who face an extremely limited time window for the anticipated arrival of the hotel, they received word the first week of February that a temporary restraining order had been issued against the use of the location for the hotel. The owners of the Four Seasons Hotel, now the Plaza San Antonio, claimed that the site had been leased for their use by the city since 1978. They further objected on the grounds that the hotel would eliminate open space in the vicinity of La Villita. The executive director of the San Antonio Development Agency, M. Winston Martin, countered that a parking lot was not the best use of urban open space because it was not "a people place" and that the hotel would contribute more life into the shops and businesses of La Villita (SAE, February 8, 1985, February 13, 1985). The issue was rendered moot when, on March 20, District Judge James Onion granted a continuance until June 30 for the trial, allowing time for the hotel move and renovation to take place (SAE, March 23, 1985).

This was not the only legal restriction that the relocator faced. The first had been the Urban Renewal Plan restrictions requiring a 20,000-square foot minimum lot size for any hotel site; but, since the 13,400-squarefoot Fairmount property was planned to be an ultraexclusive small hotel with valet parking, an approval of variances was readily awarded. These vexing problems had no effect upon the preparation of the structure for the task of transporting through the city streets. A spiderweb of cables inside the building insured structural integrity, and each opening was braced and shored with lumber (Engel 1985). 
On March 20 the first critical step on the actual move was accomplished, as the hotel was lifted off of its foundation approximately four inches. Thus began the gradual process, about one foot a day, raising the building to a height of eight feet above ground level allowing the tandem-wheeled hydraulic jacks to be installed. The project was heralded as "the heaviest building ever moved on wheels," qualifying it for an entry in the Guiness Book of Records (SAE, August $6,1985)$.

Finally, on March 29, the building was ready for its long-awaited and highly reported move to begin. At 2:30 P.M., Roman Catholic Auxiliary Bishop Bernard Popp blessed the hotel prior to its move into Commerce Street the next morning, while the city completed its final tasks of removing light fixtures, traffic signals, median planting and rerouting traffic away from the route of the structure. The route required the structure to move about five blocks, through two sweeping turns and a 90-degree pivot on its axis to align it on the new site. The cost of the renovation was estimated at $\$ 4$ million, with the move alone accounting for $\$ 650,000$. Saturday, March 30, a battery of eight huge trucks, their beds loaded with sand for additional traction, slowly moved the building into the intersection of Commerce and Bowie streets. The first-day efforts located the hotel at the intersection of Bowie and Market streets.

On Sunday, March 31, the Conservation Society and Mayor Henry Cisneros invited the city council, key staff members, and other guests to "A Moving
Experience" to be held in the Marina Garage, just south of the hotel's old location, as they watched the hotel turn its first corner and head west on Market Street. The move was halted at the Market Street bridge over the river extension to check the shoring under the bridge to insure it was able to bear the 3.2-millionpound load. Work crews had placed full bottles of beer between the shoring and the street surface to test the stress applied. Mayor Cisneros commented, "we've always wanted more hotels on the river, we may end up with a hotel in the river if this move does not go well" (SAE, 7 April 1985). The structure passed over the bridge without a broken bottle. At the end of the second day the Fairmount developers invited selected guests to a catered party "Somewhere on Market Street at the Fairmount Hotel." There, in the street in front of the Convention Center, the host unveiled a huge cake in the form of the hotel to honor the president of Emment International on his 70th birthday. On the third day, the hotel turned the corner onto Alamo Street and slowly progressed the final distance to the intersection of Nueva street. The hotel was then maneuvered onto HemisFair ground where it was slowly rotated in order to back it into its new site. It rested there, some 12 feet in the air, as the Emment crew took a short vacation while site preparation was completed. Finally, on May 9, the Fairmount was settled onto its new foundation as the final restoration and additional room construction were accomplished ( $S A E$, May 10, 1985). The Fairmount was opened for business the first week of September, with 17 suites and 20 rooms, with a price range of between $\$ 105$ to $\$ 375$ per night ( $S A E$, August 6, 1985). 


\section{Part III: Conclusions}

\section{Contents}

Chapter 17 : Summary and Conclusions 


\section{Chapter 17: Summary and Conclusions}

The Rivercenter Mall Project included extensive research, testing, and mitigative excavation. Selection of sites to be studied involved examination of city directories and U.S. Census Reports to identify the ethnicity and occupations of the people living in the project area. From this information plus a study of Sanborn Insurance Maps of 1888, 1892, 1896, 1904, 1912 , 1925, and 1952, sites were chosen as representative of various groups and differing types and dates of construction (Chapter 3).

The testing phase of the work included assessment of the accuracy of the insurance maps, careful observation of the various methods of construction, and location of subsurface features which should contain artifacts connected with the residents of the sites. Mitigation concentrated on these features to obtain as complete a record as possible of how people were living, what they were eating, and what was available in local stores at the turn of the century. We also hoped to determine ethnic differences in artifact collections since many of the people who first settled in the project area had come directly from their countries of birth.

One of the challenges of conducting this project was to record how the area related to San Antonio. In his historic background, Cox traced the relationship of the project area to the surrounding city as it changed from being irrigated farmland for Mission Valero, to one of the first suburbs as new German settlers arrived, to an area of various ethnic backgrounds as the lots were developed.

Starting with a few scattered houses, a small brewery, and one or two strategically placed commercial buildings, it was not many years until this area had completely filled with small residences occupied by people of various ethnicities and social and cultural backgrounds, from cartmen and masons to a bookstore proprietor and a brewer. As the adobes began to deteriorate, they were gradually turned into places of business or rental housing units or were replaced by large brick hotels, boardinghouses, and commercial buildings. With the coming of the automobile, the majority of the inhabitants moved out of the neighborhood and house lots were cleared to make parking lots. These served the commercial establishments which were building up in nearby city areas such as Alamo Plaza and Commerce Street.

By the time of the construction of Rivercenter Mall, all of NCB 166 had been cleared and paved for parking for Joske's Department Store, the structure of which is now a part of the mall. Block 1010 facing on Commerce Street was also totally commercialized. Excavation for the mall completely removed the entire project area to a depth of approximately $28 \mathrm{ft}$.

\section{Research Questions}

The research question approved by the Advisory Council in 1985 can now be addressed with the knowledge acquired during the various phases of the project.

1. Are discernable differences in social status, ethnic background, and economic status reflected in the archaeological remains?

Comparative analyses were conducted on artifacts from the various privies within the project area to accertain if discernable differences in socio-economic status or ethnicity were present. Initial emphasis was placed on identifying temporally diagnostic artifacts and relating them to former occupants. Once these temporal units were defined, we felt that quantitave analysis could reveal evidence of socioeconomic status, ethnicity, or gender.

However, as noted throughout this report and under research question No. 8 below, the artifact-bearing deposits in this study are not temporally stratified but are vertically mixed, homogenous accumulations. Although the history of many of the residences begins in the 1850 s, the privy and well deposits date to the time period between the late 1880 s, when privy- 
cleaning ordinances were passed, to the early 1900 s, when city sewer and water service became the norm.

Even within this later bracket of time, differences in ethnic background, socio-economic status, or gender were not reflected in the artifacts, although some differences (discussed below) were observed in architectural styles.

Ethnic background did not appear to be reflected in the artifacts or the architecture. Both were related more to the time period in which they originated and the family's resources, than to their ethnicity.

2. What was the structural evolution in this neighborhood through time?

The first houses and commercial structures were built of cut limestone or a type of soft limestone known locally as "adobe." Foundations for these buildings were made of a harder limestone which had been cut into blocks and laid with sand or sand and lime mortar. After the railroad arrived in 1877 , lumber became available for inexpensive house construction, such as the rental units on the Fischer lot which replaced the earlier adobe house in the 1890 s. Foundation for such construction was a pattern of cedar posts, as recorded on the Fischer site. Cedar posts were also used to support the frame porches on adobe and stone houses. Soon after 1900, the availability of brick led to the construction of several hotels and boarding houses within the project area, of which the Ludlow House is an example.

3. What differences exist in the artifacts between residential and commercial sites?

Except for the Faska site, differences often are not obvious enough to make a decision about a deposit based on artifact content. Perhaps this is because the commercial buildings investigated nearly all had residential use at some point in their history, resulting in mixed commercial and residential deposits.

4. What historical or archival sources link the structures to their owners?
City Directories, deed records, death records, court records, newspaper articles, and obituaries were all used to determine who built the various structures and who lived there. Family histories and oral history interviews helped to detail events associated with individual sites and what went on in the general neighborhood.

5. Are there records associated with the structures that would enhance their historical significance?

While all the buildings in the area were important to the individual families involved, none were determined from archival records to be particularly significant from an historical point of view, except for the Degen Brewery. The particular charm and value of the project area lay in its existence as a typical nineteenth-century San Antonio residential neighborhood, demonstrating the gradual evolution from residential to commercial to parking lot use.

6. What support features (wells, cisterns, privies, etc.) are present and how do they reflect cultural patterns?

Only one well was excavated during this project, although several were determined to be present on lots not included in the testing phase (Table 17-1). However, it was apparent that not everyone had a well. This appears to be true throughout the downtown area, to judge from the earliest Sanborn Insurance maps. It does appear that everyone had a privy, and that the

Table 17-1. Mitigated Features

\begin{tabular}{|l|c|c|c|c|}
\hline \multirow{2}{*}{ Site } & \multicolumn{5}{c|}{ Feature Types } \\
\cline { 2 - 5 } & Well & Privy (stone) & Privy (brick) & Trash Pit \\
\hline Degen & & $\mathrm{X}$ & & \\
\hline Tengg & & & $\mathrm{X}$ & \\
\hline Vanderstratten & $\mathrm{X}$ & $\mathrm{X}$ & & \\
\hline Mueller & & $\mathrm{X}$ & & $\mathrm{X}$ \\
\hline Fischer & & & & $\mathrm{X}$ \\
\hline Palm & & & & \\
\hline Faska & & $\mathrm{X}$ & & \\
\hline Battaglia & & & $\mathrm{X}$ & \\
\hline Kissling & & & $\mathrm{X}$ & \\
\hline Moody & & & $\mathrm{X}$ & \\
\hline
\end{tabular}


privy pits were lined either with stone (Degen, Mueller, Vanderstratten, Faska) or with brick. The difference may indicate whether they were built just before or just after the arrival of the railroad in 1877 .

Subterranean cisterns did not appear on sites in the project, except for one rumored to be in the back yard of the Tengg house. This need not mean that cisterns were not in use, but simply that they were above ground, possibly made of wood. Cultural patterns reflected are those of the entire town at this period, to judge by similar results obtained by the Alamodome project (Gross and Mendez 1997:243-257) several blocks to the southeast of this project.

7. Can structure placement within the lots predict locations for future excavations?

The placement of structures on nineteenth-century lots appears to be quite predictable. Houses were small when first built, with the anticipation that as a family grew they could be expanded, either with a second story as at the Tengg house, or toward the back of the lot. Service structures such as wash houses, storage sheds, and chicken coops, tended to be grouped at the back or sides of the lot, with the privy most likely near the back lot line, leaving the central yard free for a garden.

Houses were generally centered on the lot with a small front yard (10-15 ft deep) between the house and the street. However, two families actually appear to have thought ahead enough to leave room beside the original house for a later additional house to be used for rental income. Test trenches parallel to the front and back lot lines were successful in locating house foundations and backyard outbuilding sites during this project.

8. What diagnostic artifacts are present and what periods are represented?

The majority of the artifacts from the fill of the well and most of the privies date to about the time the features were abandoned. Since a local ordinance dictated that privies be cleaned out regularly, there were few if any stratified privy deposits such as have been found in earlier sites elsewhere (Noël Hume 1969:139-141). The abandonment of privies corresponds with the gradual acceptance by the residents of piped-in water and the attachment to the sewer line. Although there was a sewer main in Commerce Street as early as 1866 (CCM C:537), lot owners were very slow to hook up to it, due partly to the general conservative attitude in the city at the time, but perhaps more importantly due to the expense of adding a bathroom to the house and installing plumbing. There was a water line into the area by 1879 , but only 565 San Antonio residents had piped-in water in 1880 (Mayer 1976:650), indicating the community's slow acceptance of the need for it.

It appears that the wells may have been capped with boards or cedar logs when the water system was tapped for the house, then filled later at the pleasure of the occupant of the house, perhaps during a housecleaning effort. Empty wells that have never been filled are occasionally found by construction crews in downtown San Antonio. They are usually covered with boards and soil and forgotten until they are encountered during construction, or the boards collapse and reveal a deep hole in someone's yard.

Time periods represented by the artifact collections from the project include the 1850s through the 1940s, with the preponderance of the artifacts dating from the 1880 s to the early 1900 s. This time period has not up to now been very intensely examined in this part of the state, where the emphasis has been on the Spanish colonial period and the years leading up to the Civil War. Therefore, the opportunity to study artifacts from this time period has been particularly valuable for future research. Artifacts most valuable for dating purposes have been ceramics, especially those with maker's marks, and glass bottles either bearing embossed labels or datable evidence of manufacturing changes.

9. What cultural activities can be inferred from the results of this project?

A number of things can be surmised about families from examination of the trash discarded in privies and wells and on the surface of the yards. For instance, relatively large percentages of sherds from stoneware jugs, crocks, and churns suggest that a family carried on German traditions in preparing and storing food which necessitated the use of such vessels. The custom 
of families living on the second floor over a commercial establishment resulted in a mixture of discards from both types of operation. When such a mixture is encountered, we can surmise that at that time people still found it necessary to live within walking distance of their place of work because public transportation was probably not yet available. The presence and longevity of the Degen Brewery and the popularity of the place as reflected in the oral histories collected demonstrate the importance of that bar and beer garden in neighborhood life. The majority of the artifacts recovered reflect the activities of ordinary, lower middle class families going about their daily lives - an unusual number of medicine bottles suggesting an illness, the presence or absence of various children's toys telling about the makeup of the family, the predominance of inexpensive ceramics showing the lack of extra money for the finer things.

10. What information can be retrieved from the acequia laterals within the area?

When the project was planned, we anticipated finding traces of the laterals of the Alamo acequia, which irrigated this area when it was farmed in the eighteenth century. Early maps of the area indicated that these served to delimit the lot patterns between the north and south halves of Block 166, and between Blocks 152 and 1010. However, several backhoe trenches across their plotted locations showed no soil changes in these areas. This suggests that these were only shallow ditches that over time were obliterated by the effects of weather and man's later activities.

\section{Architectural Questions}

In the introduction we remarked on the fact that previous projects had suggested it would be useful to be able to recognize types of foundation construction used in various time periods and the building materials popularly selected. Similar information has been accumulated and studied in regard to local Spanish colonial sites (Fox 1990) and has been found most helpful in interpreting sites of that period.

It was apparent that this sort of information would aid us in future archaeological projects by:
1) helping in planning excavations on sites where we have information about what the original house looked like, such as the Degen and Tengg houses,

2) identifying and dating unexpected foundations revealed during excavations, a problem often encountered in urban sites,

3) understanding what we find on sites that have multiple occupations and a number of successive structures built on them, as in the case of the Fischer site.

We also anticipated learning how 19th century San Antonio home builders chose the materials from which they constructed houses of the common citizens. Drawings and photographs are available, but they show the surfaces of walls and roofs, not the materials behind and beneath them and how they are put together.

We also needed to know what to expect of archaeological sites buried beneath paved parking lots and how much disturbance to expect. Is there any hope of finding the original ground surface intact? Did the demolition of structures involve the misalignment and/ or the removal of foundations?

Because of our urgent need to answer these questions, we planned during the first testing phase of the project to examine in detail the construction methods and materials used. Test trenches were laid out so as to reveal foundations of known houses wherever possible in order to record materials and how they were used in construction.

\section{Available Building Materials}

Until the arrival of the railroad in 1877 , structures in San Antonio were built of the materials that were locally available-wood from native trees and limestone and sandstone exposed in the banks of streams. The builders of the earliest Spanish colonial houses made walls of logs set upright in the ground. These were interwoven with vines and brush to make solid walls upon which mud was smeared to create a weatherproof structure called a jacal. With frequent maintenance, a jacal could be made to last a number 
of years and was easy to replace or rebuild elsewhere as necessary.

Adobe bricks were also occasionally used, but mainly for interior partitions, since a soft, easily obtained limestone was readily available which required less effort to maintain than adobe. At mid-century an influx of Europeans who were accustomed to cut-stone houses brought about a rapid change in the appearance of the town. Caliche block houses with shingled roofs soon took the place of jacals.

By mid-century, when the first houses in the Rivercenter area were built, soft limestone or caliche block had become the universal material of choice. European stonemasons sought out deposits of various types of limestone which met their requirements, soft rock for walls of houses, harder limestone for foundations, and an even denser rock with which they had been accustomed to working in Europe for public buildings. The following description from the 1879 1880 San Antonio City Directory (1879:57) is helpful in understanding the thinking of the citizens at that time:

The soft magnesium lime stone, found on Powder House Hill, east of the city, is a very cheap material, and, when used for walls above ground, durable and very easily worked, as it can readily be sawed with an ordinary hand saw, and of this is built the majority of the fine buildings in the city. The Salado quarry, situated about six miles north of the city, furnished a rock still harder, and is an excellent material. That of the San Geronimo is perhaps the most durable, and it is of this that the new postoffice building is constructed, From the Calaveras and Chupaderas creeks, southeast of the city, is taken a very fine quality of flagging stone, which is extensively used here.

The arrival of the railroad also brought a boom in building frame houses with lumber from east Texas and the eastern United States. Local trees were not species that lent themselves to long, straight trunks suitable for lumber. The same City Directory enumerates the trees growing in the vicinity at that time. "The country is well wooded and abounds in pecan, walnut, live oak, black oak, post oak, hackberry and mesquite trees, while in the hills, north of the city, is the natural home of the cedar" (CD 1879:57).

San Antonio builders, most of them of German extraction, were practical and parsimonious in their choice of building materials, using cedar posts wherever possible. Frame houses that became popular in the late 19th century, due to their lighter weight and cohesive construction, were often supported on cedar posts set into the ground, rather than on stone foundations. Thus frame additions such as those later appended to the back of many houses as families grew, and frame rental houses built on the Fischer lot, could be economically supported without the expense of building a masonry foundation. Judging from the cedar posts found in front of the Palm house, this method was also used to support the front porches of the adobe houses. Another type of structure often used during the late nineteenth century for sheds and commercial buildings was the "iron-clad" building. This consisted of a frame of cedar posts sheathed with sheet iron. The Palms had an iron clad building behind their house which apparently was eventually converted into living quarters (Sanborn Insurance Maps 1904, 1912, 1925).

After the Civil War, several attempts were made to open small-scale brick manufacturing plants south of San Antonio, but these did not prove successful. The final blow to local brick-making efforts appears to have been the ability of the railroad to carry large shipments of bricks into town from the east and midwest as well as from the Laredo area. The combination of the availability of comparatively inexpensive brick and a rash of dramatic fires which wiped out downtown districts in a number of Texas cities, gave impetus to a move to build large public buildings, hotels, and rooming houses of solid brick. The availability of this less expensive building material is also reflected in its use in adding the second story to the Tengg house, and in various small additions to other homes in the area. After 1881 when the International-Great Northern Railroad reached Laredo (Tyler 1996:861) inexpensive "mud" brick from Laredo factories was used to line late nineteenth-century privies in the Rivercenter and Alamodome areas, and probably throughout San Antonio. 


\section{Architectural Observations}

In answer to the question of what conditions can be expected to prevail beneath parking lots, we can provide answers based on what was found during this project. Where structures to be removed were adobes, cut stone structures, or brick buildings, apparently all of the building was removed to the top of the foundations and hauled away, rather than being spread out over the lot and compacted there. In other words, there is little or no trace of the building left except for the foundations below grade. In the process, the original occupation surface is nearly always eliminated or badly disarranged. No matter how insecurely mortared, all subsurface foundations were found to be essentially intact. However, we found it was pointless to even try to find original foundations where concrete slabs and grade beams had been removed, particularly in the case of the row of commercial buildings along Commerce Street.

The installation of a parking lot was found to have a beneficial effect, since the seven to 15 inches of compacted gravel beneath the asphalt cushions the weight of the vehicles running over and parking on the sites. The asphalt surface above this permanently seals and protects the entire area.

We can make some general observations from a combination of careful recording of construction of stone houses in the last half of the nineteenth century in San Antonio, both in this project and elsewhere in the city (Table 17-2). Foundations ranging from 18 inches to 24 inches in width were made of cut limestone laid up with sand and lime mortar. Footings were seldom used beneath these foundations. The walls on top of the foundations were generally of caliche block, usually plastered with lime plaster.

Much of the lime used in the plaster and mortar was manufactured in kilns in north Bexar County, where the limestone was immediately available and there was plenty of cedar for firing the kilns. The plaster covered the walls so completely that it was often impossible to tell the material underneath, which led to the use of the term adobes for all such buildings whether or not they were made of adobe.
Some of the more pretentious houses were built with a raised basement, meaning the basement extended half beneath and half above ground level. The Tengg house was an example of this type. However, by far the majority of the houses in San Antonio did not have basements.

The difference in the initial construction of the Degen and Tengg houses demonstrates the practicality of learning to "read" the architectural remains found below the surface. Although the two foundations appear on first examination to be similar, there are subtle differences that reflect the families' financial and social status, even at an early time in their development. The Degen house foundation consisted of a limestone rubble footing upon which was set a shallow, cut limestone foundation supporting caliche block walls. The footing and foundation were mortared with soft sand. The configuration of the foundation is typical of the small adobe houses of lower and middle class San Antonians. The Tengg house foundation consisted of a cut limestone footing and foundation set with sand and lime mortar, which supported the cut limestone first story walls. Beneath the house was a raised basement accessed by an outside stairway, thus saving space within the structure.

Raised basements, cut limestone footings and foundations set in sand and lime mortar, and mortared stone walls were an indication that the owner was willing and, perhaps, able to spend a bit more to have the job done well and to build a more solid, prosperous-appearing home. In the case of the Tenggs, this forethought in building a strong foundation allowed the later addition of a second story. Raised basements and similar foundation construction details were also found at the McDonald house on South Flores Street and the Peter Pauly house in the Alamodome project area. Both owners were educated, upper-class citizens. McDonald was mayor of San Antonio (1851-1852) and alderman (1855). He also owned the first local newspaper (Cox 1991). Pauly was a prominent architect and stone mason (Wright 1997:107).

It is an interesting comment on the times that young Julius Tengg, the son of "an educated man," having what was probably considered a good education for the time and working at the local bookstore, would 
choose to build such a substantial house similar to those of a mayor and an architect. Yet Charles Degen, a brew master whose home was built by a prominent architect and builder, John Kampmann, chose to build an "adobe." These sorts of observations are made possible by the blending of archival, architectural, and archaeological research demonstrated by this project.

Table 17-2. Stone House Construction in San Antonio, 1850-1890

\begin{tabular}{|c|c|c|c|c|c|c|}
\hline Site & $\begin{array}{l}\text { Construction } \\
\text { Approx Date }\end{array}$ & Footing * & Foundation ** & Mortar & House Construction & Reference \\
\hline $\begin{array}{l}\text { Salinas House } \\
\text { Main Plaza }\end{array}$ & 1850 & $\begin{array}{l}\text { irregular stones } \\
24 \text { inches wide }\end{array}$ & $\begin{array}{l}\text { cut limestone } \\
24 \text { inches wide }\end{array}$ & sand and lime & $\begin{array}{l}\text { caliche block } \\
\text { one story }\end{array}$ & $\begin{array}{l}\text { Fox et al. } \\
1989: 42\end{array}$ \\
\hline $\begin{array}{l}\text { Campbell House } \\
223 \text { W. Nueva St. }\end{array}$ & 1855 & none & $\begin{array}{l}\text { cut limestone } \\
24 \text { inches wide }\end{array}$ & sand and lime & $\begin{array}{l}\text { caliche block } \\
\text { one story }\end{array}$ & $\begin{array}{l}\text { Fox et al. } \\
1989: 16\end{array}$ \\
\hline $\begin{array}{l}\text { Anderson House } \\
225 \text { W. Nueva St. }\end{array}$ & 1855 & none & $\begin{array}{l}\text { cut limestone } \\
18 \text { inches wide }\end{array}$ & sand and lime & $\begin{array}{l}\text { caliche block } \\
\text { one story }\end{array}$ & $\begin{array}{l}\text { Fox et al. } \\
1989: 16\end{array}$ \\
\hline $\begin{array}{l}\text { McDonald House } \\
\text { S. Fores St. }\end{array}$ & 1855 & none recorded & $\begin{array}{l}\text { cut limestone } \\
24 \text { inches wide }\end{array}$ & sand and lime & $\begin{array}{l}\text { cut limestone one story } \\
\text { raised basement }\end{array}$ & Cox 1991 \\
\hline $\begin{array}{l}\text { Pauly House } \\
\text { Alamodome }\end{array}$ & 1855 & none recorded & $\begin{array}{l}\text { cut limestone } \\
24 \text { inches wide }\end{array}$ & sand and lime & $\begin{array}{l}\text { cut limestone one story } \\
\text { raised basement }\end{array}$ & $\begin{array}{l}\text { Wrigt } \\
1997: 110-120\end{array}$ \\
\hline $\begin{array}{l}\text { 1st Fischer House } \\
111 \text { Bowie St. }\end{array}$ & 1856 & none recorded & $\begin{array}{l}\text { cut limestone } \\
\text { first house - } 20 \text { inches wide } \\
\text { addition - } 12 \& 14 \text { inches wide }\end{array}$ & mud and lime & $\begin{array}{l}\text { caliche block } \\
\text { one story }\end{array}$ & This report \\
\hline $\begin{array}{l}\text { Caile House } \\
526 \text { E. Nueva St. }\end{array}$ & 1857 & rubble & cut limestone & sand and lime & $\begin{array}{l}\text { caliche block } \\
\text { one story }\end{array}$ & $\begin{array}{l}\text { Fox et al. } \\
\text { 1978:Fig. } 7\end{array}$ \\
\hline $\begin{array}{l}\text { First Mueller House } \\
247 \text { Blum St }\end{array}$ & 1859 & none & $\begin{array}{l}\text { cut limestone } \\
20 \text { inches wide }\end{array}$ & sand and lime & $\begin{array}{l}\text { caliche block } \\
\text { one story }\end{array}$ & This report \\
\hline $\begin{array}{l}\text { Tengg House } \\
326 \text { E. Crockett St. }\end{array}$ & 1867 & $\begin{array}{l}\text { cut limestone } \\
32 \text { inches wide } \\
\text { (main house) }\end{array}$ & $\begin{array}{l}\text { cut limestone } \\
24 \text { inches wide (main house) } \\
18 \text { inches wide (addition) }\end{array}$ & sand and lime & $\begin{array}{l}\text { cut limestone (1st story) } \\
\text { brick (2nd story) raised } \\
\text { basement frame addition }\end{array}$ & This report \\
\hline $\begin{array}{l}\text { Paim House } \\
240 \text { Blum St }\end{array}$ & 1867 & none & $\begin{array}{l}\text { cut limestone } \\
18 \text { inches wide }\end{array}$ & sand & $\begin{array}{l}\text { calich block } \\
\text { one story }\end{array}$ & This report \\
\hline $\begin{array}{l}\text { Smith House } \\
409 \text { N. Flones }\end{array}$ & 1868 & $\begin{array}{l}\text { cut limestone } \\
24 \text { inches wide }\end{array}$ & $\begin{array}{l}\text { cut limestone } \\
18 \text { inches wide }\end{array}$ & sand and lime & $\begin{array}{l}\text { calich block: } \\
\text { one story }\end{array}$ & $\begin{array}{l}\text { Nightengale et al. } \\
\text { 1989:Fig 8a. }\end{array}$ \\
\hline $\begin{array}{l}\text { Degen House } \\
348 \text { E. Crockett St. }\end{array}$ & 1869 & $\begin{array}{l}\text { limestone } \\
\text { rubble } \\
32 \text { inches wide }\end{array}$ & $\begin{array}{l}\text { cut limestone } \\
24 \text { inches wide }\end{array}$ & sand & $\begin{array}{l}\text { caliche block } \\
\text { one story }\end{array}$ & This report \\
\hline Degen Brewery & 1878 & none recorded & cut limestone 18 inches wide & lime and sand & cut limestone one story & This report \\
\hline $\begin{array}{l}2 \text { nd Mueller House } \\
249 \text { Blim St. }\end{array}$ & 1890 & none & $\begin{array}{l}\text { cut limestone and rubble } \\
18 \text { inches wide }\end{array}$ & lime and sand & caliche block & This report \\
\hline
\end{tabular}

* The projecting base of a foundation, intended to spread the weight over a larger area (Baker 1910:355).

** The supporting section of a wall, primarily below ground. 


\section{Part IV: References and Appendixes}

\section{Contents}

References Cited

Appendix A: Faunal Analysis

Appendix B: Local Druggists

Appendix C: An Early Urban Record of Opeas pyrgula

Appendix D: Analysis of Skeletal Remains from the Funeral Pyre Area 


\section{References Cited}

Adams, J. P.

1971 Bottle Collection in America. New Hampshire Publishing, Somersworth, New Hampshire.

Albert, L. S., and K. Kent

1949 The Complete Bottle Book. John Edwards, Stratford, Conn.

Attenbury, P. J.

1979 Europen Pottery and Porcelain. Main Street, Clinton, New Jersey.

Bach, J.

1985 The Main Street Dictionary of Doll Marks. Main Street, Pittstown, New Jersey.

Baker, I. O.

1910 A Treatise on Masonry Construction. John Wiley \& Sons, New York.

Barber, E. A.

1976 The Pottery and Porcelain of the United States and Marks of American Potters. Feingold and Lewis, New York.

Barnes, C. M.

1906 Aged Citizen Describes Alamo Fight and Fire. San Antonio Express, 4 April.

1910 Combats and Conquests of Immortal Heroes Sung in Song and Told in Story. Guessaz and Ferlet, San Antonio.

1911 Builders' Spades Turn Up Soil Baked by Alamo Funeral Pyres. San Antonio Express 26 March.

Bechtol, R.

1984 Heads Up for San Antonio Suds. San Antonio Light. April 4, 1984.

Black, A., and C. Brandimarte

1987 Henderson and Gaines, New Orleans Ceramics Importers. Research Notes, Historic Sites and Materials, Number 2. Texas Parks and Wildlife Department, Austin.

Bollaert, W.

1956 William Bollaert's Texas, edited by Eugene Holland and Ruth Laphan Butler. University of Oklahoma Press, Norman, OK.

Brown, M., and N. De La O

1997 Beneath a Crescent Moon: A Contextual and Architectural Analysis of Privies from the Alamodome Project Area. In Archaeology at the Alamodome: Investigations of a San Antonio Neighborhood in Transition, Vol.II, Artifact and Special Studies, edited by Anne A. Fox, Marcie Renner, and Robert J. Hard. Archaeological Survey Report, No.238, Center for Archaeological Research, The University of Texas at San Antonio, 
Buck, S. M.

1980 Yanaguana's Successors, The Story of the Canary Islander's Immigration into Texas in the Eighteeth Century. Reprinted by Robert Benavides, San Antonio, Texas. Originally published in 1949 by Naylor, San Antonio.

Burkholder, M. V.

1973 The King William Area. The King William Association, San Antonio.

Carskadden, J., and R. Gartley

1990 Chinas: Hand-Painted Marbles of the Late 19th Century. McClain, Parson, West Virginia.

Chabot, F. C.

1937 With the Makers of San Antonio. Privately published, San Antonio.

Corner, W.

1890 San Antonio de Bexar: A Guide and History. Bainbridge and Corner, San Antonio.

Corps of Engineers, United States Army

1972 Flood Plain Information, Olmos Creek, San Antonio, Texas. Prepared with the City of San Antonio and the San Antonio River Authority. Fort Worth, Texas.

Cox, I. W.

1985 10th Street Substation Excavation of the Acequia Madre (41 BX 8), San Antonio, Bexar County, Texas. Archaeological Survey Report No. 153, Center for Archaeological Research, The University of Texas at San Antonio.

1991 Excavations at the McDonald Site, 41BX794, San Antonio, Bexar County, Texas. Archaeological Survey Report No.191, Center for Archaeological Research, The University of Texas at San Antonio.

de la Peña, J. E.

1975 With Santa Anna in Texas: A Personal Narrative of the Revolution. Translated and edited by Carmen Perry, Texas A \& M Press, College Station.

de Zavala, A.

1917 History and Legends of the Alamo and Other Missions in and Around San Antonio. Privately published, San Antonio.

de Espinosa, I.

1709 The Esponosa-Olivares-Aguirre Expidition of 1709. Rev. Gabriel Tous, translator, in Preliminary Studies of the Catholic Historical Society, Volume I, No. 2, 1930, Austin, Texas.

1716 Ramón Expedition: Espinosa's Diary of 1716. Rev. Gabriel Tous, translator, in Preliminary Studies of the Texas Catholic Historical Society, Volume I, No. IV.

Delaney, R. W.

1955 Matamoros, Port for Texas During the Civil War. Southwestern Historical Quarterly, Volume 58:473-487.

Dickens, R. S., Jr., and T. J. Crimmins

1982 Environmental Impact Archaeology in the Urban Setting: A View from Atlanta. In Archaeology of Urban America, The Search for Pattern and Process, edited by R. S. Dickens, Jr. pp.105-116. Academic Press, New York. 
Dolores, M. de los

1762 Documentos para la Historia Eclesiatica y Civil de la Provincia de Texas o Nueva Philipinas, 17201779. Coleccion Chimalistac de Libos y documentos Acerca de la Nueva Espana, Volume 12. Ediciones José Porrua Turanzas, 1961, Marid, Spain.

Everett, D. E.

1975 San Antonio, The Flavor of Its Past, 1845-1898. Trinity University Press, San Antonio, Texas.

Fadala, S.

1979 Black Powder Handbook. Follett, Chicago.

Fehrenbach, T. R.

1968 Lone Star, A History of Texas and the Texans. McMillan, Toronto.

1978 The San Antonio Story. Continental Heritage, Inc., Tulsa, Oklahoma.

Fox, A. A.

1978 Archaeological Investigations of Portions of the San Pedro and Alazan Acequias in San Antonio, Texas. Center for Archaeological Research, the University of Texas at San Antonio, Archaeological Survey Report, No. 49.

1990 Mission Builders: Traces of Texas Archaeology. In The Spanish Mission Heritage of the United States. Selected Papers from the November 1990 Quincentennary Symposium. United States Department of the Interior/National Park Service and Los Compadres de San Antonio Missions National Historical Park, San Antonio, Texas. pp.119-121.

1997 Domestic Architecture in San Antonio. In Archaeology of the Alamodome: Investigations of a San Antonio Neighborhood in Transition, Vol. I, Historical, Architectural, and Oral History Research. edited by Anne A. Fox, Marcie Renner, and Robert J. Hard, pp. 53-65. Archaeological Survey Report, No.236, Center for Archaeological Research, The University of Texas at San Antonio.

Fox, A. A., I. W. Cox, L. Highley, and D. Hafernik

1989 Archaeological and Historical Investigations at the Site of the New Bexar County Justice Center in Downtwon San Antonio, Texas. Archaeological Survey Report, No.184, Center for Archaeological Research, The University of Texas at San Antonio.

Fox, A. A.,D. W. Day, and L. Highley

1990 Archaeological and Historical Investigations at Wallisville Lake, Chambers and Liberty Counties, Texas. Archaeological Survey Report, No.90, Center for Archaeological Research, The University of Texas at San Antonio.

Fox, D. E., F. Valdez, and L. O. Bobbitt

1978 The Dolores Aldrete House Property, San Antonio, Texas. Archaeological Survey Report, No.58, Center for Archaeological Research, The University of Texas at San Antonio.

Frkuska, A. J. Jr.

1981 Archaeological Investigations at the San Pedro Acequia, San Antonio, Texas. Archaeological Survey Report, No. 103. Center for Archaeological Research, The University of Texas at San Antonio.

Gates, W. C. Jr., and D. E. Ormerod

1982 The East Liverpool Pottery District: Identification of Manufacturers and Marks. Historical Archaeology $16(1-2)$. 
Godden, G. A.

1964 Encyclopaedia of British Pottery and Porcelain Marks. Bonanza, New York.

1971 The Illustrated Guide to Mason's Patent Ironstone China and Related Wares. Praeger, New York.

Griffin, T.

1985 Scientists Hail "Treasures" Gleaned in Downtown Dig. San Antonio Express, 2 March.

Greer, G. H.

1981 American Stonewares. Schiffer, Exton, PA.

Greer, G. H., and H. Black

1971 The Meyer Family: Master Potters of Texas. Trinity University Press, San Antonio.

Gross, K. J., and G. Mendez

1997 An Examination of Acequias, Wells, and Cisterns in San Antonio, Texas, ca. 1850-1930. In Archaeology at the Alamodome: Investigations of a San Antonio Neighborhood in Transition. Vol. III, Artifact and Special Studies. Archaeological Survey Report, No.238. Edited by Anne A. Fox, Marcie Renner, and Robert J. Hard. Center for Archaeological Research, The University of Texas at San Antonio.

Habig, M. A.

1968 The Alamo Chain of Missions: A History of San Antonio's Five Old Missions. Franciscan Herald, Chicago.

Hagner, L.M.

1940 Alluring San Antonio Through the Eyes of an Artist. Naylor, San Antonio.

Herff, F. P.

1973 The Doctors Herff: A Three-Generation Memoir. Trinity University Press, San Antonio.

Hindes, K.

1984 A Preliminary Bottle Analysis from a Lateral of the Acequia Madre, Las Tiendas Del Rio Mall Project. Manuscript Series, No. 9. Center for Archaeological Research, The University of Texas at San Antonio.

Israel, F. L.., editor

19681897 Sears Roebuck Catalogue. Reprinted by Chelsea House, New York.

Kendrick, G.

1966 The Antique Bottle Collector. Edwards Brothers, Ann Arbor.

Kerby, R. L.

1972 Kirby Smith's Confederacy: The Trans-Mississippi South, 1863-1865. Columbia University Press, New York, New York.

Kohler, E.

1984 Oral History Interview 11/12/84. On file at CAR. 
Land and Thompson, publishers

1885 Historical and Descriptive Review of the Industries of San Antonio. Reprinted in 1977 by Norman Brock, San Antonio.

Lehner, L.

1988 Lehner's Encyclopedia of U. S. Marks on Pottery, Porcelain and Clay. Schroeder, Paducah, Kentucky.

Leutenegger, Fr. B. and Fr. M. Habig

1977 Journal of a Texas Missionary, 1767-1802, Old Spanish Missions. Historic Research at San José Mission, Documentary Series 3, San Antonio.

Lewis Publishing Company

1907 A Twentieth Century History of Southwest Texas. Volume I. Lewis, Chicago, Ill.

Matloff, M. (editor)

1969 American Military History. Army Historical Service, Office of the Chief of Military History, U.S. Army, Washington, D.C.

Markey, B. J.

1981 Preliminary Cultural Resource Assessment for the Las Tiendas de Rio Shopping Mall Site, San Antonio, Texas. Unpublished manuscript on File, Center for Archaeological Research, The University of Texas at San Antonio.

Mayer, A. J.

1976 San Antonio, Frontier Entrepot. Doctoral dissertation, University of Texas at Austin.

McClintok, W. A.

1930 Journal of a Trip Through Texas and Northern Mexico in 1846-1847. Southwestern Historical Quarterly, Volume 34:141-158.

McCullough, D.

1977 The Path Between the Seas. Simon and Schuster, New York.

McLean, B. J.

1924 The Romance of San Antonio's Water Supply and Water Distribution. San Antonio Printing, San Antonio.

Morgan, B. W.

1961 George W. Brackenridge and his Control of San Antonio's Water Supply, 1869-1905. MA Thesis, Trinity University, San Antonio.

Morrison, A.

1977[1891] San Antonio, Texas. Reprinted by Norman Brock, San Antonio.

Munsey, C.

1970 The Illustrated Guide to Collecting Bottles. Hawthorn, New York. 
Newman, T. S.

1970 The Dating Key for Post-Eighteenth Century Bottles. Historical Archaeology IV:70-75.

Nightengale, B. A., A. A. Fox, and I. W. Cox

1989 Archaeological and Historical Investigations at the Wet End of the Martin and Bowie Streets Connections, San Antonio, Bexar County, Texas. Archaeological Survey Report, No.186, Center for Archaeological Research, The University of Texas at San Antonio.

Nixon, P. I.

1936 A Century of Medicine in San Antonio. Privately published, San Antonio.

Noël Hume, I.

1969 Historical Archaeology. Alfred A. Knopf, New York.

Odom, M. and G. F. Young

1985 The Businesses That Built San Antonio. Living Legacies, San Antonio.

Pool, J. C.

1987 Fanthorp Inn: A Study of Nineteenth and Twentieth Century Buttons. In Archeological Excavations at Fanthorpe Inn State Historic Site (41GM79), Grimes County, Texas, Spring and Fall 1982, pp. 277290. Texas Parks and Wildlife Department, Historic Sites and Restoration Branch, Austin.

Potter, R. M.

1878 The Fall of the Alamo, Magazine of American History, 1860, reprinted January 1878, with additional comments by Union National Bank, Houston, Texas.

Ramsay, J.

1976 American Potters and Pottery. Ars Ceramica, Ann Arbor, Michigan.

Ramsdell, J.

1945 Old Menger Bar Plans Move. San Antonio Light. 11 March 1945.

Richelieu, D. A.

1985a Greatest Move on Wheels. San Antonio Express-News, 10 February.

1985b Fairmount not just any old job for project boss. San Antonio Express-News, 29 March.

1985c 21 March

San Antonio Express-News

1877 The Grand Celebration, 20 February.

1912 [Degan Obituary], 8 February.

1939 J. H. French, One of San Antonio's Best Mayors, 28 February.

1985 Hotel gives competition. 7 April.

Schuetz, M. K.

1966 Historic Background of the Mission San Antonio de Valero. Report No. 1, State Building Commission, Archaeological Program, Austin.

1970 The Cuarteles of San Antonio de Bexar. Manuscript on file. Center for Archaeological Research, The University of Texas at San Antonio. 
Sibley, M. M.

1966 The Burial Place of the Alamo Heros, Southwestern Historical Quarterly, 70(2):272-280.

1973 George Brackenridge, Maverick Philantropist. University of Texas Press, Austin.

Smith, T. T.

1985 Identification of Lead Projectiles from the Mueller Privy. Manuscript on file. Center for Archaeological Research, The University of Texas at San Antonio.

Sutherland, J.

1911 Account of the Fall of the Alamo. Dallas News, 12 February.

Sweet, A., and J. A. Knox

1905 On a Mexican Mustang Through Texas From the Gulf to the Rio Grande. Chatto and Windus, London.

Thorn, C. J.

1947 Handbook of Old Pottery and Porcelain Marks. Tudor, New York.

Toulouse, J. H.

1971 Bottle Makers and Their Marks. Thomas Nelson, New York.

Tyler, R., editor

1996 The New Handbook of Texas. Vol. 3, p 861. Texas State Historical Association, Austin.

Watson, R.

1965 Bitters Bottles. Thomas Nelson and Sons, New York.

Webb, W. P. (editor)

1952 The Handbook of Texas. Two volumes. The Texas State Historical Association, Austin.

Williams, A.

1933 A Critical Study of the Siege of the Alamo and of the Personnel of Its Defenders. Southwestern Historical Quarterly 37:1-184.

Wilson, $\mathrm{R}$.

1981 Bottles on the Western Frontier. The University of Arizona Press, Tucson.

Woolford, S.

1963 San Antonio, a History for Tomorrow. Naylor, San Antonio.

1959 Young Brewmaster Made Menger Beer Popular. San Antonio Light. 15 February.

Woolford, B., and S. Woolford

ca. 1950 The San Antonio Story. Joske's, San Antonio. 
Wright, G. K.

1997 Excavations and Artifact Distribution Analysis. In Archaeology at the Alamodome: Investigations of a San Antonio Neighborhood in Transition, Vol. II, Excavations and Artifact Distribution Analysis. Edited by Anne A. Fox, Marcie Renner, and Robert J. Hard. Archaeological Survey Report, No.237, Center for Archaeolgical Research, The University of Texas at San Antonio.

Yelton, $\mathrm{J}$.

1936 Texas Centennial.

Yeoman, R. S.

1967 A Guide Book of United States Coins. Thomas Nelson, New York. 


\title{
Appendix A: The Vertebrates of Las Tiendas
}

\author{
by William L. McClure
}

This report discusses the vertebrate remains recovered during excavation of parts of the Rivercenter Mall Project on three sites: the Mueller site (41BX637), the Faska site (41BX635), and the Vanderstratton site (41BX634). Bone from units excavated in the yards and a privy in each site is included, as well as the bone from the well on the Vanderstratten property. The count of bones includes both whole bones and fragments. The collection includes 14,656 vertebrate animal remains. Total weight is approximately $50 \mathrm{~kg}$. There are 1591 scales and bones of fishes (10.9 percent), 7 amphibian bones ( $<0.1$ percent), 3519 bird bones (24.0 percent), and 9390 (64.1 percent) mammal bones. No reptiles were identified in the assemblage. One hundred forty-nine bones (1.0 percent) could not be identified to taxonomic class.

The vertebrate remains from Rivercenter were identified by direct comparison with elements in the comparative collections of the Houston Archeological Society and the author. A complete list of the identified taxa and the total count for each is shown in Table A-1. In addition to the faunal remains, a single human tooth was also recovered. There were indications that the tooth had been deliberately extracted.

The excavations yielded nearly 2200 chicken bones and more than 600 others that probably are chicken. A wide variation in lengths of the bones indicates that several varieties of chickens were butchered. By the end of the nineteenth century, the American poultry industry recognized " 87 standard and a large number of promiscuous varieties" of chickens (Howard 1897). It is not to be expected that the varieties could be identified by their bones. However, in order to assist in the analysis, the graph in Figure A-1 was prepared from lengths of bones of chickens of known weight. For this report the estimated weights of chickens represented by the recovered bones are obtained by relating lengths of particular bones to lines on the graph. This is not a valid way to document the actual
Table A-1. Identified Taxa

\begin{tabular}{|c|c|c|}
\hline Taxon & Common Name & Count \\
\hline Osteichthyes & Boncy Fish & \\
\hline Aplodinotus grunniens & Freshwater drum & 17 \\
\hline Archosargus probatocephalus & Sheepshead & 13 \\
\hline Cynoscion nebulosus & Speckled trout & 217 \\
\hline Cyprinus carpio & Carp & 11 \\
\hline Ictalurus cf. melas & Bullhead & 4 \\
\hline Ictalurus punctatus & Channel catfish & 73 \\
\hline Leponis sp. & Sun fish & 4 \\
\hline Micropterus salmoides & Largemouth bass & 42 \\
\hline Pogonias cromis & Black drum & 28 \\
\hline Sciaenops ocellatus & Redfish & 101 \\
\hline Amphibia & Amphians & \\
\hline Bufo sp. & True toads & 1 \\
\hline Rana catesbeiana & Bullfrog & 3 \\
\hline Scaphiopus sp. & Spadefoot toad & 3 \\
\hline Aves & Binds & \\
\hline Anas cf. americana & Duck, possible Wigeon & 8 \\
\hline Anas cf. discors & Duck, possible Teal & 14 \\
\hline Anas cf. platyrhynchos & Duck, possible Mallard & 5 \\
\hline Branta canadensis & Canada goose & 5 \\
\hline Cardinalis cardinalis & Cardinal & 1 \\
\hline Colinus virginianus & Bobwhite & 46 \\
\hline Columba livia & Pigeon & 1311 \\
\hline Gallus domseticus & Chicken & 2194 \\
\hline Icterus cf. galbula & Oriole & 2 \\
\hline Meleagris gallopavo & Turkey & 273 \\
\hline Mimus polyglottos & Mockingbird & 18 \\
\hline Passer domesticus & House sparrow & 1 \\
\hline Zenaida macroura & Mourning dove & 44 \\
\hline Mammalia & Mammals & \\
\hline Bostaurus & Cow & 2472 \\
\hline Canis familiaris & Dog & 94 \\
\hline Capra hircus & Goat & 7 \\
\hline Didelphis virginiana & Opossum & 6 \\
\hline Felis domesticus & House cat & 467 \\
\hline Geomys personatus & Texas pocket gopher & 1 \\
\hline Geomys sp. & Pocket gphers & 6 \\
\hline Lepus califronicus & Blacktail jack rabbit & 62 \\
\hline Mus musculus & House mouse & 7 \\
\hline Neotoma sp. & Woodrat & 8 \\
\hline Odocoileus virginianus & White-tailed deer & 67 \\
\hline Pecaritajacu & Javelina Collared peccary & 5 \\
\hline Rattus norvegicus & Norway rat & 550 \\
\hline Sciurus niger & Eastern fox squirrel & 3 \\
\hline Sus scrofa & Pig & 309 \\
\hline \multirow[t]{2}{*}{ Sylvilagus sp. } & Cottontail rabbit & 160 \\
\hline & Total & 8663 \\
\hline
\end{tabular}


weight of the bird but it gives a fairly reliable estimate. Based on this system, it was determined that the chickens that were butchered varied in weight from 2 to 12 pounds. All of the chickens may have been promiscuous varieties rather than standard breeds. In addition, three hens may have been "fancy" breeds as the lengths of their shanks match four pound birds while the widths are comparable to seven pound birds. As such, they would have been quite heavy for their height.

The degree of ossification of the ends of the bones indicates the relative age of the chicken at the time it was butchered. Some of the chickens were butchered as adults at weights of about 4 pounds while some were still subadults at weights of about 8 pounds.

In an attempt to determine butchering practices, the various bones were grouped according to body parts that reflect major elements after butchering. The bones that would be with the breast are sternum, coracoid and furculum (wish-bone). The leg bones are femur, tibiotarsus, and fibula. The wing bones are humerus, radius and ulna. The back is composed of the fused thoracic vertebrae complex, synsacrum, pelvis complex, ribs, scapula, and pygostyle (tail). The neck bones are all cervical vertebrae and the first thoracic vertebra. The head includes the various bones of the head. The wingtip consists of the carpometacarpus and phalanges of the manus. The shank is the tarsometatarsus. The foot consists of the phalanges of the pes. If all of the bones of the bird are introduced into the dump and are recovered, the neck and feet would be represented by proportionately higher numbers as compared to legs or wings. The same disparity is to be expected for heads, breasts and backs as they often are fragmented when discarded. However, if backs and necks were used for making soup, these bones may have been softened to the extent that they would not be recovered. In addition, some of the foot bones are small enough to pass through the screens. Some bones may have been totally consumed by the pet cats and dogs. Thus, assumptions based on numbers of bones must be relative and rather generalized.

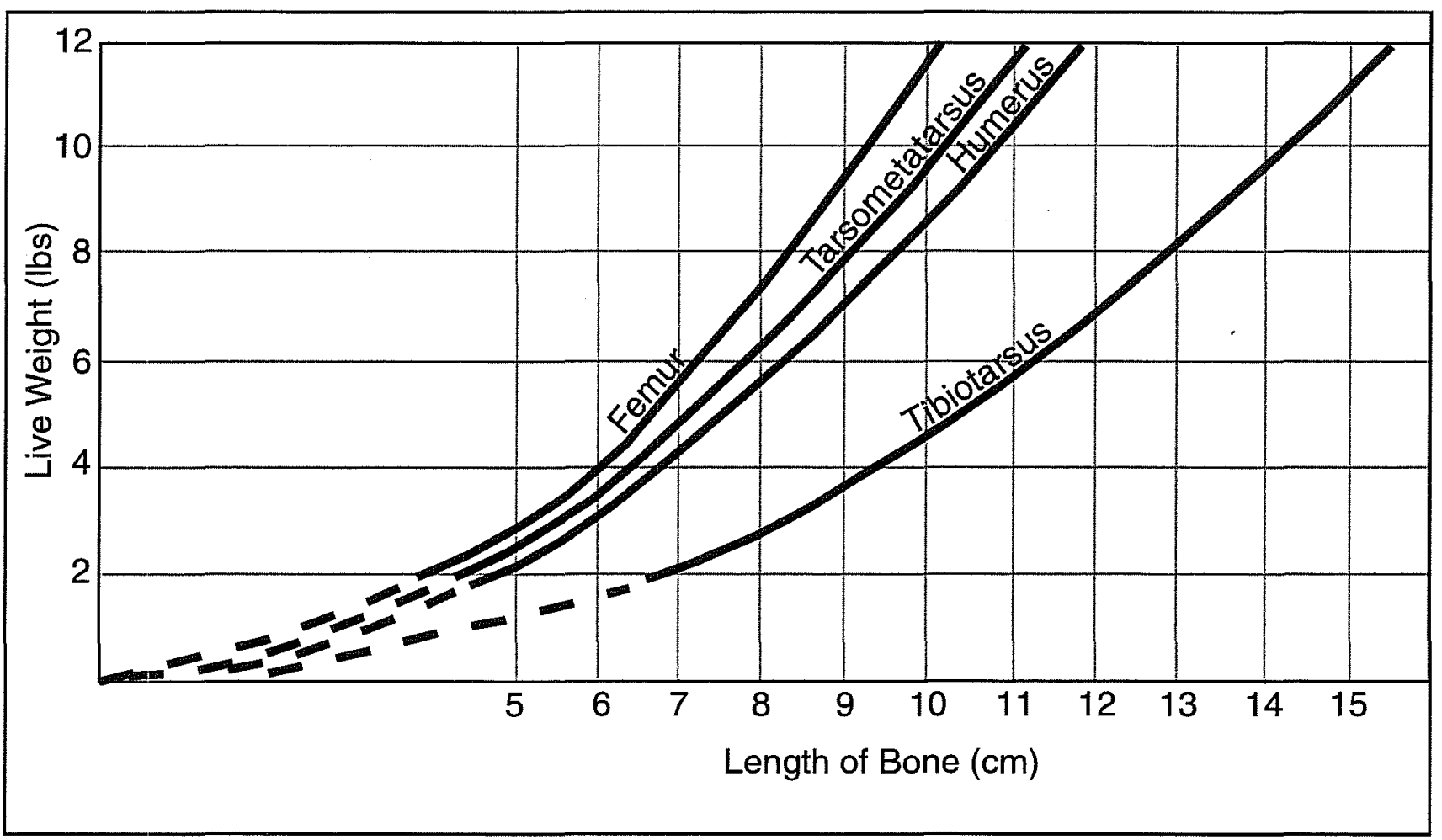

Figure A-1. Chart for estimating live weight of chickens from the length of certain long bones. Based on bone length of chickens of known weight. 
The fragmentary condition of some of the bones and the burned bones suggest that at least some of the refuse may represent secondary deposition. The kitchen trash may have been dumped somewhere, possibly burned, and then periodically gathered up and dumped in the nearest available hole in the ground.

\section{The Mueller Site}

Bone from a privy and several units in the yard are included in this assemblage, with a total of 4915 specimens (Table A-2). Of that number, 13.5 percent were burned. Ninety-nine percent of the burned bones are of pig-sized or larger mammals. Fish comprise 13.6 percent, birds 27.3 percent and mammals 59.1 percent of the numbers of bones. Eleven non-food vertebrates are mockingbird, oriole, cardinal, pocket gopher, Texas pocket gopher, woodrat, Norway rat, house mouse, cat, and dog. Sixteen non-domestic food vertebrates are catfish, bullhead, largemouth bass, redfish, speckled trout, sheepshead, teal, wigeon, mallard, Canada goose, mourning dove, bobwhite, cottontail, jack rabbit, fox squirrel and white-tailed deer. Six domestic vertebrates are pigeon, chicken, turkey, goat, pig and cow. A single human tooth was also recovered in this privy.

The artifact catalogue sheets include items that may be related to the vertebrates. Hunting materials were recovered from the first, second and fourth levels of the privy. Fishing equipment came from the second Level. The upper two levels of the privy appear to form one depositional unit. Although artifacts throughout the privy material indicate it was filled about 1900 , the third and fourth levels have much less bone, almost all of which are from food animals, and may represent a somewhat earlier period of deposition than the first and second levels.

\section{The Mueller Privy}

In Level 1, the remains of at least 16 fish were recovered. Waterfowl are represented by Canada goose, wigeon, and teal. The teal and wigeon bones are from the wing while the goose bones include neck and back as well as wing.
Game birds are represented by 4 doves and 6 bobwhites. The only meat-bearing bone of these 10 birds is from one of the doves. Six cottontail rabbits and two deer were butchered. The heads and feet of the deer were discarded elsewhere. Bones of edible portions of both deer and 3 of the rabbits are in the recovered material. At least 7 pigeons are included in the refuse, of which three are adults and four are young birds. All parts of the body are represented.

Five turkeys were butchered including hens and young toms. All appear to be butcher's refuse, such as feet, heads, and wing tips. At least 79 chickens were butchered including hens and roosters. Edible portions included represent only 7 chickens. Most of the 28 bones of unidentified birds are probably from chickens.

Only seven pig bones were in the refuse. They all could be from one ham cut and include a roast from the upper part and a discarded foot.

A total of 116 beef bones was recovered. Major cuts and the numbers of bones from each are one small end sirloin (6), one hip sirloin (16), one chuck/rib (12), one cross ribs/plate (14), one shoulder clod (4), one brisket (4), one neck (6), two rounds (41) and two shins (7). Miscellaneous bones are 6 fragments of vertebrae. There are $6 \mathrm{~T}$-bone steaks, 10 sirloin steaks, 39 round steaks, 5 chuck steaks and at least 2 roasts.

Unidentified small mammal bones are probably from the cats. Unidentified medium mammal bones are from either the deer or the pig. They include 12 ribs, 7 chops, 2 round steaks and various other fragments. Unidentified cow-size bones are of the beef cuts but are too fragmentary to assign to particular elements.

The deposits of Level 2 included small mammals such as a Texas pocket gopher, four woodrats, one house mouseand at least 5 Norway rats. One mockingbird, one oriole, and one cardinal were thrown into the privy. House cats are represented by 11 babies and 2 kittens in this level.

Bone from at least 9 fish was deposited in Level 2. Waterfowl are represented by a Canada goose and a wigeon. All three bones are from wings. Small game 
Table A-2. Faunal Remains from the Mueller Site

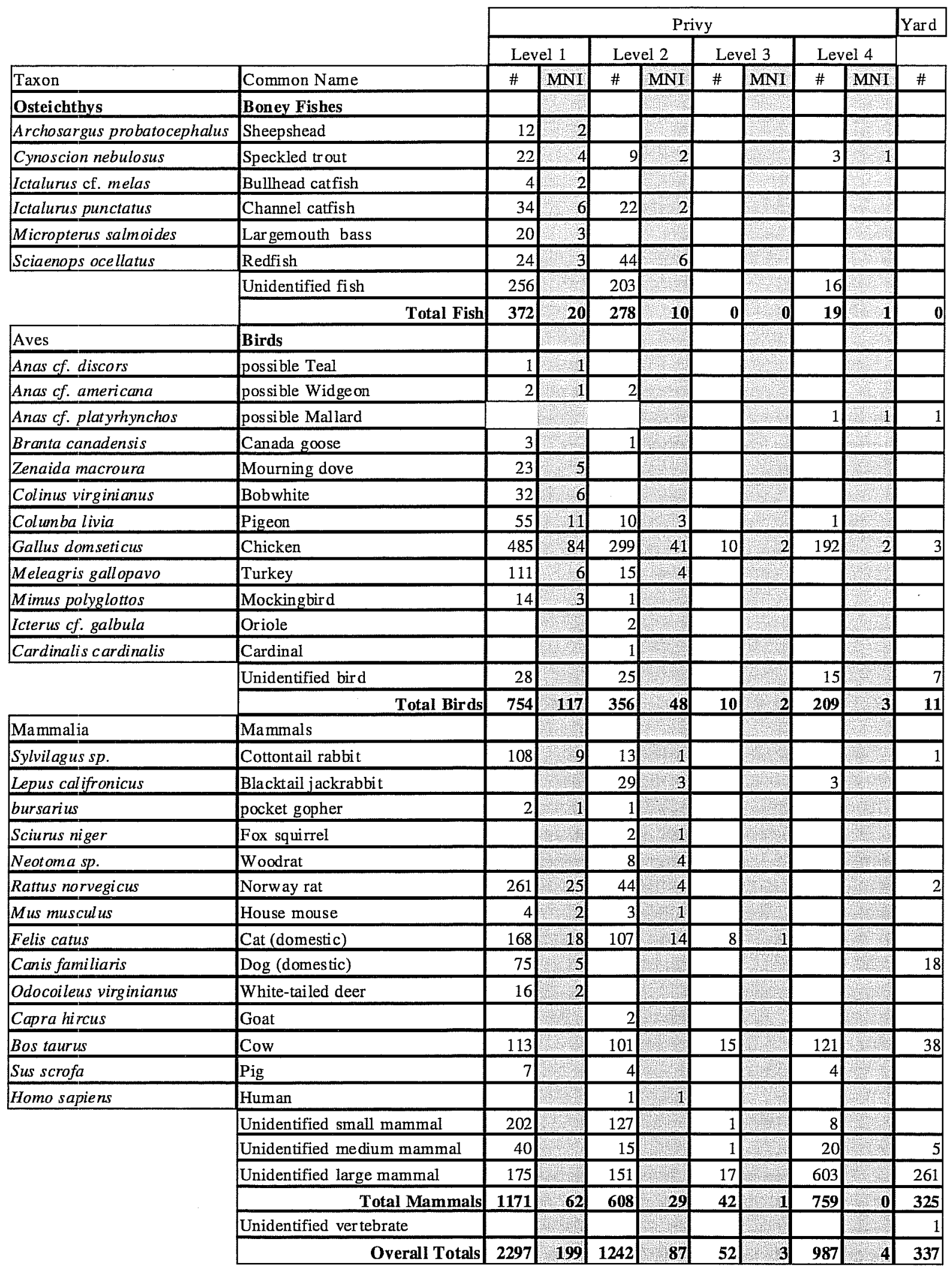


animals are a fox squirrel, one cottontail, and two jack rabbits. Edible parts of only one cottontail are in the refuse.

Two pigeons are included. Both are young birds and edible parts of one are included. Four turkeys were butchered. Apparently they were all young hens. No edible parts are represented by the bones.

At least 38 chickens were butchered including hens and roosters. Edible portions represent only 4 chickens. Most of the 75 bones of unidentified birds are probably from chickens.

Goat bones consist of a calcaneus and an astragalus. Only four pig bones were in the refuse. They represent parts of two ham cuts and a shoulder cut.

A total of 101 beefbones was recovered. Major cuts and the numbers of bones from each are: one small end sirloin (2), one chuck/rib (9), 1 cross ribs/plate (23), one brisket (2), one shin (4), one leg (1), two hip sirloins (25) and two rounds (21). Miscellaneous bones are 14 fragments of vertebrae. There are $2 \mathrm{~T}$-bone steaks, 20 sirloin steaks, 6 chuck steaks, 20 round steaks and at least 2 roasts.

The third level deposits include much less bone material than the first and second. The only non-food items are one rat bone and cat bones. No nondomestic food animals are included. Two chickens were butchered and eaten. The residents processed and ate four different beef cuts which included round steaks, sirloin steaks and a chuck steak.

No non-food animals are represented in the fourth level deposits. The residents were still doing some fishing and hunting as the deposit includes at least one saltwater fish and one jack rabbit. Two chickens were butchered and eaten. One ham cut and eleven major beef cuts are indicated by the refuse. This includes 39 round steaks, 15 sirloin steaks, 6 chuck steaks and 3 T-bone steaks. The diet of the residents remains similar to the earlier intervals. The high percentage of burned material and the low number of non-domestic animals suggests that nearly all of this material reflects secondary deposits.

\section{Yard}

The three excavation units that contain most of the bone material from the yard are probably near the primary disposal location for the kitchen garbage. Area IA-S apparently is the closest as it contains most of the bones. The absence of fish and the paucity of nonfood animal bones and butchering discards of poultry confirm that such materials were seldom discarded at the place of primary disposal of garbage.

\section{Discussion}

Presence of three kinds of native rodents which do not adapt well to urban development indicates that there may have been a sizeable block of vacant land nearby at the time. Unsanitary trash disposal was apparently practiced. This is indicated by at least 27 rats included in the material. At least 30 dead cats (mostly kittens) were thrown into the privy. The residents also kept at least one female dog as indicated by the disposal of a litter of pups. The dogs were of a short-faced breed. The paucity of gnaw marks on bones from either rodents or carnivores indicates that there must have been a fairly stable food source available for these animals.

Apparently an occupant of the residence went hunting and fishing. The artifacts associated with these activities are in the deposits, suggesting that some fish and game were acquired by personal effort rather than from the market. The sea shell is circumstantial evidence that the resident visited the coast where the saltwater fish were caught. Similarly, the presence freshwater mussels support the conclusion that the freshwater fish were caught rather than bought. The waterfowl, upland game birds and mammals and the deer could have been shot either locally or on the trips to the coast. Except for the deer, the majority of the wild fish, birds and mammals appear to have been consumed off the premises. At least 9 pigeons were discarded into the privy. It is possible that they were killed by cats but is probable that they were eaten by the residents. At least 9 turkeys were butchered. Bones from the edible cuts are not included in the refuse. 
At least 117 chickens were butchered. Only 10 percent of the bone are from edible cuts. The artificial eggs indicate that some of the chickens were raised on the premises. Apparently 90 percent of the chickens and all of the turkeys were consumed elsewhere. It is probable that the residents operated a poultry farm and brought the birds to this location for processing. Perhaps they were supplying the local market or a cafe. Egg shells show that they were eating eggs. Estimated live weights of the chickens recovered from this site were made by the procedure described above and counts of the MNI for each weight are shown in Figure A-2.

Apparently a goat was at least partially butchered but there is no indication that it was consumed on premises. Pork bones represent one shoulder cut and three ham cuts. If some of the unidentified material is also pig, as is suspected, the residents consumed a few pork chops and ham steaks as well as roasts. The discarded foot bones indicates that partial butchering was on premises.

Beef bones are the major element in the bone refuse. The residents apparently processed and ate the following cuts: 2 small end sirloins, 3 hip sirloins, 2 chuck/rib, 2 cross ribs/plate, 1 shoulder clod, 2 briskets, 1 neck, 4 rounds, 3 shins and 1 leg. This includes 59 round steaks, 30 sirloin steaks, 11 chuck steaks, 8 T-bone steaks and several roasts.
About 8 percent of the bones from the first two levels were burned. However, this is 38.5 percent of the bones from pig-size and larger animals. This indicates that the burning occurred outside the privy and was concentrated on the pork and beef bones. Only 5 bones of smaller animals were burned. This disparity indicates that two different disposal methods were practiced. The non-food animals were dumped directly into the privy. Also, the discard parts of the fish, waterfowl, small game and poultry were dumped directly into the privy. The pork and beef bones were placed somewhere else and subjected to partial burning before being dumped into the privy. The residents apparently had a container or place in the yard where the kitchen garbage was placed and burned. Later, they would gather the unburned debris and dump it into the privy.

\section{Conclusions:The Mueller Site}

Based on analysis of bones in the Mueller yard and privy, the following conclusions appear to be tenable:

At the time that the privy was converted from its intended function into a trash pit, there was some undeveloped acreage nearby. Trash disposal in the neighborhood was unsanitary. These conditions encouraged proliferation of commensal rodents.

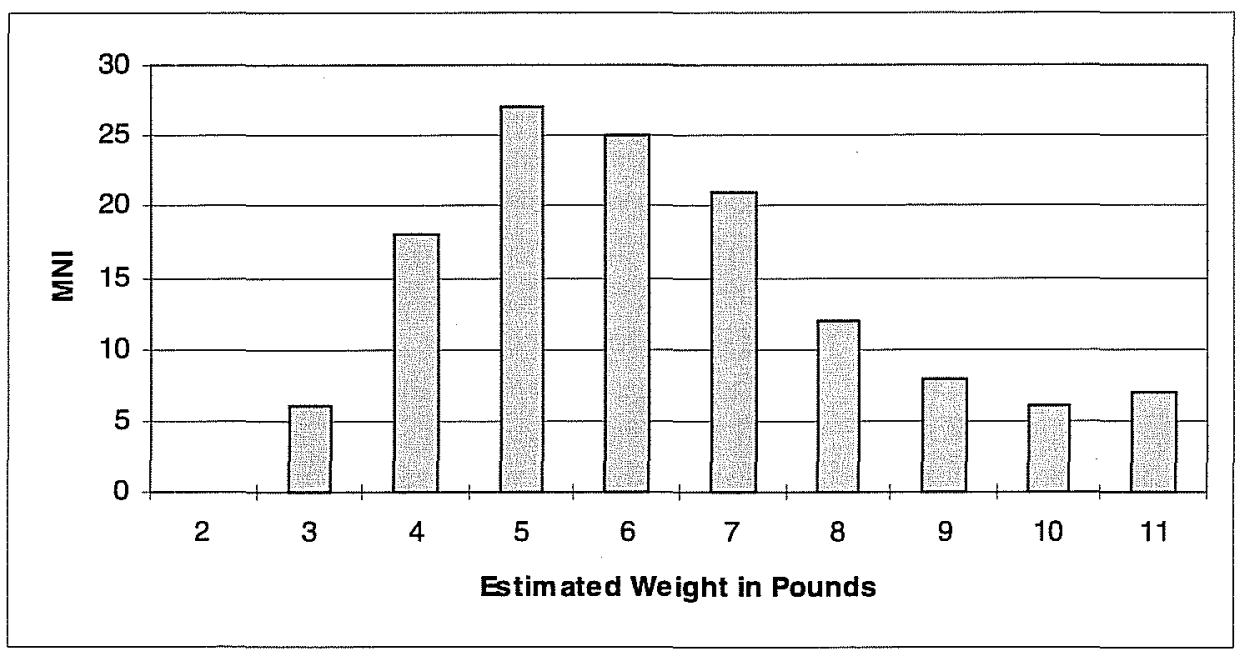

Figure A-2. Estimated live weights of chickens from the Mueller Site. Note the total MNI for chickens from this site was 130 .
The residents kept cats and dogs. The cat and dog populations were controlled by killing some of the kittens and puppies and their bodies were thrown into the privy.

One or more of the residents went hunting and fishing, both locally and at the coast. The fish, water-fowl, game birds and small game mammals were butchered and the discard parts were thrown into the privy. The edible parts were seldom eaten by the residents and 
may have been supplied to the local market or a cafe.

The residents butchered chickens and turkeys, most of which were probably raised at another location. Most of the poultry was not consumed by the residents but may have been supplied to the local market or a cafe.

Pigeons, deer, pork and beef were consumed by the residents with beef being the dominant item. Major cuts of all parts of the beeves were acquired with roasts and steaks being cut by the cook.

Garbage from the kitchen was placed somewhere in the yard near unit IA-S, where it was burned. The unburned residue was occasionally gathered and dumped into the privy.

The residents of the property may have operated a poultry farm, a market or a cafe.

\section{The Faska Site}

A total of 1719 vertebrate remains were recovered from a privy and 2 units in the yard at the Faska Site (Table A-3), of which12.5 percent were burned. Fish bone were only 1.3 percent of the total while 5.6 percent were birds, and 91.9 percent were mammals. All except one of the burned bones are of pig-sized or larger mammals. Four non-food vertebrates are house sparrow, pocket gopher, Norway rat and cat. Six nondomestic food vertebrates are redfish, largemouth bass, mourning dove, cottontail, jack rabbit and deer. Five domestic vertebrates are pigeon, turkey, chicken, pig and cow.

\section{Faska Privy}

Artifacts from the Faska privy indicate that it was filled slowing between about 1900 and 1910. A total of 1699 bone were recovered, of which 1.2 percent are from fish, 5.2 percent are frombirds, and 89.8 percent are from mammals. The artifact catalog sheets show hunting materials were recovered from the second and third levels and freshwater mussel shell came from the third level.
Rodents in the first level are represented by one gopher and three Norway rats. House cats are represented by 3 kittens of three different ages. The remains of 2butchered fish are present.

Game birds and mammals are represented by 3 mourning doves, one jack rabbit, and a deer. These include edible portions of the doves and rabbit but not the deer.

Only one pigeon is included in the deposit. An edible portion is present. One turkey is represented by bones of the wingtip and the foot. At least 3 hen chickens were processed and eaten. Major cuts and the numbers of bones of each are one breast (1), one leg (1), two backs (8), one neck (4), three wings (3), one head (4), two shanks (2) and one foot (4). Most of the bones of unidentified birds are probably from the chickens.

Only 7 pig bones were in the refuse. They are from one ham cut, one shoulder cut and discard parts of head and foot. A total of 285 beef bones was recovered. The numbers of bones of major cuts are small end sirloin (19), hip sirloin (136), chuck/rib (4), cross ribs/ plate (60), shoulder clod (1), round (7), socket/rump (2), shin (1) and leg (1). There are 17 T-bone steaks, 40 sirloin steaks, 7 round steaks and at least one roast. The T-bones were cut uniformly and the other steaks irregularly.

Only three pig bones are included in Level2. These are discarded foot bones and a round steak cut from a tibia.

A total of 78 beef bones was recovered. The numbers of bones from major cuts are hip sirloin (38), chuck/ rib (6), cross ribs/plate (23), round (1), leg (2).

Level 3 deposits include 1 wing bone of a house sparrow. Rodents are represented by two Norway rats. House cats are represented by two kittens. Unidentified fish are two fish steaks cut across the vertebrae of a large fish and 6 other bones.

Edible portions of one cottontail and one deer are present. Four bones of a turkey are from the inedible part of the foot and shank. At least 5 chicken were processed and eaten. Major cuts and the numbers of 
Table A-3. Faunal Remains from the Faska Site.

\begin{tabular}{|c|c|c|c|c|c|c|c|c|c|c|c|}
\hline \multirow[b]{3}{*}{ Taxon } & \multirow[b]{3}{*}{ Common Name } & \multicolumn{8}{|c|}{ Privy } & \multicolumn{2}{|c|}{ Yard } \\
\hline & & \multicolumn{2}{|c|}{ Layer 1} & \multicolumn{2}{|c|}{ Layer 2} & \multicolumn{2}{|c|}{ Layer 3} & \multicolumn{2}{|c|}{ Layer 4} & \multirow[b]{2}{*}{ Count } & \multirow[b]{2}{*}{ MNI } \\
\hline & & Count & MNI & Count & MNI & Count & MNI & Count & MNI & & \\
\hline Osteichthys & Boney Fish & & & & . & & & & 10 & & \\
\hline Micropterus salmoides & Largemouth bass & & 1 & & 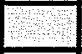 & & & & 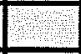 & 1 & 1 \\
\hline \multirow[t]{3}{*}{ Sciaenops ocellatus } & Redfish & 5 & 1 & & & & & & 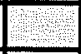 & & $=$ \\
\hline & Unidentified fish & 9 & - & & & 6 & & & 4 & 1 & 5 \\
\hline & Total Fish & 15 & 2 & 0 & 0 & 6 & 0 & & 0 & 2 & 1 \\
\hline Aves & Birds & & & & & & & & $\square$ & & \\
\hline Zenaida macroura & Mourning dove & 8 & 3 & & & & & & $\square$ & & \\
\hline Columba livia & Pigeon & 2 & 1 & & & & & & & & \\
\hline Gallus domseticus & Chicken & 26 & 3 & 1 & & 17 & 5 & & & 7 & \\
\hline Meleagris gallopavo & Turkey & 3 & 1 & & & 4 & 1 & & & & D. \\
\hline \multirow[t]{3}{*}{ Passer domesticus } & House sparrow & & & & & 1 & 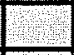 & & 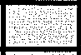 & & 1 \\
\hline & Unidentified bird & 16 & & & & 10 & & & 5? & & $\square$ \\
\hline & Total Birds & 55 & 8 & 1 & 0 & 32 & 6 & 1 & 0 & 8 & 5 \\
\hline Mammalia & Mammals & & 7 & & & & + & & Pra & & \\
\hline Sylvilagus sp. & Cottontail rabbit & & & & & 5 & 1 & & & & 1 \\
\hline Lepus califronicus & Blacktail jackrabbit & 3 & 1 & & & & & & 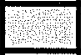 & & \\
\hline Geomys bursarius & Plains pocket gopher & 3 & 1 & & & & & & & & \\
\hline Rattus norvegicus & Norway rat & 24 & 3 & & & 21 & 2 & & 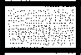 & 1 & \\
\hline Felis catus & Cat (domestic) & 24 & 3 & & & 7 & 2 & & 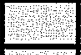 & & \\
\hline Odocoileus virginianus & White-tailed deer & 1 & & & 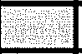 & 2 & & & 3 & & \\
\hline Bostaurus & Cow & 285 & 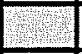 & 77 & & 110 & 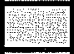 & 2 & Pris & 34 & \\
\hline \multirow[t]{6}{*}{ Sus scrofa } & Pig & 7 & & 3 & 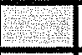 & 4 & rar & & P. & 2 & \\
\hline & Unidentified medium mammal & 60 & & 10 & 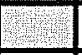 & 35 & & & 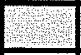 & & \\
\hline & Unidentified large mammal & 377 & 3 & 86 & 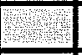 & 380 & & & 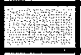 & 16 & W \\
\hline & \begin{tabular}{r|} 
Total Mammals \\
\end{tabular} & 784 & 8 & 176 & 0 & 564 & 5 & 2 & $=0$ & 53 & 1 \\
\hline & Unidentified Vertebrate & 20 & in & & 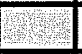 & 43 & 1. & & manting & & 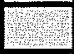 \\
\hline & \begin{tabular}{|c|} 
Overall total \\
\end{tabular} & 874 & 18 & 177 & 0 & 645 & 11 & 3 & 0 & 63 & \\
\hline
\end{tabular}

bones of each are two breasts (3), three legs (6), two wings (4), neck (1), head (1), wingtip (1) and two shanks (2). Most of the bones of unidentified birds are probably from the chickens.

Only 4 bones definately identified as pig are included, and they are from the foot. However, the unidentified medium mammals ( 35 bones) are probably also pig and include 3 round steaks and other fragments.

A total of 114 beef bones was recovered. The numbers of bones of major cuts are hip sirloin (28), chuck/rib (2), socket/rump (1), cross ribs/plate (34), shoulder clod
(3), brisket (4), shin (2), leg (4) and round (10). There are 26 sirloin steaks and 10 round steaks.

Level 4 contained only three bones, including a chicken, represented by one leg bone, and 2 beef roast bones.

\section{Faska Yard}

Bones were recovered from two units that were excavated in the Faska yard other than within the privy. No indications of burning were noted. 
All of the 27 bones from Unit 1 are cow or probable cow. The lower level includes bones from the beef cuts chuck/rib (10), socket/rump (5), shoulder clod (3), neck (1), round (1) and shin (2). There are 2 rump steaks and at least 1 roast. The upper level of Unit 1 yielded only 3 fragments.

In the lower level of Unit 2 there were 21 bones. Bones of three chickens are included. Only one is represented by edible parts. A pig is represented by a foot bone and a thin ham steak. Beef bones consist of a carpal and 12 fragments.

In the upper level of Unit 2 there were 18 bones. One bone of a Norway rat was recovered. One bone each of a largemouth bass and an unidentified fish are included. The lower end of a turkey drumstick and a leg bone and a shank of a chicken hen were recovered. Twelve cow bones are of the beef cuts small end sirloin (2), hip sirloin (6), chuck/rib (1) and shin (3). Three sirloin steaks were eaten.

\section{Discussion}

Three rats and three kittens reveal that the residents probably kept cats to control the rats. The sawed vertebrae of a large fish indicates that the residents ate fish and probably bought fish steaks at the market. The smaller fish bones and the freshwater mussel shell may be circumstantial evidence of fishing effort. The people did a little hunting because cartridge cases and bones of rabbit and deer are included. However, these wild foods were only a minor part of the diet. Chickens and turkeys were butchered and the bones suggest that the chickens that were butchered were eaten while the turkey may have been consumed elsewhere. Estimated live weights of the chickens recovered from this site were made by the procedure described above and counts of the MNI for each weight are shown in Figure A-3.

Pigs were butchered and at least partially eaten at the site. Beef bones are the dominant element of the refuse. Seven different major cuts were acquired and $\mathrm{T}$-bone steaks, sirloin steaks, round steaks, and a few roasts were consumed. The T-bone steaks may have been bought at the market but the others were probably cut by the cook.

The high number of bone fragments with very few being burned indicates the probability that the material represents a secondary deposit.

Excavations of two units in the yard yielded an array of bones that is similar to those recovered in the privy. Beef is the dominant element with chicken and pork in lesser numbers. Apparently no burning was conducted in these units.

\section{Conclusions: The Faska site}

Based on analysis of bones in the Faska privy and yard, the following conclusions appear to be tenable:

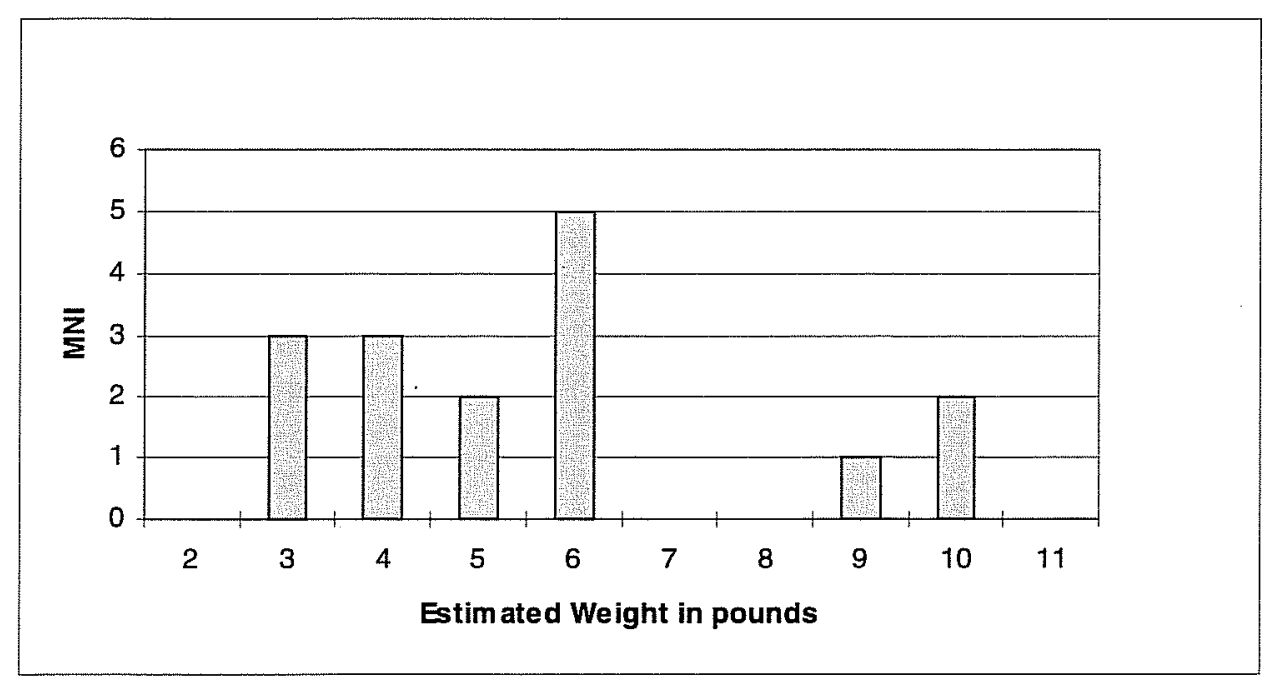

Figure A-3. Estimated live weights of chickens from the Faska Site.Note the total MNI for chickens from this site was 16. 
Sometime after the privy was constructed there was undeveloped land nearby. Trash disposal in the neighborhood was unsanitary. These conditions encouraged proliferation of commensal rodents.

The residents kept a few cats. The cats may have killed some of therats and birds which were thrown into the privy. The cat population was controlled by killing some of the kittens and their bodies were thrown into the privy.

One or more of the residents did a little hunting and fishing. The fish, game birds and small game mammals were butchered and the discard parts were thrown into the privy. Some fish were purchased at the market and this may include the only saltwater fish that was recovered. The residents butchered a deer, a pig, chickens and a few turkeys. The turkeys and some of the pork and venison may not have been consumed by the residents.

Fish, pigeons, chickens, deer, pork and beef were consumed by the residents with beef being the dominant item. T-bone steaks and major beef cuts were acquired at the market with roasts and other steaks being cut by the cook. Garbage from the kitchen was placed somewhere in the yard where it was burned. The burning was not located at the two units that were excavated in the yard. Unburned residue was occasionally gathered and dumped into the privy.

\section{The Vanderstratten Site}

A total of 7979 bones were recovered from the Vanderstratten site. This includes 2789 from the privy, 5065 from the well, and 125 from 18 excavation units in the yard. Of this 0.1 percent are amphibians, 11.3 percent are fish, 26.1 percent are birds, and 61.5 percent are mammals.

\section{Vanderstratten Privy}

Only 13 bones( 0.5 percent) of the 2789 that were recovered from the privy had been burned (Table A-4). Fish comprise 1.7 percent, birds 49.8 percent, and mammals 48.4 percent of the total. Less than 0.1 percent of the bones are of amphibians. Four non-food vertebrates are spadefoot toad, pocket gopher, Norway rat and house cat. Thirteen non-domestic food vertebrates are catfish, largemouth bass, sunfish, carp, bobwhite, teal, wigeon, mallard, mourning dove, jack rabbit, fox squirrel, javelina and white-tailed deer. Six domestic food vertebrates are pigeon, turkey, chicken, goat, pig and cow.

Artifacts indicate that the first 6 levels are from about the same time period: roughly $1890-1910$. The lowest level appears to be a somewhat earlier deposit. The artifact catalogue sheets include hunting materials in the third and sixth levels. Fishing effort may be indicated by mussel shell in the third level and trips to the coast by a sea urchin in the third level. Home butchering may be supported by equipment reported in the second level.

Bones of house cats were recovered from the first 3 levels and bones of rats were recovered from the first 6 levels. Thus, during the time that the privy was used for disposal of rubbish, the residents kept cats and the cats probably caught some of the rats.

The deposits in Level 1 include 1 Norway ratand 1 adult house cat. A pigeon and a turkey are represented by bones of the wings. At least 5 chickens were butchered. The major cuts and the numbers of bones of each are wing (6); wingtip (1); head (4) and shank (7). The edible parts may have been discarded elsewhere.

The seven pig bones would have been from three separate ham cuts. At least 2 of the hams were cured with the meat sliced from the bone.

A total of 22 beef bones are included. Major cuts and the numbers of bones from each are chuck/rib (4); socket/rump (1); cross ribs/plate (12); brisket/ navel (1); femur (1) and miscellaneous vertebrae fragments (3). No steaks are included.

Deposits in Level 2 include a spadefoot toad, 5 Norway rats, a pocket gopher, and 3 house cats. Two fish were identified. Other non-domestic food animals in the 
Table A-4. Faunal Remains from the Vanderstratten Privy

\begin{tabular}{|c|c|c|c|c|c|c|c|c|c|c|c|c|c|c|c|c|c|}
\hline \multirow[b]{3}{*}{ Osteichthys } & \multirow[b]{3}{*}{ Boney Fish } & \multicolumn{2}{|c|}{ Layer 1} & \multicolumn{2}{|c|}{ Layer 2} & \multicolumn{2}{|c|}{ Layer 3} & \multicolumn{2}{|c|}{ Layer 4} & \multicolumn{2}{|c|}{ Layer 5} & \multicolumn{2}{|c|}{ Layer 6} & \multicolumn{2}{|c|}{ Layer 7} & \multicolumn{2}{|c|}{ Mixed } \\
\hline & & Cnt & MNI & Cnt & MNI & Cnt & MNI & Cnt & MNI & Cnt & MNI & Cnt & MNI & Cnt & MNI & Cnt & MNI \\
\hline & & & & & & & $=$ & & & & & & 5 & & & & \\
\hline Lepomis sp. & Sunfish & & & & & 8 & 2 & 6 & 1 & & & & & & & & \\
\hline Aplodinotus grunniens & Freshwaterdrum & & & 4 & & & धः & & & & & & & & & & \\
\hline Cyprinus carpio & Carp & & & & & 9 & 1 & & & & & & & & & & \\
\hline \multirow[t]{3}{*}{ Sciaenops ocellatus } & Redfish & & & 2 & & & & & & & & & & & & & \\
\hline & Unidentified fish & & & 12 & & 5 & & & $\sqrt{4}$ & & & 1 & & & & & \\
\hline & Total Fish & $\mathbf{0}$ & $\mathbf{0}$ & 18 & $\mathbf{0}$ & 22 & 3 & 6 & 1 & $\mathbf{0}$ & 0 & 1 & 0 & $\mathbf{0}$ & 0 & $\mathbf{0}$ & 0 \\
\hline Amphibia & Amphibians & & & & & & & & & & & & & & $\longdiv { 1 0 }$ & & \\
\hline \multirow[t]{2}{*}{ Scaphiopus sp. } & Spadefoot toads & & & 2 & & & 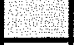 & & (1) & & & & & & 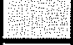 & & \\
\hline & $\begin{array}{l}\text { Total } \\
\text { Amphibians }\end{array}$ & $\mathbf{0}$ & 0 & 2 & 0 & $\mathbf{0}$ & 0 & $\mathbf{0}$ & 0 & $\mathbf{0}$ & 0 & $\mathbf{0}$ & 0 & $\mathbf{0}$ & 0 & 0 & 0 \\
\hline Aves & Birds & & & & & & & & (1) & & $\sqrt{2}$ & & 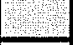 & & & & \\
\hline Anas cf. americana & poss. Wigeon & & & & & 9 & 1 & & & & & & ?בו & & & & \\
\hline Anas cf.platyrhynchos & poss. Mallard & & & 2 & & & & & & & 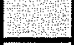 & & & & & & \\
\hline Zenaida macroura & Mourning dove & & 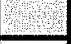 & & 4 & & 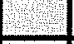 & 1 & & 5 & 1 & 2 & 1 & & 3 & & 1 \\
\hline Colinus virginianus & Bobwhite & & & 6 & & 1 & 1 & & & 1 & & & & & & & $y$ \\
\hline Columba livia & Pigeon & 5 & 1 & 9 & 3 & & W & & I & & 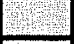 & & 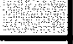 & & be & & ב \\
\hline Gallus domseticus & Chicken & 18 & 5 & 496 & 40 & 279 & 45 & 62 & 14 & 34 & 7 & 24. & 8 & 1 & & 4 & 2 \\
\hline \multirow[t]{3}{*}{ Meleagris gallopavo } & Turkey & 7 & 1 & 60 & 10 & 52 & 5 & 6 & 2 & 6 & 1 & 1 & 1 & & 5 & & 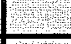 \\
\hline & Unid. bird & & & 224 & (4) & 53 & 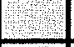 & 7 & 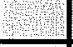 & 11 & 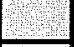 & 3 & & & m & & \\
\hline & Total Birds & 30 & 7 & 797 & 53 & 394 & 52 & 76 & 16 & 57 & 9 & 30 & 10 & 1 & 0 & 4 & 2 \\
\hline Mammalia & Mammals & & 12 & & 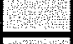 & & 14 & & & & 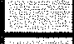 & & m & & & & 位 \\
\hline Lepus califronicus & $\begin{array}{l}\text { Blacktail } \\
\text { jackrab bit }\end{array}$ & & & 5 & 1 & 4 & 2 & & & & & 1 & 1 & & & & \\
\hline Geomys sp. & Pocket gophers & & & 1 & & & $=$ & & & & 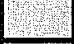 & & & & & & \\
\hline Sc iruis niger & $\begin{array}{l}\text { Eastern fox } \\
\text { squirrel }\end{array}$ & & & $\mathbf{I}$ & 1 & & & & & & & & & & & & \\
\hline Rattus norvegicus & Norway rat & 2 & 1 & 31 & 5 & 31 & 4 & 15 & 2 & 22 & 4 & 3 & 1 & & Y. & & \\
\hline Felis domesticus & House cat & 38 & 1 & 38 & 3 & 31 & 1 & & 列 & & 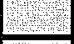 & & 3 & & rten & & 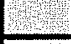 \\
\hline \begin{tabular}{|llllllllll}
$O$ & $d$ & $o$ & $c$ & $o$ & $i$ & $l$ & $e$ & $u$ & $s$ \\
virginianus
\end{tabular} & $\begin{array}{l}\text { White-tailed } \\
\text { deer }\end{array}$ & & & 2 & & 8 & 1 & 3 & 1 & & & & & & & & \\
\hline Capra hircus & Goat & & & 1 & & 2 & & & & 2 & & & & & & & \\
\hline Bos taurus & Cow & 22 & & 142 & & 234 & & 33 & & 55 & & 35 & & 38 & & 7 & \\
\hline Sus scrofa & Pig & 7 & & 8 & & 7 & 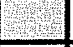 & 5 & & 1 & & 2 & & & ?. & & \\
\hline \multirow[t]{6}{*}{ Pecari tajacu } & \multicolumn{2}{|l|}{$\begin{array}{l}\text { Javelina, } \\
\text { Collared Peccary }\end{array}$} & & & & & & & & 5 & 1 & & & & & & \\
\hline & \multicolumn{2}{|c|}{ Unid small mammal } & & 12 & & 28 & 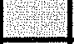 & & & 8 & & & & 3 & & & \\
\hline & $\begin{array}{l}\text { Unid medium } \\
\text { mammal }\end{array}$ & 3 & & 23 & & 32 & & 4. & & 15 & & 12 & & 6 & & 4 & \\
\hline & $\begin{array}{l}\text { Unid large } \\
\text { mammal }\end{array}$ & 10 & & 15 & & 113 & & 39 & & 61 & & 50 & & 31 & & 40 & \\
\hline & $\begin{array}{r}\text { Total } \\
\text { Mammals } \\
\end{array}$ & 82 & 2 & 279 & 10 & 490 & 8 & 99 & 3 & 169 & 5 & 103 & 2 & 78 & 0 & 51 & 0 \\
\hline & Overall Total & 112 & 9 & 1096 & 63 & 906 & 63 & 181 & 20 & 226 & 14 & 134 & 12 & 79 & $\mathbf{0}$ & 55 & 2 \\
\hline
\end{tabular}


deposit are 2 bobwhites, 1 mallard, 1 jack rabbit, 1 fox squirrel, and a deer.

Three pigeons are represented. At least 10 turkeys were butchered with most of the bones of edible parts being discarded elsewhere. At least 40 chickens were butchered with most of them being eaten on the premises. The major cuts and the numbers of bones of each are breast (54), leg (78), back (81), neck (21), wing (75), wingtip (19), head (95), shank (38) and foot (26). Unidentified birds (224 bones) are probably all from the chickens. A goat is represented by one bone. Two pigs may have been butchered as the deposit includes bones from the head, feet and ham cuts).

The deposit includes 147 beef bones. Major cuts and the number of bones of each are small end sirloin (5), hip sirloin (54), chuck/rib (13), socket/ rump (7), cross ribs/plate (12), shoulder clod (6), brisket/navel (4), neck (1), shin (17), leg (2), round (12), vertebrae fragments (11), 2 patellas and one malleolus. This includes 35 sirloin steaks, 16 sacrum steaks, 2 chuck steaks and 8 round steaks.

Non-food animals in Level 3 include 4 Norway rats and a young adult house cat ( 31 bones). Fish included in the interval are 1 channel catfish, 1 largemouth bass and unidentified fish. Other non-domestic animals in the deposit are bobwhite, a teal, 1 jack rabbit, and a deer

Five turkeys were butchered and edible parts of some of them are in the refuse. About 45 chickens were butchered with most of them being consumed on the premises. Major cuts and the number of bones of each are breast (22), leg (40), back (34), neck (12), wing (29), wingtip (7), head (105), shank (21) and foot (9). Most of the unidentified bird bones (53) are from the chickens.

A goat ( 2 bones) is represented by foot bones. At least 2 pigs are represented by ham cuts. At least 1 of these hams was cured with the meat being sliced from the bone.

A total of 232 beef bones are included. Major cuts and the number of bones from each are small end sirloin (33), hip sirloin (73), chuck/rib (5), cross ribs/ plate (16), shoulder clod (2), brisket/navel (11), neck (11), shin (30), leg (12), round (17), vertebrae fragments (21) and one patella. This includes $27 \mathrm{~T}$ bone steaks, 73 sirloin steaks and 13 round steaks.

The only non-food animals in Level 4 were 2 Norway rats. Non-domestic animals include a channel catfish, a dove, and a deer.

Two turkeys are represented by bones of the heads and one thigh. At least 14 chickens were butchered and about half are represented by bones of the edible parts. The major cuts and the numbers of bones of each are breast (5), leg (8), neck (5), wing (5), head (32), shank (4) and foot (3). The 7 bones of unidentified birds are probably from the chickens.

A pig is represented by bones of the shoulder cut and a ham cut including foot bones. There are 33 beef bones included. Major cuts and the number of bones of each are small end sirloin (6), hip sirloin (16), cross ribs/plate (4), shin (4), leg (1) and round (2). This includes $4 \mathrm{~T}$-bone steaks, 6 sirloin steaks and 2 round steaks.

Four Norway rats are recovered from Level 5. Nondomestic animals are 1 bobwhite, 1 dove and 1 javelina

A turkey and 7 chickens were identified. Very few edible parts are included. For the chickens the major cuts and the number of bones of each are breast (3), leg (2), back (4), neck (3), head (19) and shank (3). The eleven bones of unidentified birds are probably from the chickens.

A goat is represented by edible parts. A pig is represented by one bone from the shoulder cut. There are 55 beef bones. Major cuts and the number of bones of each are small end sirloin (22), hip sirloin (8), chuck/ rib (6), cross ribs/plate (9), shoulder clod (1), brisket/ navel (1), leg (2), round (3) and miscellaneous vertebrae fragments (3). This includes $17 \mathrm{~T}$-bone steaks, 6 sirloin steaks, 3 chuck steaks and 3 round steaks. 
A single Norway rat is represented in Level 6. One bone of an unidentified fish was recovered. Other nondomestic animals are a dove and a jack rabbit

A turkey is represented by only one bone. Eight chickens were butchered and several of them were consumed on the premises. The major cuts and the number of bones of each are breast (1), back (3), neck (4), wing (3), wingtip (1), head (11) and shank (1). The 3 bones of unidentified birds are probably from the chickens.

Two pig bones are of the foot. There are 35 beef bones included. Major cuts and the number of bones of each are small end sirloin (1), hip sirloin (5), chuck/rib (2), cross ribs/plate (12), shin (1), leg (3), round (3) and 8 vertebrae fragments. This includes 5 sirloin steaks and 2 round steaks.

Non-domestic animals from Level 7 include a wigeon and a deer. A chicken is represented by a neck bone. There are 39 beef bones. Major cuts and the number of bones of each are small end sirloin (2), hip sirloin (8), chuck/rib (4), cross ribs/plate (8), leg (1), round (1) and 11 vertebrae fragments. This includes $1 \mathrm{~T}$-bone steak, 12 sirloin steaks and 1 round steak.

One lot of bones of mixed stratigraphy include 2 chickens. There are 31 beef bones. Major cuts and the number of bones of each are small end sirloin (3), hip sirloin (8), chuck/rib (5), cross ribs/plate (7), shoulder clod (1), brisket/navel (2), shin (2) and 3 vertebrae fragments.

\section{Vanderstratten Well}

Of the 5065 bones that were recovered from the well, 11 percent were burned and 97 percent of the burned bones are of beef and pork. In the first 8 levels 2 percent of the bones were burned while 16 percent were burned in the last 6 levels. The bone was comprised of 16.8 percent fish, 13.4 percent birds, 68.0 percent mammals and 0.1 percent amphibians (Table A-5).

Stratigraphy and artifacts in the well suggest it was filled rapidly, possibly in a single operation, in which trash from some other location was dumped down the well to fill it quickly once it was no longer a water source.
Four non-food vertebrates are toad, mockingbird, Norway rat and house cat. Eighteen non-domestic food vertebrates are catfish, largemouth bass, freshwater drum, carp, black drum, redfish, speckled trout, sheepshead, bullfrog, bobwhite, teal, mallard, Canada goose, mourning dove, opossum, cottontail, jack rabbit and white-tailed deer. Five domestic food vertebrates are pigeon, turkey, chicken, pig and cow. The artifact catalogue sheets include hunting material in 7 of the levels. Freshwater fishing trips may be indicated by shells in 3 levels and crawfish in 1 interval. Saltwater fishing trips may be indicated by oyster shells in 3 levels and stone crab chelae in one level.

Non-food animals in the first level include a Norway rat and 3 neonatal kittens. At least 1 redfish was butchered. A bobwhite is represented by one bone from the wing. Two white-tailed deer were butchered with the antlers of both being sawed away and not discarded. Other than bones from the heads, there are only three bones which are from the lumbar region.

At least one turkey was butchered. The neck and foot are the only parts represented. At least 7 chickens were butchered. The major cuts and the numbers of bones of each are breast (3), leg (12), back (11), wing (12), wingtip (4), head (3), shank (6) and foot (3). Apparently all that were butchered were eaten.

A total of 27 beef bones were recovered. Major cuts and the numbers of bones from each are small end sirloin (1), hip sirloin (3), chuck/rib (3), socket/rump (4), cross ribs/plate (8), shoulder clod (2) and miscellaneous ( 6 vertebrae fragments). This includes one T-bone and three sirloin steaks.

In the second level, 2 bass, 2 freshwater drums, 1 catfish, and 1 speckled trout were deposited as well as at least one other smaller unidentified fish. One cottontail and 1 jack rabbit were butchered. There is little indication that the fish and rabbits were consumed on the premises.

Two chickens ( 9 bones) weighing 4 and 5 pounds were eaten. Major cuts and the numbers of bones of each are breast (3), leg (1), back (2) and wing (3). Three pig bones indicate that some pork was consumed. These are a rib, a roast from the lower bone from the 
Table A-5. Faunal Remains from the Vanderstratten Well

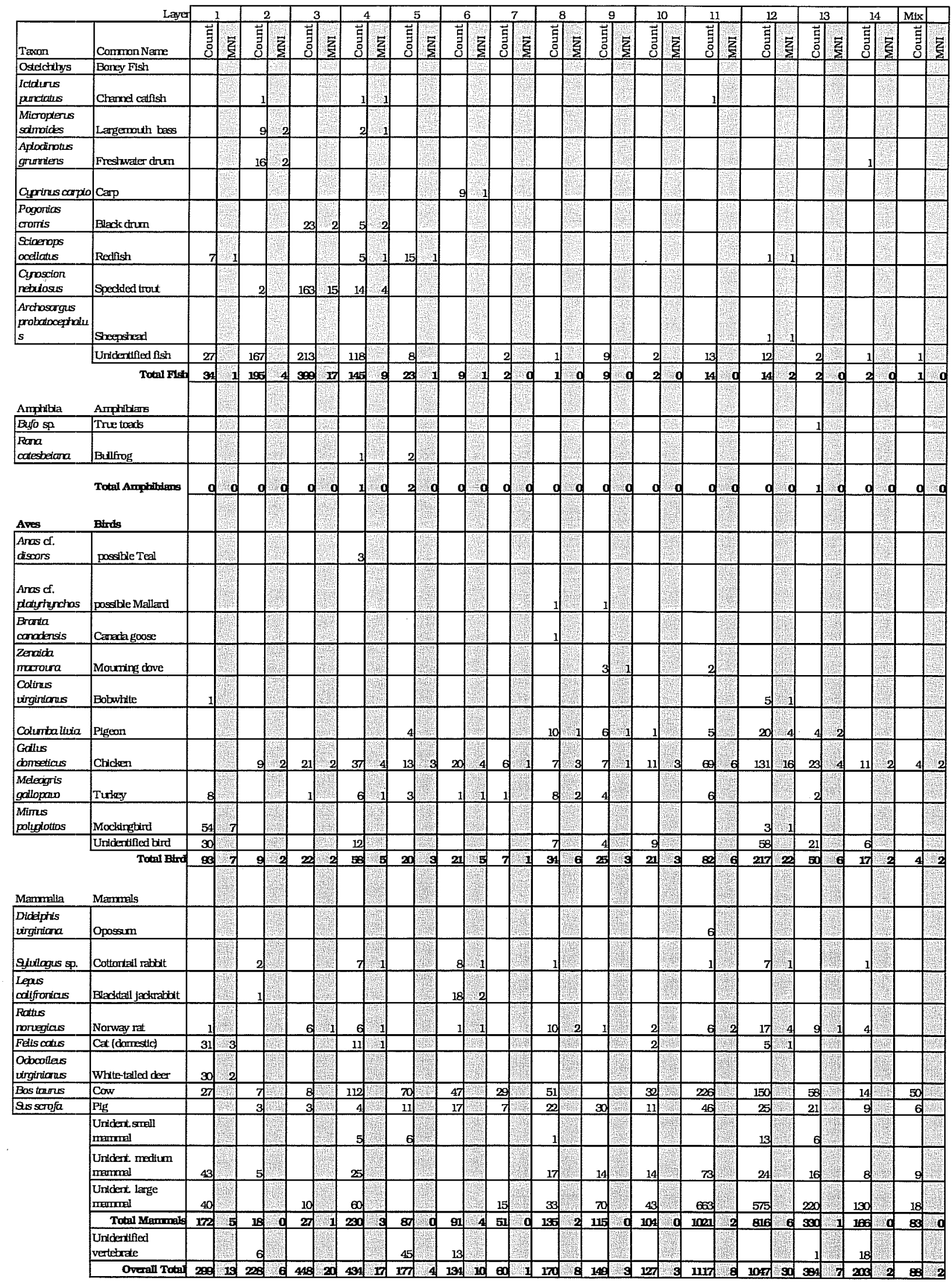


ham and a foot bone. Beef is represented by only 7 bones which are from round steaks.

Unidentified fragments (6) and unidentified medium mammals bones (5) could be from pig.

Deposits in the third level include 1 Norway rat. At least 17 fish were butchered with most of the discard parts being thrown into the well. This includes 2 black drum and 15 speckled trout. Unidentified fish remains include 210 bones and 3 scales. Only 10 vertebrae are included and two of these were large and had been cut at an angle as for fish steaks.

A small turkey is represented by a coracoid. Two chickens were processed and eaten. Major cuts and the numbers of bones of each are breast (1), leg (2),back (7), neck (5), wing (3), wingtip (1) and head (2). Only 3 pig bones are included. These are a round steak and 2 foot bones. Eight beef bones are included. The numbers of bones of the major cuts are socket/ rump (2), cross ribs/plate (5) and round (1). The only steak is from the round.

One Norway rat is represented in the fourth level. A neonatal house cat is represented by 11 bones.

Remains of at least 9 fish were thrown into the well. This includes 4 speckled trout, 2 black drum, 1 redfish, 1 largemouth bass, and 1 channel catfish. A bullfrog is represented by one vertebra. A teal is represented by 3 bones. A cottontail is represented by 7 bones. A small turkey is represented by 6 bones. Four chickens were processed and eaten. Major cuts and the numbers of bones of each are breast (4), leg (5), back (7), neck (4), wing (4), head (7), shank (1) and foot (5). Unidentified bird bones are probably all chicken.

Only 4 pig bones are included. These are from the lower ham andfoot bones. There are 124 beef bones included. The numbers of bones of the major cuts are small end sirloin (14), hip sirloin (3), chuck/rib (2), socket/rump (3), cross ribs/plate (50), brisket/navel (5), shin (10), round (4) and miscellaneous vertebrae fragments (32). This includes 13 T-bone, 2 sirloin and 4 round steaks.
Remains of one redfish were in the fifth level. A bullfrog is represented by two vertebrae. A young pigeon is represented by a humerus and 3 fragments. A small turkey is represented by bones of the leg, wing and back. Three chickens were processed, and eaten. Major cuts and the numbers of bone of each are breast (3), leg (5), back (1), wing (2) and foot (2). Pig is represented by ribs, pork chop, round steak, ham and foot bones.

There are 70 beef bones included. The numbers of bones of the major cuts are small end sirloin (11), hip sirloin (4), chuck/rib (4)y socket/rump (2), cross ribs/plate (26), shoulder clod (3), brisket/navel (1), shin (3), round (2) and miscellaneous vertebrae fragments (14). This includes $11 \mathrm{~T}$-bone, 4 sirloin and 2 round steaks.

A single bone of the Norway rat is included in deposits in the sixth level. A carp is represented by various bones from the anterior part of the body. A cottontail is represented by bones of the head and body. Two jack rabbits are represented by bones of the head and leg. A turkey is represented by a bone from the neck. Four chickenswere butchered and eaten. Major cuts and the number of bones of each are breast (1), leg (7), back (2), wing (9) and wingtip (1).

Pig is represented by ribs, 5 round steaks and foot bones. There are 47 beef bones. The numbers of bones of the major cuts are small end sirloin (10), hip sirloin (4), chuck/rib (1), cross ribs/plate (26), neck (1), shin (1) and round (4). This includes $10 \mathrm{~T}$-bone, 4 sirloin and 4 round steaks.

One leg bone of a turkey is included in the seventh interval. One chicken was butchered and eaten. Major cuts and the number of bones of each are leg (1), wing (4) and shank (1). Pig is represented by 2 round steaks and various bones of the foot. There are 29 beef bones included. The numbers of bones of the major cuts are small end sirloin (3), socket/rump (1), cross ribs/plate (18), brisket/ navel (1), round (2) and 4 miscellaneous vertebrae fragments. This includes $3 \mathrm{~T}$-bone and 2 round steaks.

Two Norway rats are represented in deposits of the eighth level. One bone each of unidentified fish, mallard, Canada goose and cottontail are included. One pigeon includes bones from all parts of the body. Two 
small turkeys are represented by bones of the wing, leg and foot. Three chickens are included. Major cuts and the number of bones of each are breast (1), leg (1), back (1), neck (1) and wing (3).

Pig is represented by one bone of the lower ham and various bones of the hind foot. There are 51 beef bones included. The numbers of bones of the major cuts are hip sirloin (2), chuck/rib (1), cross ribs/plate (37), round (4) and 7 miscellaneous vertebrae fragments.

A Norway rat is represented in the ninth level. Six fish bones were included but the species was not identified. One mallard bone and 3 dove bones are included. One pigeon is represented by bones of the head, wing and back.

A turkey is represented by bones of the neck and foot. One chicken is included. Major cuts and the number of bones of each are breast (3), leg (1), back (1) and wing (2).

Pigis represented by various bones of the ham and shoulder cuts with 70 percent of the numbers being discarded parts of the feet. At least 3 different pigs are indicated by the calcanei.

One Norway rat is represented in deposits of the tenth level. A young house cat is represented by 2 bones. Two bones of unidentified fish are included. One leg bone of a pigeon is present. Three chickens are included. Major cuts and the number of bones of each are breast (1), leg (7), back (1), wing (1) and shank (1).

A pig is represented by a bone of the lower shoulder cut and various bones of the foot. There are 33 beef bones included. The numbers of bones of the major cuts are small end sirloin (3), hip sirloin (2), chuck/ rib (3), socket/rump (2), cross ribs/plate (15), shoulder clod (1), shin (1), round (1) and 5 vertebrae fragments. This includes 1 round and 3 T-bone steaks.

Two Norway rats were recovered from the eleventh level. Fish bones consist of one of channel catfish and 13 of unidentified fish. This includes 7 vertebrae. A dove is represented by and a cottontail were present. An opossum is also represented.
A turkey is represented by bones of the breast, leg and wing. Six chickens are included. Major cuts and the number of bones of each are breast (11), leg (14), back (13), neck (5), wing (13), wingtip (2), head (3), shank (7) and foot (2). Two pigeons are represented by bones of the breast and leg. Three pigs were slaughtered and butchered with bones of the head, lower part of the shoulder cut, lower part of the ham cut and feet. There are 242 beef bones. The numbers of bones of the major cuts are small end sirloin (6), hip sirloin (15), chuck/rib (3), cross ribs/plate (157), shoulder clod (1), brisket/navel (17), shin (1), leg (1), round (10) and vertebrae fragments (31). This includes at least $6 \mathrm{~T}$-bone, 11 sirloin and 10 round steaks.

Four Norway rats are represented and a house cat were recovered from the twelfth level. Three bones of a mockingbird are included. Fish bones are one each of redfish and sheepshead with 12 unidentified bones. One bobwhite and one cottontail are indications of hunting activity.

Four pigeons apparently were eaten. Seventeen chickens were butchered and most apparently were eaten on the premises. Major cuts and the number of bones of each are breast (7), leg (14), back (21), neck (14), wing (18), wingtip (2), head (4), shank (24) and foot (27).

Pig are represented by one bone of the lower shoulder cut, two bones of the ham cut and several bones of the feet.

There are 150 beef bones. The numbers of bones of the major cuts are small end sirloin (1), hip sirloin (13), chuck/rib (5), cross ribs/plate (115), brisket/ navel (8), round (5) and vertebrae fragments (3). This includes $1 \mathrm{~T}$-bone, 1 sirloin and 5 round steaks.

The thirteenth level included 1 leg bone of a toad. A Norway rat and 1 cottontail are represented. Two pigeons are represented by bones of the lower leg. A turkey is represented by bones of the wing and foot. Four chickens were butchered and apparently were eaten. Major cuts and the number of bones of each are breast (2), leg (3), back (6), neck (3), wing (4), head (1) and shank (4). 
Pig bones include two bones of a ham cut with a tooth and various foot bones. Two sizes are represented.

There are 58 beef bones included. The numbers of bones of the major cuts are small end sirloin (1), hip sirloin (3), chuck/rib (1), cross ribs/plate (39), brisket/ navel (6), shin (2), round (5) and long bone (1). This includes 1 T-bone, 3 sirloin and 5 round steaks.

Fourteenth level deposits included 1Norway rat. One bone each from a freshwater drum and an unidentified fish are included. One leg bone of a cottontail is included.

Two chickens are present. Major cuts and the number of bones of each are breast (2), leg (2), neck (2), wing (4) and shank (2). The pig bones include 2 from a ham cut, 2 from the neck and others from the feet. The 14 beef bones include small end sirloin (1), hip sirloin (1), cross ribs/ plate (11) and vertebra (1). This includes $1 \mathrm{~T}$-bone and 1 sirloin steak.

Two lots of bones of mixed stratigraphy include chicken bones from the breast, leg, wing and shank. The 10 pig bones are of one ham cut and various discard parts of the feet. The 50 beef bones include 5 T-bone steaks, 3 round steaks, 39 ribs and one fragment of humerus, vertebra and unspecified long bone.

\section{Vanderstratten Yard}

In addition to the privy and well, bones were recovered in 18 excavation units in the Vanderstratten yard (Table A-6). This yielded 125 bones, none of which were burned. Amphibians comprise 0.8 percent, birds 10.4 percent and mammals 87.2 percent of the total.

The non-food item is a bone from a spadefoot toad. The non-domestic animal is a deer represented by one bone.

One turkey bone is from the wing. Ten chicken bones are from the breast (2), leg (5), neck (2) and foot (1). Pig bones are a rib and a foot bone. There are 28 beef bones. Major cuts and the number of bones are small end sirloin (2), hip sirloin (1), chuck/rib (7), cross ribs/ plate (9), shin (3), leg (1), round (4) and 1 vertebra fragment.

None of the excavation units in the yard yielded bones that had been burned. Thus if trash was burned on the premises, the excavations missed the location. Except for the bone of the spadefoot toad, all of the material is indicative of food consumption. The food items are mostly beef and chicken. The array of bones from the yard supports the contention that non-food animals and offal from butchering fish, game animals, poultry and some pigs was thrown directly into the privy or well rather than being dumped with the household garbage.

\section{Conclusions: The Vanderstratten Site}

Based on analysis of bones from the Vanderstratten privy, well and yard, the following conclusions appear to be tenable:

The occupants of the Vanderstratten property apparently threw household garbage out in the yard at

Table A-6. Faunal Remains from the Vanderstratten Yard

\begin{tabular}{|c|c|c|}
\hline Taxon & Common name & Count \\
\hline Amphibia & Amphibians & \\
\hline \multirow[t]{2}{*}{ Scaphiopus sp. } & Spadefoot toad & 1 \\
\hline & Total Amphibians & 1 \\
\hline Aves & Birds & \\
\hline Gallus domesticus & Chicken & 10 \\
\hline \multirow[t]{3}{*}{ Mealgris gallopavo } & Turkey & 1 \\
\hline & Unidentified bird & 2 \\
\hline & Total Birds & 13 \\
\hline Mammalia & Mammals & \\
\hline Odocoileus virginianus & Whitetailed Deer & 1 \\
\hline Bos taurus & Cow & 27 \\
\hline \multirow[t]{7}{*}{ Sus scrofa } & Pig & 2 \\
\hline & Unidentified srnall & 1 \\
\hline & Unidentified medium & 12 \\
\hline & Unidentified large & 66 \\
\hline & Total Mammals & 109 \\
\hline & Unidentified Vertebrate & 2 \\
\hline & Overall total & 125 \\
\hline
\end{tabular}


various places. Some, but not all, of the trash was burned at a location that was not excavated. The unburned and scorched residue was gathered and dumped into the privy and well. The frequency of such dumping has not been determined. The privy was filled earlier than the well.

The trash disposal practices were such that rats were plentiful. House cats were kept, perhaps as a control on the rat population. Dead rats and dead surplus cats were thrown into the privy and well as needed. In like manner the inedible parts of fish, fowl, game animals and the slaughtered animals were thrown into the privy and well as needed.

After the dumping started in the privy, within the hunting range of the cats there was enough undeveloped land to meet the environmental needs of the pocket gophers and spadefoot toads.

During the early part of the time of filling the privy, freshwater fish were being processed. During most of the time of filling the well, both freshwater and saltwater fish were being processed.

During the time of filling both the privy and well, hunting activity procured a few game birds, waterfowl and small mammals. During the filling of the privy a javelina and a deer were butchered. The earliest deposit in the well included two deer and the eleventh level included an opossum.

Pigeons were eaten during the early filling of the privy and in the later two-thirds of filling of the well. Turkeys and chickens were being butchered during all times of dumping in the privy and well. The actual number of butchered turkeys may be somewhat less than 30 and the number of butchered chickens may be less than 179 which are the minimum numbers of individuals if the bones in each deposition interval are considered as though there had been no mixing during disposal and recovery. However, turkeys and chickens were a major part of the food that was processed on the premises and there are indications that fewer of each were being eaten than were butchered. Estimated live weights of the chickens recovered from this site were made by the procedure described above and counts of the MNI for each weight are shown in Figure A-4.

At least one goat was butchered during the filling of the privy. The bones could all be from the same individual if they happened to be gathered from the primary dump site on three separate occasions.

Pork was consumed during all intervals. Cured ham was eaten early in the filling of the privy and perhaps not later. One pig was slaughtered during the early filling of the privy and three were slaughtered later in the filling of the well. Beef was consumed during the entire period of filling of the privy and well. The people apparently acquired larger cuts and did the final butchering on the premises. Sirloin and T-bone steaks were the preferred cuts during the filling of the privy. Ribs were the most common cuts during the filling of the well, although T-bone, sirloin and round steaks were eaten. Roast were apparently prepared during all intervals.

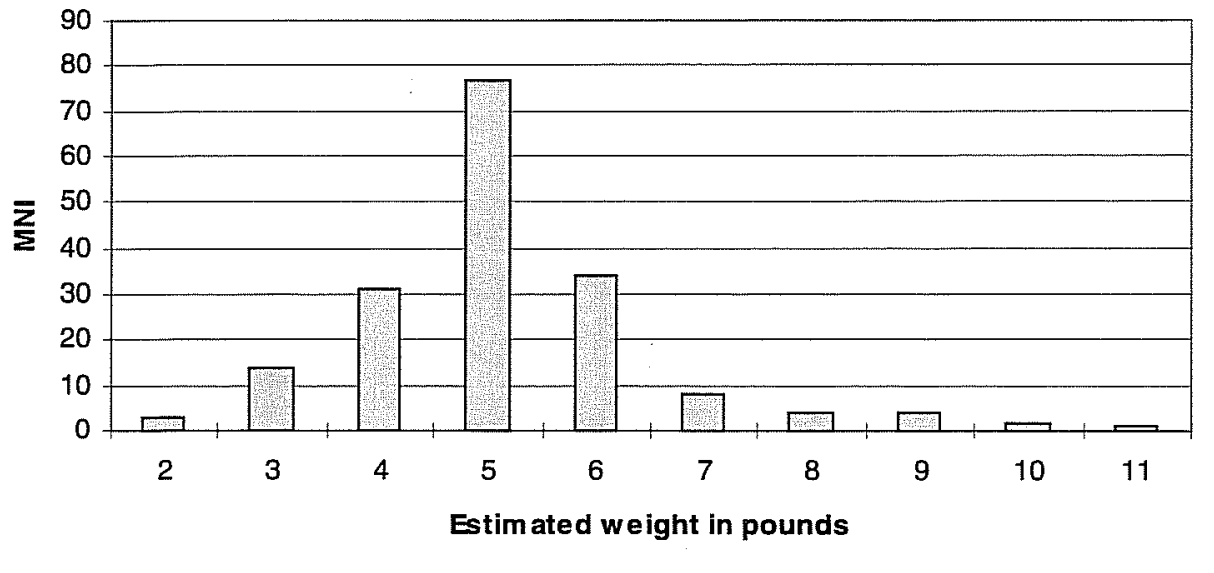

Figure A-4. Estimated live weights of chickens from the Vanderstratton Site.Note the total MNI for chickens from this site was 178 . 


\section{Discussion}

The Rivercenter deposits yielded bones of at least 43 species of vertebrates. Fourteen of these species are not considered to be food resources although most are technically edible. Wild, non-domestic vertebrates are represented by 23 species that apparently were used for food. The majority of the food resources used by the inhabitants were from 6 domestic varieties of vertebrates.

\section{Non-food Vertebrates}

Vertebrates included in this category are dog, cat, house mouse, Norway rat, two species of pocket gophers, woodrat (pack rat), mockingbird, oriole, cardinal, house sparrow, toad and spadefoot toad. The dog bones are from one litter of pups and one other. Since very few of the bones in any of the units have indications of having been gnawed by dogs, it is probable that few dogs were on the premises during the deposition episodes. The cat bones are from several different litters at all the homesites. This suggests that cats were common around the premises and that the residents controlled the cat population by killing the kittens. The cats may be responsible for the presence of the rodents and smaller birds in the refuse. It is common practice for cats to capture such small animals and 'present' them to their masters who then dispose of the victims.

The house mouse is probably under-represented in the collection, perhaps due to loss during screening or because the cats consumed them totally. Norway rats were numerous during all periods of deposition. Owls and hawks are not suspected as contributors to the deposits as the accumulations would not have been under appropriate roosts. The absence of black rats (Rattus rattus) from the deposits may reflect that the high population level of Norway rats excluded their smaller congeners from the neighborhood. The two species of pocket gophers and the pack rat are in very small numbers in the deposits and they are probable victims of the cats as well. However, their presence within the foraging range of the cats indicates that at the time of the deposits there must have been sufficient undeveloped land nearby to support these species.

Mockingbird, oriole, cardinal and house sparrow bones are in small numbers in the collection. These small birds probably were victims of the cats, although, at the end of the Nineteenth Century, song birds were sometimes available in local markets. Palmer (1900:286) indicated that "In the markets of New Orleans everything that has feathers seems to be regarded as legitimate game."

The toad and the spadefoot toad are in small numbers in the collection and their bones probably became included in the matrix through death by natural causes

\section{Food Items Non-domesticated Vertebrates}

The Rivercenter collection includes bones of 23 species of animals other than domesticates that apparently were used for food. Included in this category are channel catfish, bullhead, sunfish, largemouth bass, freshwater drum, carp, black drum, redfish, speckled trout, sheepshead, bullfrog, teal, wigeon, mallard, Canada goose, mourning dove, bobwhite, opossum, cottontail rabbit, jackrabbit, fox squirrel, white-tailed deer and javelina.

At the time of the deposits, channel catfish, bullhead, sunfish, largemouth bass, freshwater drum and carp probably were available in the San Antonio River as well as in other nearby waterways. Some of these fish may have been acquired in local markets. However, presence of some fishing tackle and fragments of a few chelae of crawfish (Cambaridae) within the collection indicates at least some local fishing trips probably were made.

The black drum, redfish, speckled trout and sheepshead are found in coastal waters, the nearest being Copano Bay which is 120 miles southeast of the site. Presence of numerous bones of the heads of these saltwater species suggests that the fish were brought to San Antonio fresh rather than salted or smoked. Their transport would have required ice, which was available commercially at that time. They 
may have been brought by rail which would have been via Houston. The presence in the deposits of a few fragments of marine molluscs and chelae of a probable stone crab (Menippe mercinaria) suggests that someone from the neighborhood visited the coast at least once on what may have been a fishing trip.

The deposits yielded very few fish vertebrae as compared to bones from the anterior part of the body. In an effort to evaluate the disparity, in 1986 a visit was made to a local fish market in Houston. In current practice, the market buys fish directly from local fishermen. At first, the fish are offered for sale whole. After an unspecified time, the unsold fish are filleted. The heads and attached bones are discarded. The fillets and backbones are then offered for sale separately. The backbones have a small amount of edible flesh and are sold at a reduced price to low-income people. Thus, heads would be included in the refuse at the homes of the buyers of whole fish and in the dump used by the fish market. The buyers of the fillets would have only ribs in their refuse and the buyers of the backbones would discard only vertebrae. Buyers of whole fish would have all of the bones in their refuse. If a cafe bought the fish, the refuse pattern could be similar to any of the above. An alternate solution would involve differential disposal practices within the household such as dumping the heads and feeding the bones to the cats. From the volume and variety of fish bones, it is probable that these residents were buying whole fish and were catching some of the varieties themselves.

Only three bullfrog bones are in the collection. The vertebrae probably were discarded after butchering one individual frog. The single incidence of bullfrog remains suggests that one was caught during a fishing trip and added to the menu.

Teals, wigeons, mallards and Canada geese are migratory through Bexar County and could have been shot by hunters during Autumn or Winter. Mourning doves and bobwhites are resident in Bexar County and could have been shot at any time of the year. Some of these birds could have been bought in local markets as market hunters were active along the coast at the time of some of the deposits. According to Palmer (1900: 268), "The number of birds killed for game in the United States has increased largely with the development of railway systems and the perfection of cold-storage facilities for shipping game to market." However, since these six species are in small numbers but in all of the homesites and shotgun shells are among the recovered artifacts, it is probable that they were acquired by the residents by hunting, probably nearby.

The opossum, fox squirrel, javelina and white-tailed deer are in relatively few numbers in the deposits and they probably represent hunting effort by the residents. At least two of the deer had their antlers sawed off before the bones were discarded. The cottontail rabbit and the jackrabbit bones are in the deposits in sufficient numbers to suggest that they were hunted on various occasions by the residents. Rifle cartridges within the recovered artifacts support this speculation. An alternative would be that local hunters were supplying the animals to the markets.

The prevalence of bones of wild animals throughout the deposits indicates that hunting and fishing efforts supplied a small but significant part of the diets of the residents.

\section{Food Items Domesticated Vertebrates}

The Rivercenter collection includes bones of six species of domesticated animals that were used for food. Included in this category are pigeons, turkeys, chickens, goats, cows and pigs.

The frequency and distribution of pigeon bones throughout the deposits as well as the age groups represented all support the conclusion that these birds were food items rather than fortuitous inclusions in the refuse. It is possible that some were feral birds and some may have been purchased in the local market. Perhaps some were killed by the ubiquitous cats. It has been observed on several occasions when pigeons were caught and eaten by cats, the only residue on the grounds consisted of feathers, wing tips, feet and sometimes skulls. This is not the array of bones in the deposits. There is no apparent indication of 
propagation of pigeons on the premises but they must have been readily available.

The turkeys in the collection are considered to be domestic rather than wild varieties. One or more of the turkeys may have been shot in the wild as the artifacts include evidence of hunting activity. However, the composition of the assemblage of turkey bones supports the conclusion that these are domestic varieties. For example, 10 skulls were included in one deposition interval. Most of the skulls had been impacted in the occipital area by the axe when the birds were butchered. It is unlikely that a hunter would have shot 10 adult wild birds on one hunting trip. In addition, the family probably would not have butchered 10 turkeys at one time for home consumption. It is noteworthy that more turkeys were butchered than were eaten on the premises. Because of the small lot sizes in the subdivision, it would have been difficult for that many turkeys to have been raised there. Perhaps one of the occupants operated a poultry farm at a remote location and brought live turkeys to the site to be butchered for sale to a market or to a cafe or to the neighbors.

As was the case with turkeys, many more chickens were butchered than were eaten on the premises. Broken glass artificial eggs were recovered in the deposits indicating that some chickens probably were raised at one of the homesites. It is unlikely that all of the chickens that were butchered could have been raised on the small homesites which suggests that some chickens were acquired from a remote poultry farm as was the case with the turkeys.

A few goat bones are included in the collection. Perhaps some of the unidentified materials may be of the same species. It is possible that all of the goat bones are from the same individual. Apparently, goat meat was not a common part of the diet in the com-munity. The absence of sheep bones also suggests that mutton was not on the menu.

More than 300 pork bones are in the collection. This number would be nearer 800 if most of the unidentified medium-sized mammals are pig, as is suspected. Some of the pigs may have been slaughtered on the site as mandibles, teeth and foot bones are included. More than 200 bones are from feet and consist of carpals, tarsals, metacarpals, metatarsals and phalanges. This includes the toe bones that are discarded in preparation of pickled pigs feet. Bones are included that would be from all major cuts. Some of the pork may have been purchased at the market as these standard cuts and then further processed at the homesites. At least some of the vertebrae were sawed longitudinally as would have been done at the market or by knowledgeable home butchers. Irregular thickness of cuts of steaks and chops suggests that some of the butchering was done by other than a professional butcher. Ribs, roasts, round steaks, pork chops, shoulder steaks and rump steaks are all represented. One deposition interval includes a tibia, a femur and an innominate that articulate with each other indicating that the entire hind leg was discarded. Perhaps this was a cured ham that did not need to be consumed at one meal. Some of the round steak bones are so thin that they must have been from cured ham as fresh pork would be impractical to cut and serve at that thickness. Thus, it is possible that the people in the block were slaughtering pigs as well as buying fresh pork and cured ham.

The collection includes numerous bones of unidentified medium-sized mammals. These represent roasts, chops, round steaks, ribs, fragments of vertebrae, a few shoulder steaks and a few rump steaks. It is probable that most of these are pig bones.

Nearly 2500 beef bones are in the collection as well as about 4500 other fragments that are probably beef. Cranial parts, atlas, metacarpals, metatarsals and phalanges are absent, indicating that cattle were not being slaughtered on the premises. The residents may have been buying either sides or quarters of beef or one of the standard butcher cuts. Bones are included from all the standard meat cuts which contain bone. The axis has hack marks on it that indicate that it was severed from the atlas in a rather rough manner. The vertebrae were severed longitudinally either by saw or cleaver. Vertebrae with only a single cross cut or none suggest that the cuts were used as bought for roasts. Vertebrae with two parallel cross cuts indicate that some of the cuts were further reduced for steaks. The irregularity of these cuts as well as of steaks cut from the chuck and round suggests that many of the steaks were cut by other than professional butchers. 
Round steaks were cut from the humerus and tibia but most of them were from the femur. Ribs have hack marks as well as saw cuts that indicate that they were also reduced from the larger cuts for consumption. Cuts at leg joints probably were for soup preparation.

\section{Neighborhood Overview}

At the time of the early deposits, some nearby locations were undeveloped and supported small native animals thatare no longer found in the neighborhood. Poor sanitary conditions are indicated by the high population level of commensal rats. House cats were plentiful and probably served as controls of the rat population. The cats probably also took a few other rodents and small birds. Few dogs were kept by the residents.

Some of the residents went fishing in inland as well as coastal waters. Some went hunting for waterfowl, game birds, small game mammals and deer. Some of the wild animals and fish may have been acquired from the market but presence of heads, wings and feet suggests that most of the hunting and fishing was by individual family members for home consumption.

Enough pigeons were included in the refuse to indicate that they often were consumed. Some chickens were raised on the premises but numerous chickens and turkeys apparently were brought from remote locations and were butchered in the yards. Many more of these domestic fowl were butchered than were consumed which suggests that the residents may have been supplying a local eating establishment or market.

At least one goat was butchered in the neighborhood but that animal was not a common part of the diet of the families. Sheep were not represented at all. Pork was a common part of the diet of the families. Pigs may have been slaughtered at the site or whole pigs may have been brought in for butchering. Some of the pork was cured as ham while some was consumed while fresh. All parts of the pig were used. Beef was a major part of the diet. No cattle were slaughtered at the site but reduction of major cuts of beef into smaller units was accomplished by the residents. All meatbearing elements of the cow were included.

\section{References Cited}

Howard, G. E.

1897 Standard Varieties of Chickens. Farmer's Bulletin No. 51, Bureau of Animal Industry, U.S. Department of Agriculture, Government Printing Office, Washington, D.C.

Palmer, T. S.

1900 A Review of Economic Ornithology in the United States. In 1899 Yearbook of The United States Department of Agriculture. Government Printing Office, Washington. 


\section{Appendix B: Local Druggists}

Alamo Drug Store

Appman, William

Appmann \& Serger

Aransas Pass Drug Store

Batelle Bros.

Belcia, C.E.

Bernstein

Bexar County Drug

Blair, Henry

Bodemann, J.U.

Booker, E.M.

Bristow, B.W.

Burke, J.A.

Burns, W.C.

Campbell, Car

Canaman, I.

Central Drug Store

Chapa \& Driess

Chapa, F.A.

City Drug Co.

City Drug Store

Clavin, William R.

Clavin, James

Cohn, R. \& Co.

College

Colwell, F.C.

Commercial

Crescent Pharmacy

Crossley

Cunningham's Drug Store

Cupples Drug Co.

D'Albini, William

D'Albini, Wm. \& Co.

Devine, James

Diaz, F.Z. \& Co.

Donoho, H.M.

Dowling \& Flood

Dowling, J.W.

Downey, J.W.

Dreiss, Adolph

Duncan, T.B.

Eagle Pharmacy

Elbe, C.B.

Elbers \& Landy

Elliot \& Ragland
1907-09

1892-1909

1907-09

1891-96, 1905-09

1883-84

1897-1900

1905-06

1903-10+

1885-1906

$1887-91$

1895-1900

1895-96

1900-02

$$
\text { 1907-10+ }
$$

1892-98

1901-04, 1910+

1895-96

1899-1904

1905-10+

1903-10+

1891-96

1883-90

1877-82, 1891-1906

1883-1910+

$1910+$

1891

1909

$1892-95$

1908-09

1891

1907-10+

1887-93

1895-1902

$1887-88$

1895-1910+

1907-08

$1881-96$

1903-04

1891

1877-1906

1891, 1903-04

1899-1900

$1879-80$

1883-84

1883-84
Ernest, I.W. (India Drug)

Farmer's Drug Store

Faubian

Fegan

Fischer, A.M.

Fischer \& Davis

Fischer \& Springall

Fischer, J.D.

Gallagher

Government Hill

Guerra

Harrison, J.T.

Herff \& Wilding

Hervey \& Macdonald

Hogue, Elton

Houck, F.A.

Huppertz, Herman J.

I \& G.N. Drugs

International Drug Store

Itschener

James, W.F.

Jones \& Virden

Jones, Joseph $\mathrm{H}$.

Jungkind \& Fischer

Jungkind, E.

Kalteyer, Frederic

Kalteyer, F. \& Son

Kalteyer \& Schuchard

Kalteyer, W.C.

King \& McClintock

Koch, J.G.

Landry, J. Omer

Laurel Heights Pharmacy

Lee, L.R.

Lockert, R.H.

Lone Star

Martinez, $\mathrm{H}$.

McDaniel

McLerdom \& Wilson

Meirer's

Meissner's west End

Meyer Bros. Drug Co.

Michael, P.
1889-90

1891-93, 1907-10+

1909-10+

1905-06

1907-10+

1901-04

1905-06

1908

$1910+$

1907-10+

$1910+$

1892-93

1907-10+

1883-84

1891

1901-10+

1877-84

1905-09

1899-1910+

$1910+$

1895-1900

1895-1906

1887-88

1899-1900

1892-93, 1895-98,

1901-10+

1877-78

1879-91, 1895-

$1910+$

1892-93

1899-1910+

$1910+$

1892-93

1885-86

1909-10+

1892-93, 1895-96

1887-88

1903-10+

1891

1907-08

1891

$1910+$

1892-93

$1910+$

1909-10+ 


\begin{tabular}{|c|c|c|c|c|}
\hline Milam Square Drug Store & 1899-1904 & Spellessy, C. & 1889-90 & \\
\hline Milburn \& Alexander & $1899-1900$ & Spellessy, Thomas J. & $1891-92,18$ & 5-1906, \\
\hline Milburn Bros. & $1900-10+$ & & $1910+$ & \\
\hline Miller, Mrs. Henry W. & $1892-1900$ & Stein, P.S. & $1891-98$ & \\
\hline Miller, Henry W. & 1891 & Storey & $1910+$ & \\
\hline Miller, Fannie & $1899-1900$ & Sunset Drug Store & 1891,1903 & \\
\hline Mission Drug Store & $1891,1899-1910+$ & Swearingen Drug Co. & $1901-02$ & \\
\hline Nester & $1903-10+$ & Taliaferro, J.W. & $1897-1910+$ & \\
\hline Nette, August (Jr.) & $1877-78$ & Tip \& Siverthorn & 1891 & \\
\hline Nette, August (Sr.) & $1877-78,1881-91$ & Trevino & $1910+$ & \\
\hline Nette \& Son & $1877-78$ & \multirow{2}{*}{\multicolumn{2}{|c|}{$\begin{array}{l}\text { Twentieth Century Pharmacy (No. 1) } \\
\text { Twentieth Century Pharmacy (No. 2) }\end{array}$}} & $1910+$ \\
\hline Orynski, L. & $1881-82,1885-86$ & & & $1910+$ \\
\hline & $1889-91$ & Union Pharmacy & $1910+$ & \\
\hline Orynski \& Bro. & $1883-84$ & Voelcker, R.F. (Central) & $1889-90$ & \\
\hline Orynski \& Co. & $1887-88$ & Wagner & $1903-10+$ & \\
\hline Owl Drug Store & $1910+$ & Walsh, J.M. & $1895-1908$ & \\
\hline Patrick Bros. & 1899-1902 & West End & $1910+$ & \\
\hline People's Drug Store & $1903-10+$ & Wetzstein, E.B. & $1883-84$ & \\
\hline Petty, J.M. & 1897-98 & Wetzstein, Mrs. E.B. & $1885-86$ & \\
\hline Pfeiffer, J. & $1897-1908$ & Wheatley Bros & $1887-88$ & \\
\hline Post Office Drug Store & $1892-93,1895-96$ & Willey, John A. & $1892-93$ & \\
\hline Prospect Hill & 1908 & Yarbrough \& Giles & 1891 & \\
\hline Raglan \& Co. & $1885-88$ & Yarbrough \& Son & $1889-90$ & \\
\hline Raglan \& Schachner & 1889-90 & Young, N.C. & $1895-98$ & \\
\hline Red Cross & $1907-10+$ & & & \\
\hline Reid & $1905-08$ & & & \\
\hline Reuss, E.W. & $1892-1904$ & & & \\
\hline Rewand, J.R. & $1901-04$ & & & \\
\hline Rice Bros. & $1885-86$ & & & \\
\hline Saenz & $1907-08,1910+$ & & & \\
\hline Samuels & $1905-08$ & & & \\
\hline San Pedro & $1910+$ & & & \\
\hline San Pedro Drug Co. & $1892-1910+$ & & & \\
\hline San Pedro Drug Store & 1891 & & & \\
\hline San Pedro Pharmacy & 1891 & & & \\
\hline SAP Drug Store & $1910+$ & & & \\
\hline Sarro, Joseph & 1892-93 & & & \\
\hline Schasse, Conrad & $1877-1906$ & & & \\
\hline Scheff, William & $1877-78$ & & & \\
\hline Scheh, C.A. & $1910+$ & & & \\
\hline Schuchard, H. & $1889-92,1895-1910$ & & & \\
\hline Schultze & $1903-09$ & & & \\
\hline Schweppe, August & $1891,1895-1906$ & & & \\
\hline Siverthorn \& Waynell & $1895-96$ & & & \\
\hline Smith, Mrs. R.B. & $1892-93$ & & & \\
\hline South Flores St. Drug Store & $1910+$ & & & \\
\hline Southern Hotel Plaza Drugs & $1903-06$ & & & \\
\hline Southern Drug Store & $1907-08,1910+$ & & & \\
\hline Spahn, Louis & $1892-93$ & & & \\
\hline
\end{tabular}




\title{
Appendix C: Snails
}

An Early Urban Record of Opeas pyrgula in San Antonio, Texas

\author{
Raymond W. Neck \\ Texas Parks and Wildlife Department \\ 4200 Smith School Road \\ Austin, Texas 78744
}

Although numerous records of introduced snails are known from the United States (Hanna 1966; Dundee 1974), malacologists seldom are able to determine the exact time of introduction. Populations of adventive species may exist, and even thrive, for many years or decades before discovery by malacologists. Time of introduction of a particular population can be estimated by discussions with local residents or, occasionally, by examination of shells in dated collection lots. One other method, rarely utilized, involves the recovery of specimens from dated sediments.

Shells presented to this author were recovered from an historical archeological site in San Antonio (41BX634). Shells were extracted from lot IV-A-13 of the Vanderstratten Well. These specimens represent three adult shells of the Sharp awl snail, Opeas pyrgula Schmacker and Boettger, 1891. This species is native to Japan and China (Pilsbry, 1946). The three Vanderstratten Well samples measure 5.95, 5.8, and $4.95 \mathrm{~mm}$ in height.

Initial records of 0 . pyrgula from the United States (Pilsbry, 1946:183) were from decayed fence boards in Philadelphia in 1917 by E. G. Vanatta; under leaves in a park in Savannah, Georgia, in 1923 by James B. Clark; and Norfolk, Virginia, in 1944 by Leslie Hubricht. Dundee (1971) reported no additional localities. Subsequently, populations have been reported from Alabama (Hubricht, 1965), North Carolina (Hubricht, 1970), Maryland and District of Columbia (Grimm, 1971), Virginia (Hubricht, 1971; Beetle, 1973), Tennessee (Hubricht, 1973), and Texas (Fullington and Pratt, 1974). Dundee (1974) added localities in Florida, Louisiana, and Mississippi.
Texas records of Opeas pyrgula are very limited but likely underrepresent the actual occurrence of established populations. Initial Texas record was from Houston in 1958 (McGee, 1965). Dundee (1974) reported a population in San Antonio based on a personal communication from Harold S. Finberg. Fullington and Pratt (1974) added Dallas and Neck $(1976,1977)$ reported populations in Austin.

Opeas pyrgula is a member of the family Subulinidae which naturally ranges through semitropical and tropical areas of the world (Pilsbry, 1946). Essentially nothing has been published concerning the ecology of 0 . pyrgula, but some inferences may be drawn from observations on related species which have also become established at various localities in the United States. Karlin (1956) reported that greenhouse populations of Opeas pumilum (Pfeiffer, 1840) in New York were larger in beds with corn cob mulch than in beds with manure or straw mulch and those with no mulch. This distribution pattern indicates a susceptibility to desiccation.

Dundee (1970) reported observations on another achatinid snail, Lamellaxis gracilis (Hutton, 1834) in New Orleans. This species requires cover and descends into the soil with the onset of cool weather. Animals were found $7.6 \mathrm{~cm}$ below the surface during cold weather with an air temperature of $-5^{\prime} \mathrm{C}$. Snails remained below the surface during rains in the cool season. Horizontal movement in lawn areas were usually restricted to a home range with a diameter of 3 meters. Snails were not observed to climb.

Origin of North American populations of Opeas pyrgula undoubtedly involves transport in soil attached 
to roots of ornamental plants. Four species of Opeas (but not 0 . pyrgula) have been reported from European greenhouses (Meeuse and Hubert, 1949). Several of the introduced subulinid snails known from greenhouses in the northeastern United States are sufficiently common to damage petals of orchids and other flowers (Emerson and Jacobson 1976:229).

The origin of the San Antonio population of Opeas pyrgula also probably involves ornamental plants. Level IV-A-13 has been dated to the period between 1877 and 1897 by bottle remains in the deposit (Wayne Cox, personal communication). Levels 9,) 10 and 11 (above 13) contained fragments of flower pots (W. L. McClure, in litt.). 0. pyrgula could have burrowed down into level 13 from upper levels, but the origin of this population probably still dates to the latest nineteenth or earliest twentieth century. The surface layers of the Vanderstratten Well have been dated about 1910 (Wayne Cox, personal communication).

\section{References Cited}

Beetle, Dorothy E.

1973 A checklist of the land and freshwater mollusks of Virginia. Sterkiana 49:21-35.

Dundee, Dee Saunders.

1970 Introduced Gulf Coast Molluscs. Tulane Studies in Zoology and Botany 16:101-115.

1971 Subulinids and Veronicellids on the United States. The Biologist 53:128-132.

1974 Catalog of Introduced mollusks of Eastern North America (North of Mexico). Sterkiana 55:1-37.

Emerson, William K. and Morris K. Jacobson.

1976 The American Museum of Natural History Guide to Shells. Land, Freshwater, and Marine, from Nova Scotia to Florida. Alfred A. Knopf, New York, 482 pp.
Fullington, Richard W. and William Lloyd Pratt, Jr.

1974 The Helicinidae, Carychiidae, Achatinidae, Bradybaenidae, Bulimulidae, Cionellidae, Haplotrematidae, Helicidae, Oreohelicidae, Spiraxidae, Streptaxidae, Strobilopsidae, Thysanophoridae, Valloniidae (Gastropoda) in Texas. Bulletin of the Dallas Museum of Natural History 1(3):I-48.

Grimm, F. Wayne.

1971 Annotated Checklist of the Land Snails of Maryland and District of Columbia. Sterkiana 41:51-57.

Hanna, G. Dallas.

1966 Introduced Mollusks of Western North America. Occasional Papers of the California Academy of Sciences 48:1-108.

Hubricht, Leslie.

1965 The Land Snails of Alabama. Sterkiana 17:1-5.

1970 The Land Snails of North Carolina. Sterkiana 39:11-15.

1971 The Land Snails of Virginia. Sterkiana 42:41-45.

Karlin, Edward J.

1956 Notes on the ecology of Zonitoides arboreus (Say), Opeas pumilum (Pfeiffer), and Lamellaxis ilis (Hutton) in greenhouses. American Midland Naturalist 55:121-i25.

McGee, Paul L.

1965 Distribution and Ecology of the Terrestrial Mollusks of the Texas Coastal Counties. Master's thesis, University of Houston, Houston, Texas.

Meeuse, A. D. J. and B. Hubert.

1949 The Mollusc Fauna of Glasshouses in the Netherlands. Basteria 13:1-30. 
Neck, Raymond W.

1976 Preliminary checklist of land snails of Travis County. In A Bird Finding and Naturalist's Guide for the Austin, Texas, Area, edited by E. A. Kutac and S. C. Caran, pp. 124-129. Oasis Press, Austin, Texas.

1977 Introduced Land Snails of Travis County, Texas: Occurrence and success. The Nautilus 91:140-143.

Pilsbry, Henry A.

1946 Land Mollusca of North America (North of Mexico). Volume II. Part 1. Academy of Natural Sciences of Philadelphia. Monograph 3. 


\section{Appendix D: Skeletal Remains from the Funeral Pyre Area}

\section{David M. Glassman, Ph.D.}

Visual observation was made of the 847 recovered skeletal remains recovered from the Funeral Pyre area of the Las Tiendas project. Each was inspected for diagnostic attributes for classifying the remain as representing either human or nonhuman. Of the 847 remains, 314 were found identifiable relative to this criterion. None of these 314 remains were human. It is resonable to make the assumption that if human representation was present among the skeletal material recovered from the Las Tiendas' excavations, at least a few associative diagnostic remains would have been observed. Nevertheless, the possibility that one or more of the 533 indeterminate bones might belong to a human can not be totally ruled out.

In the attached table, the recovered skeletal remains have been broken down by provenience and the frequency of identifiable bones. Under the material category, numbers in parentheses represent the number of bone elements listed on the provenience label when inconsistency was encountered between my count and that of the label. 


\section{Las Tiendas Project Skeletal Material}

\begin{tabular}{|c|c|c|c|}
\hline Provenience & Material & Non-human & Indeterminate \\
\hline 2 & 2 & 2 & \\
\hline 3 & 3 & & 2 \\
\hline 8 & 3 & & 3 \\
\hline 9 & 3 & 2 & 1 \\
\hline 10 & 8 & 2 & 6 \\
\hline 11 & $5(3)$ & 2 & 3 \\
\hline 12 & 26 & 3 & 23 \\
\hline 13 & 35 & 2 & 33 \\
\hline 14 & 15 & 6 & 9 \\
\hline 15 & 12 & 1 & 11 \\
\hline 16 & 1 & 1 & \\
\hline 17 & 27 & 5 & 22 \\
\hline 18 & $24(26)$ & 11 & 13 \\
\hline 19 & 3 & 1 & 2 \\
\hline 20 & $8(10)$ & 2 & $\overline{6}$ \\
\hline 21 & 9 & 1 & 8 \\
\hline 25 & $12(13)$ & 5 & 7 \\
\hline 26 & 8 & 1 & 7 \\
\hline 27 & 20 & 1 & 19 \\
\hline 28 & $38(37)$ & 16 & 22 \\
\hline 30 & 39 & 3 & 36 \\
\hline 31 & $29(30)$ & 4 & 25 \\
\hline 32 & 4 & - & 4 \\
\hline 33 & $16(15)$ & 4 & 12 \\
\hline 34 & 4 & - & 4 \\
\hline 36 & 1 & & 1 \\
\hline 37 & 4 & - & 4 \\
\hline 38 & 10 & 3 & 7 \\
\hline 39 & 31 & 24 & 7 \\
\hline 40 & $124(122)$ & 54 & 70 \\
\hline 41 & 21 & 11 & 10 \\
\hline 42 & $3(4)$ & 2 & 1 \\
\hline 43 & 1 & 1 & \\
\hline 44 & 4 & 3 & 1 \\
\hline 45 & 13 & 12 & 1 \\
\hline 46 & 84 & 41 & 43 \\
\hline 47 & 2 & 1 & 1 \\
\hline 48 & 3 & 1 & 2 \\
\hline 49 & 13 & 1 & 12 \\
\hline 50 & 8 & 2 & 6 \\
\hline 51 & 11 & 3 & 8 \\
\hline 52 & 4 & 3 & 1 \\
\hline 53 & 46 & 29 & 17 \\
\hline 55 & $5(4)$ & 3 & 2 \\
\hline \multirow{3}{*}{$\begin{array}{l}56 \\
57\end{array}$} & $74(70)$ & 35 & 39 \\
\hline & $31(30)$ & 9 & 22 \\
\hline & 847 & 314 & 533 \\
\hline
\end{tabular}




\section{Las Tiendas Project Skeletal Material (not included in memorandum of May 9, 1985)}

I have now completed examining the "additional" skeletal material from the Las Tiendas project for the presence of human remains. Enclosed is a listing of the material in similar format to the list provided you on 5/9/85. No human remains were identified among the new 245 bone fragments. Also, after re-examining the metacarpals, metatarsals and phalanges from the first group, it does not appear that any are human as I previously thought perhaps possible. Please note that skeletal material from provenience \#56 is found on both lists and represents independent samples.

Provenience

22
53
56
59
60
61
62
63
64
65
66
67
68
69
70
71
Material

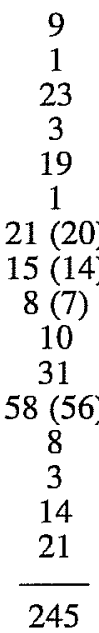

Human

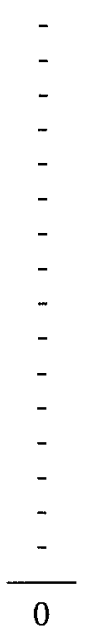

Non-human

Indeterminate

\begin{tabular}{c}
2 \\
1 \\
5 \\
- \\
2 \\
- \\
11 \\
3 \\
- \\
4 \\
4 \\
23 \\
3 \\
3 \\
7 \\
5 \\
\hline 73
\end{tabular}

7

$-$

3

17

1

10

12

8

6

27

35

5

7

16

172 